\title{
STATISTICAL AND NUMERICAL ANALYSES OF PRESSUREMETER TESTS IN GLACIAL TILLS
}

\author{
by \\ Kanagaratnam Balachandran, \\ B.Eng. (Hons), University of Moratuwa, 1997 \\ M.Eng, University of Moratuwa, 2009
}

\author{
A thesis \\ presented to Ryerson University \\ in partial fulfillment of the \\ requirements for the degree of \\ Master of Applied Science \\ in the program of \\ Civil Engineering
}

Toronto, Ontario, Canada, 2016

(C) (Kanagaratnam Balachandran) 2016 


\section{AUTHOR'S DECLARATION}

I hereby declare that I am the sole author of this thesis. This is a true copy of the thesis, including any required final revisions, as accepted by my examiners.

I authorize the Ryerson University to lend this thesis to other institutions or individuals for the purpose of scholarly research.

I further authorize the Ryerson University to reproduce this thesis by photocopying or by other

means, in total or in part, at the request of other institutions or individuals for the purpose of scholarly research. 


\title{
STATISTICAL AND NUMERICAL ANALYSES OF PRESSUREMETER TESTS IN GLACIAL TILLS
}

\author{
Kanagaratnam Balachandran \\ Master of Applied Science, 2016 \\ Department of Civil Engineering \\ Ryerson University, Toronto, Canada
}

\begin{abstract}
This study is performed on pressuremeter tests (PMT) in glacial tills based on comprehensive geotechnical investigation programs for a light rail transit project in the City of Toronto. The main objectives are to establish a correlation between SPT-N values and PMT parameters, and the Menard " $\alpha$ " factors for glacial tills. Currently, there are no such relationships available. So first, the pairs of PMT data and SPT-N values are collected at the same depth and test area. With these paired data, two linear correlation equations are established. Then, the numerical simulation is performed for PMTs in glacial tills by using finite element software, Plaxis 2D. The Mohr-Coulomb material model is used to model the different types of soil. The Menard " $\alpha$ " factor is suggested based on the best match between numerical prediction and field PMT. Ranges of SPT-N, $\mathrm{E}_{\mathrm{PMT}}$ and $\mathrm{P}_{\mathrm{L}}$ are also suggested for glacial tills.
\end{abstract}




\section{ACKNOWLEDGEMENTS}

This thesis arose in part out of years of research. In that time, I worked with several people whose contributions to the research and the making of the thesis deserve special mention. It is a pleasure to convey my gratitude to them in this humble acknowledgement.

In the first place I would like to record my sincere thanks and gratitude to Dr.Jinyuan Liu for his supervision, advice and guidance from the very early stage of this research as well as giving me extraordinary experiences throughout the work. Above all and the most needed, he provided me encouragement and support in various ways. His truly engineering intuition has made him as a constant oasis of ideas and passion in geotechnical engineering, which exceptionally inspired and enriched my growth as a student, a researcher and geotechnical engineer want to be.

In the second place I would like to record my sincere thanks and gratitude to Dr. Laifa Cao for his supervision. He provided a continuous source of ideas relating to the technical approach, numerical modelling, and the practical applications of the research.

Many thanks go to the Dean, Faculty of Engineering, Head of the Department of Civil Engineering and Dr A.El-Rabbany Professor and Graduate Program Director, Civil Engineering Program, for making all the necessary arrangements to carry out the project.

I would like to thanks Rachel Harpley, Graduate Program Administrator, Department of Civil Engineering, for her continuous communication and support during this study.

I must also thank the Department of Civil Engineering and Natural Sciences and Engineering Research Council of Canada for financial assistance and Metrolinx and SPL Consultant Limited for granting permission to study the ECLRT project data. 
It is a pleasure to pay tribute to the academic staff during the course studying stage for helping me in various ways for the successful completion of this thesis.

I would like to give sincere thanks to my wife and my children for their endless love, encouragements and patience throughout my educational career. 


\section{TABLE OF CONTENTS}

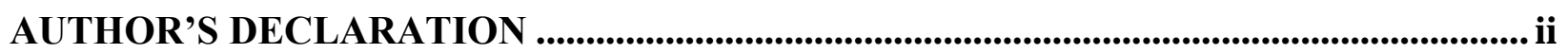

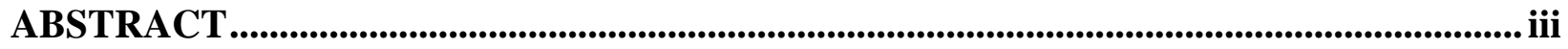

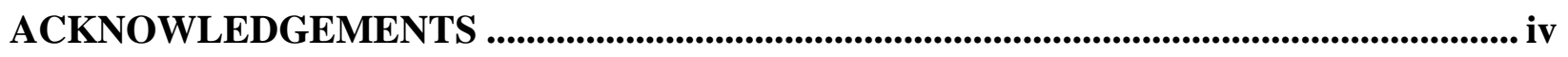

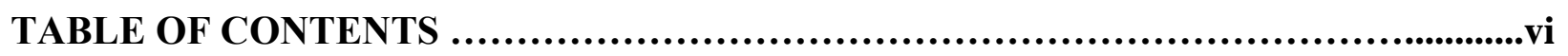

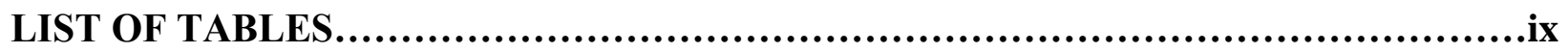

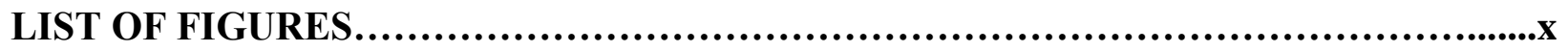

CHAPTER 1: INTRODUCTION........................................................................................... 1

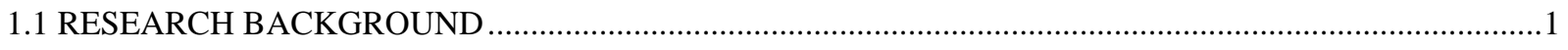

1.2 ENGINEERING BACKGROUND ....................................................................................................

1.3 NEED FOR RESEARCH............................................................................................................

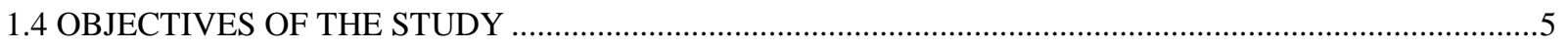

1.5 RESEARCH METHODOLOGY ………………………………………………………………..

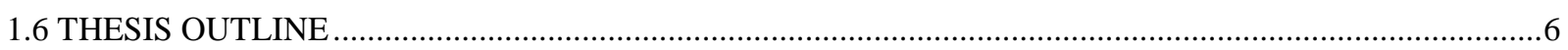

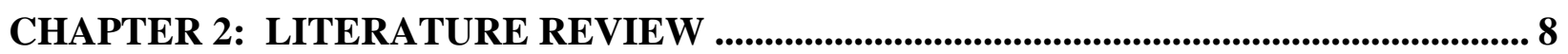

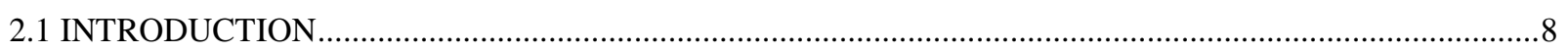

2.2 PREVIOUS RESEARCH ON STATISTICAL CORRELATION BETWEEN SPT AND PMT ........................8

2.2.1 STANDARD PENETRATION TEST (SPT) ………………………………………………...

2.2.1.1 Equipment and Test Procedure ……………………………………………………..

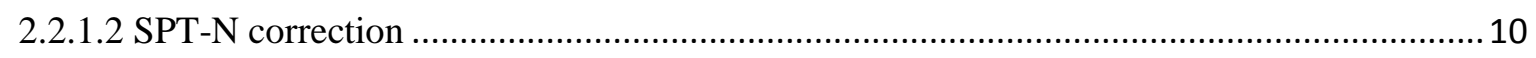

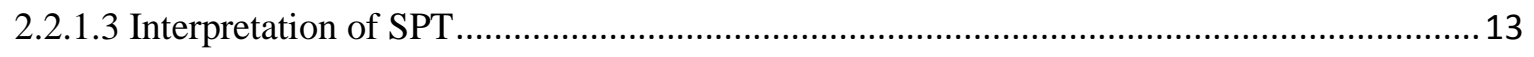

2.2.2 PRESSUREMETER TEST (PMT) ……………………………………………………….......13

2.2.2.1 Equipment and Test Procedure ………………………………………………….... 14

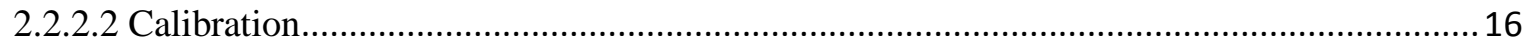

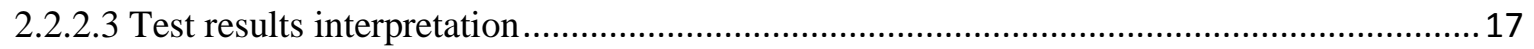

2.2.2.4 Application of these two parameters ........................................................................2 20

2.2.2.5 Pressuremeter test correlation in soils............................................................................ 21

2.2.3 CORRELATION BETWEEN SPT-N WITH PMT PARAMETERS........................................................26

2.3 PREVIOUS RESEARCH ON NUMERICAL SIMULATIONS OF THE PMT ..............................................2

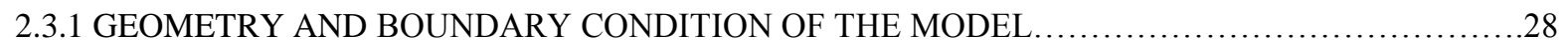

2.3.2 PROB LENGTH (L) TO DIAMETER (D) RATIO (L/D RATIO) .................................... 31

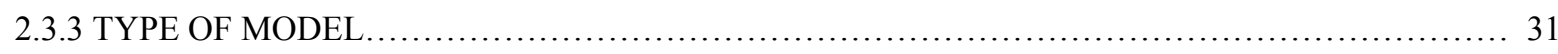




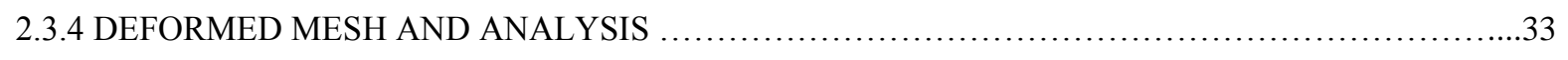

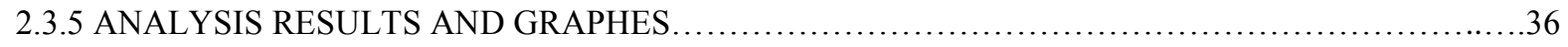

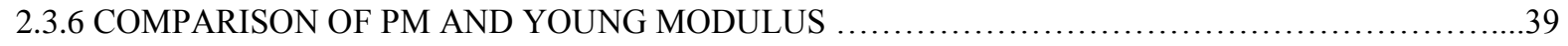

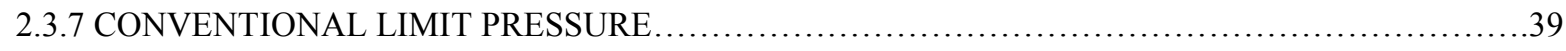

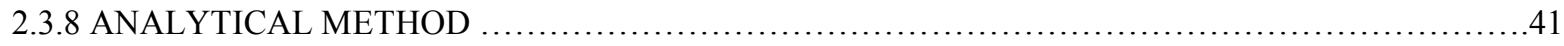

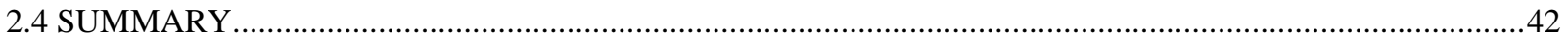

\section{CHAPTER 3: STATISTICAL CORRELATION BETWEEN SPT-N VALUE WITH PMT}

PARAMETERS FOR GLACIAL TILLS .................................................................................. 44

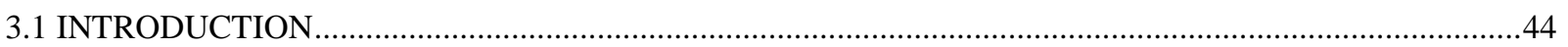

3.2 DATA SELECTION, SPT-N VALUE CORRECTION AND FILTERING ………………….....................4

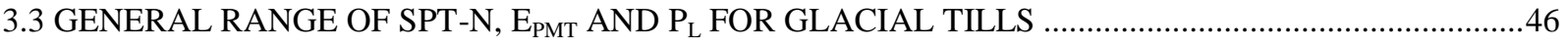

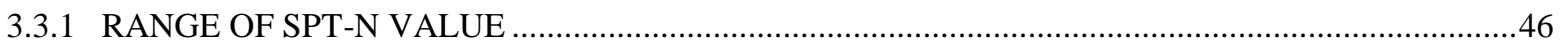

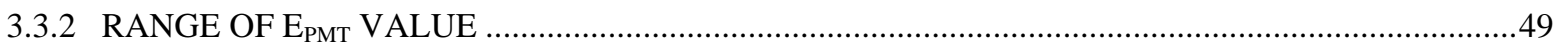

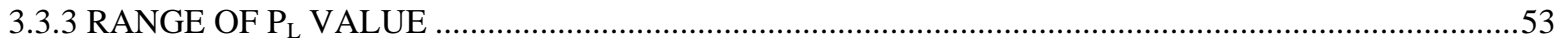

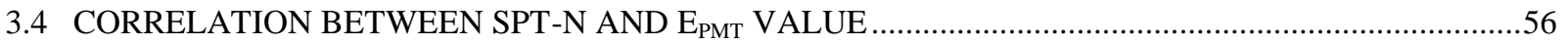

3.5 CORRELATION BETWEEN SPT-N AND P $\mathrm{L}_{\mathrm{L}}$ VALUE .....................................................................59

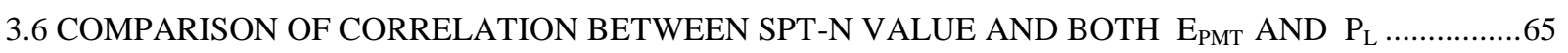

3.6.1 COMPARISON OF CORRELATION BETWEEN SPT-N VALUES AND E EMT FOR SAND ..............65

3.6.2 COMPARISON OF CORRELATION BETWEEN SPT-N VALUES AND P POR SAND ..................67

3.6.3 COMPARISON OF CORRELATION BETWEEN SPT-N VALUES WITH BOTH ...............................

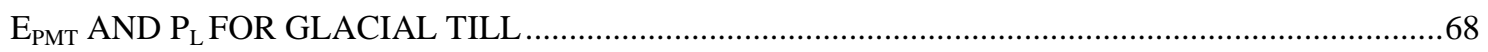

3.6.4 COMPARISON OF CORRELATION BETWEEN SPT-N VALUES AND $E_{P M T} / P_{L} \ldots \ldots \ldots \ldots \ldots \ldots \ldots \ldots . . . . . . . . . . . . . . .11$

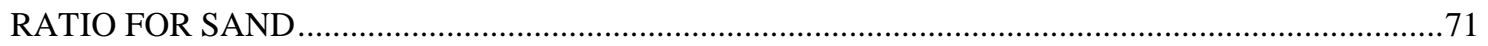

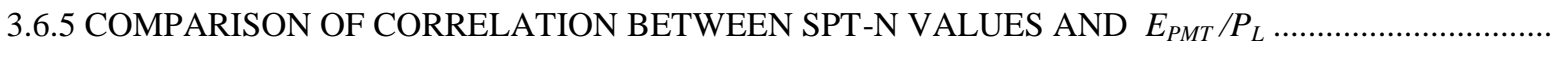

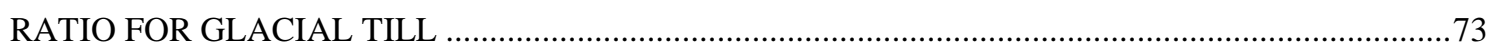

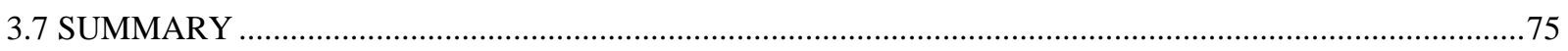

CHAPTER4: FINITE ELEMENT SIMULATION OF PMT ................................................. 77

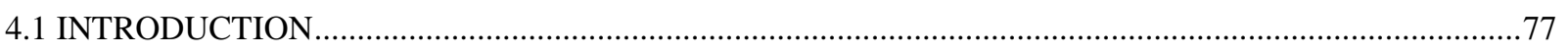

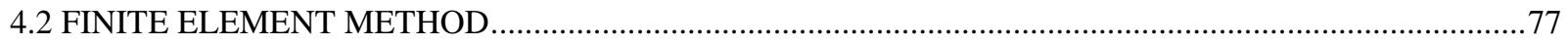

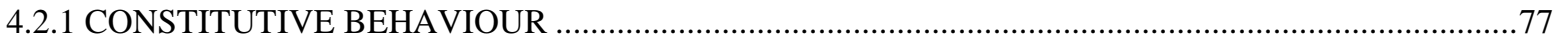

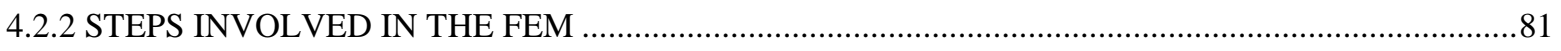

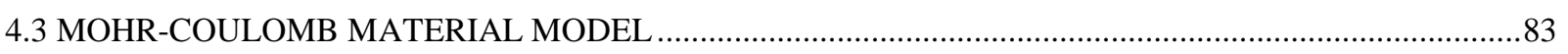

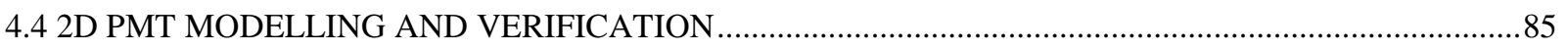

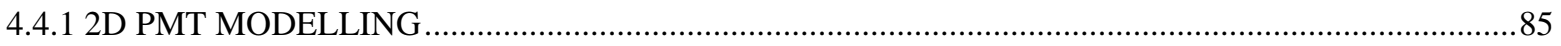

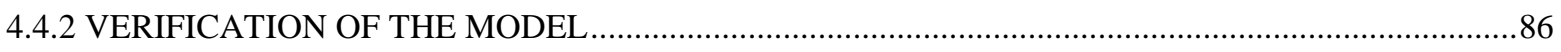

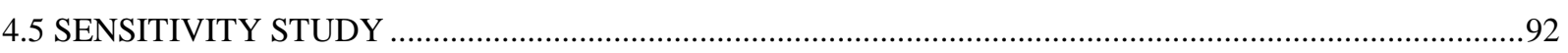




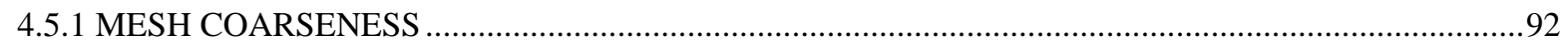

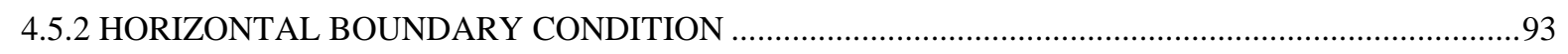

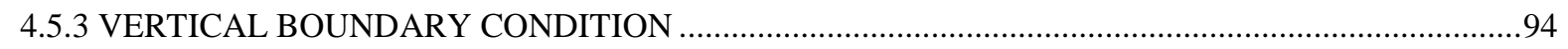

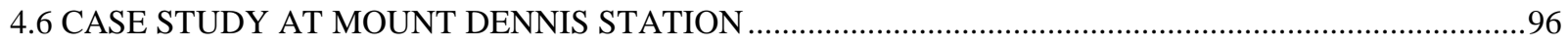

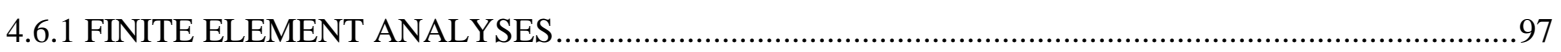

4.6.2 2D FINITE ELEMENT RESULTS AND ANALYSIS ....................................................................102

4.6.3 COMPARISON OF PRESSURE VS RADIAL STRAIN CURVES FROM PMT AND PLAXIS .........110

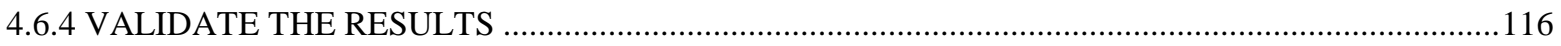

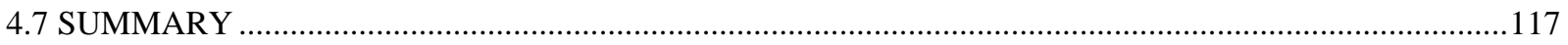

\section{CHAPTER 5: CONCLUSIONS AND RECOMMENDATIONS FOR FUTURE}

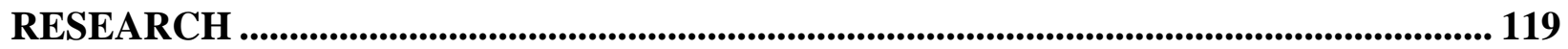

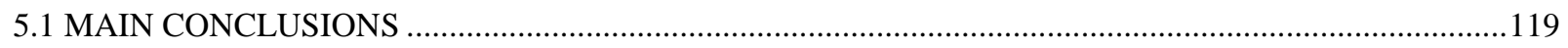

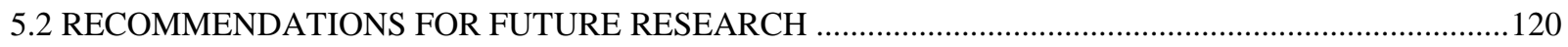

REFERENCES....................................................................................................................... 122

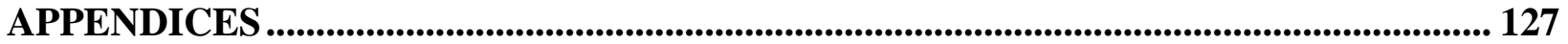




\section{LIST OF TABLES}

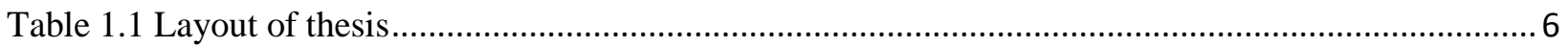

Table 2.1 Approximate correction factor for SPT-N values (after Skempton, 1986) ..............................12

Table 2.2 Compactness condition of sands from SPT ….................................................................... 13

Table 2.3 Approximate common values of the PMT parameters for clay and sand .................................2 21

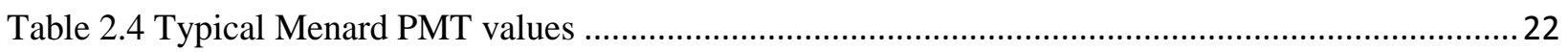

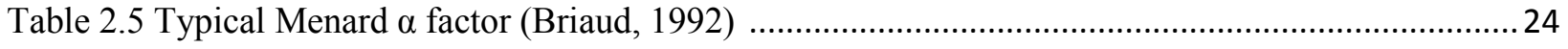

Table 2.6 Typical Young's modulus for different types of soils (Bowles, 1996) ....................................25

Table 2.7 Review of the Literature survey regards FEM simulation of PMT ........................................ 42

Table3.1 Summary of SPT-N value for different types of soils ........................................................ 47

Table3.2 Summary of $\mathrm{E}_{\mathrm{PMT}}$ value for different types of soils ............................................................. 50

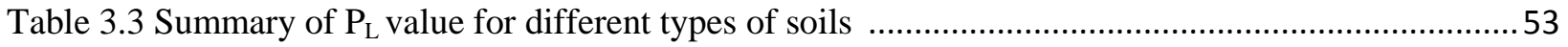

Table3.4 Summary of correlation between SPT-N value with both $\mathrm{E}_{\mathrm{PMT}}$ and $\mathrm{P}_{\mathrm{L}}$ value for different types of

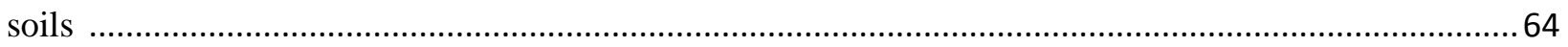

Table 3.5 Summary of range of SPT-N, $\mathrm{E}_{\mathrm{PMT}}$ and $\mathrm{P}_{\mathrm{L}}$ for corrected and filtered data ............................. 76

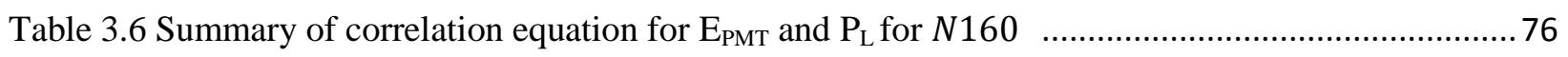

Table 3.7 Summary of $E_{P M T} / P_{L}$ ratio for filtered data …..................................................................... 76

Table 4.1 Parameters used in the M-C model for dense Hostun sand ................................................... 86

Table 4.2 Comparison of horizontal displacement related to mesh coarseness .......................................93

Table 4.3 The values of volumetric strain related to horizontal boundary condition ..............................94

Table 4.4 The value of volumetric strain related to vertical boundary condition .....................................95

Table 4.5 Summary of soil parameters used in the FEM analysis ....................................................... 98

Table 4.6 Linear correlation equations for glacial till at MD Station ................................................. 112

Table 4.7 Linear with intercept correlation equations for glacial till at MD Station .............................. 115

Table 4.8 Summary of predicted $\mathrm{E}$ and calculated and analytical $\mathrm{E}_{\mathrm{PMT}}$ at MD Station ...........................116

Table 4.9 Summary of the $E_{\text {PMT, }} E$ and Menard “ $\alpha$ ” factor for MD Station.............................................118 


\section{LIST OF FIGURES}

Figure 1.1 Typical glacial till (http://www.free-stockillustration.com ................................................ 2

Figure 1.2 Crosstown route map (http://www.thecrosstown.ca/the-project) ......................................... .3

Figure 2.1 Standard split barrel sampler used in SPT (ASTM, 2014) ..................................................... 9

Figure 2.2 The Menard pressuremeter equipment (ASTM, 2000) ........................................................ 14

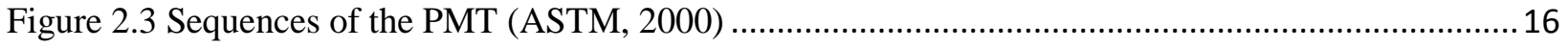

Figure 2.4 Calibration curves obtained before the PMT (Bowles, 1997) …...........................................17

Figure 2.5 Typical pressuremeter test curve (ASTM, 2000) ................................................................ 18

Figure 2.6 Determination of limit pressure from inverse of volume vs pressure curve............................20

Figure 2.7 Correlation between SPT N and net limit pressure $\left(\mathrm{P}_{\mathrm{L}}\right)$ (Briaud, 1992).................................26

Figure 2.8 Correlations between SPT N and Ep (Briaud, 1992)......................................................... 27

Figure 2.9 Correlation between SPT N and $\mathrm{E}_{\mathrm{PMT}}$ for clays (Ohya et al., 1982)...................................27

Figure 2.10 Correlation between SPT N and $E_{\text {PMT }}$ for sands (Ohya et al., 1982) .....................................28

Figure 2.11 The 2D axisymmetric model and associated mesh diagram (Malecot et al.(2012))............... 30

Figure 2.12 The 2D axisymmetric model and associated mesh diagram (Levasseur et al.(2012))...........30

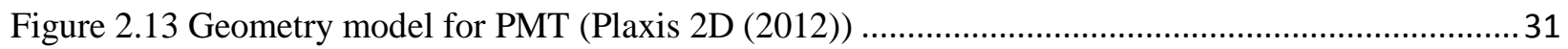

Figure 2.14 FE discretization of the calibration chamber (Schanz et al. (2000)) ..................................... 33

Figure 2.15 Points from which the displacements are read (Rita (2008)) ..............................................34

Figure 2.16 The 2D axisymmetric model and associated mesh diagram (Malecot et al.(2009))...............34

Figure 2.17 The 2D axisymmetric model and associated mesh diagram (Levasseur et al.(2009))............ 35

Figure 2.18 Deformed geometry of the PMT (Plaxis (2012))................................................................. 35

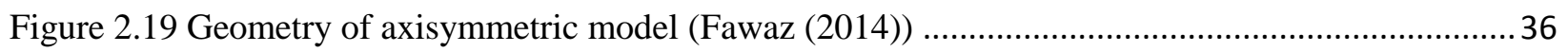

Figure 2.20 Comparison between experimental and numerical results of the PMT (Schanz et al.(20000) 37

Figure 2.21 Model and test curves at $500 \mathrm{kPa}$ of effective vertical stress (Rita (2008)) .........................37

Figure 2.22 Comparison of numerical results and PMT data (Plaxis (2012)) ............................................. 38

Figure 2.23 Experimental and numerical pressure-volume curves at different depth (Fawaz (2014)) ....... 38

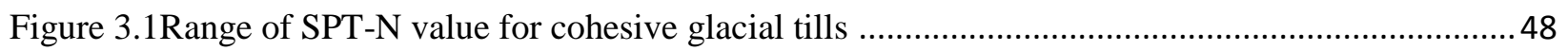

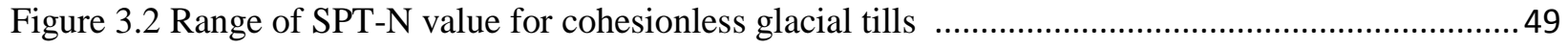

Figure 3.3 Range of $\mathrm{E}_{\mathrm{PMT}}$ value for cohesive glacial tills ................................................................. 51

Figure 3.4 Range of $\mathrm{E}_{\mathrm{PMT}}$ value for cohesionless glacial tills ............................................................ 52 
Figure3.5. Range of $\mathrm{P}_{\mathrm{L}}$ value for cohesive glacial tills

Figure 3.6 Range of $\mathrm{P}_{\mathrm{L}}$ value for cohesionless glacial tills

Figure 3.7 Correlation between SPT-N vs $\mathrm{E}_{\mathrm{PMT}}$ for cohesive glacial tills

Figure 3.8 Correlation between SPT-N vs $\mathrm{E}_{\mathrm{PMT}}$ for cohesionless glacial tills 59

Figure 3.9 Correlation between SPT-N vs $\mathrm{P}_{\mathrm{L}}$ for cohesive glacial tills 61

Figure 3.10 Correlation between SPT-N vs $\mathrm{P}_{\mathrm{L}}$ for Cohesionless glacial tills 63

Figure 3.11 Comparison of correlation between SPT- $\left(\mathrm{N}_{1}\right)_{60}$ and $\mathrm{E}_{\mathrm{PMT}}$ for sand .67

Figure 3.12 Comparison of correlation between SPT- $\left(\mathrm{N}_{1}\right)_{60}$ and $\mathrm{P}_{\mathrm{L}}$ for sand. 69

Figure 3.13(a) Comparison of correlation between SPT- $\left(\mathrm{N}_{1}\right)_{60}$ vs $\mathrm{E}_{\mathrm{PMT}}$ for linear with intercept

relationship for glacial till 70

Figure 3.13 (b) Comparison of correlation between SPT- $\left(\mathrm{N}_{1}\right)_{60}$ vs $\mathrm{P}_{\mathrm{L}}$ for linear with intercept relationship for glacial till .71

Figure 3.14 (a) Correlation between $\mathrm{E}_{\mathrm{PMT}}$ vs $\mathrm{P}_{\mathrm{L}}$ for sand . .72

Figure 3.14 (b) Correlation between $E_{P M T} / P_{L}$ vs SPT- $\left(\mathrm{N}_{1}\right)_{60}$ for sand .73

Figure 3.15 (a) Correlation between $\mathrm{E}_{\mathrm{PMT}}$ vs $\mathrm{P}_{\mathrm{L}}$ for glacial till ............................................................. 74

Figure 3.15 (b) Correlation between SPT- $\left(\mathrm{N}_{1}\right)_{60}$ vs $E_{P M T} / P_{L}$ for glacial till ............................................ 75

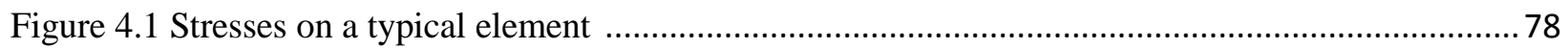

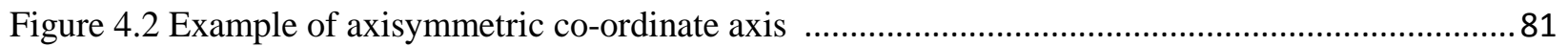

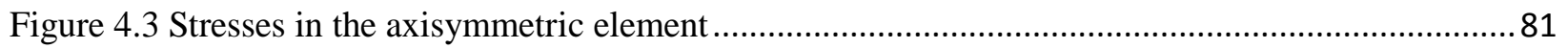

Figure 4.4 Mohr's circles of effective stress (Ports and Zdravkovic (2001)) .......................................... 84

Figure 4.5 Mohr - Coulomb yield surfaces in principal stress space (Ports and Zdravkovic (2001))......... 85

Figure 4.6 2D axisymmetric model and associated mesh (Levasseur et al. (2009)) ................................87

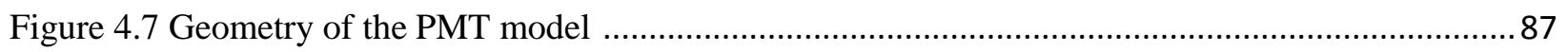

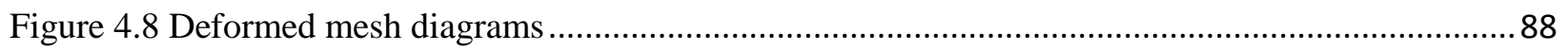

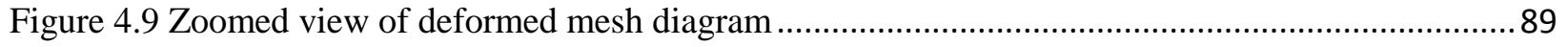

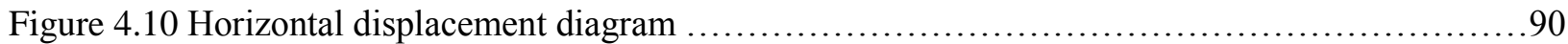

Figure 4.11 Zoomed view of horizontal displacement diagram................................91

Figure 4.12 Pressure (p) vs volumetric strain $(\Delta v / V)$ curves for verification of the model .....................92

Figure 4.13 Pressure (p) vs volumetric strain $(\Delta v / V)$ curves for horizontal boundary conditions ............94

Figure 4.14 Pressure $(\mathrm{p})$ vs volumetric strain $(\Delta v V)$ curves for vertical boundary conditions ..................94

Figure 4.15 Soil profile at MD Station according to borehole MD101-PMT and test @6.0m ...............100

Figure 4.16 Typical FE mesh for numerical simulation at MD Station ............................................... 101 
Figure 4.17 Water table diagram for soil profile at MD Station @ test depth 6m after generate the in-situ

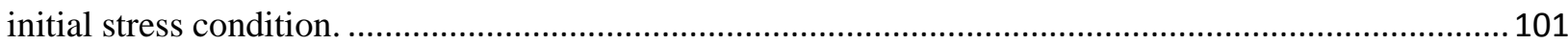

Figure 4.18 Typical deformed meshes @ 6.0 m depth at MD Station....................................................103

Figure 4.19 Zoomed views of the deformed meshes diagram@ $6.0 \mathrm{~m}$ depth at MD Station ...................104

Figure 4.20 Typical horizontal displacements arrow diagram @ 6.0m depth at MD Station...................105

Figure 4.21 Zoomed views of the horizontal displacements arrow diagram @ 6.0m depth at MD Station 106

Figure 4.22 Typical horizontal displacement shaded diagram @ 6 m depth at MD Station.............107

Figure 4.23 Zoomed view of horizontal displacement shaded diagram @ $6 \mathrm{~m}$ depth at MD Station.....108

Figure 4.24 Typical horizontal displacement cross section @ 6.0m depth at MD Station ........................108

Figure 4.25 Zoomed view of horizontal displacement cross section (along the probe) @6.0m depth at MD

Station 109

Figure 4.26 Pressure vs radial strain graph at $6 \mathrm{~m}$ depth for MD Station ...............................................111

Figure 4.27 Linear relationship for $\mathrm{E}_{\mathrm{PMT}} \mathrm{vs} \mathrm{E}$ for cohesionless glacial till at MD Station ...................... 114

Figure 4.28 Linear relationship for $\mathrm{E}_{\mathrm{PMT}} \mathrm{vs} \mathrm{E}$ for cohesive glacial till at MD Station ........................... 115 


\section{CHAPTER 1: INTRODUCTION}

\subsection{RESEARCH BACKGROUND}

Statistical correlations between in-situ soil testing results and soil parameters are increasingly used during various stages of geotechnical engineering work. Statistical correlation equations are used during the early stage of engineering design work since they are more practical ways to proceed than extensive in-situ testing programs. In geotechnical design work statistical correlations are widely used to predict unknown parameters from simple known parameters, and save the time and cost.

Many geotechnical design parameters of the soil can be derived from Standard Penetration Test (SPT) and SPT is widely used around the world. On the other hands, Pressuremeter Test (PMT) is becoming increasing more popular for site investigation and geotechnical design especially in estimating soil properties for foundation design.

The numerical simulation of the PMT in use of the Finite Element Method (FEM) becomes more and more popular in geotechnical engineering. This method assumes to model the soil behavior by constitutive equation. A lot of soil constitutive models deal with a large variety of geotechnical problems. Nevertheless, these constitutive models have most of the time a large number of parameters whose values are unknown.

\subsection{ENGINEERING BACKGROUND}

This study is performed in the Eglinton Crosstown Light Rail Transit (ECLRT) project in Toronto. The site is situated along Eglinton Avenue from the existing Kennedy Subway Station in the east to the Mount Dennis Station in the west, in Toronto, Ontario, Canada.

The Toronto area acquired at least three glacial and two interglacial periods from the published geological data (Karrow (1967) and Sharpe (1980)). The geological history of the Toronto area 
has included several advances and retreats of glaciers of Illinoian and Wisconsinan age (Karrow and White (1998)). The glacial tills in this area were generally deposited during the early to late Wisconsinan periods, represented by the Sunnybrook, Seminary, Meadowcliffe, Newmarket and Halton tills (Sharpe et al. (1999)). The glacial till deposits in Toronto can be divided into low plasticity cohesive glacial tills (silty clay to clayey silt glacial till) and cohesionless glacial tills (sandy silt to silty sand glacial till) (Manzari et al. (2014)). This kind of soil is derived due to the wearing away and entrainment of material as a result of the moving ice of a glacier. As shown in Figure 1.1, this type of soil can be described as high variability materials in both horizontal and vertical axis, and it normally contains complex non-linear stress-strain characteristics (Baker et al. (1998)).

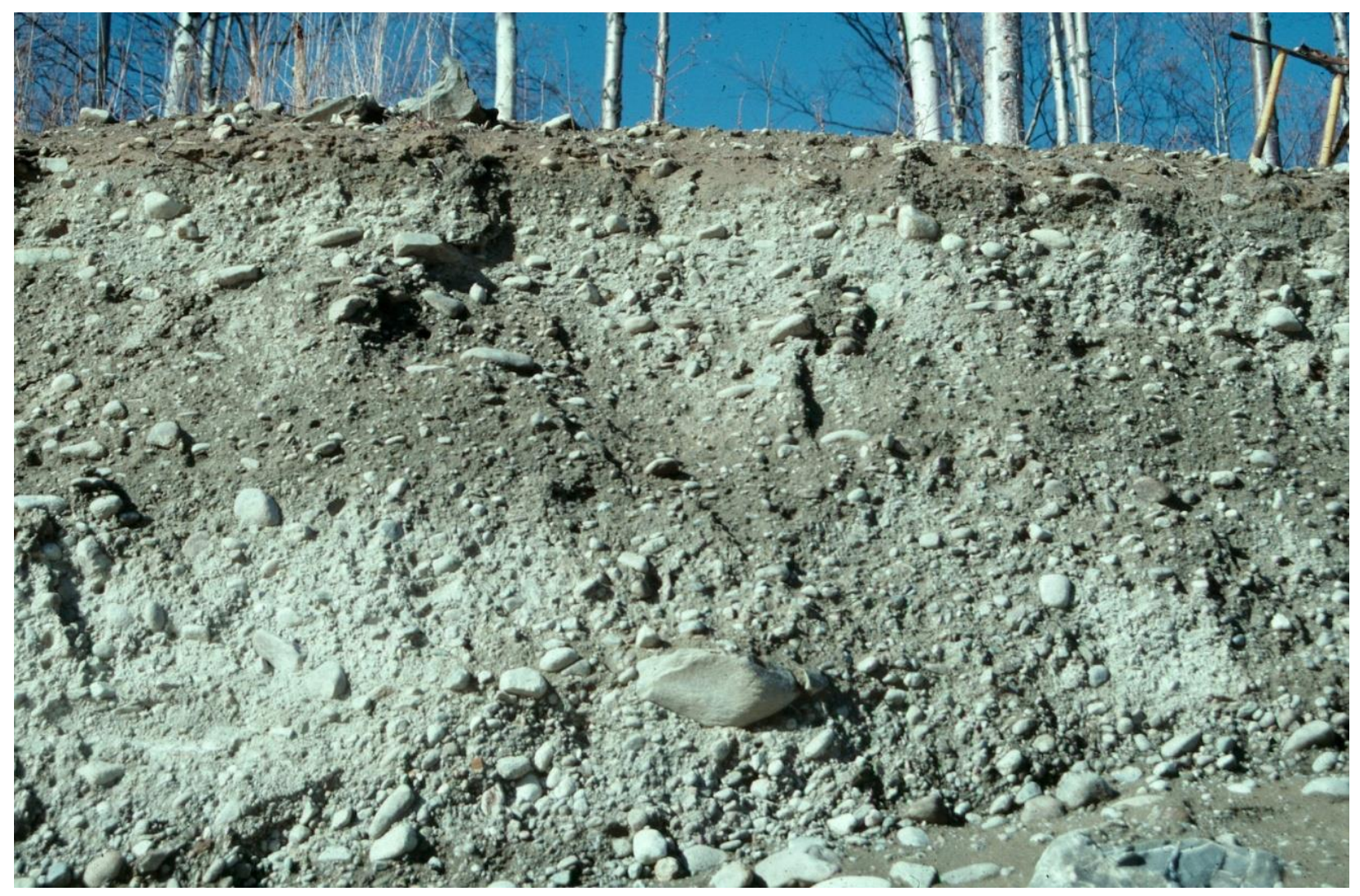

Figure 1.1 Typical glacial till (Source- Mark Clark, http://www.free-stockillustration.com)

In addition to that, the tills consist of a heterogeneous mixture of gravel, sand, silt and clay size particles in varying proportions. Cobbles and boulders are common in these deposits (Robert et al. (2011)). The recorded maximum boulder size founded in Toronto so far has been about $3 \mathrm{~m}$ in 
the maximum dimension. Boulder volume ratios (BVR) (total boulder volume per volume of excavated earth material) of $0.12 \%$ and $0.17 \%$ for interglacial deposits and glacial tills respectively have been recommended for TTC Subway projects such as the Sheppard Subway (Boone and Shirlaw (1996)) and the Toronto - York Spadina Subway extension (Boone and Westland (2008)).

The proposed ECLRT is approximately $33 \mathrm{~km}$ in length and located approximately $7 \mathrm{~km}$ north of Lake Ontario. There are 25 proposed stations along the alignment as shown in Figure 1.2.

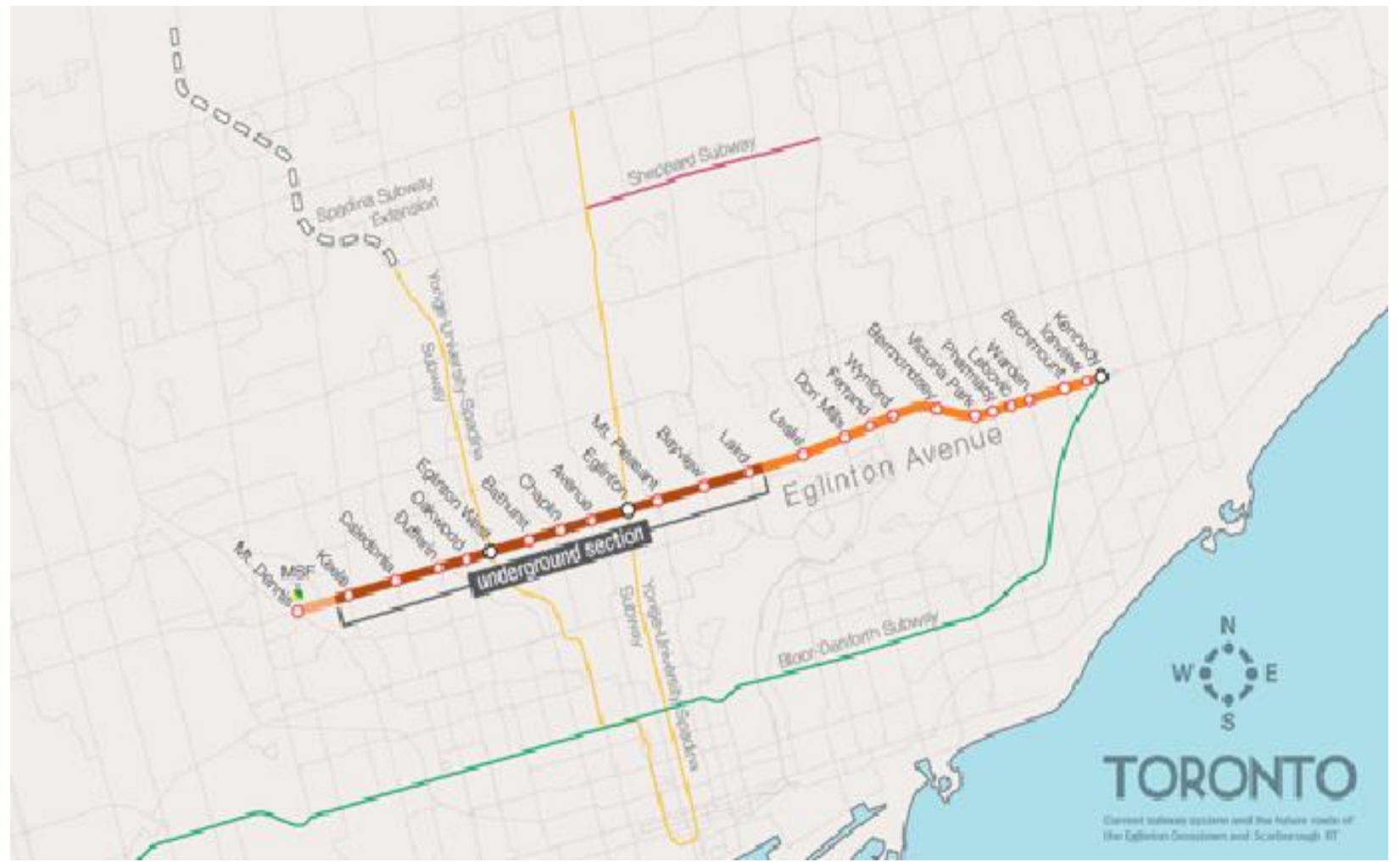

Figure 1.2 Crosstown route maps (http://www.thecrosstown.ca/the-project)

A series of laboratory and in-situ tests were conducted in advance at the above stations. The insitu tests included SPTs, field vane shear tests, pre-bored TEXAM PMTs and seismic tests. The laboratory tests included density and moisture content measurements, grain size and hydrometer analysis, consistency (Atterberg) limit tests, consolidation tests, consolidated undrained and drained triaxial compression tests. 
Based on these tests, the soil is classified as a glacial till which further classified as low plasticity cohesive glacial till and cohesionless glacial till according to the current version of TTC geotechnical standards (2014). In this area, the low plasticity cohesive glacial till mostly consists

of the following soil types such as (i) silty clay till (ii) clayey silt till. The cohesionless glacial till mostly consists of following soil types such as (iii) sandy silt till (iv) silty sand till. The glacial tills are interbedded with silty clay, clayey silt, sandy silt, sand and silt and silty sand. However, the behavior of glacial tills in southern Ontario is not fully understood.

\subsection{NEED FOR RESEARCH}

The SPT is a well-established method of investigating soil properties. The differences in testing practices can be at least partly compensated by changing the measured $\mathrm{N}$ to $\left(\mathbf{N}_{\mathbf{1}}\right)_{\mathbf{6 0}}$. There are many possible applications to correct the field measured SPT-N. There is no any general agreements on these applications of corrections of field measured SPT-N. In contrast to heavy criticisms about the SPT-N correction, there is strong needed to recommend a suitable correction method for more suitable for local conditions.

Estimation of the PMT parameters such as PM modulus $\left(\mathrm{E}_{\mathrm{PMT}}\right)$ and pressure limit $\left(\mathrm{P}_{\mathrm{L}}\right)$ from SPT $-\mathrm{N}$ value has been studied by a few researchers in the past. Attempted correlations have usually been weak because of the differences in the methods and uncertainties involved in the tests. Even though, they are widely used in practice to get an idea about the level of the geotechnical parameters used in the design. The most of the correlation work done in the past was for sand and clay. There is almost no correlative work on glacial till especially Toronto glacial till. Hence research is needed to avoid these short comes and recommended a suitable relationship more suitable for local condition especially glacial tills in the city of Toronto.

In the case of numerical simulation of PMT, there is bulk of information available but none of these simulations is performed for real soil profile. The length to diameter ratio of the probe is influenced in the plain strain condition of the probe. A very little information is available on back calculating the PM modulus from pressure-volume curve which is obtained from simulation. However, this modulus differs from the elastic Young's modulus (E) which is the 
principal soil parameter. The deduction of the Young's modulus from PM modulus is still under

research. Menard developed ratio of $\frac{E_{P M T}}{E}$ for peat, clay, silt, sand, sand and gravel. Currently there is no such a relationship available for glacial tills in the city of Toronto. Hence there is a strong need for an in-depth research to develop and recommend suitable relationship for glacial tills in the city of Toronto.

\subsection{OBJECTIVES OF THE STUDY}

The main objectives of this thesis are listed below.

(i) To correct the field measured SPT-N and develop a ratio of corrected SPT-N $\left(\left(\mathrm{N}_{1}\right)_{60}\right)$ to field measured SPT-N $\left(\mathrm{N}_{\mathrm{F}}\right)$ which is ratio of $\left(\frac{\left(N_{1}\right)_{60}}{N_{F}}\right)$ for glacial tills.

(ii) To establish the ranges of SPT-N, $\mathrm{E}_{\mathrm{PMT}}$ and $\mathrm{P}_{\mathrm{L}}$ for glacial tills.

(iii) To develop the statistical correlation relationships between SPT $-\mathrm{N}$ values with PMT parameters such as PM modulus ( $\left.\mathrm{E}_{\mathrm{PMT}}\right)$ and pressure limit $\left(\mathrm{P}_{\mathrm{L}}\right)$ for glacial tills.

(iv) To develop the statistical correlation equations between PM modulus ( $\mathrm{E}_{\mathrm{PMT}}$ ) with Young's modulus (E) for glacial tills by using Finite Element Method (FEM).

(v) To develop the Menard's ' $\alpha$ ' factors which is the ratio of $\frac{E_{P M T}}{E}$ for glacial tills.

\subsection{RESEARCH METHODOLOGY}

Statistical analysis is carried out to investigate the relationship between SPT-N values with PMT parameters such as $\mathrm{PM}$ modulus $\left(\mathrm{E}_{\mathrm{PMT}}\right)$ and pressure limit $\left(\mathrm{P}_{\mathrm{L}}\right)$ for glacial tills in the city of Toronto based on soil investigation for the ECLRT project, Canada. The first step is to collect the pairs of PMT data and SPT-N value at the same depth in the same test area. After collect these data, the field measured SPT-N values are corrected and filtered. Then an attempt is made to develop a correlation between corrected and filtered SPT-N values with PMT parameters. As emphasized by Phoon and Kulhawy (1999), local correlations that are developed within a specific geologic setting generally are preferable to generalized global correlations because they are significantly more accurate. 
Numerical analysis of PMT is performed using Plaxis 2D software. The Mohr-Coulomb (M-C) material model is used in this simulation. The appropriate parameters required are grasped from ECLRT geoengineering factual data reports for different types of soils. Those identified and extracted values are used in M-C material model which is in the constitutive model. The pressure-radial strain curve obtained from this simulation is used to compute the PM modulus ( $\left.\mathrm{E}_{\mathrm{PMT}}\right)$. This is determined from the quasi-linear part of the pressure vs radial strain curve. However, this modulus differs from the elastic Young's modulus (E) which is the principal soil parameter. The PM modulus has been related to the elastic Young's modulus for the glacial tills. Then Menard's rheological factors " $\alpha$ " which is the ratio of $\frac{E_{P M T}}{E}$ are derived for glacial tills.

These findings will help geotechnical community in evaluating and interpreting geotechnical parameters for their clients.

\subsection{THESIS OUTLINE}

This thesis consists of five chapters including references and annex. The thesis outline is shown in Table1.1.

Table1.1 Layout of thesis

\begin{tabular}{|l|l|l|}
\hline \multicolumn{1}{|c|}{ Chapter } & \multicolumn{1}{|c|}{ Title } & \multicolumn{1}{|c|}{ Content } \\
\hline Chapter 1 & Research background & $\begin{array}{l}\text { Introduction, engineering background, need for } \\
\text { research, objectives and methodology. }\end{array}$ \\
\hline Chapter 2 & Literature review & $\begin{array}{l}\text { Literature review on SPT, PMT, correlation between } \\
\text { SPT and PMT, and simulation of PMT. }\end{array}$ \\
\hline Chapter 3 & $\begin{array}{l}\text { Statistical correlation } \\
\text { between SPT-N and } \\
\text { PMT for glacial tills }\end{array}$ & $\begin{array}{l}\text { Correction for field measured SPT-N and SPT-N } \\
\text { correction ratio. } \\
\text { Develop the ranges of SPT-N, EPMT and } \text { PL }_{\text {for glacial }} \\
\text { tills. } \\
\text { Develop correlation equations between SPT-N values } \\
\text { with PMT parameters such as E EMT and } \text { P }_{\mathrm{L}} \text { for glacial } \\
\text { tills. }\end{array}$ \\
\hline
\end{tabular}




\begin{tabular}{|l|l|l|}
\hline & & $\begin{array}{l}\text { Compare these values and correlation equations with } \\
\text { literature. }\end{array}$ \\
\hline Chapter 4 & $\begin{array}{l}\text { Finite Element } \\
\text { Method simulation of } \\
\text { PMTs in glacial tills }\end{array}$ & $\begin{array}{l}\text { FEM simulation is performed for PMTs by using } \\
\text { Plaxis 2D. The M-C material model is adopted in this } \\
\text { simulation. } \\
\text { Develop correlation between PM modulus (EMT) and } \\
\text { Young's modulus (E) for glacial tills. } \\
\text { Develop Menard " } \alpha \text { " factors for glacial tills. }\end{array}$ \\
\hline Chapter 5 & $\begin{array}{l}\text { Conclusions and } \\
\text { Recommendations }\end{array}$ & $\begin{array}{l}\text { Content of conclusions and recommendations for } \\
\text { future research. }\end{array}$ \\
\hline Appendices & & $\begin{array}{l}\text { Content of borehole reports, PMTs results, SPT-N } \\
\text { corrections calculation sheets. }\end{array}$ \\
\hline
\end{tabular}




\section{CHAPTER 2: LITERATURE REVIEW}

\subsection{INTRODUCTION}

This chapter presents the results of the literature review conducted during the study. Information available from specific research studies on statistical correlation between SPT with PMT are very few, as only a few researchers have studied for sand and clay, even rare for Toronto glacial till. Such information, as it was considered very valuable, is presented in the first part of this chapter. Further literature survey was conducted on numerical simulations of the PMT. As a bulk of information on modelling has been emanated through actual practice and through available theory in the past researchers, the information gathered from those sources are presented in the second part of this chapter. This literature survey provided the background information for the formulation and execution of the research study.

\subsection{PREVIOUS RESEARCH ON STATISTICAL CORRELATION BETWEEN SPT AND PMT}

\subsubsection{STANDARD PENETRATION TEST (SPT)}

Standard penetration test (SPT) was first introduced in early 1900's by driving an open end pipe into soil during wash boring process and it has become the most extensively used in-situ test in site investigation practice.

Originally, the test was used to determine the relative density of granular soils. The idea of the SPT at the beginning was the comparison of blows required to penetrate the tested soil. If the number of blows for a tested location was larger than another tested location, it was concluded that the denser soil is the one with the largest blow count. Although SPT had been performed only for granular soils in the past, it is executed in almost all kinds of soil today including weak rock. 


\subsubsection{Equipment and Test Procedure}

The SPT is a well-established method for soil investigation. As many forms of the test are in use worldwide, standardization is essential to facilitate the comparison of results from different investigations, even at the same site (Thorburm (1986)). In 1958, the test method was standardized by ASTM D1586. This means that the test standardized using a $50 \mathrm{~mm}$ outside diameter split spoon sampler with dimensions shown in Figure 2.1, is driven into soil with a 64 $\mathrm{kg}$ weight having a free fall of $760 \mathrm{~mm}$ auto hammer. The blows required to drive the splitbarrel sampler a distance of $305 \mathrm{~mm}$, after an initial penetration of $152 \mathrm{~mm}$, is referred as the SPT-N value. Procedure is repeated after the drilling to the depth of the next test. (Conventionally test is performed at every 1.0 to $1.5 \mathrm{~m}$ intervals). In this study, SPT is performed in accordance with the ASTM D 1586 method.
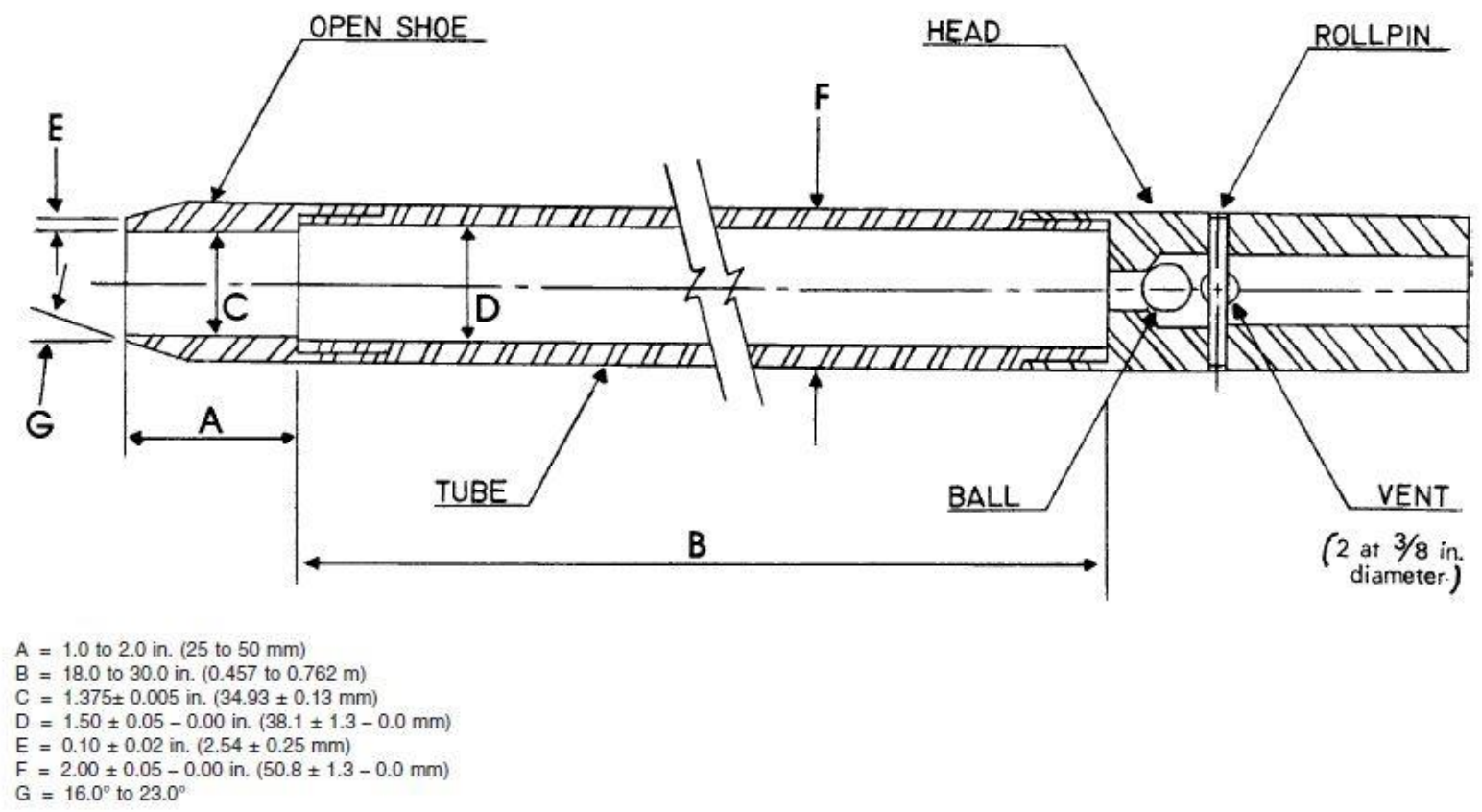

Figure 2.1 Standard split barrel sampler used in SPT (ASTM (2014)) 


\subsubsection{SPT-N correction}

The main reasons for extensive use of SPT in the site exploration can be related to many factors such as availability of equipment, simplicity of the operation, applicability in the type of soils and process of sampling. Due to all of these practical aspects, the results of SPT-N value can be dramatically affected by drilling operation, the type of equipment, capability of the operator, presence of size of particles (such as gravels, cobbles and boulders) and ground water conditions.

The SPT is usually stopped on the following situation where 50 or more blows are required for $150 \mathrm{~mm}$ penetration, 100 blows are obtained to drive the required $300 \mathrm{~mm}$ and 10 successive blows produce no advance. If any of the above situations is encountered during the test, SPT-N value for the relevant depth is recorded as "refusal" and indicated with the letter "R" in the borehole logs.

In the above refusal situation the recorded field SPT-N value has to be corrected using Equation 2.1 according to Cao et al. (2015) with measured penetration depth.

$N_{F}=\frac{305 N}{\Delta s}$

Where $\quad N_{F}-$ Corrected SPT-N value

$N$ - Field recorded SPT-N value

$\Delta s$ - Measured penetration depth in $\mathrm{mm}$

Because of the variability in equipment and operating conditions, the direct use of SPT results for geotechnical design is not recommended. As a result, many corrections shall be done on the field SPT-N values. These corrections can be summarized in an equation formatted as given below according to the Canadian Foundation Engineering Manual (2006).

$\left(N_{1}\right)_{60}=\mathrm{C}_{\mathrm{E}} \mathrm{C}_{\mathrm{N}} \mathrm{C}_{\mathrm{R}} \mathrm{C}_{\mathrm{B}} \mathrm{C}_{\mathrm{S}} N_{F}$

$\left(N_{1}\right)_{60}=\mathrm{C}_{\mathrm{N}} N_{60}$ 


$$
N_{60}=\mathrm{C}_{\mathrm{E}} N_{F}
$$

$\mathrm{C}_{\mathrm{N}}=\left(\frac{P}{\sigma^{1}}\right)^{0.5}$

$\mathrm{C}_{\mathrm{E}}=\frac{E R_{R}}{60}$

Where $C_{E}-$ Hammer energy correction factor

$E R_{R}-$ Rod energy ratio

$\mathrm{C}_{\mathrm{N}}$ - Overburden pressure correction factor

$\mathrm{P}$ - Atmospheric pressure

$\sigma^{\prime}$ - Effective overburden pressure

$\mathrm{C}_{\mathrm{R}}$ - Rod length correction factor

$\mathrm{C}_{\mathrm{B}}$ - Borehole diameter correction factor

$\mathrm{C}_{\mathrm{S}}$ - Sampler correction factor

$N_{F}$ - Corrected SPT-N value for penetration depth

$N_{60}$ - SPT-N value corrected to $60 \%$ of theoretical free fall hammer energy

$\left(N_{1}\right)_{60}$ - SPT-N value correctd for both vertical effective stress and input energy

In the literature, most researchers express their concerns regards energy correction which was elaborated as follows. The energy delivered to the rods during a SPT expressed as a ratio of the theoretical free fall potential energy, can vary from 30\% to 90\% (Kovacs and Salomone (1982) and Robertson et al. (1983)). Schmertmann and Palacios (1979) have shown that the SPT blow count is inversely proportional to the delivered energy. Kovacs et al. (1984), Seed et al. (1984) and Robertson et al. (1983) have recommended that the SPT-N value has to be corrected to an energy level of 60\% (CFEM (2006)). The SPT N-values corresponding to $60 \%$ efficiency are termed $N_{60}$. The practice in the United States/Canada the SPT N-value measured to an average energy ratio of $60 \%\left(\mathrm{ER}_{\mathrm{R}}=60 \%\right)$ according to ASTM D1586-11 (2014). In this study energy ratio of $60 \%\left(\mathrm{ER}_{\mathrm{R}}=60 \%\right)$ is adopted.

Other correction factors such as $C_{R}, C_{S}$ and $C_{B}$ are mentioned in Table 2.1 according to CFEM (2006) (after Skempton (1986)) is adopted in this study. 
Table2.1 Approximate correction factors for SPT-N values (after Skempton (1986))

\begin{tabular}{|c|c|c|}
\hline Correction factor & Item & Correction factor value \\
\hline $\mathrm{C}_{\mathrm{R}}$ & Rod length (below anvil) & \\
& $>10 \mathrm{~m}$ & 1.0 \\
& $6-10 \mathrm{~m}$ & 0.95 \\
& $4-6 \mathrm{~m}$ & 0.85 \\
& $3-4 \mathrm{~m}$ & 0.70 \\
\hline $\mathrm{C}_{\mathrm{S}}$ & Standard sampler & 1.0 \\
& US sampler without liner & 1.2 \\
\hline $\mathrm{C}_{\mathrm{B}}$ & Borehole diameter & \\
& $65-115 \mathrm{~mm}$ & 1.0 \\
& $150 \mathrm{~mm}$ & 1.05 \\
& $200 \mathrm{~mm}$ & 1.15 \\
\hline
\end{tabular}

Bowles (1997) suggested that there are three possible approaches about correction of SPT-N value.

(i) Do nothing on the field recorded $\mathrm{N}$ value

(ii) Adjust only for overburden pressure

(iii) Apply all of the mention corrections

Since there is no any general agreement on the application of corrections to the field record SPT$\mathrm{N}$ value, many of the correlation with SPT-N value only suggests energy correction, in some cases overburden correction was recommended. However, overburden correction for fine grained soils is still considered as controversial issue and not preferred in practice (Sivrikaya and Togrol, (2007)).

In contrast to serious criticisms about SPT for being destructive and sensitive to many factors, it is still most commonly used in-situ test in the geotechnical engineering practices. 


\subsubsection{Interpretation of SPT}

A term describing the compactness condition of a cohesionless soil is often interpreted from the results of a SPT. Compactness and penetration values are often related to Table 2.2, which was proposed by Terzaghi and Peck (1967). Notice that the term "compactness condition" replaces the earlier term "relative density" used in the past according to CFEM (2006).

Table 2.2 Compactness condition of sands from SPT

\begin{tabular}{|c|c|}
\hline Compactness condition & SPT-N Index (blows per 0.3 m) \\
\hline Very loose & $0-4$ \\
\hline Loose & $4-10$ \\
\hline Compact & $10-30$ \\
\hline Dense & $30-50$ \\
\hline Very dense & Over 50 \\
\hline
\end{tabular}

\subsubsection{PRESSUREMETER TEST (PMT)}

The PMT was invented by German Kogler (1930) in order to measure a soil deformation modulus. Due to the technology of that time, the unit was not operational. Furthermore, the inventor has failed to correctly interpret the results and the unit was abandoned.

In 1954 a young French engineer, Louis Menard, took up the idea in the refining the inflatable cylinder Kogler, he added two guard cells to the central measuring cell, avoiding the expansion of the drilling and thus making interpretable test. The unit became operational quickly because of advances in technology.

Now a day the PMT is becoming more popular in Ontario for site investigation and geotechnical design especially in estimating soil properties for foundation design. Louis Menard developed the pre-bored PMT device and considered it to be one of the most precise testing methods available for almost any type of soil (Menard (1965)). 


\subsubsection{Equipment and Test Procedure}

\section{Equipment}

The pressuremeter consists of three main parts which are a probe, a control unit and tubing for inflation as shown in Figure 2.2.

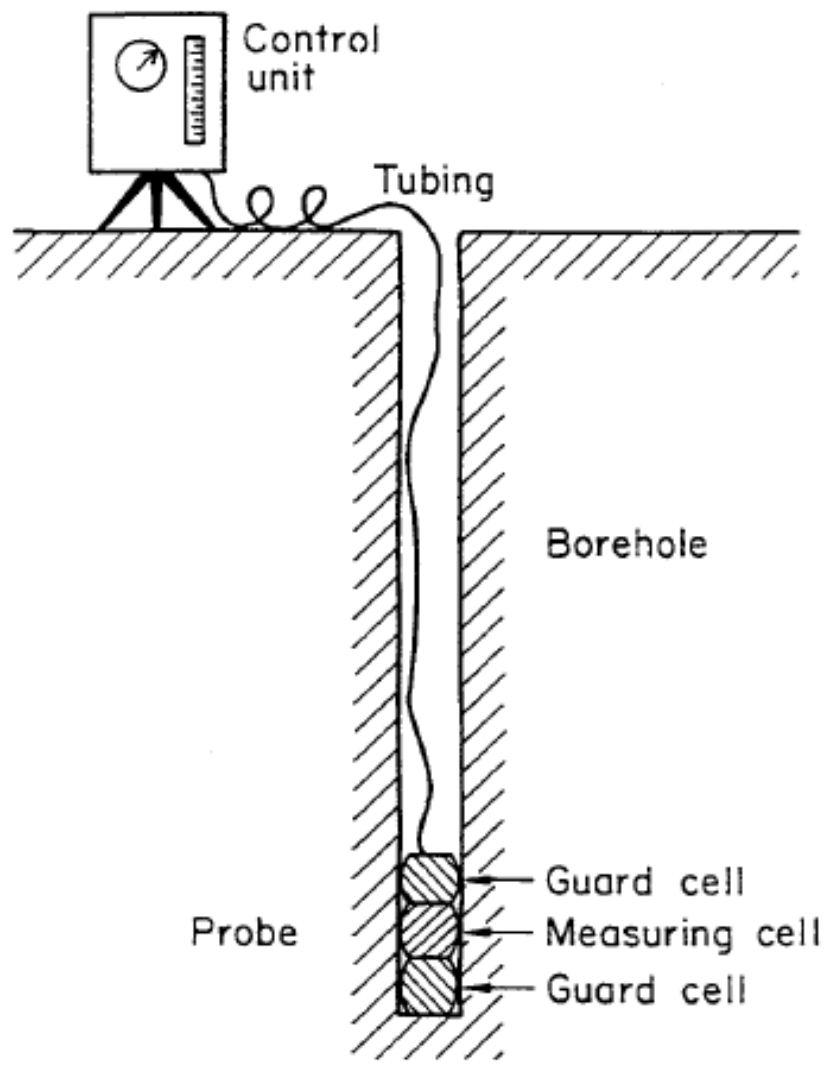

Figure 2.2The Menard pressuremeter equipment (ASTM (2000))

(i) Probe: A typical Menard type PM probe includes three separate cells namely as top cell, loading cell and bottom cell. Top and bottom cells are usually called "guard" cells which are filled with gas before the test in order to isolate the loading cell from end condition effects. Load cell is a flexible membrane (usually made from rubber) that is filled with water after the guard cells are inflated. The two guard cells are used to reduce end effects on the middle cell which will produce predominantly radial strains in the soil. Lateral displacements are measured only in the middle cell. 
(ii) Control unit: A metal case that houses the main cylinder, four quick connectors and the control valve. It consist a manual actuator to operate the piston and digital pressure gauge. It is used for both controlling the pressure given to the probe and monitoring the volume changes with respect to pressure increase by the dial gauges.

(iii) Tubing: A high pressure single conduit fitted with a shut off quick connector to keep the probe and tubing saturated.

Currently, many types of PMs have been developed besides original Menard type PM such as self -boring and push in PMs which can be used for different in-situ soil conditions.

\section{Borehole preparation}

It is extremely important to minimize disturbance of the borehole wall during, the drilling process. Drilling methods should be selected to prevent collapse of the borehole wall, minimize erosion of the soil and prevent softening of the soil (Finn et al. (1984)). Good test results begin with a high quality borehole having minimal disturbance to its side walls, typically requiring mud wash rotary techniques which was recommended (Briaud (2013)). Maintain the drilling mud level at or near the top of the borehole minimizes the horizontal stress release from drilling. During drilling, the operator should carefully monitor the rotation rate, advance rate and mud flow to obtain a high quality borehole.

\section{Test procedure}

PMT is performed either by application of pressure in equal increments (stress controlled) or equal volume increments (strain controlled). In stress control test, apply the pressure on the control unit in about equal increments, until the expansion of the probe during one load increment exceeds about $1 / 4$ of $V_{0}$. Generally 25, 50, 100 or $200 \mathrm{kPa}$ pressures are selected for testing soils. Too small steps will result in an excessively long test, too large steps may yield result with inadequate accuracy. The pressure steps should be determined in such a way that about 7 to 10 load increments are obtained. In a strain control test, increase the volume of the probe on volume increments of 0.05 to 0.1 times the volume $V_{0}$ until the limit of the equipment is 
reached. For both procedures, take readings after 30s and $1 \mathrm{~min}$ after the pressure or volume increment have been applied. Volume readings are recorded to an accuracy of $0.2 \%$ of $V_{0}$ and pressure readings to an accuracy of $5 \%$ of the limit pressure. The sequences of the PMT are shown in Figure 2.3.

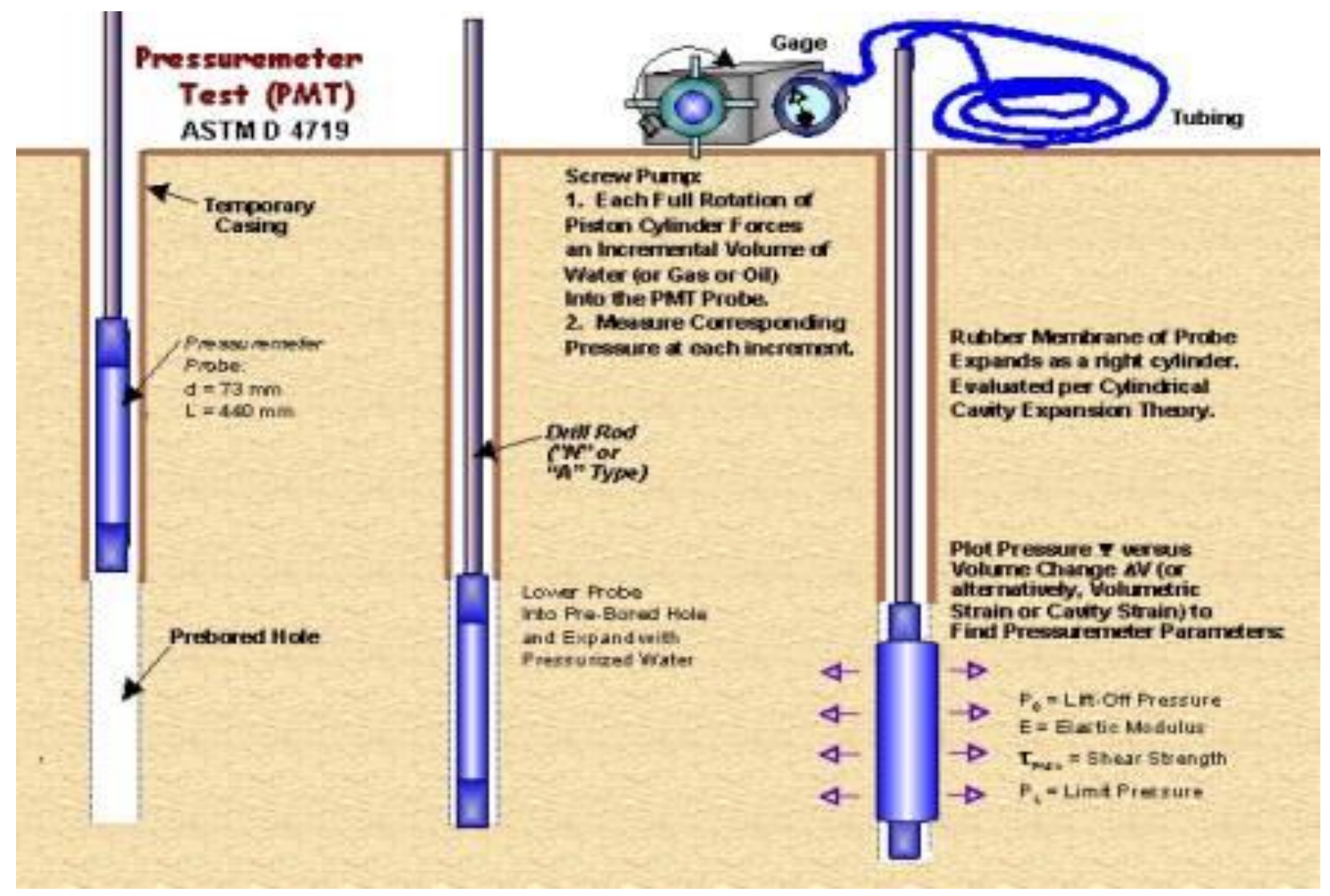

Figure 2.3 Sequences of the PMT (ASTM (2000))

\subsubsection{Calibration}

Before the test, two main calibration namely as volume and pressure calibration are required in order to correct the raw data obtained during the test. Those calibrations are explained below.

Volume calibration: Volume calibration is performed for detection of the leaks in the system and making necessary adjustments about system compressibility. PM probe is usually placed in a steel tube before the volume calibration and the pressure is increased in steps. For a given 
pressure, the volume lost is determined since the probe is confined by the tubes. A typical volume calibration curve is given in Figure 2.4.

Pressure calibration: Pressure calibration is performed to determine the self - resistance of the rubber membrane to expansion. Before the pressure calibration, probe is taken out from the steel tube and calibration is performed in atmospheric pressure condition. A typical pressure calibration curve is given in Figure 2.4.

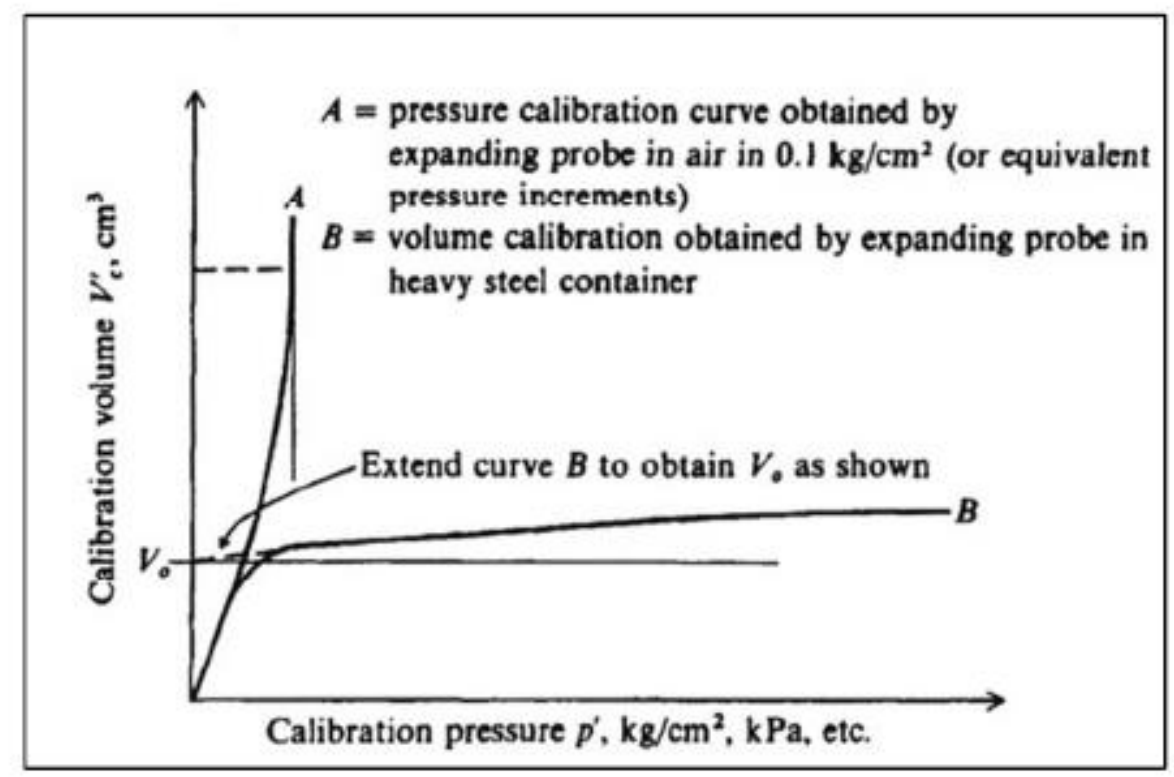

Figure 2.4 Calibration curves obtained before the PMT (Bowles (1997))

Calibration in the PMT is essential for obtaining accurate results from the test and if the calibrations are not carried out properly, and then the data obtained from the test can be considered as useless.

\subsubsection{Test results interpretation}

Plot the pressure-volume curve by entering corrected volume and corrected pressure on a coordinate system. Connect the points by a smooth curve. This curve is the corrected PMT curve which is shown in Figure 2.5 and used in to determine the PMT modulus. 


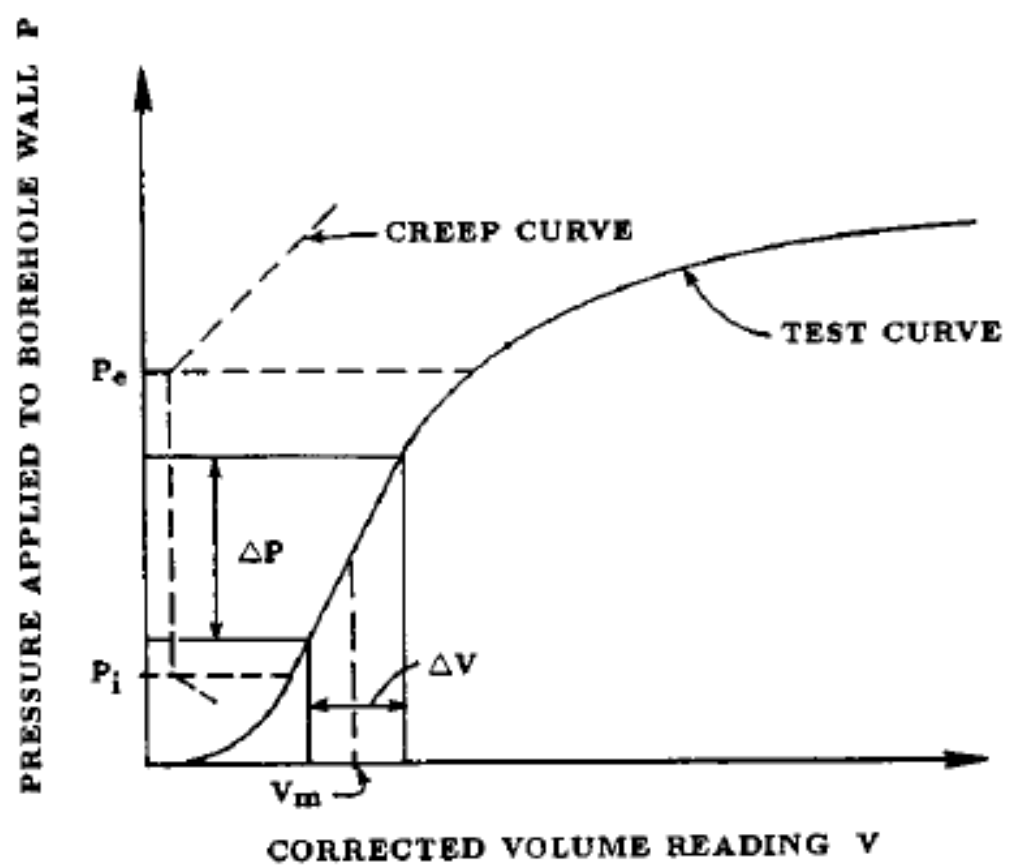

Figure 2.5 Typical pressuremeter test curve (ASTM (2000))

The PMT modulus is determined as follows.

$\mathrm{E}_{\mathrm{PMT}}=2(1+\mathrm{v})\left(V_{0}+V_{m}\right) \frac{\Delta P}{\Delta V}$

Where $\mathrm{E}_{\mathrm{PMT}}$ - Pressuremeter modulus

$v$ - Poisson's ratio

$V_{0}$ - Volume of the measuring portion of the uninflated probe at 0 volumes reading at ground surface

$V_{m}$ - Corrected volume reading in the center portion of the $\Delta \mathrm{V}$ volume increase

$\Delta \mathrm{P}$ - Corrected pressure increase in the center part of the straight line portion of the pressure - volume curve (see Fig 2.5)

$\Delta \mathrm{V}$ - Corrected volume increase in the center part of the straight line portion of the pressure - volume curve, corresponding to $\Delta \mathrm{P}$ pressure increase (see Fig 2.5) 
The PMT modulus can also be calculated as represented by the slope of the pressure vs radial strain curve along its linear portion is shown in Equation 2.8.

$\mathrm{E}_{\mathrm{PMT}}=(1+v)\left(p_{2}-p_{1}\right) \frac{\left[1+\left(\frac{\Delta R}{R_{0}}\right)_{2}\right]^{2}+\left[1+\left(\frac{\Delta R}{R_{0}}\right)_{1}\right]^{2}}{\left[1+\left(\frac{\Delta R}{R_{0}}\right)_{2}\right]^{2}-\left[1+\left(\frac{\Delta R}{R_{0}}\right)_{1}\right]^{2}}$

Where $\mathrm{p}$ and $\frac{\Delta R}{R_{0}}$ are the pressure and the corresponding radial strain recorded at the beginning (subscript 1) and at the end (subscript 2) of the linear portion of the PMT pressure vs radial strain curve respectively. The Poisson's ratio is given by $v$. For soils under drained conditions (ie, zero excess pore pressure) a Poisson's ratio of 0.33 is typically used, in which case the PMT modulus is designated as the Menard's modulus $\mathrm{E}_{\mathrm{PMT}}$ (Baguelin et al. (1978)).

Conventional limit pressure is determined as follows, the limit pressure $\left(\mathrm{P}_{\mathrm{L}}\right)$ is defined as the pressure where the probe volume reaches twice the original soil cavity volume, defined as the volume $V_{0}+V_{i}$ (see Fig 2.5) where $V_{i}$ is the corrected volume reading at the pressure where the probe made contact with the borehole. The volume reading at twice the original soil cavity volume is $\left(V_{0}+2 V_{i}\right)$. The limit pressure is usually not obtained by direct measurements during the test due to limitation in the probe expansion or excessively high pressure.

If the test was conducted to read sufficient plastic deformation, the limit pressure can be determined by a $1 / \mathrm{V}$ to $\mathrm{P}$ plot, as shown in Figure 2.6. Points from the plastic range of the test generally fall in an approximate straight line. The extension of this line to twice the original probe volume will give the limit pressure $\left(\mathrm{P}_{\mathrm{L}}\right)$ on the plot. 


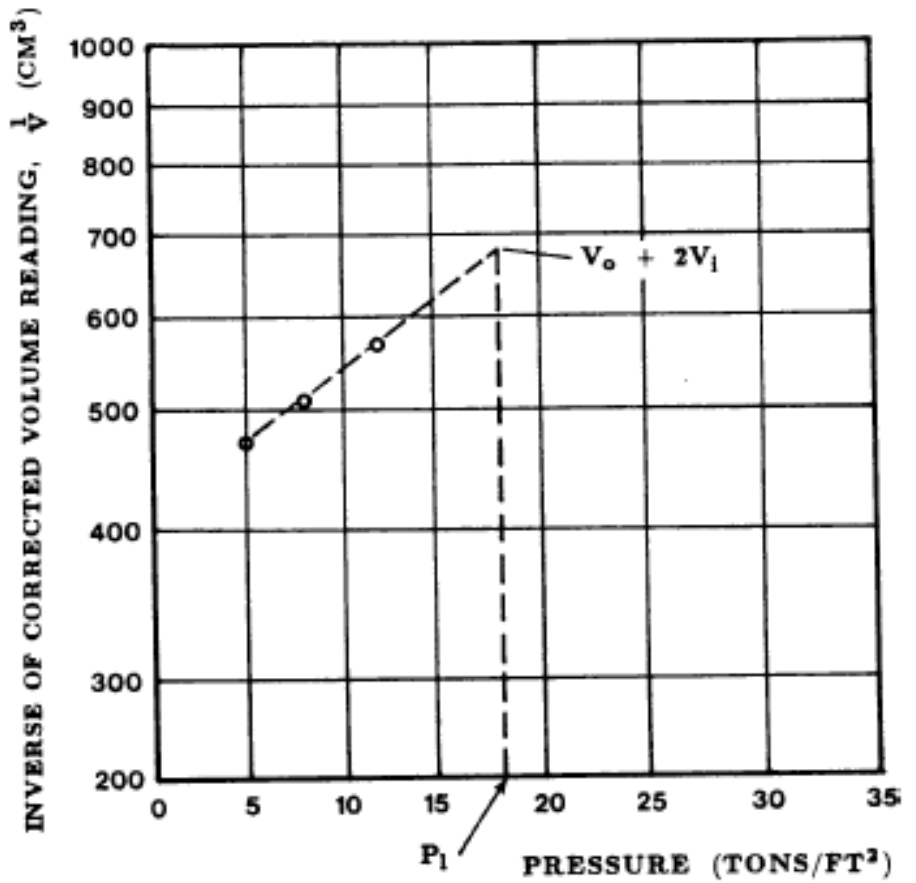

Figure 2.6 Determination of limit pressure from inverse of volume vs pressure curve (ASTM (2000))

\subsubsection{Application of these two parameters}

These two parameters are directly used in the Menard method (1965) to design the foundation. It is assumed that the ultimate bearing capacity is related to the pressure limit $\left(\mathrm{P}_{\mathrm{L}}\right)$ and the settlement is related to $\mathrm{PM}$ modulus $\left(\mathrm{E}_{\mathrm{PMT}}\right)$. The relationships have been shown below. The pressuremeter bearing capacity factor, $\mathrm{k}$, is defined by following equation.

$\mathrm{k}=\frac{q_{u}-\sigma_{v}}{P_{L}-\sigma_{h}}$

Where $q_{u}$ - Ultimate bearing capacity

$\sigma_{v}$ - Total vertical stress at the formation level

$\sigma_{h}$ - Total horizontal stress at the pressuremeter test level

The Menard method for settlement is based on a modulus of elasticity which is expressed in terms of the PM modulus, $\mathrm{E}_{\mathrm{PMT}}$. The settlement is given by following equation. 
$\mathrm{S}=\left(\frac{q-\sigma_{v}}{9 E_{P M T}}\right) \times$ a shape factor

Where $\mathrm{q}$ is the total bearing capacity

In this study the PMT was performed accordance with Procedure B, volume-controlled loading, as outlined in the ASTM D 4719-00, Pre-bored PMT was completed using a TEXAM unit.

\subsubsection{Pressuremeter test correlation in soils}

Pressuremeter test results are used for identification of the soils. Briaud (1992) developed an approximate common value of the pressuremeter parameters for clay and sand are given in Table 2.3 below.

Table 2.3 Approximate common values of the PMT parameters for clay and sand

\begin{tabular}{|c|c|c|c|c|c|c|}
\hline \multicolumn{7}{|c|}{ Sand } \\
\hline Soil type & Loose & \multicolumn{2}{|c|}{ Compact } & \multicolumn{2}{|r|}{ Dense } & Very dense \\
\hline $\mathrm{P}_{\mathrm{L}}(\mathrm{kPa})$ & $0-500$ & \multicolumn{2}{|c|}{$500-1500$} & \multicolumn{2}{|c|}{$1500-2500$} & $>2500$ \\
\hline $\mathrm{E}_{\mathrm{P}}(\mathrm{kPa})$ & $0-3500$ & \multicolumn{2}{|c|}{$3500-12000$} & \multicolumn{2}{|c|}{$12000-22500$} & $>22500$ \\
\hline \multicolumn{7}{|c|}{ Clay } \\
\hline Soil type & Soft & Medium & & & Very stiff & Hard \\
\hline $\mathrm{P}_{\mathrm{L}}(\mathrm{kPa})$ & $0-200$ & $200-400$ & 400 & & $800-1600$ & $>1600$ \\
\hline $\mathrm{E}_{\mathrm{P}}(\mathrm{kPa})$ & $0-2500$ & $2500-5000$ & 5000 & & $12000-25000$ & $>25000$ \\
\hline
\end{tabular}

\section{Yield pressure $\left(\boldsymbol{P}_{y}\right)$}

The yield pressure indicates the end of the linear pseudo - elastic deformation and the onset of plasticity. This yield pressure is useful in indicating beyond which pressure significant creep deformation may occur.

Two useful ratios, such as $\frac{E_{P M T}}{P_{L}}$ and $\frac{P_{L}}{P_{y}}$ can be used as a general guideline for soil identification, as follows (Briaud (1992)). 
For sand $7<\frac{E_{P M T}}{P_{L}}<12$

For clay $12<\frac{E_{P M T}}{P_{L}}$

Typical Menard PMT values are presented in the CFEM (2006) is shown in Table 2.4.

Table 2.4 Typical Menard PMT values

\begin{tabular}{|c|c|c|}
\hline Types of soil & Limit pressure $(\mathrm{kPa})$ & $\frac{E_{P M T}}{P_{L}}$ \\
\hline Soft clay & $50-300$ & 10 \\
\hline Firm clay & $300-800$ & 10 \\
\hline Stiff clay & $600-2500$ & 15 \\
\hline Loose silty sand & $100-500$ & 8 \\
\hline Silt & $200-1500$ & 7 \\
\hline Sand and gravel & $1200-5000$ & 8 \\
\hline Till & $1000-5000$ & 12 \\
\hline Old fil & $400-1000$ & 5 \\
\hline Recent fill & $50-300$ & 12 \\
\hline
\end{tabular}

For most soil types the ratio between the limit and the yield pressures may be expressed as (Briaud (1992)) $1.3<\frac{P_{L}}{P_{y}}<2.0$

\section{Deformation modulus of soils (Es)}

The slope of the PMT curve in the elastic range is defined as PMT modulus or Menard modulus $\left(\mathrm{E}_{\mathrm{P}}\right.$ or $\mathrm{E}_{\mathrm{M}}$ ) of the soil. PMT modulus is commonly used in geotechnical practice for foundation design because in many cases, the soil or rock shows elastic behavior before the failure conditions. This deformation modulus is one of the most important parameters in any geotechnical engineering projects. Its determination is not a fully solved theoretically. (Serrano and Romana(2002)). 
Expansion of a cylindrical cavity in an infinite elastic medium can be defined from cavity expansion theory (Lame (1852) cited in Baguelin et al. (1978)) as

$\mathrm{G}=\mathrm{V}\left(\frac{\Delta P}{\Delta V}\right)$

Where $\mathrm{G}$ - Shear modulus

V - Volume of the cavity

$\mathrm{P}$ - Pressure in the cavity

Shear modulus can be substituted with Young's modulus by using the equation obtained from theory of elasticity as follows.

$\mathrm{G}=\frac{E_{S}}{2(1+v)}$

The critical parameter in the equation above is the Poisson's ratio (v) which varies with the type of soil. For practical purposes a value of 0.33 is commonly selected for the Poisson's ratio. However, it is not appropriate to use for the undrained behavior of cohesive soils because volume of the soil does not change during the loading. Thus, saturated clay would have a Poisson's ratio of 0.45 . Since Menard accepted the $v$ as 0.33 in his original study, PMT modulus is calculated as follows.

$\mathrm{E}_{\mathrm{M}}=2(1+0.33) \mathrm{G}$

$\mathrm{E}_{\mathrm{M}}=2.66 \mathrm{G}$

Even though PMT modulus describes elastic behavior of a soil, it shall be used cautiously for design purposes because of the reasons listed below (Briaud (1992)).

(i) Strains on the soil are generally in large ranges which may not be realistic for the real loading conditions. 
(ii) Tensile stresses are likely to occur in the circumferential direction during the test. In spite the PM is a compression test, since the soil is known to be weak under tension; measured modulus is reduced due to tensile stresses.

(iii) Disturbances on the walls of borehole significantly reduce the modulus.

(iv) Aspect ratio (L/D) of the probe has been found to be a factor that can be affecting the modulus.

(v) Loading of the soil is relatively fast and in short time duration whereas the real superstructure loads act slowly during a larger time span.

(vi) PMT modulus is a horizontal modulus. For vertical loading on the soil vertical modulus should be considered which differs from horizontal modulus especially in anisotropic soils.

As above reasons, the PMT modulus can be considered as a relatively low value compared with Young's modulus. Menard (1975) proposed that the PMT modulus should be divided by a correction factor $\alpha$ in order to relate with Young's modulus (Briaud (1992)). Typical $\alpha$ value is proposed by Menard for different types of soil and rock are given in Table 2.5.

Table 2.5 Typical Menard $\alpha$ factors (Briaud (1992))

\begin{tabular}{|c|c|c|c|c|c|c|c|c|c|c|}
\hline \multirow[b]{2}{*}{$\begin{array}{l}\text { Soil } \\
\text { type }\end{array}$} & \multicolumn{2}{|c|}{ Peat } & \multicolumn{2}{|c|}{ Clay } & \multicolumn{2}{|c|}{ Silt } & \multicolumn{2}{|c|}{ Sand } & \multicolumn{2}{|c|}{$\begin{array}{l}\text { Sand and } \\
\text { gravel }\end{array}$} \\
\hline & $E / p_{i}^{*}$ & $\alpha$ & $E / p_{i}^{*}$ & $\alpha$ & $E / p_{i}^{*}$ & $\alpha$ & $E / p_{i}^{*}$ & $\alpha$ & $E / p_{L}^{*}$ & $\alpha$ \\
\hline $\begin{array}{l}\text { Over- } \\
\text { consolidated }\end{array}$ & & & $>16$ & 1 & $>14$ & $2 / 3$ & $>12$ & $1 / 2$ & $>10$ & $1 / 3$ \\
\hline $\begin{array}{l}\text { Normally } \\
\text { consolidated }\end{array}$ & $\begin{array}{c}\text { For } \\
\text { all } \\
\text { values }\end{array}$ & 1 & $9-16$ & $2 / 3$ & $8-14$ & $1 / 2$ & $7-12$ & $1 / 3$ & $6-10$ & $1 / 4$ \\
\hline $\begin{array}{l}\text { Weathered } \\
\text { and/or } \\
\text { remoulded }\end{array}$ & & & $7-9$ & $1 / 2$ & & $1 / 2$ & & $1 / 3$ & & $1 / 4$ \\
\hline Rock & & ture & & & $\begin{array}{l}\text { Other } \\
\alpha=1 / 2\end{array}$ & & & $\begin{array}{l}\text { ghtly } \\
\text { remel }\end{array}$ & $\begin{array}{l}\text { actured } \\
\text { weathe } \\
2 / 3\end{array}$ & \\
\hline
\end{tabular}


The pressuremeter modulus has been related empirically to the elastic modulus of the soil as $\mathrm{E}_{\mathrm{M}} / \mathrm{E}=\alpha$, (Menard (1995)), in which $\alpha$ is termed by Menard as the rheological coefficient and has a value between 0 and 1 .

\section{Elastic Young's modulus of soil}

Soil Young's modulus (E), commonly referred to as soil elastic modulus, is an elastic soil parameter and a measure of soil stiffness. It is define as the ratio of the stress along an axis over the strain along that axis in the range of elastic soil behavior. The elastic modulus is often used for estimation of soil settlement and elastic deformation analysis. Soil elastic modulus can be estimated from laboratory or in-situ tests or based on correlation with other soil properties. In laboratory, it can be determined from triaxial test or indirectly from oedometer test. On field, it can be estimated from SPT, CPT and PMT.

Typical Young's modulus was recommended for different types of soils by Bowles (1996) were shown in Table 2.6.

Table 2.6 Typical Young's modulus for different types of soils (Bowles (1996))

\begin{tabular}{|c|c|c|}
\hline Soil type & & Young's modulus (Mpa) \\
\hline \multirow[t]{5}{*}{ Clay } & Very stiff & $2-15$ \\
\hline & Soft & $5-25$ \\
\hline & Medium & $15-50$ \\
\hline & Hard & $50-100$ \\
\hline & Sandy & $25-250$ \\
\hline \multirow[t]{4}{*}{ Sand } & Silty & $5-20$ \\
\hline & Loose & $10-25$ \\
\hline & Dense & $50-81$ \\
\hline & Silt & $2-20$ \\
\hline \multirow[t]{3}{*}{ Glacial till } & Lose & $10-150$ \\
\hline & Dense & $150-720$ \\
\hline & Very dense & $500-1440$ \\
\hline
\end{tabular}




\subsubsection{CORRELATION BETWEEN SPT-N WITH PMT PARAMETERS}

Estimation from SPT-N value of the two pressuremeter parameters such as pressuremeter modulus $\left(\mathrm{E}_{\mathrm{PMT}}\right)$ and pressure limit $\left(\mathrm{P}_{\mathrm{L}}\right)$ has been studied by a few researchers in the past (Briaud (1992) and Ohya et al. (1982)). Attempted correlations have usually been weak because of the differences in the methods and uncertainties involved in the tests. Even though, they are widely used in practice to get an idea about the level of the geotechnical parameters used in the design. One linear relationship with zero intercept was proposed by Briaud (1992) for the $\mathrm{E}_{\mathrm{PMT}}$ and $\mathrm{P}_{\mathrm{L}}$ from SPT-N value for sands (Figure 2.7 and Figure 2.8), while one non-linear relationship was proposed by Ohya et al. (1982) on the basis of data obtained from alluvial and dilluvial deposits in Japan (Figure 2.9 and Figure 2.10). Both researches indicated the wide scatter of data.

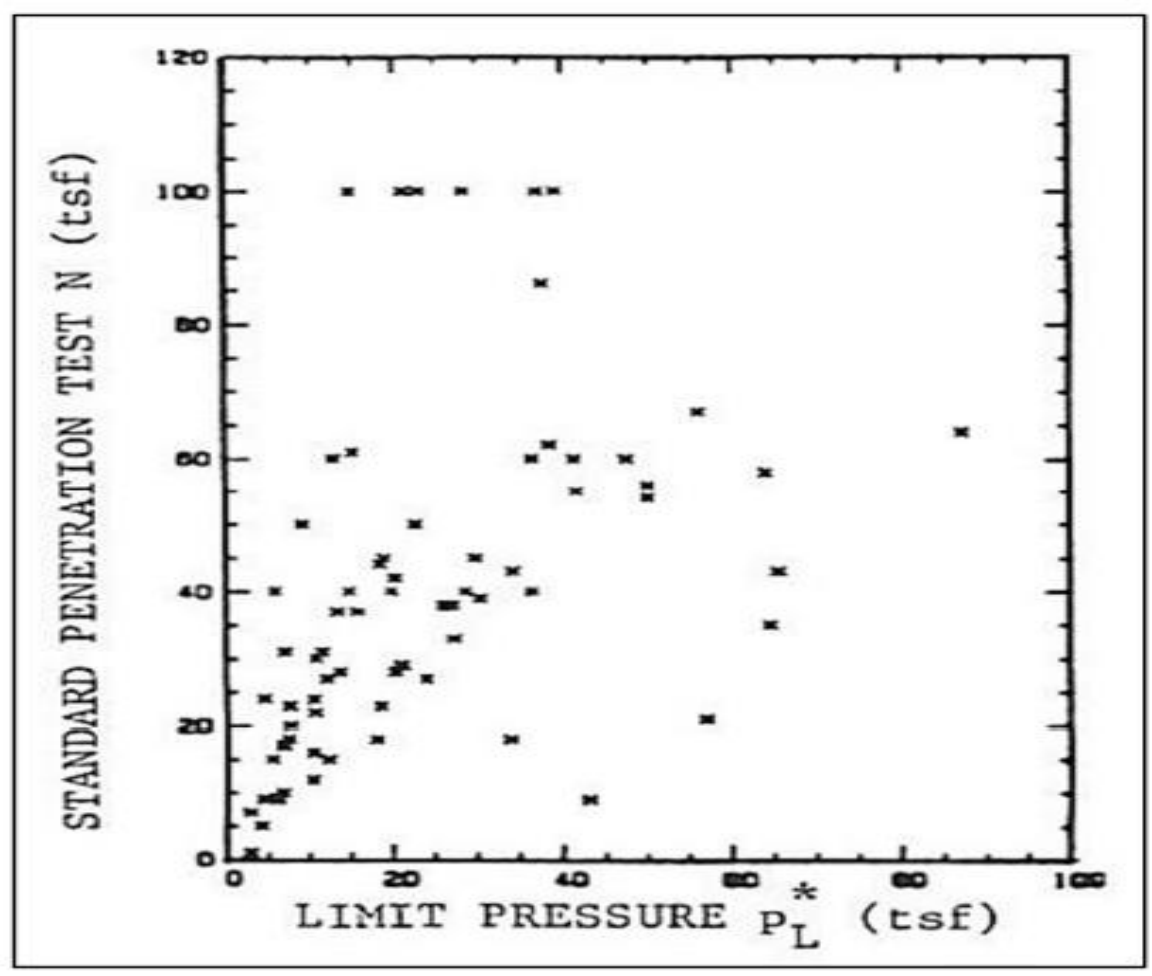

Figure 2.7 Correlation between SPT N and limit pressure $\left(\mathrm{P}_{\mathrm{L}}\right)($ Briaud (1992)) 


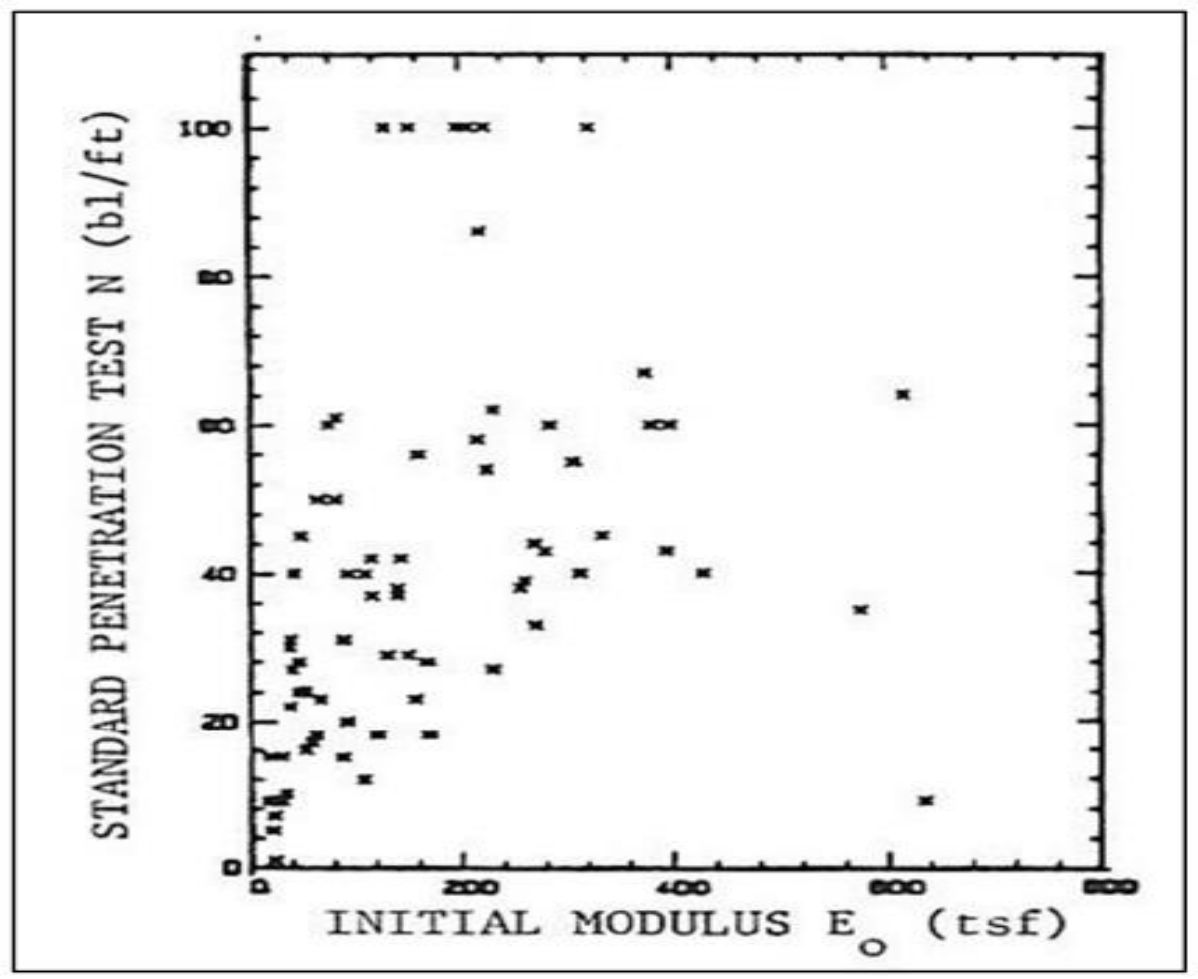

Figure 2.8 Correlations between SPT N and Ep (Briaud (1992))

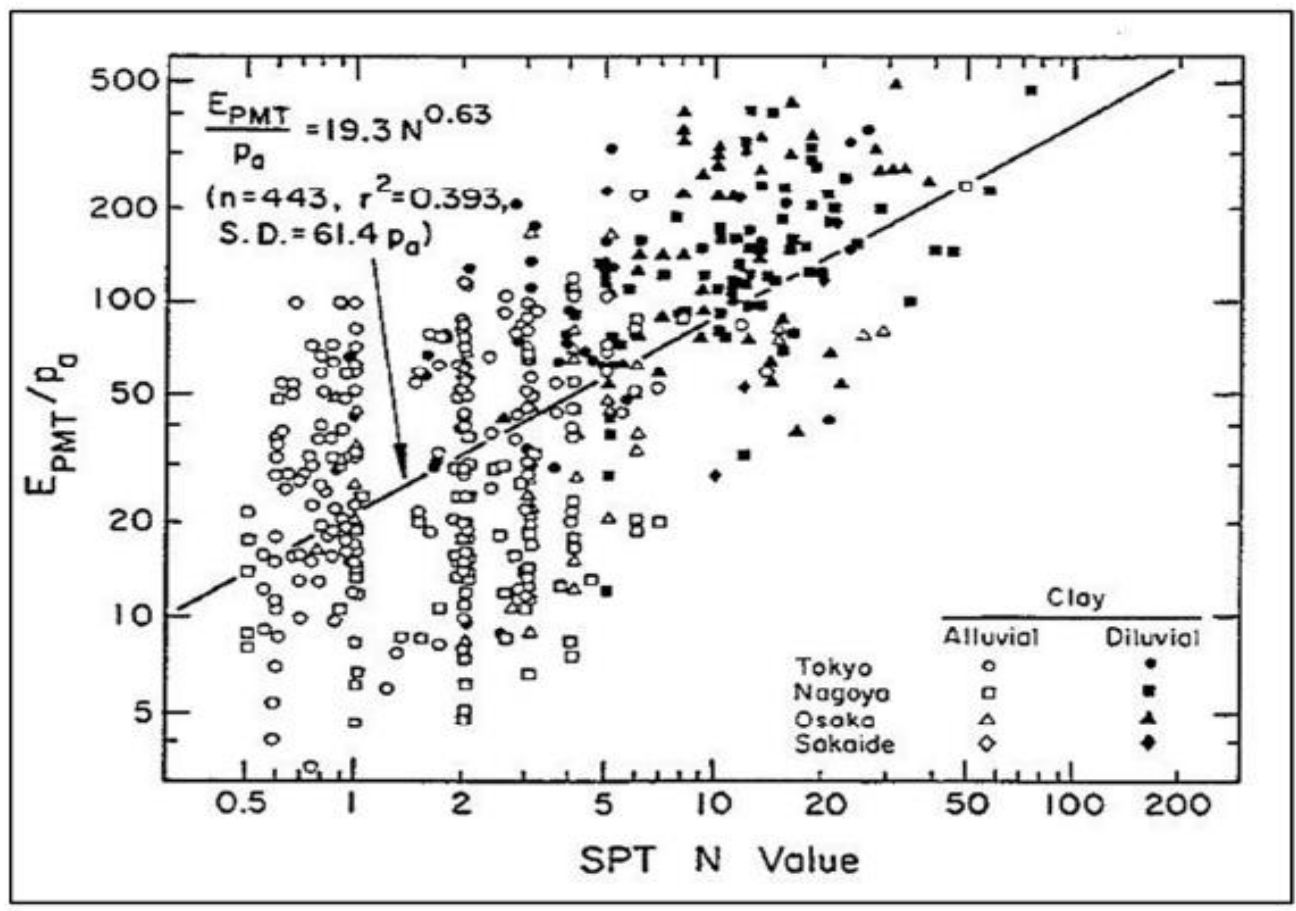

Figure 2.9 Correlation between SPT N and EPMT for clays (Ohya et al. (1982)) 


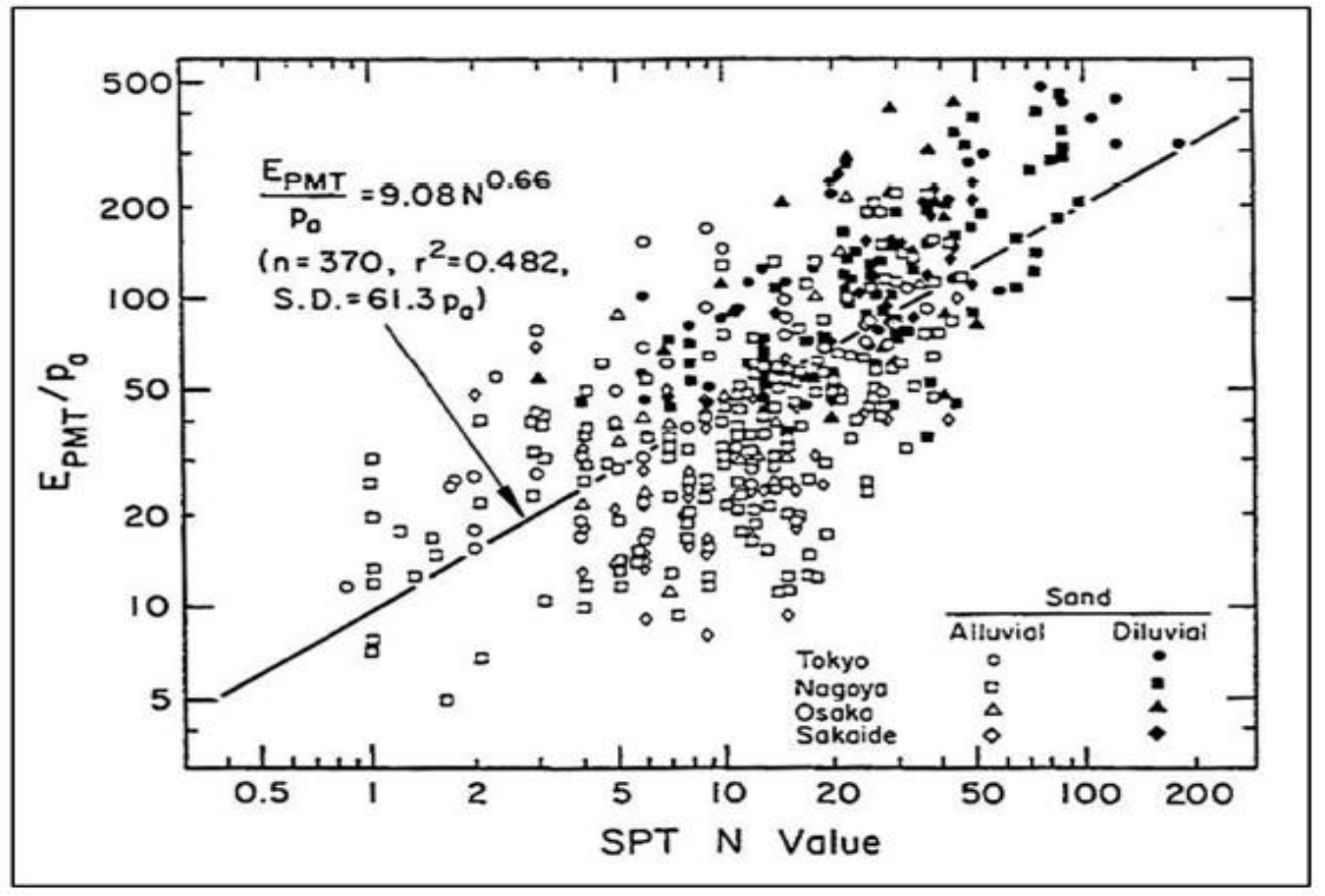

Figure 2.10 Correlation between SPT N and $\mathrm{E}_{\mathrm{PMT}}$ for sands (Ohya et al. (1982))

Further nonlinear relationships between SPT and both $\mathrm{E}_{\mathrm{PMT}}$ and $\mathrm{P}_{\mathrm{L}}$ for sand and clay were proposed by Bozbey (2010) for data measured during an extensive geotechnical investigation conducted in Istanbul, Turkey. In glacial tills, there is a study conducted by Yagiz (2008), with a linear relationship with an intercept between the corrected SPT-N values $\left(\mathrm{N}_{\text {cor }}\right)$ with both $\mathrm{E}_{\mathrm{PMT}}$ and $\mathrm{P}_{\mathrm{L}}$ in Gumusler country, $10 \mathrm{~km}$ north of the city of Denizli, Turkey.

\subsection{PREVIOUS RESEARCH ON NUMERICAL SIMULATIONS OF THE PMT}

\subsubsection{GEOMETRY AND BOUNDARY CONDITION OF THE MODEL}

The PMT was simulated by an axisymmetric model in the Schanz et al. (2000), Michel et al. (2000), Jacques (2007), Rita (2008), Levasseur et al. (2009), Malecot et al. (2009), Plaxis 2D (2012), Monnet (2012), Sedran et al. (2013), Fawaz et al. (2014). The geometry sizes, diameter of $1.2 \mathrm{~m}$ and height of $1.5 \mathrm{~m}$ were used by Schanz et al. (2000), Malecot et al. (2009) and Plaxis 
2D (2012). The Levasseur et al. (2009) used a diameter of $6 \mathrm{~m}$ and height of $5 \mathrm{~m}$ in their geometry model. Jacques (2007) and Monnet (2012) used a geometry model with diameters of 5 and $10 \mathrm{~m}$ respectively and $2 \mathrm{~m}$ of height above the midpoint of the probe. But both of them did not mention the dimensions below the probe. Fawaz et al. (2014) used $7 \mathrm{~m}$ of diameter and $7 \mathrm{~m}$ of height below the probe but did not mention the dimensions above the probe. The Michel et al. (2000), Rita (2008) and Sedran et al. (2013) did not define the geometry sizes of their model.

In the boundary conditions, bottom of the model was vertical fixity and both vertical faces of the model were horizontal fixity as used by Schanz et al. (2000) and Plaxis 2D (2012). Bottom of the model was total fixity (both horizontal and vertical) and both vertical faces of the model were horizontal fixity as used by Levasseur et al. (2009), Malecot et al. (2009) and Fawaz et al. (2014). Bottom of the model was vertical fixity and right side of the model was free in both directions (horizontal and vertical) and the left side of the model was horizontal fixity as used by Jacques (2007) and Monnet (2012). The Michel et al. (2000), Rita (2008) and Sedran et al. (2013) once again did not define the boundary conditions of their model.

Each authors used different geometry dimensions and boundary conditions. The geometry models with dimensions and boundary conditions that were available from the literature are shown in Figure 2.11 to Figure 2.13.

To simulate the test at a deeper elevation, a vertical stress was applied at the top of the mesh (load B). The pressuremeter applies a radial stress (load A) at the lower part of the borehole with an imposed stress at each loading steps as stated in the Jacques (2007). But in the Plaxis 2D (2012) and Schanz et al. (2000) load A was applied as a vertical surcharge stress and load B was applied in a radial stress on the probe. In the Levasseur et al. (2009) load B was used for both radial stress and overburden vertical stress. 

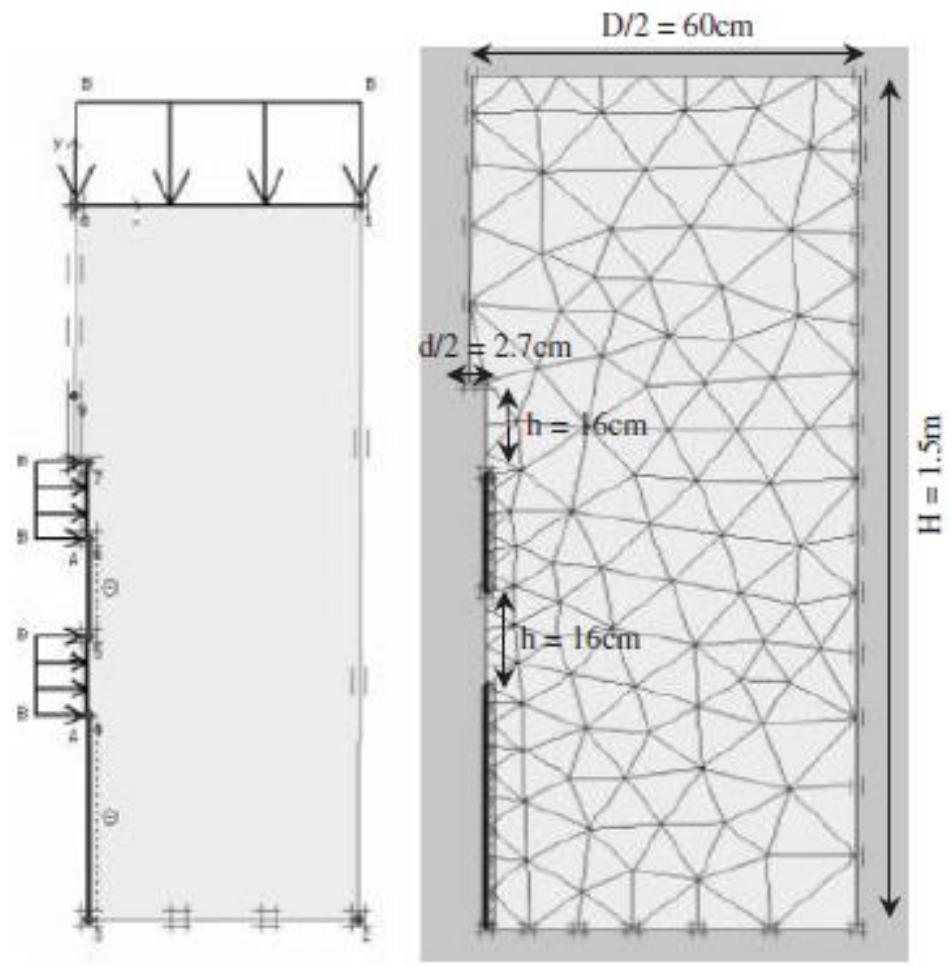

Figure 2.11 The 2D axisymmetric model and associated mesh diagram (Malecot et al. (2009))

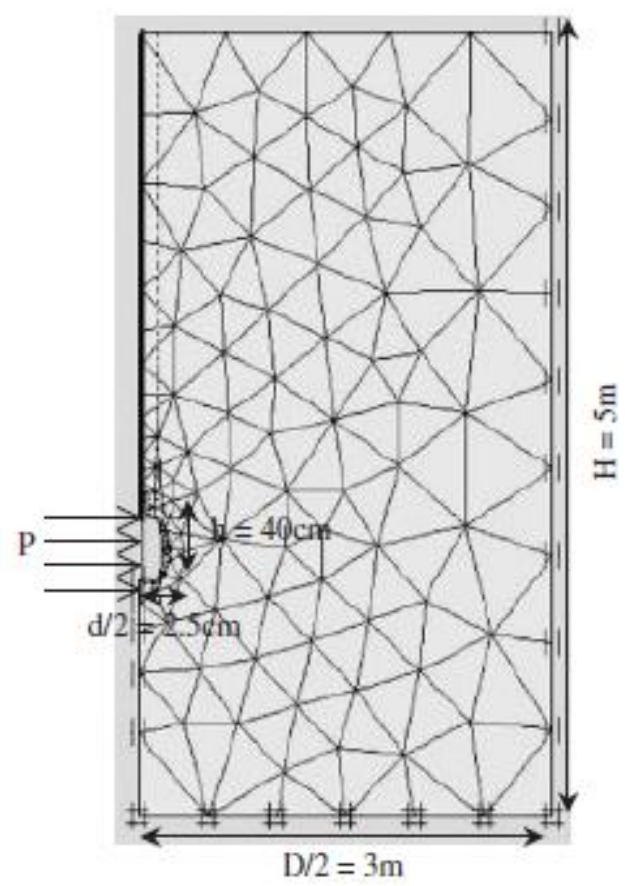

Figure2.12 The 2D axisymmetric model and associated mesh diagram (Levasseur et al. (2009)) 


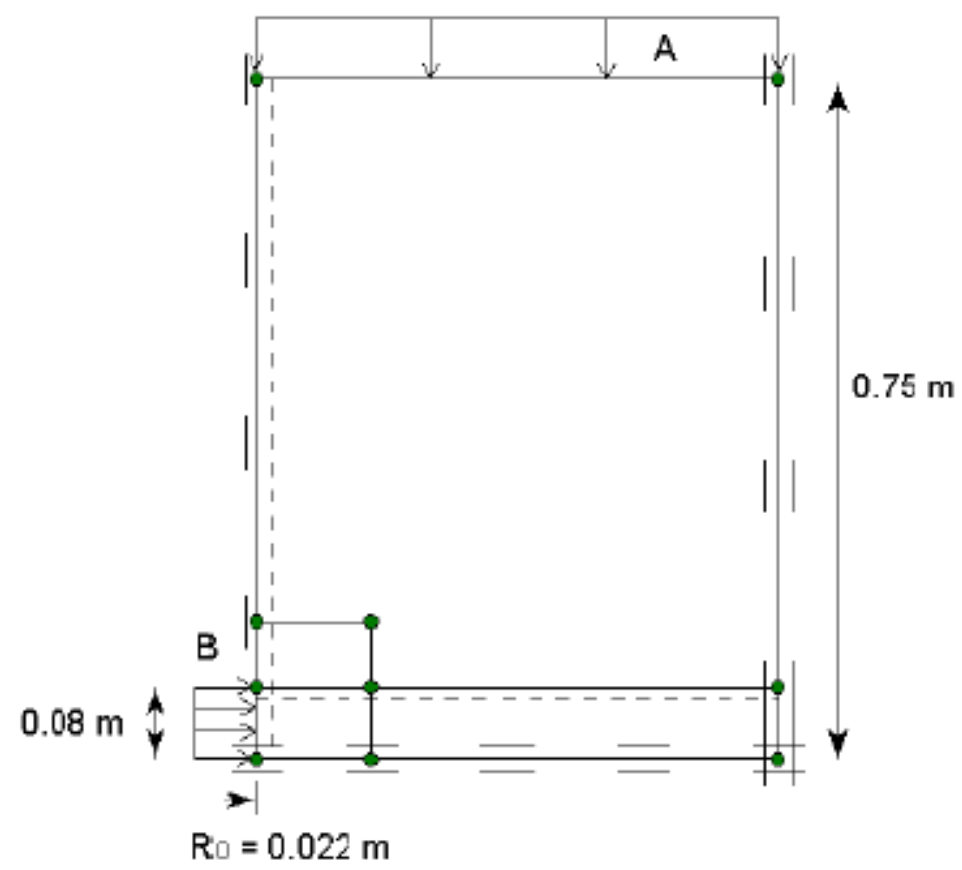

Figure 2.13 Geometry model for PMT (Plaxis 2D (2012))

\subsubsection{PROB LENGTH (L) TO DIAMETER (D) RATIO (L/D RATIO)}

The PMT was modeled as an axisymmetric problem. In this case, where L/D ratio is higher than 6 , the test results were similar to those obtain considering plain strain conditions (Houlsby and Carter (1993)). The L/D ratio used by Waschkowski (1976), Schanz et al. (2000), Jacques (2007), Rita (2008), Levasseur et al. (2009), Plaxis 2D (2012), Monnet (2012) and Sedran et al. (2013) were 6.6, 2.9, 7.5, 6.7, 8, 3.6, 6 and 6.5 respectively. The Michel et al. (2000), Malecot et al. (2009), and Fawaz et al. (2014) did not mention the L/D ratio in their study.

\subsubsection{TYPE OF MODEL}

A lot of soil constitutive models can be found in the literature that permits to deal with a large variety of geotechnical problems. Nevertheless, these constitutive models have, most of the time, a large number of parameters whose values are not obvious to identify. Classically, the parameters' values are estimated from laboratory tests on small samples or from in- situ tests. 
Unfortunately, parameters estimated from laboratory test were difficult because of the weak representative of the soil sample size and the perturbations imposed to the samples during its extraction. Likewise, in-situ tests do not allow the direct identification of the constitutive parameters of the soil layers.

In the literature, a constitutive model was introduced which was formulated in the frame work of classical theory of plasticity. Instead of using Hooke's single stiffness model with linear elasticity in combination with an ideal plasticity according to Mohr-Coulomb (M-C). A new constitutive formulation using a double stiffness model for elasticity in combination with isotropic strain hardening was used. Summarizing the existing double stiffness models the most dominant type of model is the Cam Clay model (Hashiguchi (1985) and Hashiguchi (1993)). To describe the non-linear stress strain behavior of soil, beside the Cam Clay model the pseudo elastic (hypo-elastic) type of model has been developed. There an Hookean relationship was assumed between increments of stress and strain and non-linearity was achieved by means of varying Young's modulus. The Duncan Chang (1970) model known as hyperbolic model captures soil behavior in a very tractable manner on the basis of only two stiffness parameters and it was very much appreciated among consulting geotechnical engineers. The major inconsistency of this type of model which was the reason why it was not accepted by scientists is that, in contrast to the elasto - plastic type of model, a purely hypo elastic model cannot consistently distinguish between loading and unloading. In addition the model was not suitable for collapse load computation in the fully plastic range. These restrictions will be overcome by formulating a model in an elasto - plastic frame work in the constitutive models. The hardening soil model supersedes the Duncan Chang model. Firstly by using the theory of plasticity rather than theory of elasticity and secondly by including soil dilatancy and thirdly by introducing a yield cap.

In case of simulation of PMT, the M-C model was used as a material model by Schanz et al. (2000), Levasseur et al. (2009), Malecot et al. (2009), Monnet (2012) and Fawaz et al. (2014). The hardening soil model (HSM) was used by Michel et al. (2000), Rita (2008), Plaxis 2D (2012) and Sedran et al. (2013). Jacques (2007) used Tresca model as a material model in the simulation study. 


\subsubsection{DEFORMED MESH AND ANALYSIS}

In the PMT analysis, 15 nodes triangular elements were used in the mesh by Jacques (2007) and Rita (2008). The deformed geometry of the PMT after the simulation from Schanz et al. (2000), Rita (2008), Levasseur et al. (2009), Malecot et al. (2009), Plaxis 2 D (2012) and Fawaz et al. (2014) are shown in Figure 2.14 to Figure 2.19 respectively.

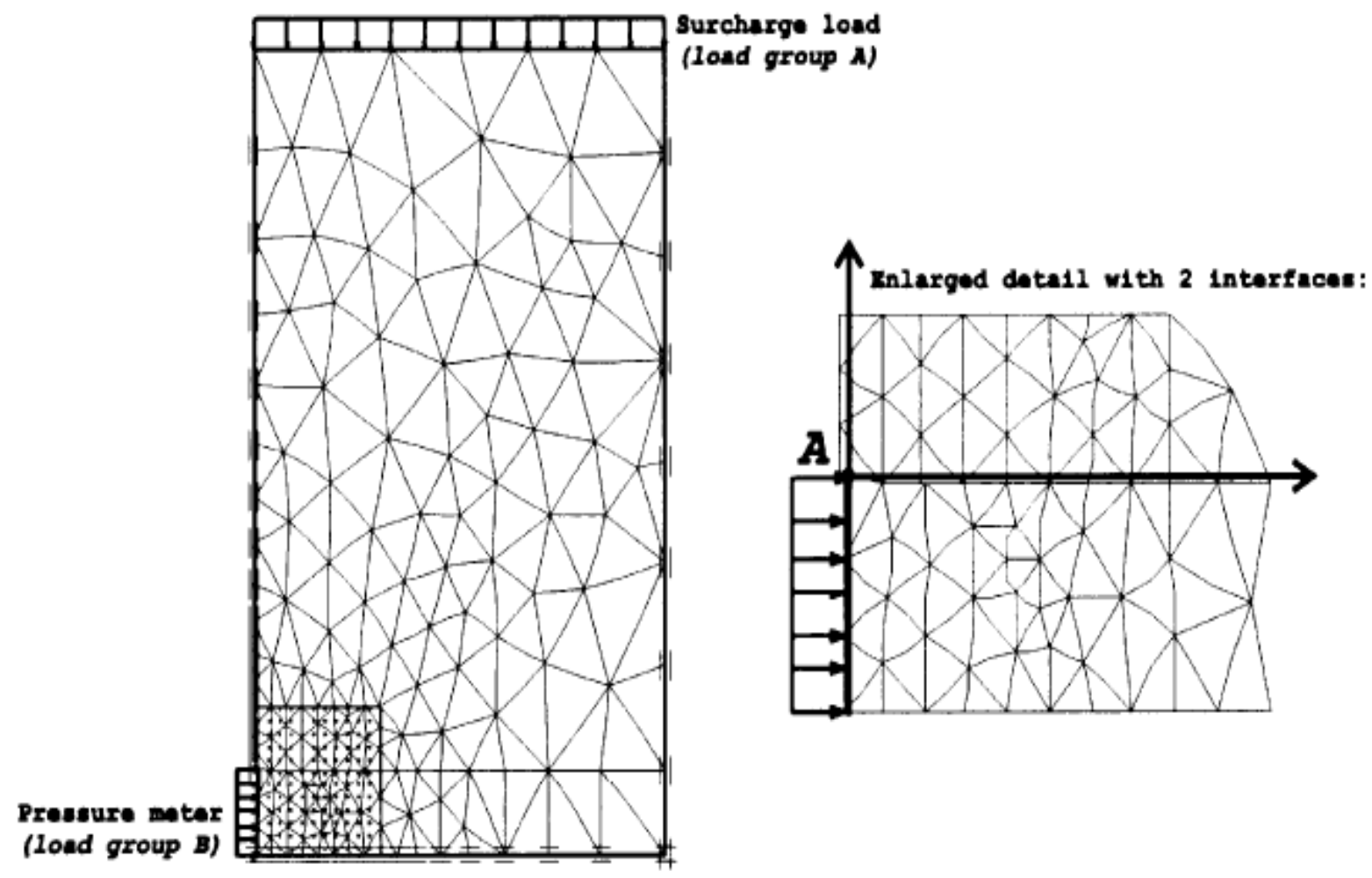

Figure 2.14 FE discretization of the calibration chamber (Schanz et al. (2000)) 

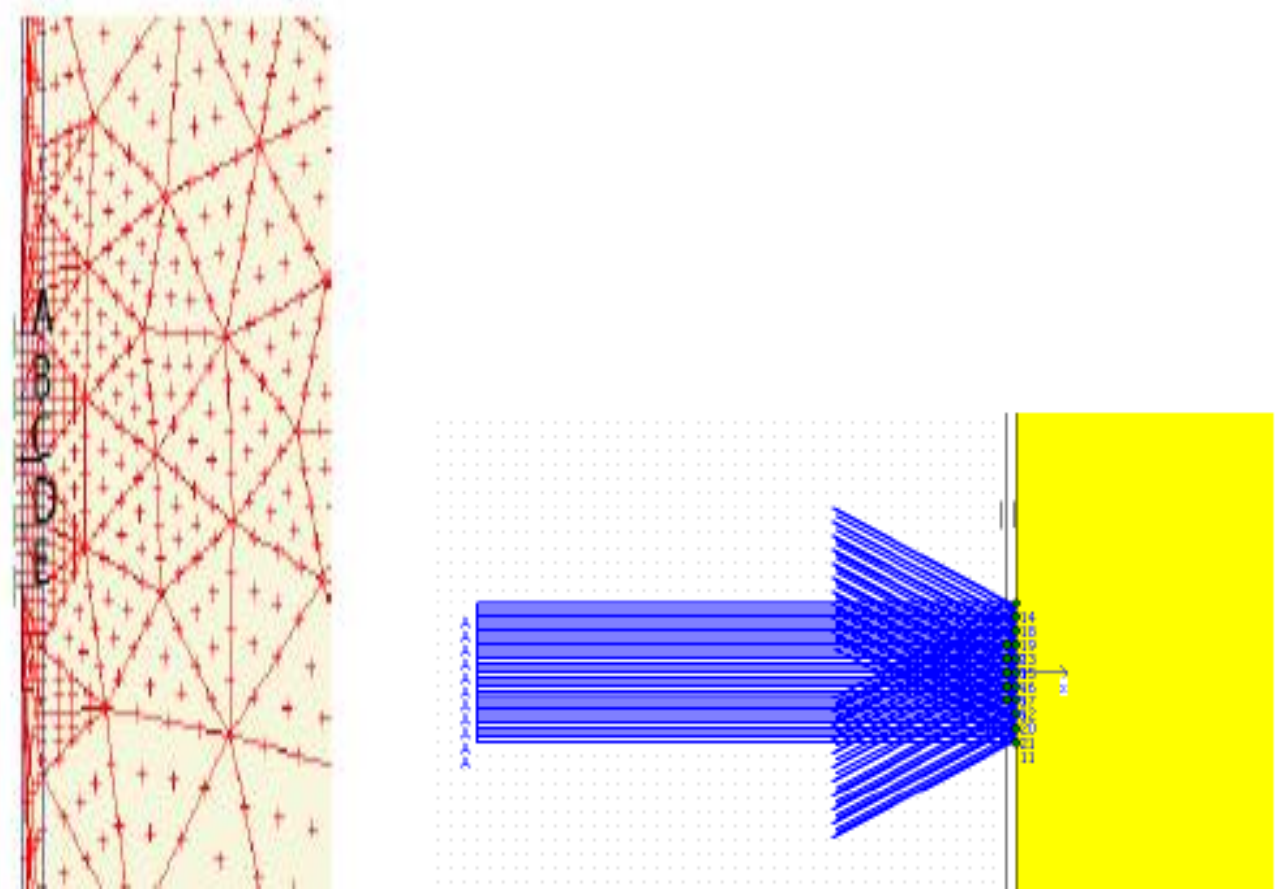

Figure 2.15 Points from which the displacements are read (Rita (2008))

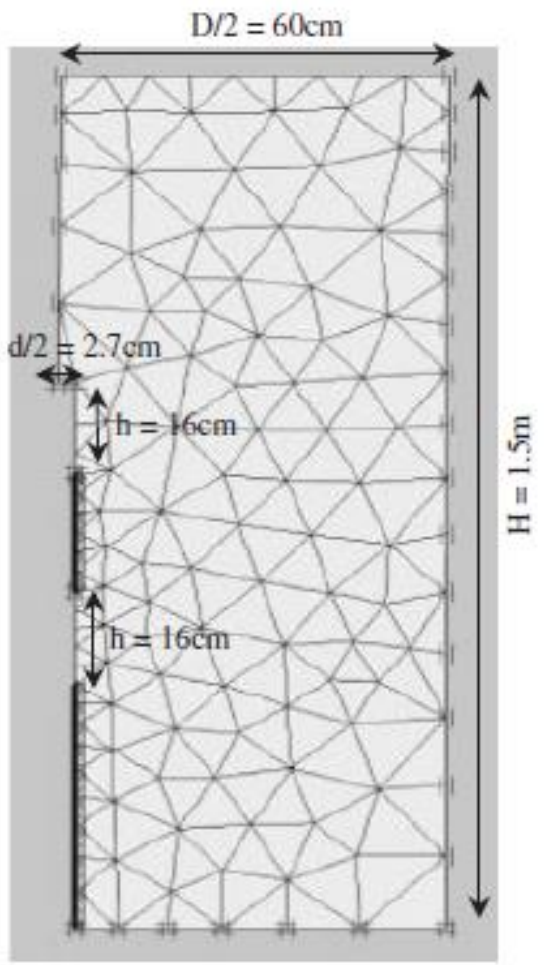

Figure 2.16 The 2D axisymmetric model and associated mesh diagram (Malecot et al. (2009)) 


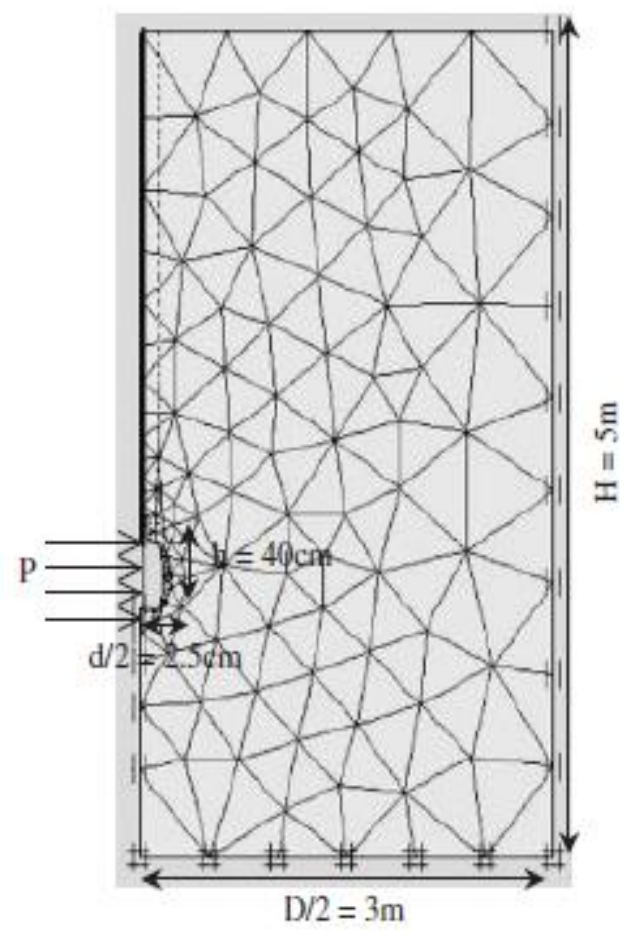

Figure 2.17 The 2D axisymmetric model and associated mesh diagram (Levasseur et al. (2009))

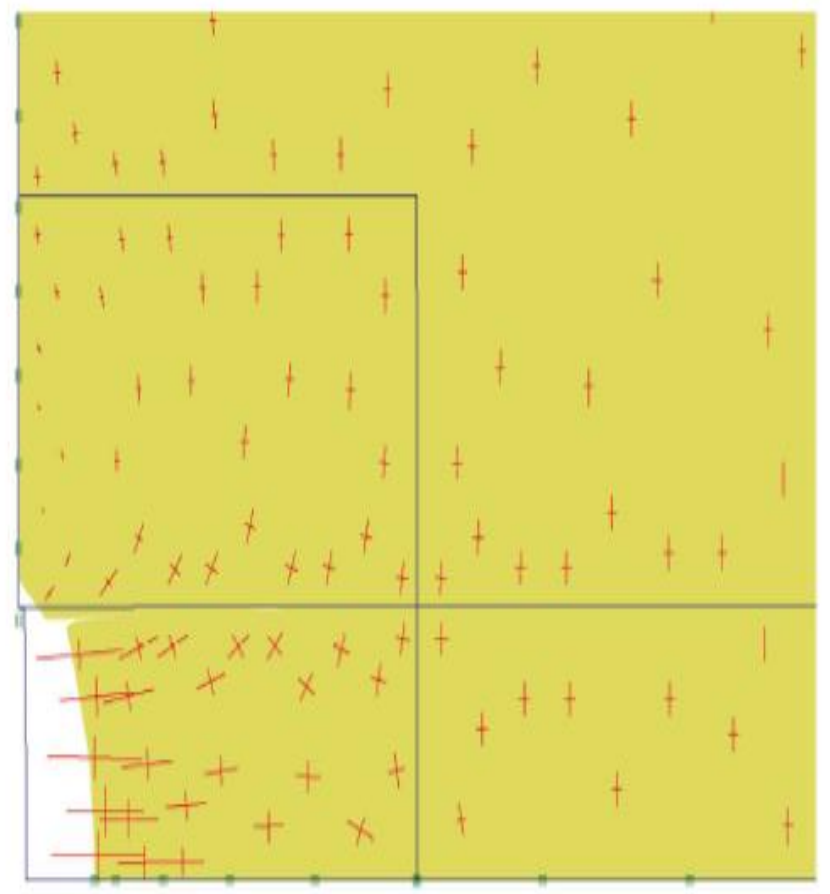

Figure 2.18 Deformed geometry of the PMT (Plaxis (2012)) 


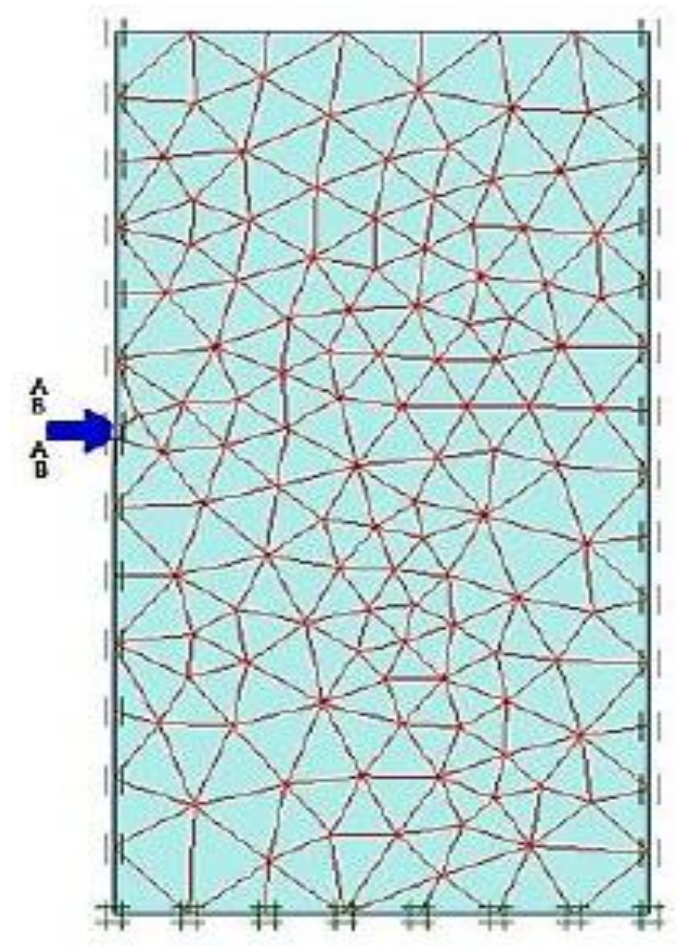

Figure 2.19 Geometry of axisymmetric model (Fawaz (2014))

In this FE analysis of PMT, a vertical interface along the shaft of the PMT borehole and a horizontal interface just above the PM were introduced to allow for a discontinuity in horizontal displacement in the Plaxis 2D (2012). The vertical interface along the borehole face was introduced in the Levasseur et al. (2009) and Malecot et al. (2009).

\subsubsection{ANALYSIS RESULTS AND GRAPHS}

The numerical results and pressuremeter test data were plotted and compared, which were shown in Figure 2.20 to Figure 2.23 from Schanz et al. (2000), Rita (2008), Plaxis 2D (2012) and Fawaz (2014) respectively. Graphs were drawn for pressure vs volumetric strain. The volumetric strain was calculated from the original radius $R_{0}$ and lateral expansion $U_{x}$ of the PM. The volume change cannot directly be measured from Plaxis and was calculated from Equation 2.15.

$\frac{\Delta V}{V_{0}}=\frac{\left(R_{0+} U_{x}\right)^{2}-\left(R_{0}\right)^{2}}{\left(R_{0}\right)^{2}}$ 


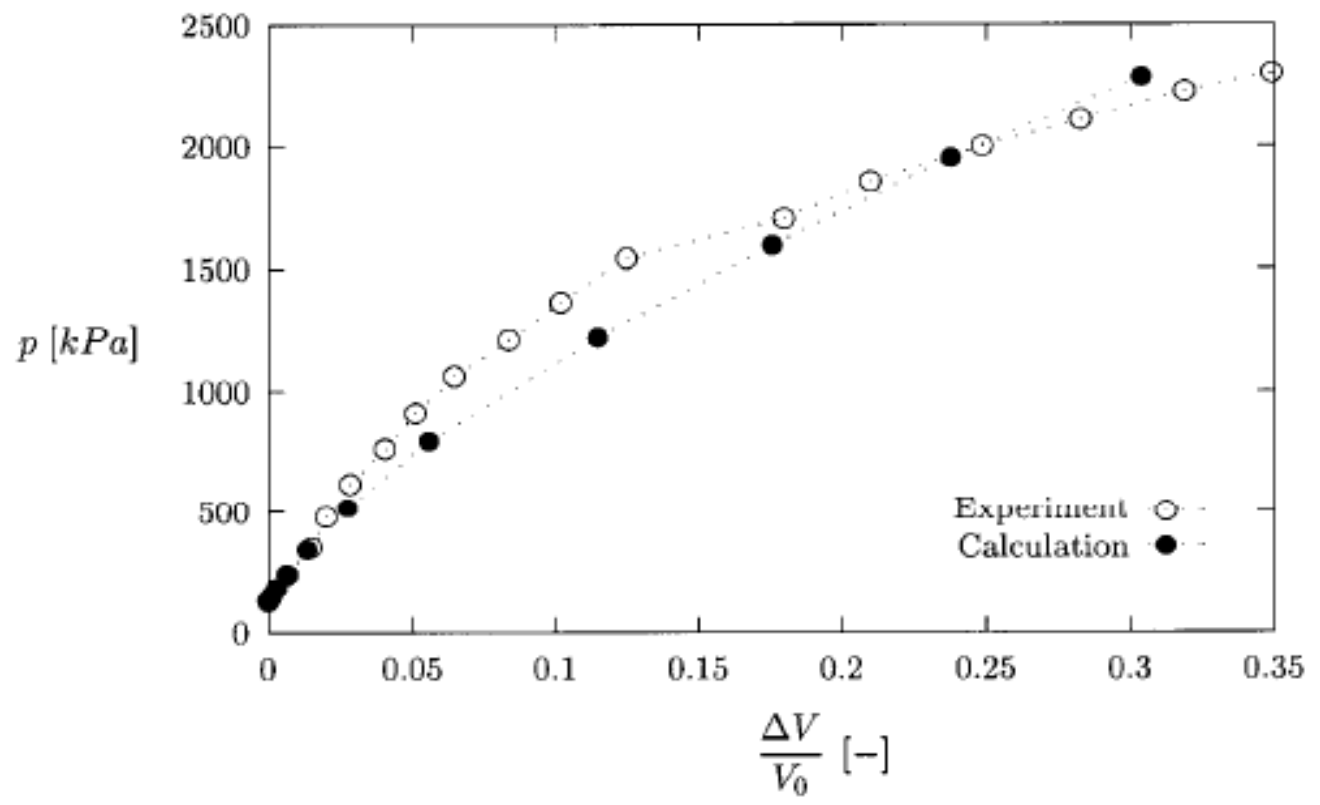

Figure 2.20 Comparison between experimental and numerical results of the PMT (Schanz et al. (2000))

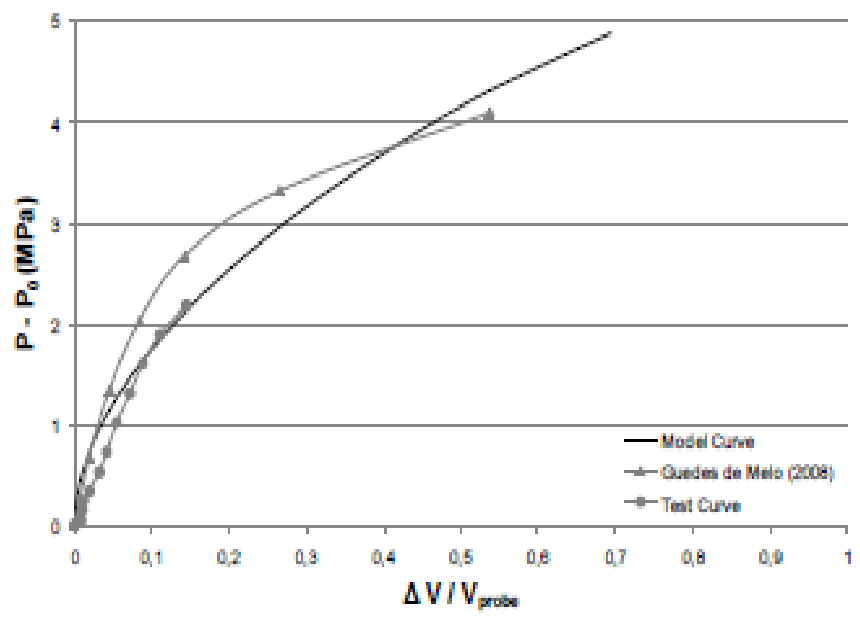

Figure 2.21 Model and test curves at $500 \mathrm{kPa}$ of effective vertical stress (Rita (2008)) 


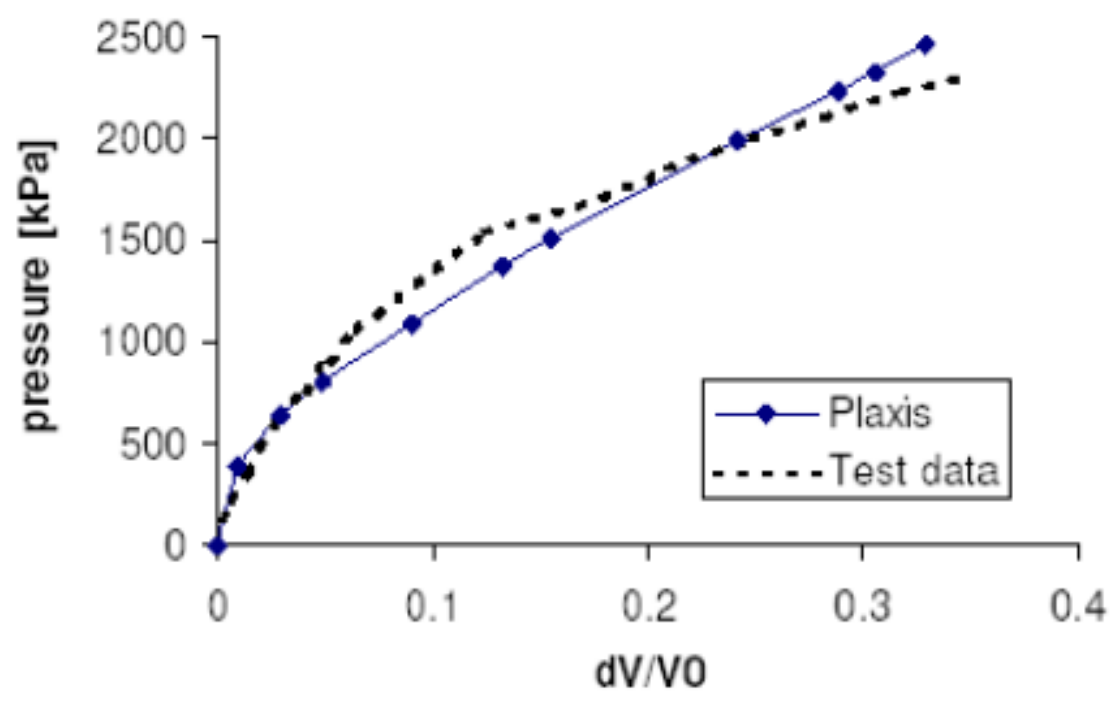

Figure 2.22 Comparison of numerical results and PMT data (Plaxis (2012))

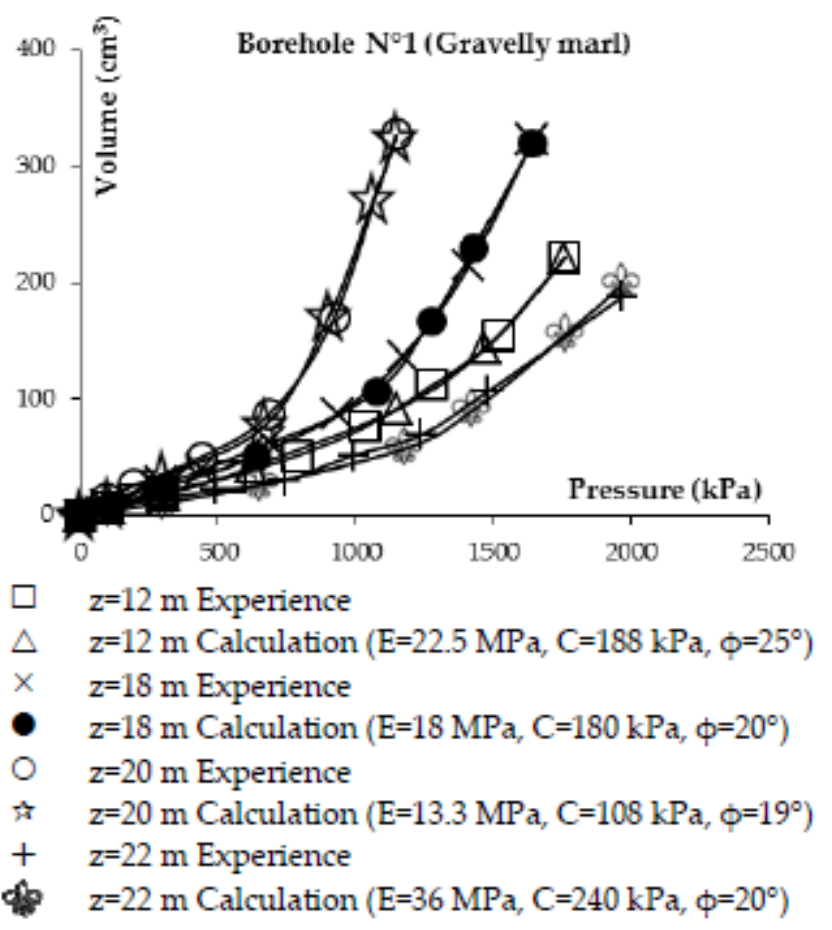

Figure 2.23 Experimental and numerical pressure-volume curves at different depth (Fawaz (2014)) 


\subsubsection{COMPARISON OF PM AND YOUNG MODULUS}

The pressuremeter modulus $\left(\mathrm{E}_{\mathrm{M}}\right)$ and its comparison to the Young modulus (E) of soil were performed by Sedran et al. (2013) and Fawaz et al. (2014). Pressuremeter testing provides stressstrain data for pseudo-elastic and elastic-plastic ranges of soil deformation. The analysis of stress and strain changes in a soil mass due to PMT loading is based in the theory of cavity expansion as it pertains to an infinitely long cylinder expanding into an infinite soil range. Assuming uniform isotropic and linear elastic soil behavior, the elastic property of the soil is represented by the pressuremeter modulus $\left(\mathrm{E}_{\mathrm{M}}\right)$ (Briaud (1992)), and is calculated with the following expression.

$\mathrm{E}_{\mathrm{M}}=(1+v)\left(p_{2}-p_{1}\right) \frac{\left[1+\left(\frac{\Delta R}{R_{0}}\right)_{2}\right]^{2}+\left[1+\left(\frac{\Delta R}{R_{0}}\right)_{1}\right]^{2}}{\left[1+\left(\frac{\Delta R}{R_{0}}\right)_{2}\right]^{2}-\left[1+\left(\frac{\Delta R}{R_{0}}\right)_{1}\right]^{2}}$

Where $\mathrm{p}$ and $\frac{\Delta R}{R_{0}}$ are the pressure and the corresponding radial strain recorded at the beginning (subscript 1) and at the end (subscript 2) of the linear portion of the PMT pressure vs radial strain curve respectively. The Poisson's ratio is given by $v$. For soils under drained conditions (ie, zero excess pore pressure) a Poisson's ratio of 0.33 is typically used, in which case the pressuremeter modulus is designated as the Menard's modulus $\mathrm{E}_{\mathrm{M}}$ (Baguelin et al. (1978)).

\subsubsection{CONVENTIONAL LIMIT PRESSURE}

The numerical validation of an elastoplastic formulation of the conventional limit pressure measured with the pressuremeter test in cohesive soil studied by Jacques (2007). An elastoplastic presssuremeter theory was used to determine the conventional limit pressure. Then conventional limit pressure was computed by using Plaxis to check the validity of the theoretical results. In the Plaxis, the Tresca failure model was used to determine the conventional limit pressure. The behavior of cohesive soil around the pressuremeter was studied by Jacques (2007). The influence of the permeability in a linear elastoplastic soil and of the geometry of the probe has been studied 
(Nahra and Frank (1986)) by the numerical expansion of a cylindrical cavity. The well-known theory of undrained behavior (Baguelin et al. (1972)) has been used (Prapaharan et al. (1989)) to investigate the pressuremeter expansion as a function of the undrained shear strength which varies with the strain rate. Numerical results with a constitutive model (Cambou and Bahar (1993)) show that the test can be assumed to be an undrained one with permeability lower than $10^{-10} \mathrm{~m} / \mathrm{s}$.

The stress strain behavior of the cohesive soil is assumed to follow either a linear elasticity relation (Gibson and Anderson (1961) and Silvestri (2003)) a hyperbolic elastoplastic relation (Silvestri (2004)) or a power law (Bolton and Whittle (1999)).

The theoretical analysis was chosen for its ability to describe the pressuremeter test from beginning to end with only a few parameters, when numerical analysis with sophisticated models needs many mechanical parameters, which cannot be precisely fitted. As a matter of fact, on a pressuremeter curve which is computed with an eight parameters model, only one or two parameters can be fitted, while six or seven other parameters must be assumed (Cambou and Bahar (1993)).

During the PMT, three different areas of soil were considered from the borehole wall to the infinite radius. Plasticity appears in the first zone between the radial stress $\left(\sigma_{r}\right)$ and the circumferential stress $\left(\sigma_{\theta}\right)$. This first plastic area extends between the radius $\mathrm{r}_{\mathrm{a}}$ (borehole wall) and $r_{b}$ (external radius of the first plastic area). The second plastic area between radii $r_{b}$ and $r_{c}$ (external radius of both plastic areas). An elastic area extends beyond radius $r_{c}$.

In the horizontal and vertical planes the equilibrium of an element of soil is given by

$$
\sigma_{r}-\sigma_{\theta}+\mathrm{r} \frac{d \sigma_{r}}{d r}=0
$$

The conventional limit pressure $\left(\mathrm{P}_{\mathrm{MM}}\right)$ was obtained by using the following expression. 
$\mathrm{P}_{\mathrm{lM}}=\gamma \mathrm{Z}+\mathrm{c}_{\mathrm{u}} \ln \left[\frac{2 G(\sqrt{2}-1)+c_{u}}{\left(1-K_{0}\right) \gamma z+c_{u}}\right]$

This relation is quite different from the Menard experimental correlation proposed by the European Regional Technical Committee (Amar et al. (1991)).

$\mathrm{P}_{\mathrm{IM}}=5.5 c_{u}+K_{0} \gamma \mathrm{z} \quad$ if $\mathrm{P}_{\mathrm{IM}}-K_{0} \gamma \mathrm{z}<300 \mathrm{Mpa}$

$\mathrm{P}_{\mathrm{IM}}=10\left(c_{u}-25\right)+K_{0} \gamma \mathrm{Z} \quad$ if $\mathrm{P}_{\mathrm{IM}}-K_{0} \gamma \mathrm{Z}>300 \mathrm{Mpa}$

The in-situ pressuremeter tests were carried out for over consolidated plastic clay in Paris. The theoretical pressuremeter curve and experimental one are drawn in one graph and compared. Then they used finite element program Plaxis (Brinkgreve and Vermeer (1998)) with the Tresca model to compute the value of the conventional limit pressure, which was compared to the result of theory. The model used was elastoplastic with a constant shearing modulus and five parameters (Young's modulus, Poisson's ratio, undrained shear strength, no friction and dilatancy angle). The method used for the validation was a variation of only one parameter when the other ones stay constant. Finally influence of the vertical stress, coefficient of pressure at rest $\left(\mathrm{K}_{0}\right)$, shearing modulus and shear strength in the conventional limit pressure was discussed.

\subsubsection{ANALYTICAL METHOD}

Analytical method was used to evaluate soil parameters which were used in the M-C model by Fawaz et al. (2014). Different rheological laws have been developed to describe the behavior of soils around the pressuremeter. The study of Combarieu (1995) based on Pasturel's formula has evolved a theoretical relation between the limit pressure $\left(\mathrm{P}_{\mathrm{L}}\right)$ and soil parameters $\mathrm{E}, \mathrm{v}, \mathrm{c}$ and $\varphi$. In case of cohesive and granular soils ( $\mathrm{c}$ and $\varphi$ different to 0 ) that relation is given below.

$$
\mathrm{P}_{\mathrm{L}}+\mathrm{c} \cot \varphi=\left(\mathrm{P}_{0}+\operatorname{ccot} \varphi\right)(1+\sin \varphi)\left(\frac{E}{2(1+v)\left(P_{0}+\operatorname{ccot} \varphi\right)(\sin \varphi)}\right)^{\frac{\sin \varphi}{1+\sin \varphi}}
$$


This formula was used to calculate the cohesion and the friction angle by using the value of the pressure at rest $\left(\mathrm{P}_{0}\right)$ and limit pressure $\left(\mathrm{P}_{\mathrm{L}}\right)$ determined from the in-situ test and elastic modulus obtained in the numerical analysis.

\subsection{SUMMARY}

This chapter discussed about the literature review of the statistical correlation between SPT and PMT and numerical simulation of the PMT. In the case of statistical correlation, most of the correlation work done in the past was for sand and clay and only one for tills. There is almost no correlation work on Toronto glacial tills. So far there is no clear explanation on correlation between these two parameters for glacial till especially Toronto glacial tills. The literature has a significant lack of information concerning any glacial till such as cohesive or cohesionless glacial tills.

In the case of numerical simulation of PMT, there is bulk of information available but no one has simulated the model for real soil profile. Every author mentions the geometry of the model with some dimensions but they don't clearly mention the soil layers above and below the test depth. In addition to soil profile, authors did not properly define the geometry size, width of the model from axis of symmetry and depth below the mid-point of the probe. Further literature survey show that commonly used models are HSM and MCM. Each author's used different boundary conditions, geometry size, probe L/D ratio and type of model which are shown in Table 2.7.

Table 2.7 Reviews of the literature survey regards FEM simulation of PMT

\begin{tabular}{|c|c|c|c|c|}
\hline Author's name & $\begin{array}{l}\text { Type of } \\
\text { model }\end{array}$ & $\begin{array}{l}\text { Probe } \\
\text { L/D } \\
\text { ratio }\end{array}$ & Model geometry size & Boundary condition \\
\hline $\begin{array}{l}\text { Plaxis 2D } \\
\text { manual (2012) }\end{array}$ & $\mathrm{HSM}^{*}$ & 2.7 & $\begin{array}{l}\text { Diameter } 1.2 \mathrm{~m} \\
\text { Height } 0.75 \mathrm{~m}\end{array}$ & $\begin{array}{l}\text { Bottom }-\mathrm{VF}^{*} \\
\text { Vertical both side- } \mathrm{HF}^{\sqrt{ }}\end{array}$ \\
\hline $\begin{array}{l}\text { Fawaz et } \\
\text { al.(2014) }\end{array}$ & $\mathrm{MCM}^{\bullet}$ & $\begin{array}{c}\text { Not } \\
\text { mention }\end{array}$ & $\begin{array}{l}\text { Width } 7 \mathrm{~m} \\
\text { Height } 7 \mathrm{~m} \text { below the } \\
\text { probe }\end{array}$ & $\begin{array}{l}\text { Bottom - Both fixity } \\
\text { Vertical both side- } \mathrm{HF}^{\sqrt{ }}\end{array}$ \\
\hline
\end{tabular}




\begin{tabular}{|c|c|c|c|c|}
\hline Jacques (2007) & $\begin{array}{l}\text { Tresca } \\
\text { Model }\end{array}$ & 7.5 & $\begin{array}{l}\text { Diameter } 5 \mathrm{~m} \\
\text { Height } 2 \mathrm{~m} \text { above the } \\
\text { mid of probe }\end{array}$ & $\begin{array}{l}\text { Bottom - VF* } \\
\text { Right side vertical - both direction } \\
\text { free } \\
\text { Left side vertical - } \mathrm{HF}^{\sqrt{ }}\end{array}$ \\
\hline $\begin{array}{l}\text { Levasseur et } \\
\text { al. (2009) }\end{array}$ & $\mathrm{MCM}^{\circ}$ & $\begin{array}{c}\text { Not } \\
\text { mention }\end{array}$ & $\begin{array}{l}\text { Diameter } 1.20 \mathrm{~m} \\
\text { Height } 1.5 \mathrm{~m}\end{array}$ & $\begin{array}{l}\text { Bottom - Both fixity } \\
\text { Vertical both side- } \mathrm{HF}^{\vee}\end{array}$ \\
\hline $\begin{array}{l}\text { Schanz et al. } \\
\text { (2000) }\end{array}$ & $\mathrm{MCM}^{\circ}$ & 2.9 & $\begin{array}{l}\text { Diameter } 1.2 \mathrm{~m} \\
\text { Height } 1.5 \mathrm{~m}\end{array}$ & $\begin{array}{l}\text { Bottom - VF } \\
\text { Vertical both side- } \mathrm{HF}^{V}\end{array}$ \\
\hline $\begin{array}{l}\text { Malecot et al. } \\
\text { (2009) }\end{array}$ & $\mathrm{MCM}^{\bullet}$ & 8 & $\begin{array}{l}\text { Diameter } 6 \mathrm{~m} \\
\text { Height } 5 \mathrm{~m}\end{array}$ & $\begin{array}{l}\text { Bottom - Both fixity } \\
\text { Right side vertical- } \mathrm{HF}^{\sqrt{ }} \\
\text { Left side vertical- } \mathrm{HF}^{\vee} \text { below probe }\end{array}$ \\
\hline Rita (2008) & $\mathrm{HSM}^{*}$ & 6.7 & Not define & Not define \\
\hline $\begin{array}{l}\text { Sedran et al. } \\
\text { (2013) }\end{array}$ & HSM* $^{*}$ & 6.5 & Not define & Not define \\
\hline Monnet (2012) & $\mathrm{MCM}^{\circ}$ & 6 & $\begin{array}{l}\text { Diameter } 10 \mathrm{~m} \\
\text { Height } 2 \mathrm{~m} \text { above the } \\
\text { mid of probe }\end{array}$ & $\begin{array}{l}\text { Bottom }-\mathrm{VF}^{*} \\
\text { Right side vertical }- \text { Free } \\
\text { Left side vertical }-\mathrm{HF}^{\vee} \text { above } \\
\text { probe }\end{array}$ \\
\hline $\begin{array}{l}\text { Michel et } \\
\text { al.(2000) }\end{array}$ & $\mathrm{HSM}^{*}$ & $\begin{array}{c}\text { Not } \\
\text { define }\end{array}$ & Not define & Not define \\
\hline $\begin{array}{l}\text { Waschkowski } \\
\text { (1976) }\end{array}$ & & 6.6 & & \\
\hline
\end{tabular}

* HSM - Hardening soil model

- MCM - Mohr Coulomb model

$* \mathrm{VF}-$ Vertical fixity of the model

$\sqrt{ } \mathrm{HF}-$ Horizontal fixity of the model 


\section{CHAPTER 3: STATISTICAL CORRELATION BETWEEN SPT-N VALUES WITH PMT PARAMETERS FOR GLACIAL TILLS}

\subsection{INTRODUCTION}

The statistical analysis is carried out in this chapter to investigate the relationship between SPT$\mathrm{N}$ value with both $\mathrm{E}_{\mathrm{PMT}}$ and $\mathrm{P}_{\mathrm{L}}$. The first step is to collect the pairs of PMT test data and SPT-N value at the same depths in the same boreholes. Secondly selected data are corrected and filtered according to the methodology discussed in the section 3.2. Thirdly the general ranges of SPT-N, $E_{P M T}$ and $P_{L}$ values are discussed in the section 3.3. Then correlation between SPT-N value with both $\mathrm{E}_{\mathrm{PMT}}$ and $\mathrm{P}_{\mathrm{L}}$ are discussed in the section 3.4 and 3.5 respectively. In addition the comparisons are done between the studied correlation equations with literature equations and values in the section 3.6. And finally the ranges of corrected and filtered SPT-N, $\mathrm{E}_{\mathrm{PMT}}$ and $\mathrm{P}_{\mathrm{L}}$ values and correlation equations are summarized in the section 3.7.

\subsection{DATA SELECTION, SPT-N VALUE CORRECTION AND FILTERING}

SPTs conducted near the PMTs at similar depths are selected to develop the relationship between SPT-N values and both $\mathrm{E}_{\mathrm{PMT}}$ and $\mathrm{P}_{\mathrm{L}}$ in this chapter for the following stations such as Allen, Avenue, Bathurst, Bayview, Bermondsey, Blackcreek, Birchmount, Caledonia, Don Mills, Kennedy, Lesile, Mount Dennis, Victoria, Warden, West Portal and Wynford. The typical borehole report is attached in Appendix 3.1. The pairs of readings (SPT-N and EPMT) for clayey silt and silty sand till are not available from these stations in this study.

\section{SPT-N correction}

The first correction for SPT-N values are performed according to Cao et al. (2015) for field measured SPT-N for penetration depth. This means that some situations, the field SPT hammer are refused while driving, when it reached boulders or cobbles. In this situation hammering is stopped and number of blows is counted before full penetration of $305 \mathrm{~mm}$. Then the field SPT- 
$\mathrm{N}$ values are corrected according to equation 2.1 in Chapter 2. For example, when the sample tube is driven $175 \mathrm{~mm}$ into the ground and the number of blows is 40 , then the SPT N-value is $70\left(=\frac{305 \times 40}{175}\right)$. Typical correction calculation sheet is attached in Appendix 3.2.

The second corrections are performed according to the CFEM (2006). Because of the variability in equipment and operating conditions, direct use of SPT-N values for geotechnical design is not recommended. As a result, many corrections shall be done on the field SPT-N values. Those corrections are described in Chapter 2, section 2.2.1.2 based on CFEM (2006). In case of cohesive glacial tills, overburden correction is not accommodated in this study. In these situations, the SPT-N became SPT- $(N)_{60}$. In the case of cohesionless glacial tills, overburden corrections is accommodated. In these situations, the SPT-N became SPT- $\left(N_{1}\right)_{60}$.Typical correction calculation sheets for each station is attached in Appendix 3.2. Based on these corrections, the conclusion is made that after the correction, the SPT-N value became half of the field measured SPT-N value, specifically in the deeper elevation.

\section{Filtering data}

The processing of these data is one of the most challenging works in this project. Reliability of an analysis result is mostly defined by the accuracy of selected data rather than the method used for the analysis. Therefore, the selection of the most representative parameters for a site is the key to a successful analysis. With that in mind, in order to evaluate the correlation between SPT$\mathrm{N}$ values and both $\mathrm{E}_{\mathrm{PMT}}$ and $\mathrm{P}_{\mathrm{L}}$ more accurately, the compiled data are filtered by using the following methodology.

(1) The SPT's often reached refusal, i.e. blow count $(\mathrm{N})$ values are greater than 100 for $300 \mathrm{~mm}$ or less increment when the SPT sampler hits a cobble or boulder within the glacial till. As a result the SPT-N values are assigned values of 100 or more than 100 . The SPT-N values greater than 100 are disregarded.

(2) The data situated far from the trend line is discarded by visual inspection compare to other data. 
(3) In such cases the same SPT-N value is associated with different values of both $\mathrm{E}_{\mathrm{PMT}}$ and $\mathrm{P}_{\mathrm{L}}$ and this pair of readings are omitted.

Apparently more theoretical study is needed to develop a sound rationale to filter the data.

\subsection{GENERAL RANGES OF SPT-N, EMT $_{\text {AND }}$ P $_{\text {L }}$ FOR GLACIAL TILLS}

The ranges of SPT-N, $\mathrm{E}_{\mathrm{PMT}}$ and $\mathrm{P}_{\mathrm{L}}$ values are determined for both groups in which all of the data are collected from in-situ tests and in which the data are corrected and filtered.

\subsubsection{RANGES OF SPT-N VALUES}

The ranges of SPT-N values of cohesive and cohesionless glacial tills are shown in Figure 3.1 and Figure 3.2 respectively. Further ranges, means and standard deviations of SPT-N values for different types of soil and all soil, for all data as well as corrected and filtered data are shown in Table 3.1. The data that were discarded during the filtering process are shown in Figure 3.1, with small circles in the all data analysis. The percentages (\%) marked in Figure 3.2 represents most of the range values that belong to the thick portion of the range diagrams. 
Table 3.1 Summary of SPT-N values for different types of soil

\begin{tabular}{|c|c|c|c|c|}
\hline \multirow{2}{*}{ Soil type } & \multicolumn{5}{|c|}{ Ranges of SPT-N values for all data (Corrected \& Filtered data) } \\
\cline { 2 - 5 } & No. of data & Range & Mean & $\begin{array}{c}\text { Standard } \\
\text { deviation }\end{array}$ \\
\hline \multicolumn{5}{|c|}{ Cohesive glacial tills } \\
\hline Silty clay & $38(22)$ & $8-91(6-62)$ & $38(26)$ & $23(16)$ \\
\hline Silty clay till & $25(14)$ & $5-98(3-31)$ & $32(15)$ & $24(9)$ \\
\hline Clayey silt till & $21(16)$ & $6-152(4-67)$ & $46(29)$ & $32(19)$ \\
\hline All soil & $84(52)$ & $5-152(3-67)$ & $38(24)$ & $26(16)$ \\
\hline & & Cohesionless glacial tills & $29(23)$ \\
\hline Sand & $23(18)$ & $21-150(13-97)$ & $61(50)$ & $33(30)$ \\
\hline Silt & $16(14)$ & $8-123(4-98)$ & $66(46)$ & $23(23)$ \\
\hline Sandy silt & $22(20)$ & $6-86(4-91)$ & $53(45)$ & $21(18)$ \\
\hline Silty sand & $23(18)$ & $38-127(25-76)$ & $63(49)$ & $20(25)$ \\
\hline Sandy silt till & $8(7)$ & $34-93(16-80)$ & $58(60)$ & $60(49)$ \\
\hline All soil & $92(77)$ & $6-150(4-98)$ & & $26(23)$ \\
\hline
\end{tabular}




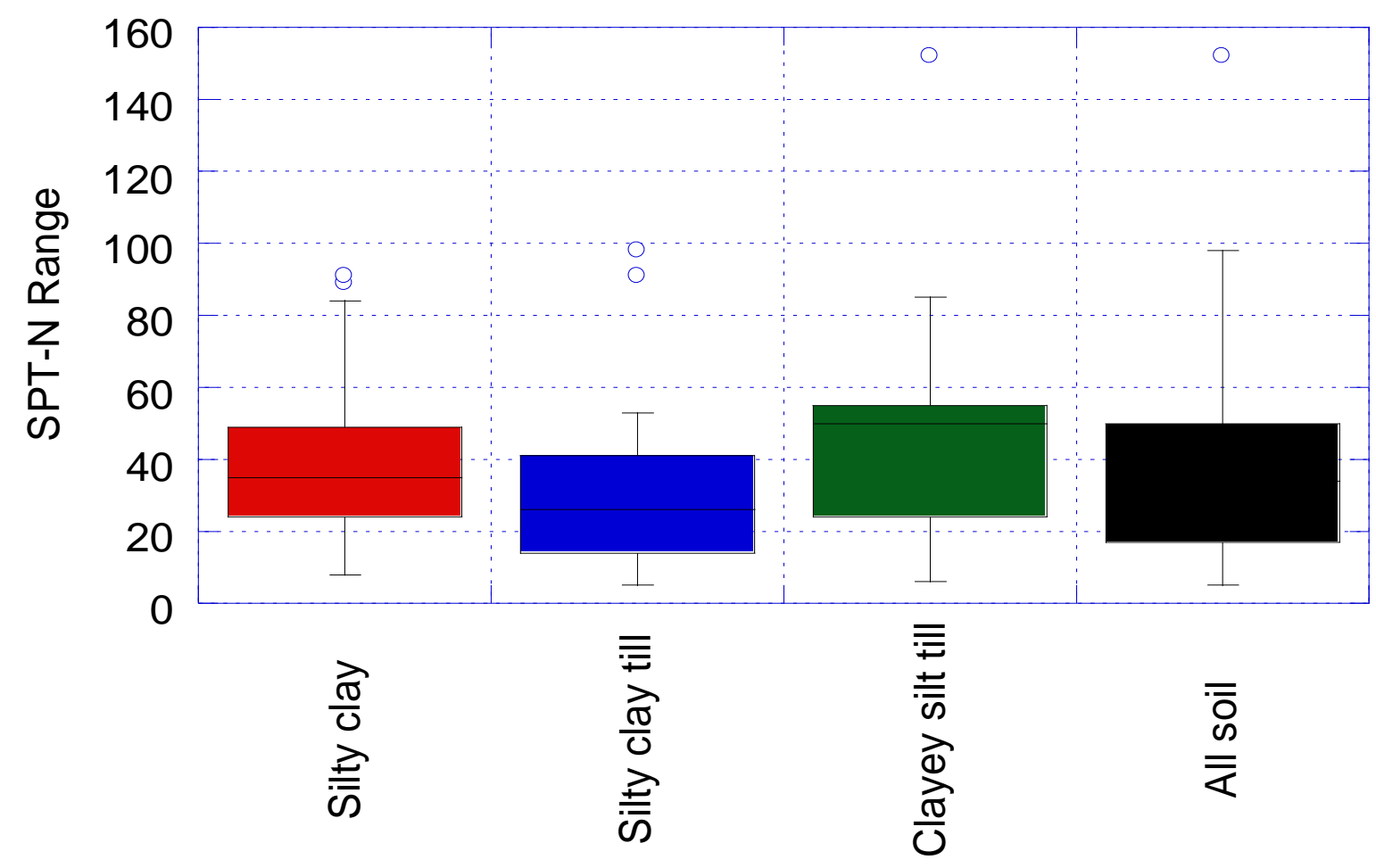

All data

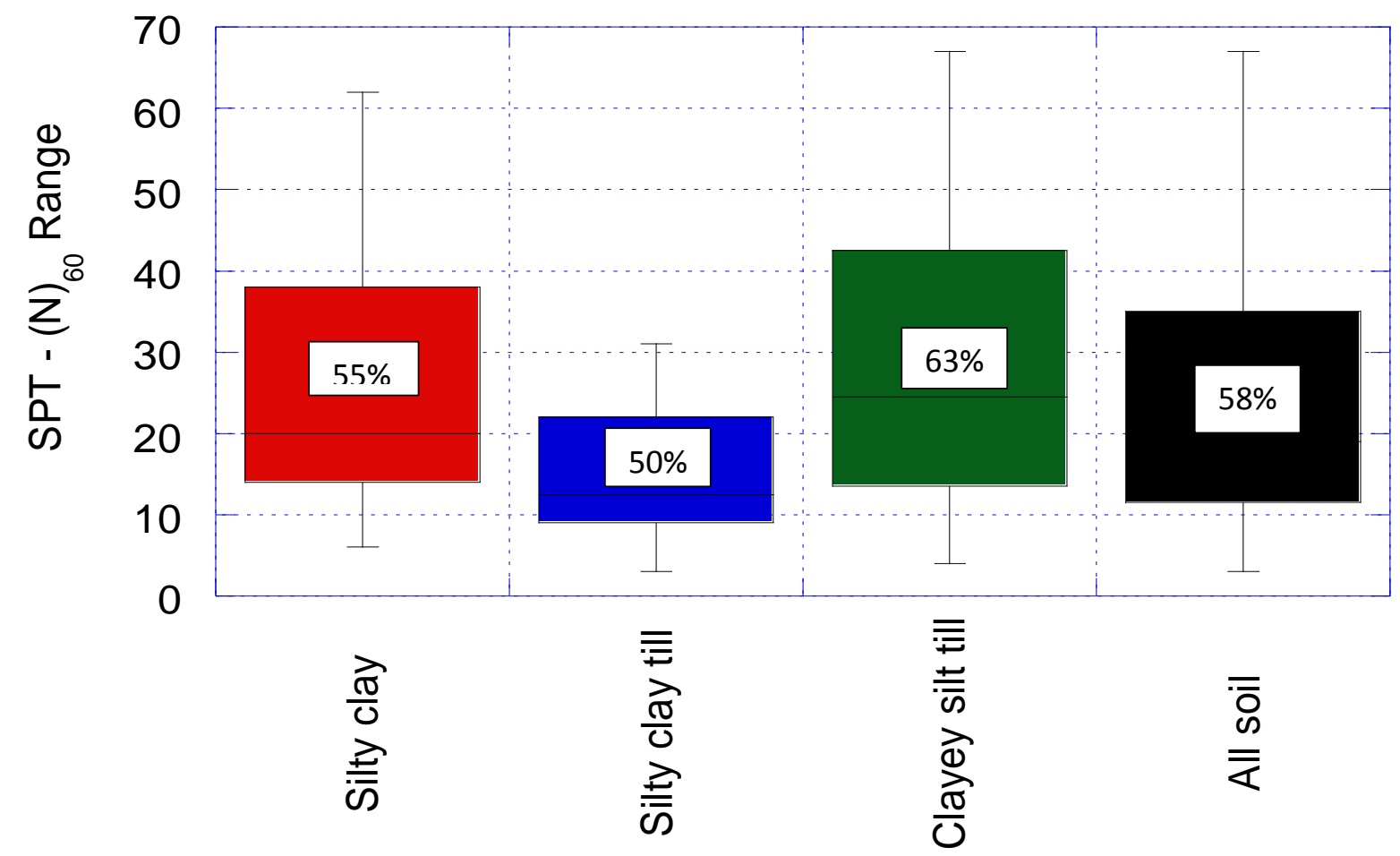

Corrected and filtered data

Figure 3.1 Ranges of SPT-N values for cohesive glacial tills 


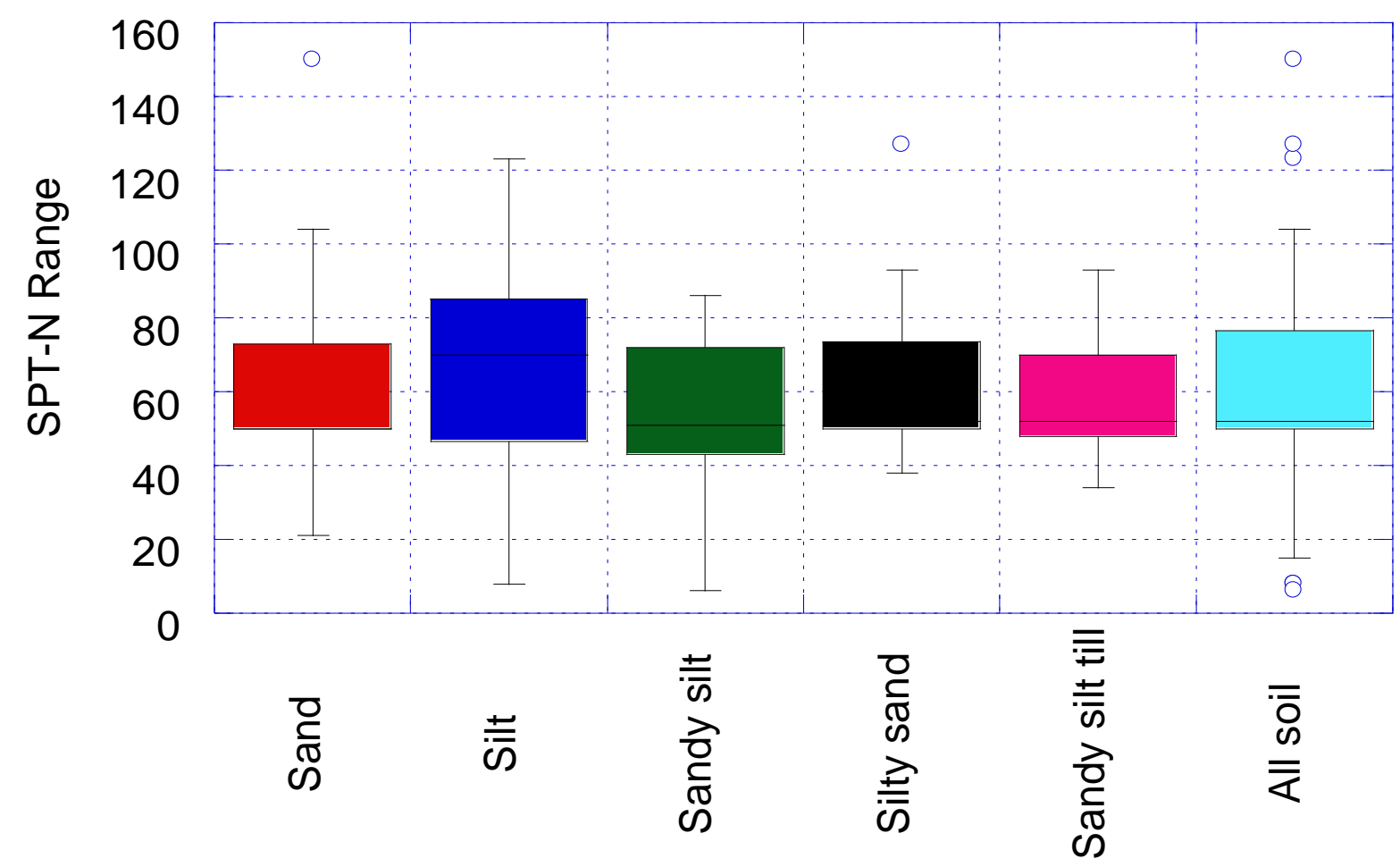

All data

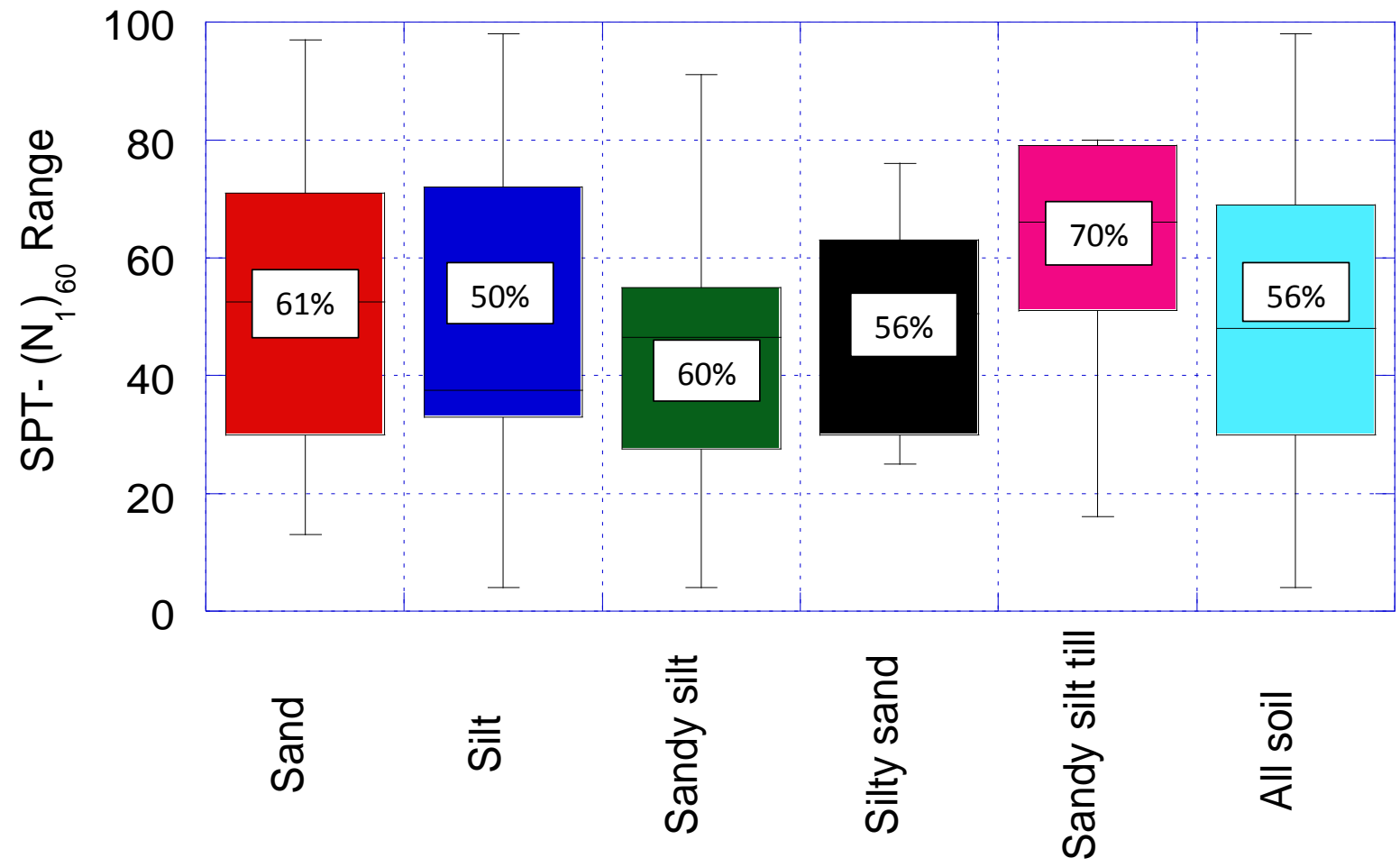

Corrected and filtered data

Figure 3.2 Ranges of SPT-N values for cohesionless glacial tills 


\subsubsection{RANGES OF E EMT VALUES}

The ranges of $\mathrm{E}_{\mathrm{PMT}}$ values of cohesive and cohesionless glacial tills are shown in Figure 3.3 and Figure 3.4 respectively. Further ranges, means and standard deviations of $\mathrm{E}_{\mathrm{PMT}}$ values for different types of soil and all soil, for all data as well as filtered data are shown in Table 3.2. The data that were discarded during the filtering process are shown in Figure 3.3, with small circles in the all data analysis. The percentages (\%) marked in Figure 3.4 represents most of the range values that belong to the thick portion of the range diagrams.

Table 3.2 Summary of EPMT values for different types of soil

\begin{tabular}{|c|c|c|c|c|}
\hline \multirow{2}{*}{ Soil type } & \multicolumn{3}{|c|}{ Ranges of $\mathrm{E}_{\mathrm{PMT}}$ values (MPa) for all data (Filtered data) } \\
\cline { 2 - 5 } & No. of data & Range & Mean & $\begin{array}{c}\text { Standard } \\
\text { deviation }\end{array}$ \\
\hline \multicolumn{5}{|c|}{ Cohesive glacial tills } \\
\hline Silty clay & $38(23)$ & $11-224(11-150)$ & $76(65)$ & $47(39)$ \\
\hline Silty clay till & $25(13)$ & $4-223(4-36)$ & $49(18)$ & $51(10)$ \\
\hline Clayey silt till & $21(16)$ & $16-288(16-131)$ & $82(58)$ & $76(41)$ \\
\hline All soil & $84(52)$ & $4-288(4-150)$ & $69(51)$ & $58(40)$ \\
\hline \multicolumn{5}{|c|}{ Cohesionless glacial tills } \\
\hline Sand & $22(14)$ & $26-197(26-149)$ & $104(91)$ & $48(46)$ \\
\hline Silt & $16(14)$ & $19-140(19-140)$ & $84(82)$ & $32(33)$ \\
\hline Sandy silt & $22(15)$ & $2-163(28-78)$ & $71(53)$ & $47(17)$ \\
\hline Silty sand & $23(13)$ & $10-231(39-96)$ & $105(69)$ & $58(18)$ \\
\hline Sandy silt till & $8(6)$ & $18-273(18-134)$ & $112(76)$ & $79(39)$ \\
\hline All soil & $91(62)$ & $2-273(18-149)$ & $93(74)$ & $53(34)$ \\
\hline
\end{tabular}




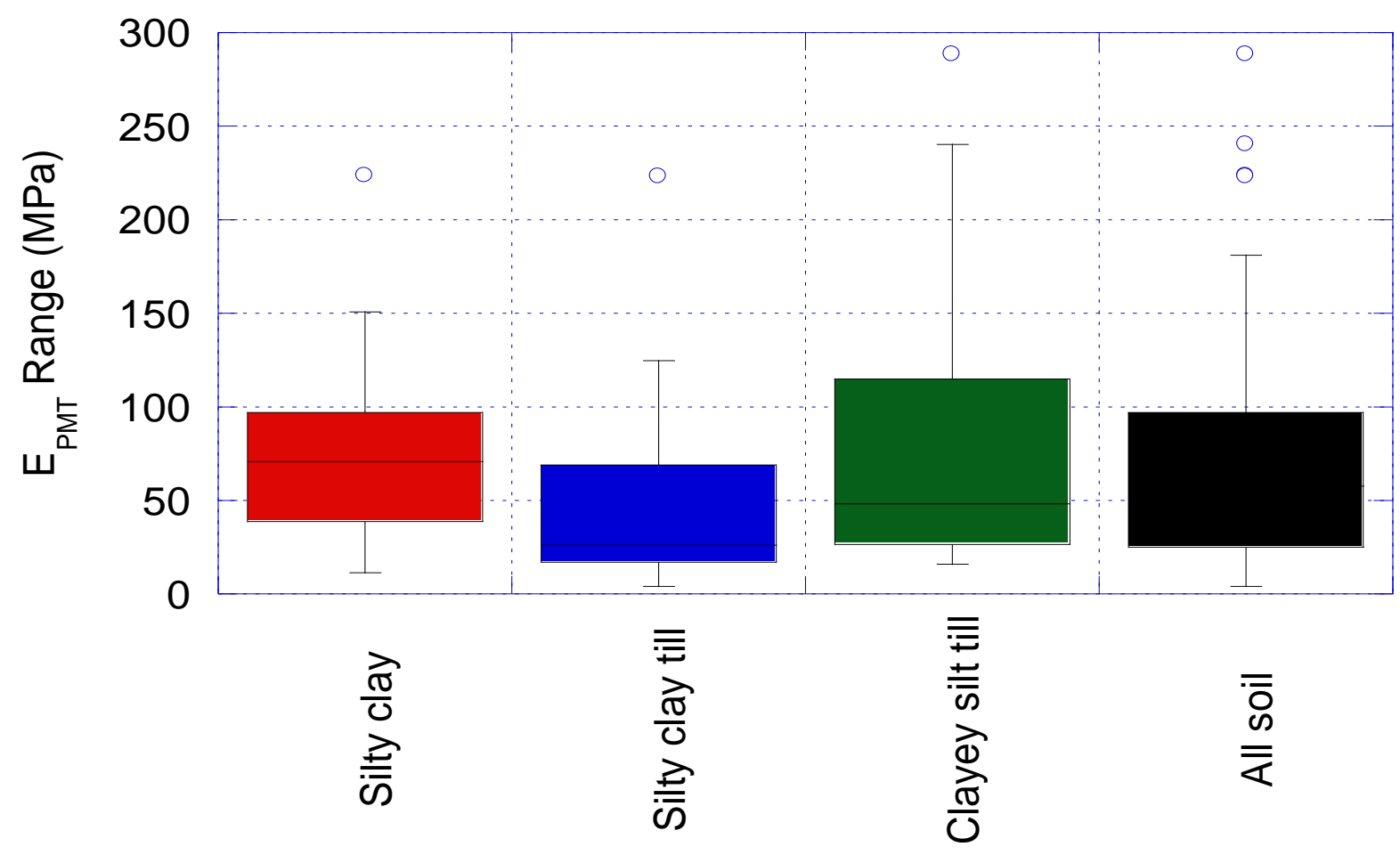

All data

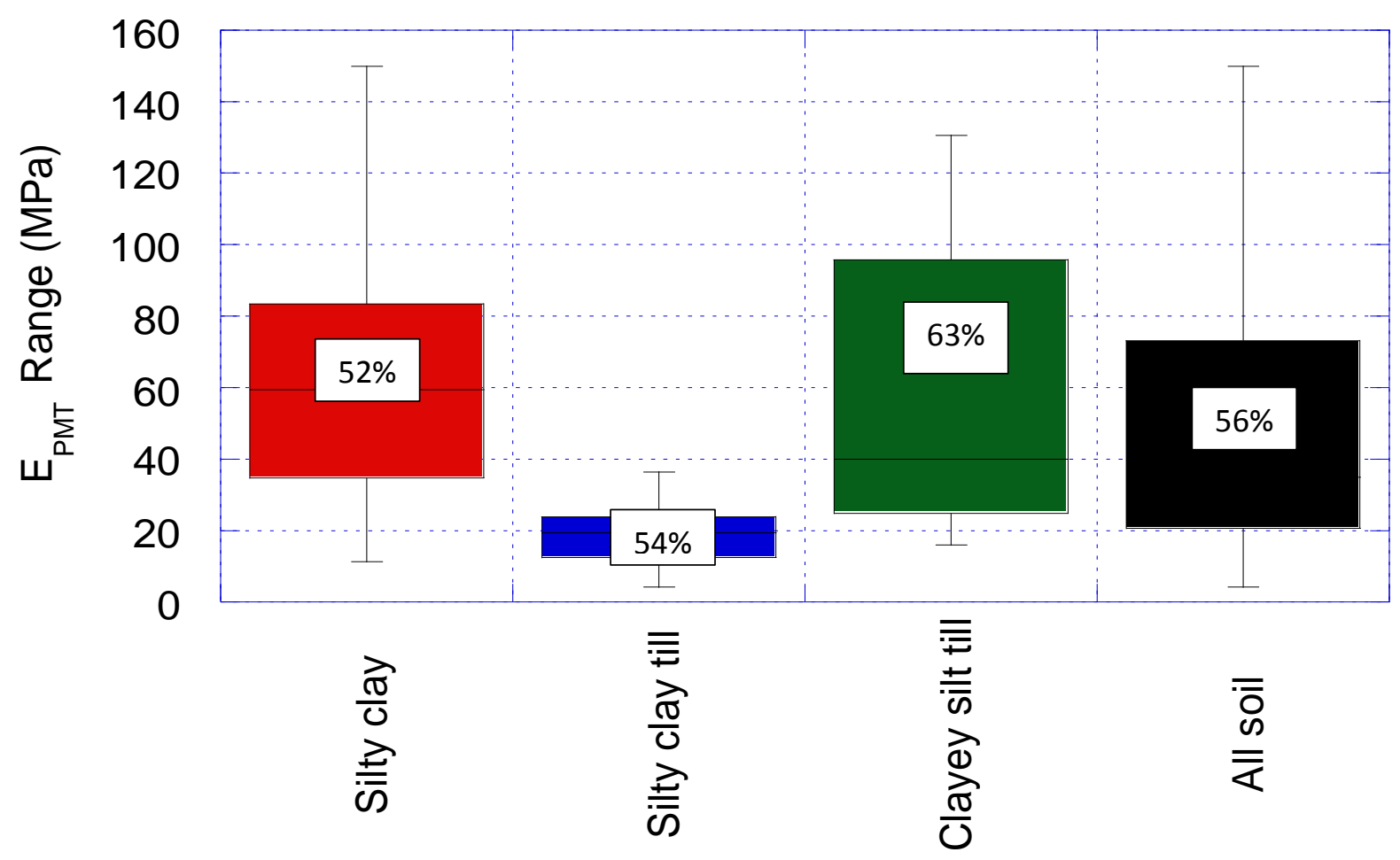

Filtered data

Figure 3.3 Ranges of E 


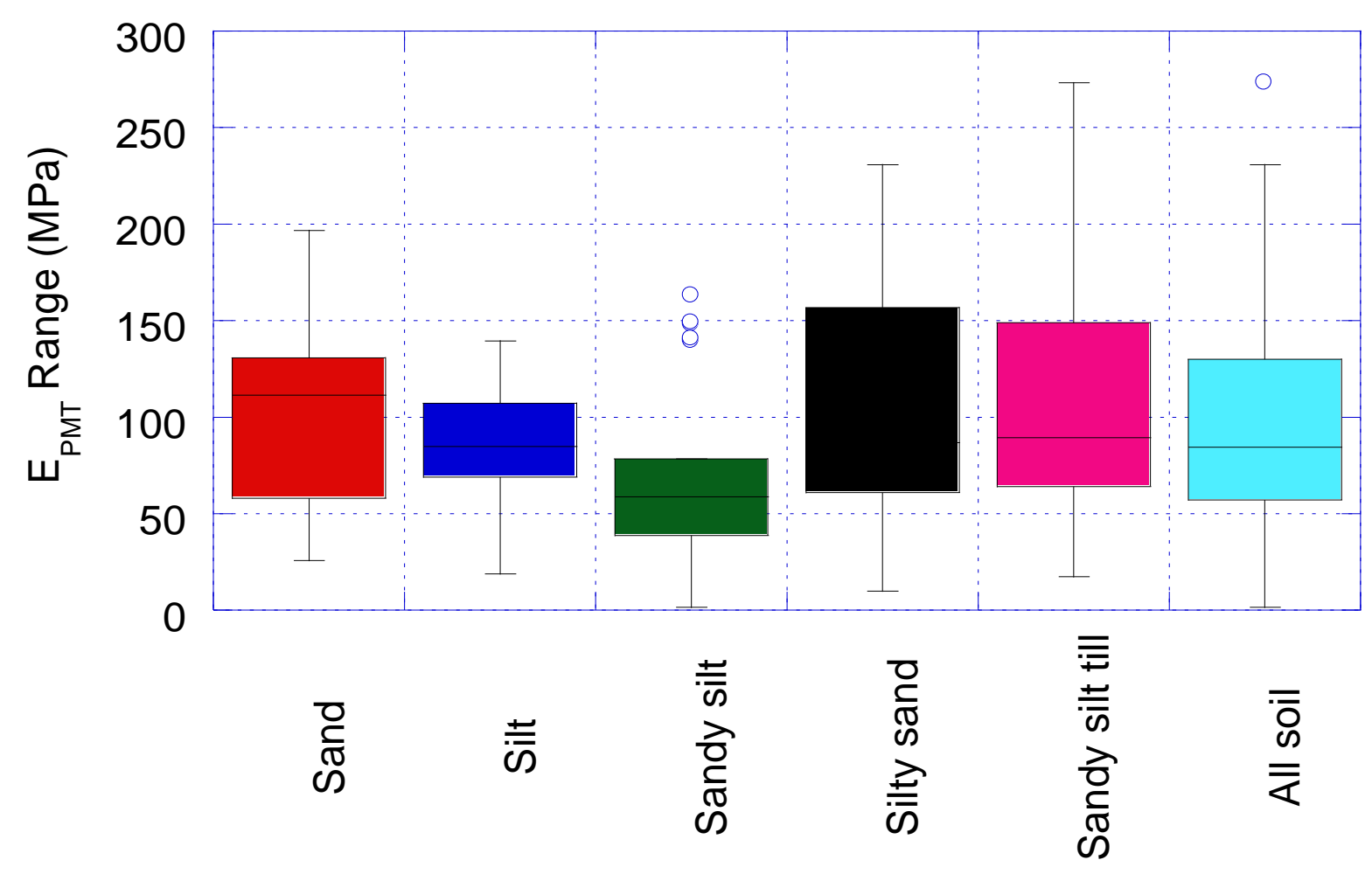

All data

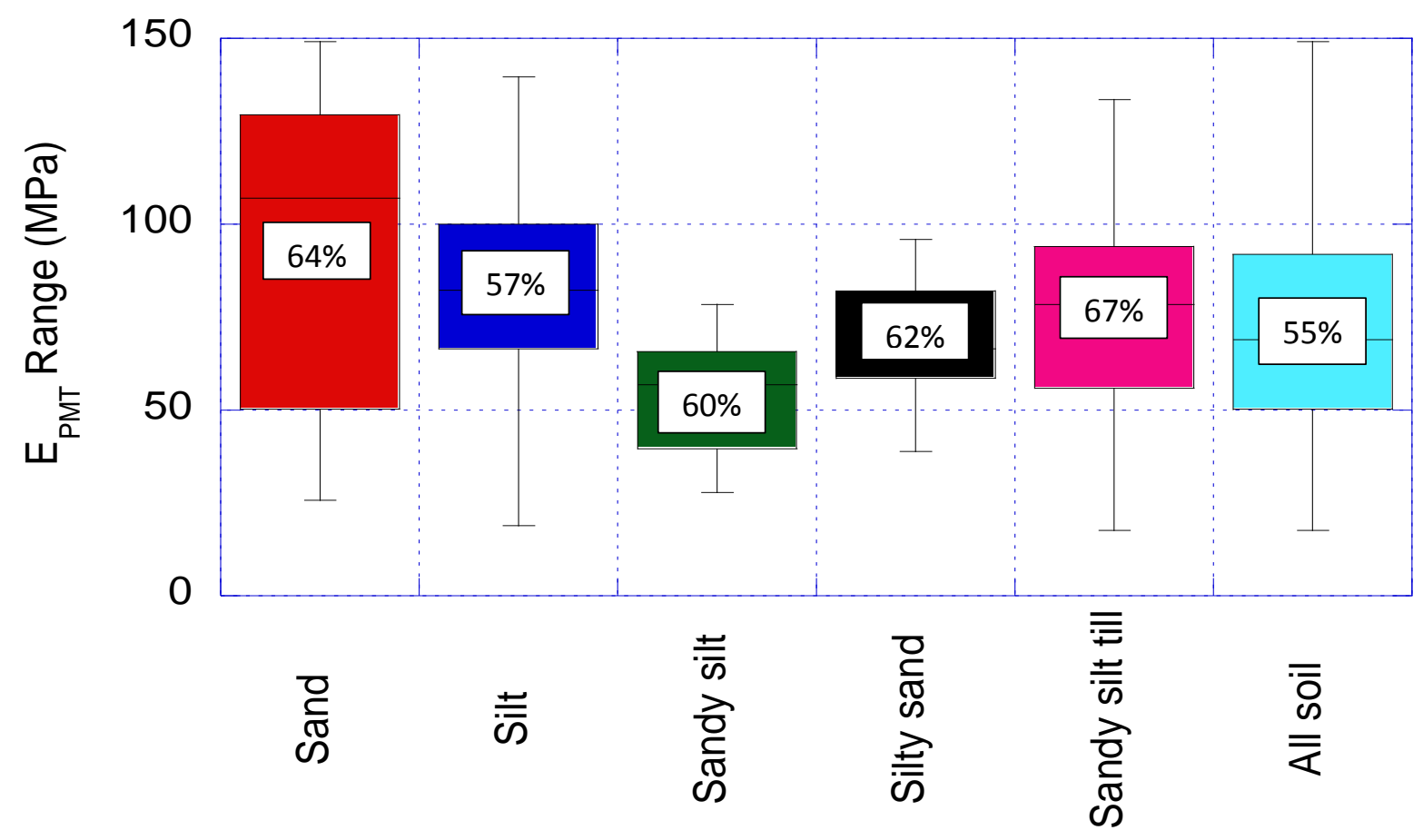

Filtered data

Figure 3.4 Ranges of $\mathrm{E}_{\mathrm{PMT}}$ values for cohesionless glacial tills 


\subsubsection{RANGES OF $P_{L}$ VALUES}

The ranges of $\mathrm{P}_{\mathrm{L}}$ values of cohesive and cohesionless glacial tills are shown in Figure 3.5 and Figure 3.6 respectively. Further ranges, means and standard deviations of $\mathrm{P}_{\mathrm{L}}$ values for different types of soil and all soil, for all data as well as filtered data are shown in Table 3.3. The data that were discarded during the filtering process are shown in Figure3.3, with small circles in the all data analysis. The percentages (\%) marked in Figure 3.4 represents most of the range values that belong to the thick portion of the range diagrams.

Table 3.3 Summary of $\mathrm{P}_{\mathrm{L}}$ values for different types of soil

\begin{tabular}{|c|c|c|c|c|}
\hline \multirow{2}{*}{ Soil type } & \multicolumn{5}{|c|}{ Ranges of $P_{\mathrm{L}}$ values (MPa) for all data (Filtered data) } \\
\cline { 2 - 5 } & No. of data & \multicolumn{5}{|c|}{ Range } & Mean & $\begin{array}{c}\text { Standard } \\
\text { deviation }\end{array}$ \\
\hline \multicolumn{5}{|c|}{ Cohesive glacial tills } \\
\hline Silty clay & $38(22)$ & $0.64-9.02(1.25-5.56)$ & $3.56(3.62)$ & $1.89(1.23)$ \\
\hline Silty clay till & $25(17)$ & $0.41-7.78(0.41-5.63)$ & $2.72(2.35)$ & $2.13(1.85)$ \\
\hline Clayey silt till & $20(15)$ & $1.0-14.15(1.00-6.00)$ & $4.0(2.79)$ & $3.55(1.72)$ \\
\hline All soil & $83(54)$ & $0.41-14.15(0.41-6.00)$ & $3.42(3.00)$ & $2.47(1.65)$ \\
\hline \multicolumn{5}{|c|}{ Cohesionless glacial tills } \\
\hline Sand & $23(17)$ & $0.21-13.32(2.42-13.32)$ & $7.23(7.97)$ & $3.55(3.46)$ \\
\hline Silt & $16(12)$ & $0.97-14.57(3.17-9.08)$ & $7.10(7.05)$ & $3.04(1.81)$ \\
\hline Sandy silt & $22(18)$ & $0.29-15.79(1.33-9.03)$ & $5.40(4.52)$ & $3.65(2.13)$ \\
\hline Silty sand & $23(18)$ & $1.42-14.30(1.42-13.55)$ & $7.28(6.37)$ & $3.80(3.67)$ \\
\hline Sandy silt till & $8(4)$ & $1.7-22.49(6.00-8.04)$ & $9.64(7.02)$ & $6.83(0.87)$ \\
\hline All soil & $92(69)$ & $0.21-22.49(1.33-13.55)$ & $7.00(6.44)$ & $4.00(3.09)$ \\
\hline
\end{tabular}




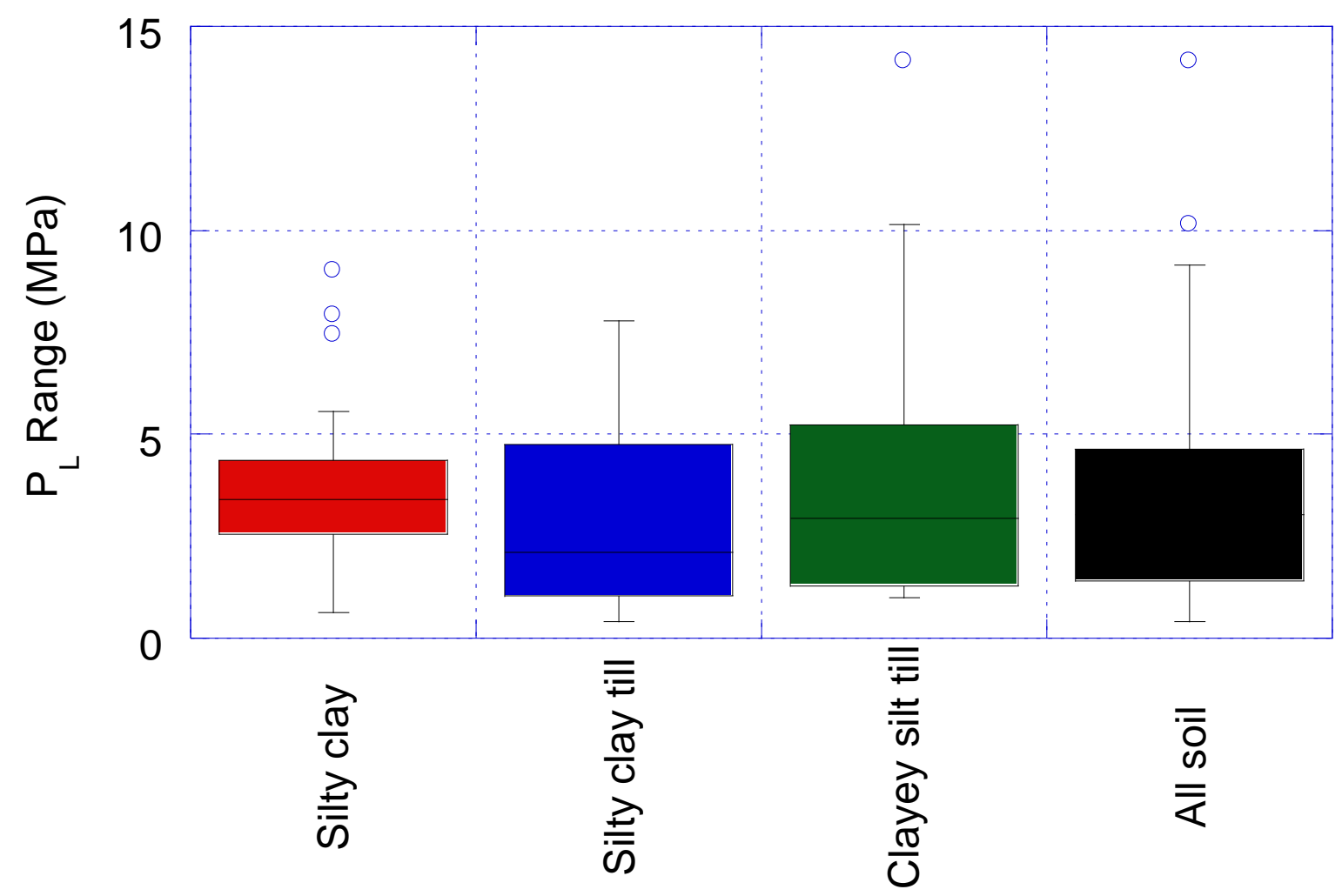

All data

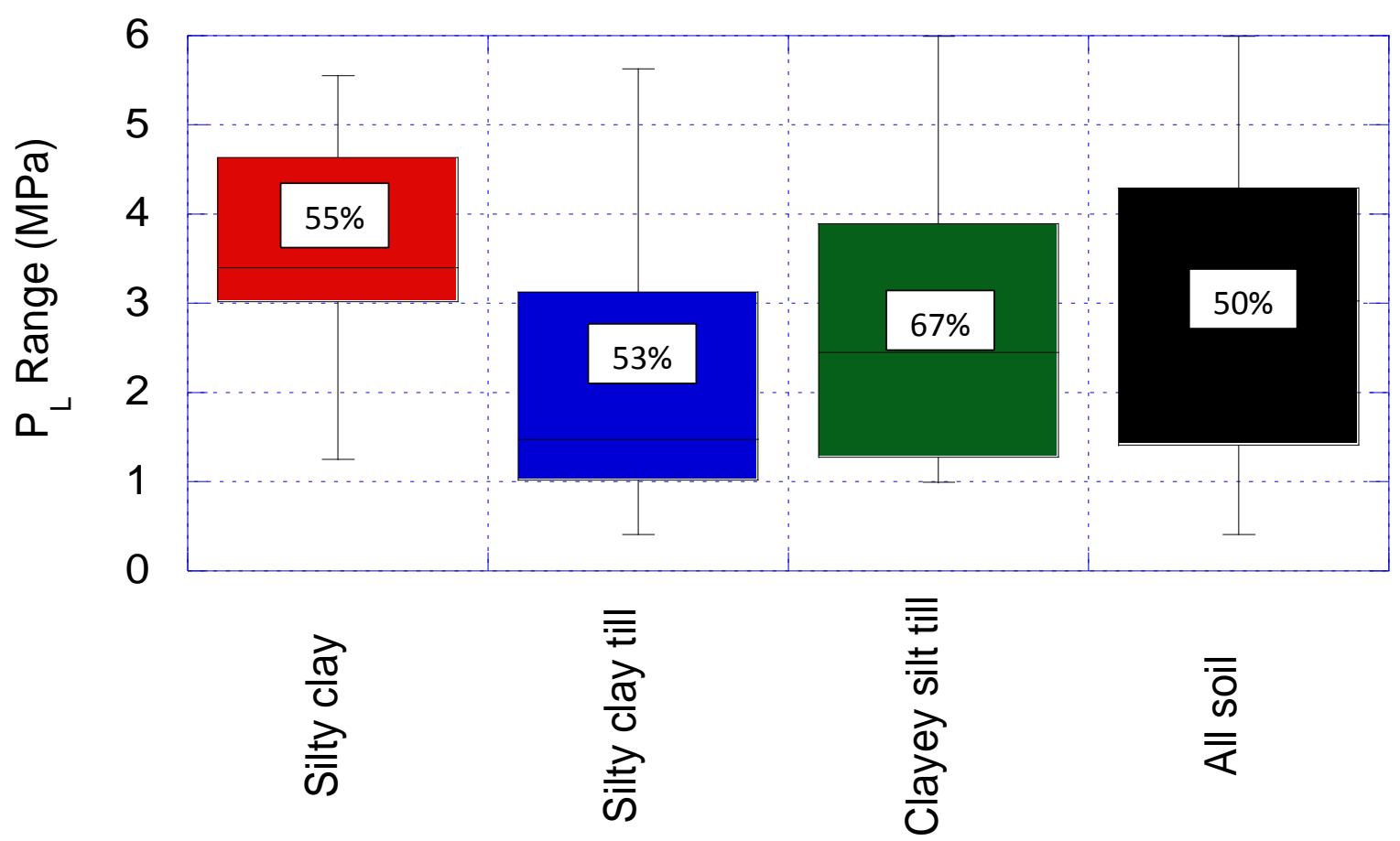

Filtered data

Figure 3.5. Ranges of $P_{L}$ values for cohesive glacial tills 


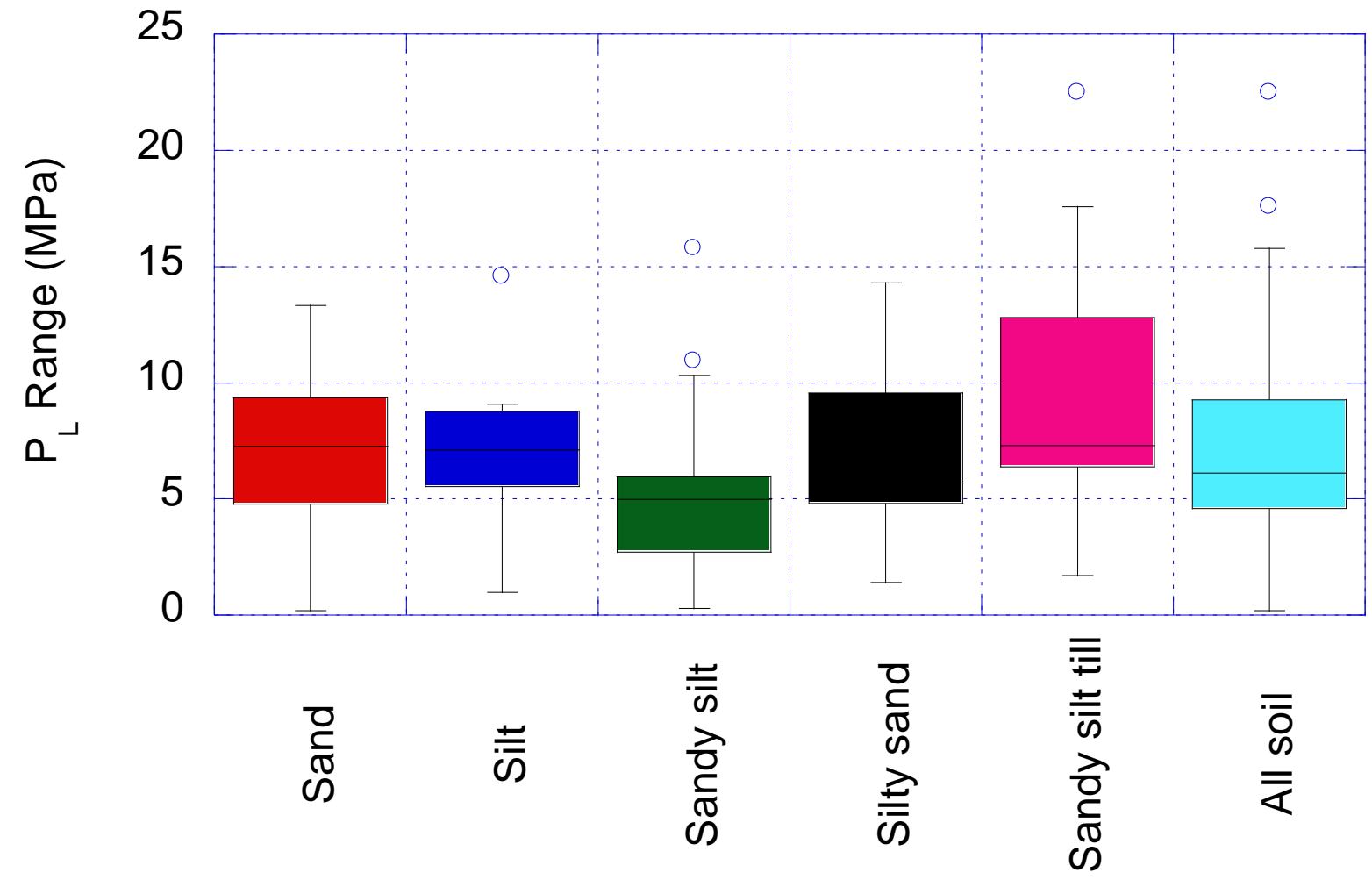

All data

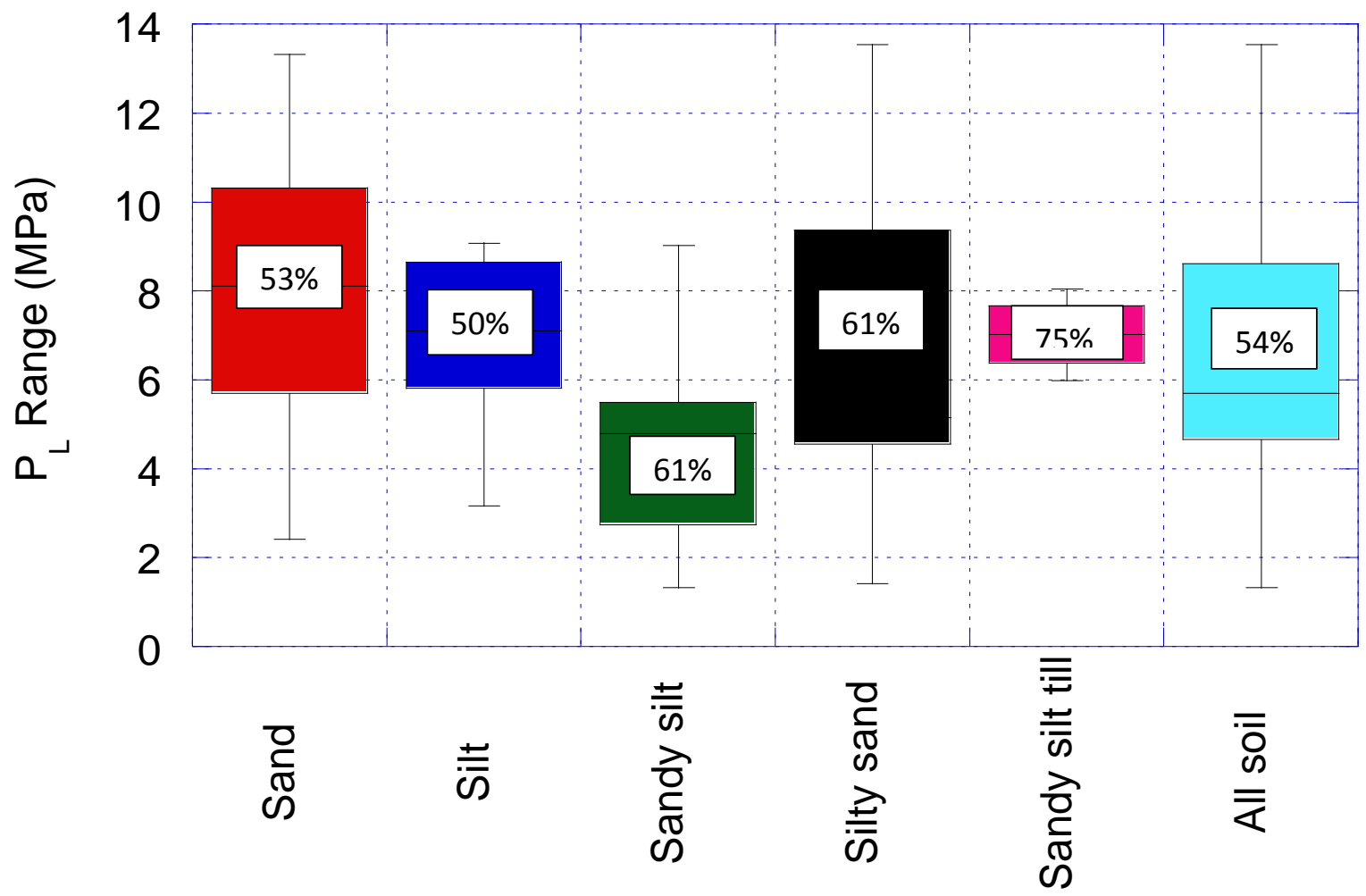

Filtered data

Figure 3.6 Ranges of $\mathrm{P}_{\mathrm{L}}$ values for cohesionless glacial tills 


\subsection{CORRELATION BETWEEN SPT-N AND E EMT VALUES}

(a) Low plasticity cohesive glacial tills

The correlation between SPT-N values and $\mathrm{E}_{\mathrm{PMT}}$ have been plotted for low plasticity cohesive glacial tills in both original data as well as corrected and filtered data formats, as shown in Figure 3.7. The correlation functions are determined for both cases in which all the data were included and in which the data were corrected and filtered. The correlation functions and coefficients are given in Table 3.4. The corrected and filtered data analysis provides a much improved correlation coefficient compared to all original data analysis. 


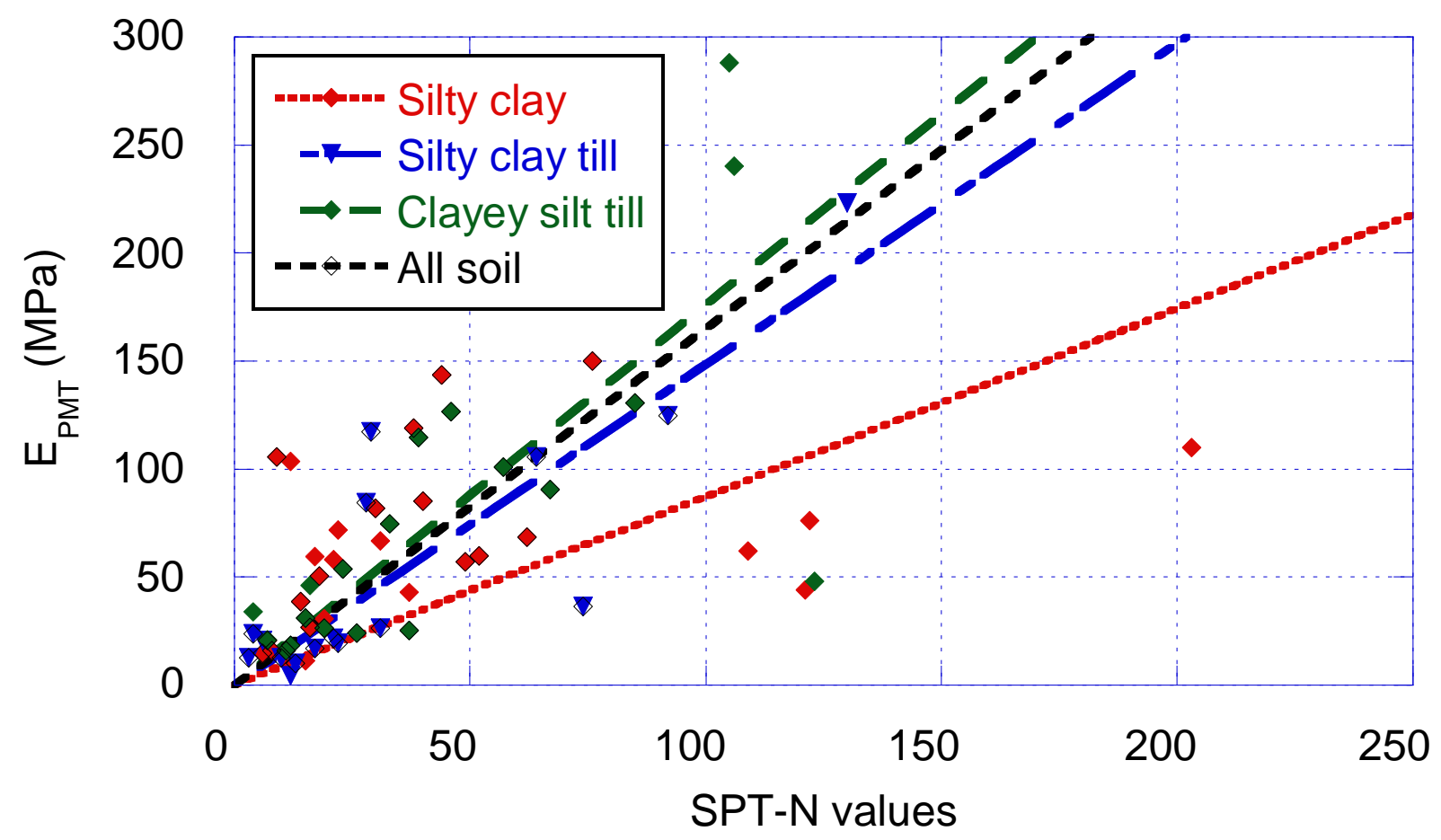

All data

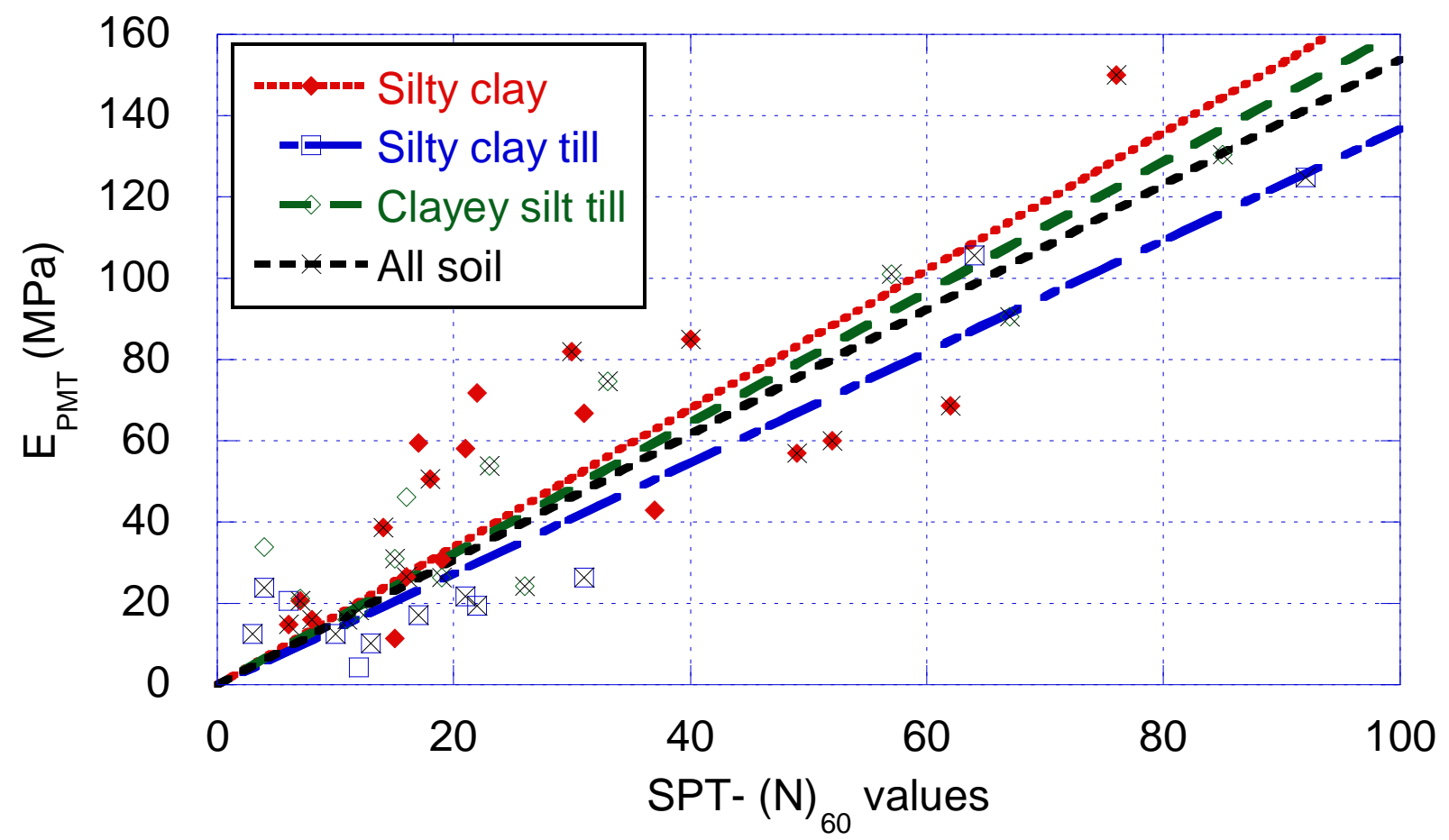

Corrected and filtered data

Figure 3.7 Correlations between SPT-N vs E 
(b) Cohesionless glacial tills

The correlation between SPT-N values and $\mathrm{E}_{\mathrm{PMT}}$ have been plotted for cohesionless glacial tills in both original data as well as corrected and filtered data formats, as shown in Figure 3.8. The correlation functions and coefficients are given in Table 3.4. The corrected and filtered soil data analysis shows that there is a better correlation relationship between SPT-N and EPMT. After corrected and filtered, the sandy silt till does not have enough pairs of data. 


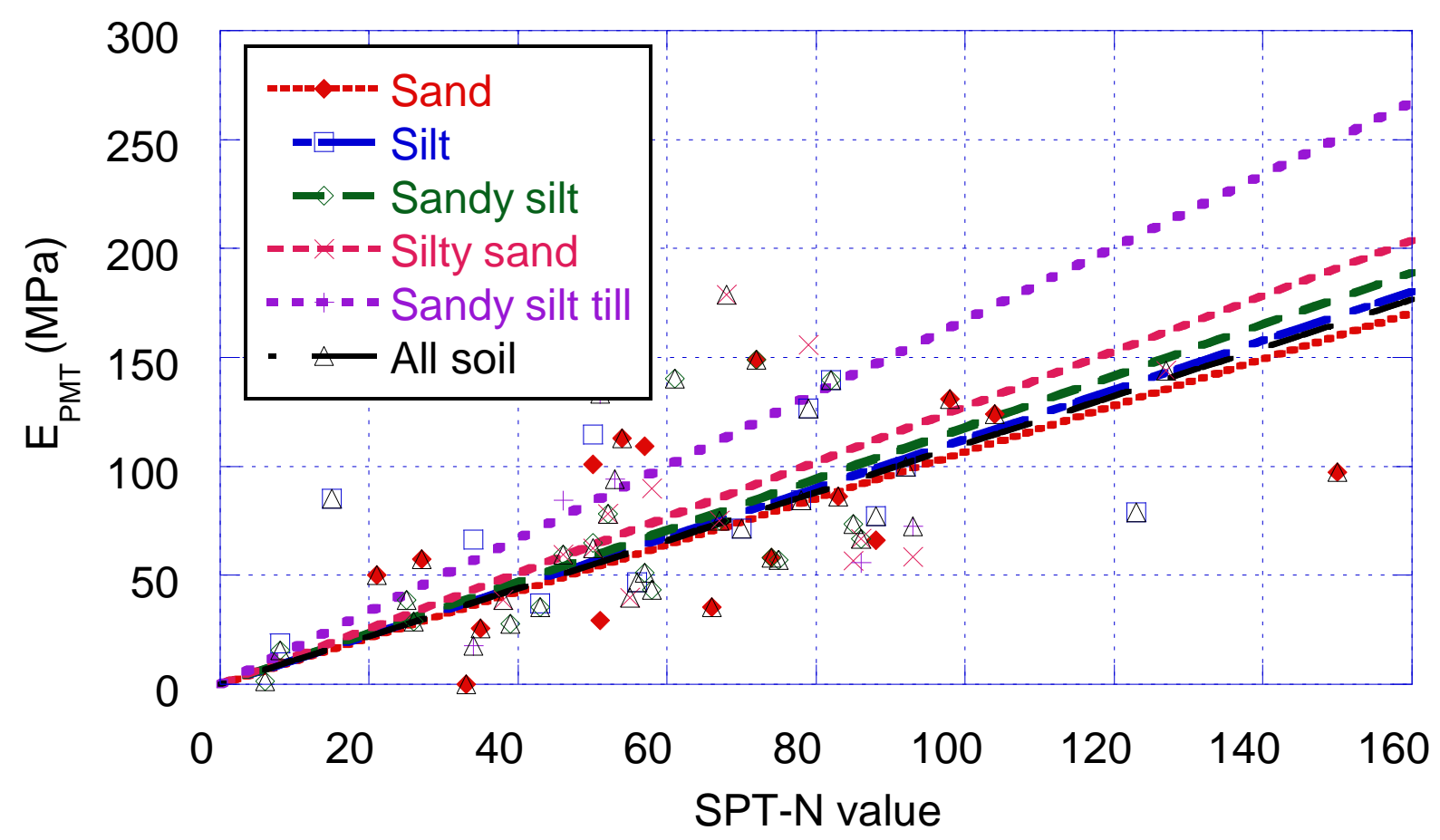

All data

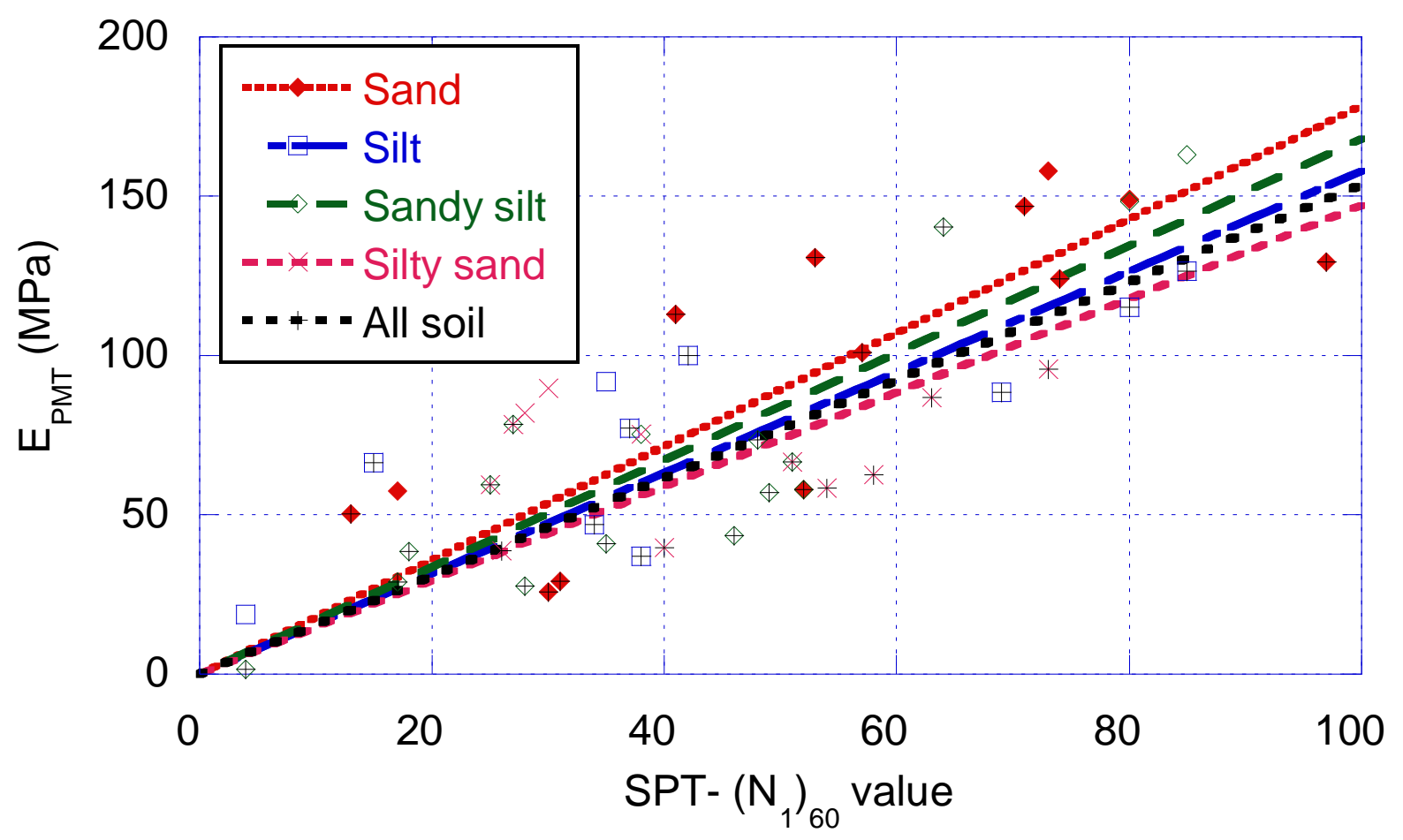

Corrected and filtered data

Figure 3.8 Correlations between SPT-N vs EPMT $_{\text {for cohesionless glacial tills }}$ 


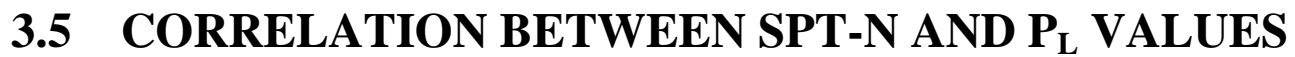

(a) Low plasticity cohesive glacial tills

The correlation between SPT-N values and $\mathrm{P}_{\mathrm{L}}$ have been plotted for low plasticity cohesive glacial tills in both original data as well as corrected and filtered data formats, as shown in Figure 3.9. The correlation functions are determined for both cases in which all the data were included and in which the data were corrected and filtered. The correlation functions and correlation coefficients are given in Table 3.4. The corrected and filtered data analysis provides a much improved correlation coefficient compared to all original data analysis. 


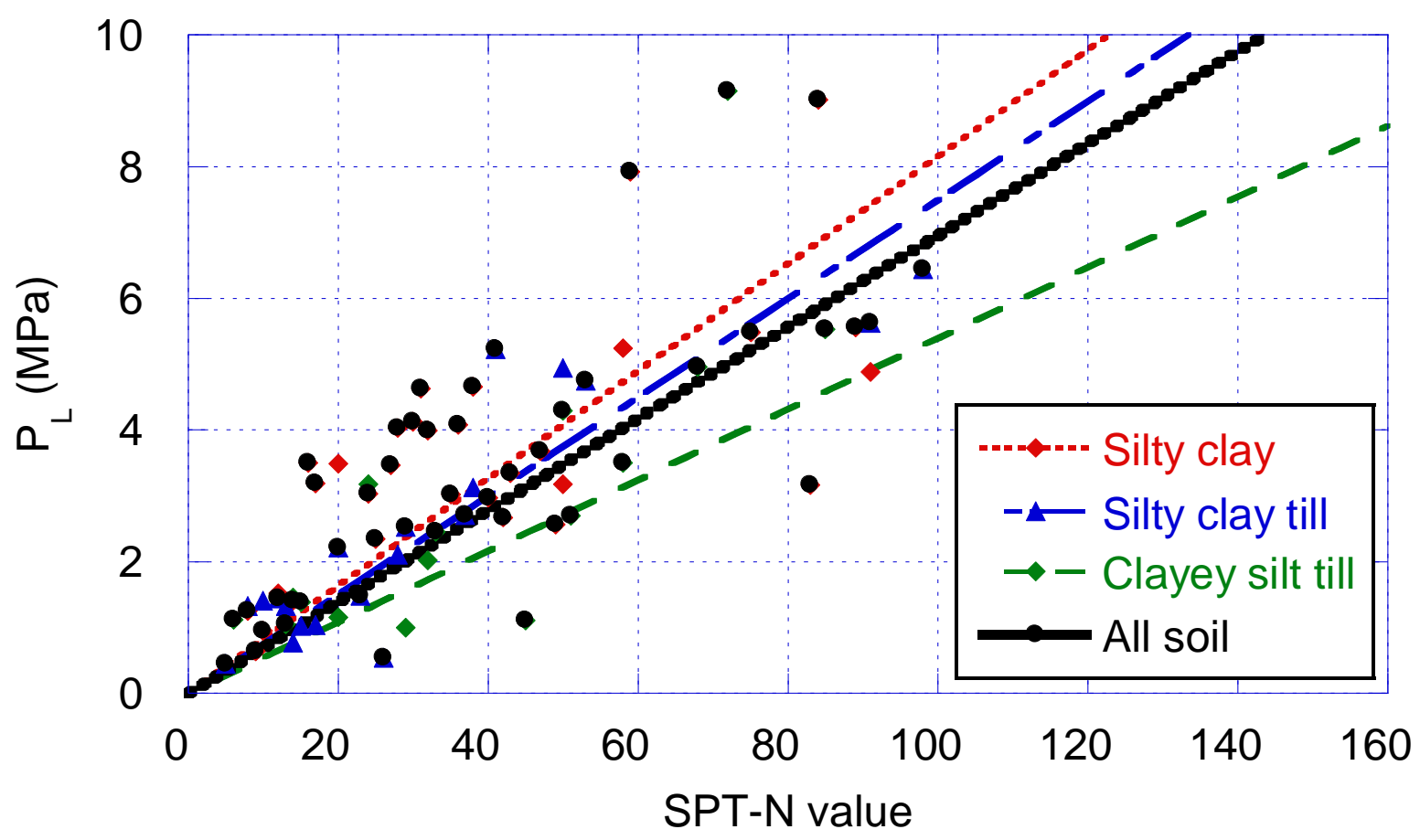

All data

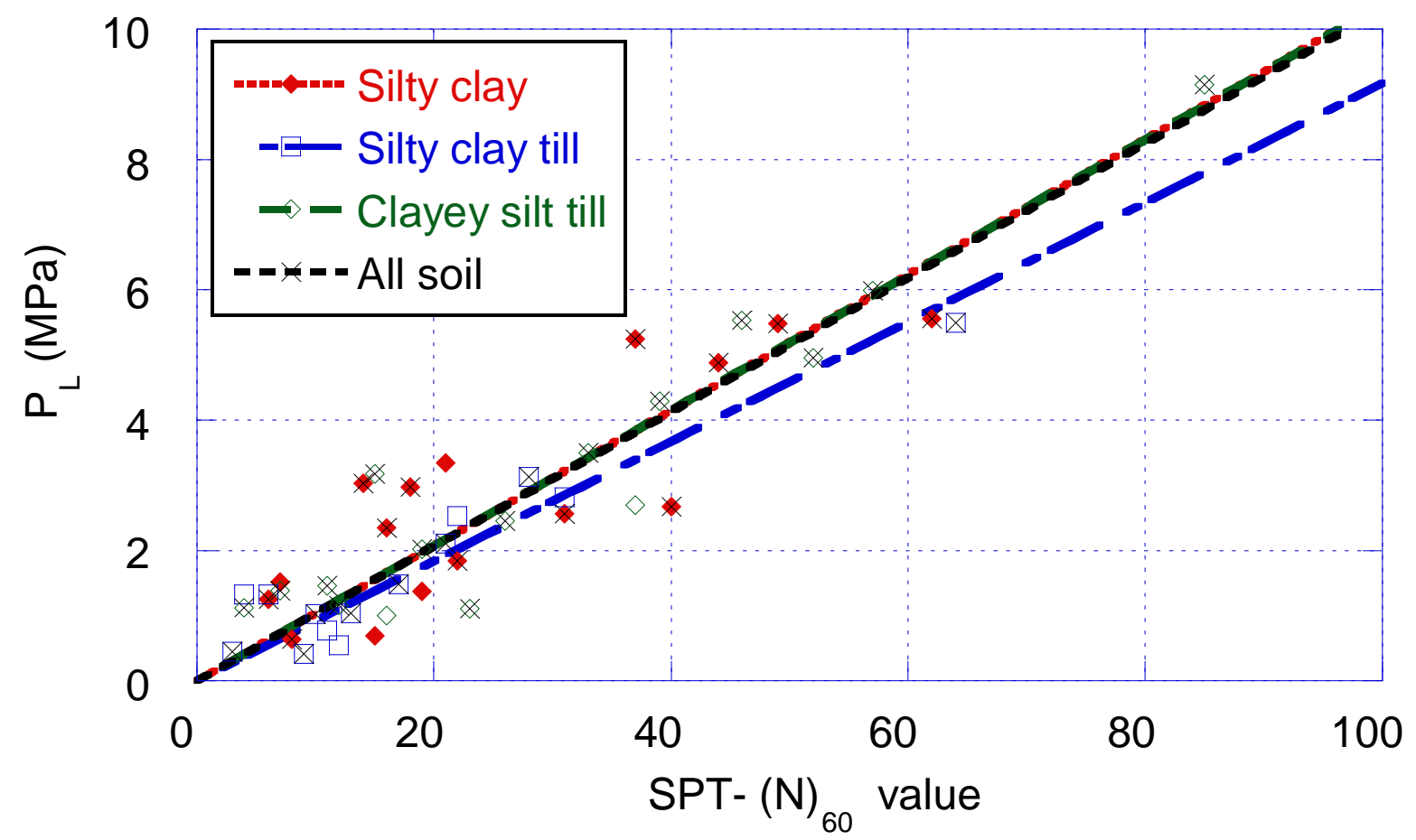

Corrected and filtered data

Figure 3.9 Correlations between SPT-N vs $\mathrm{P}_{\mathrm{L}}$ for cohesive glacial tills 
(b) Cohesionless glacial tills

The correlation between SPT-N values and $\mathrm{P}_{\mathrm{L}}$ have been plotted for cohesionless glacial tills in both original data as well as corrected and filtered data formats, as shown in Figure 3.10. The correlation functions and coefficients are given in Table 3.4. The all soil data analysis shows that there is a weak correlation relationship between SPT-N and $\mathrm{P}_{\mathrm{L}}$ where the correlation coefficient $\left(\mathrm{R}^{2}\right)$ is 0.04 to 0.46 . After corrected and filtered, sandy silt till does not have enough pairs of data. The corrected and filtered data analysis provides a much improved correlation coefficient (0.67 to 0.85 ) compared to all the original data analysis. 


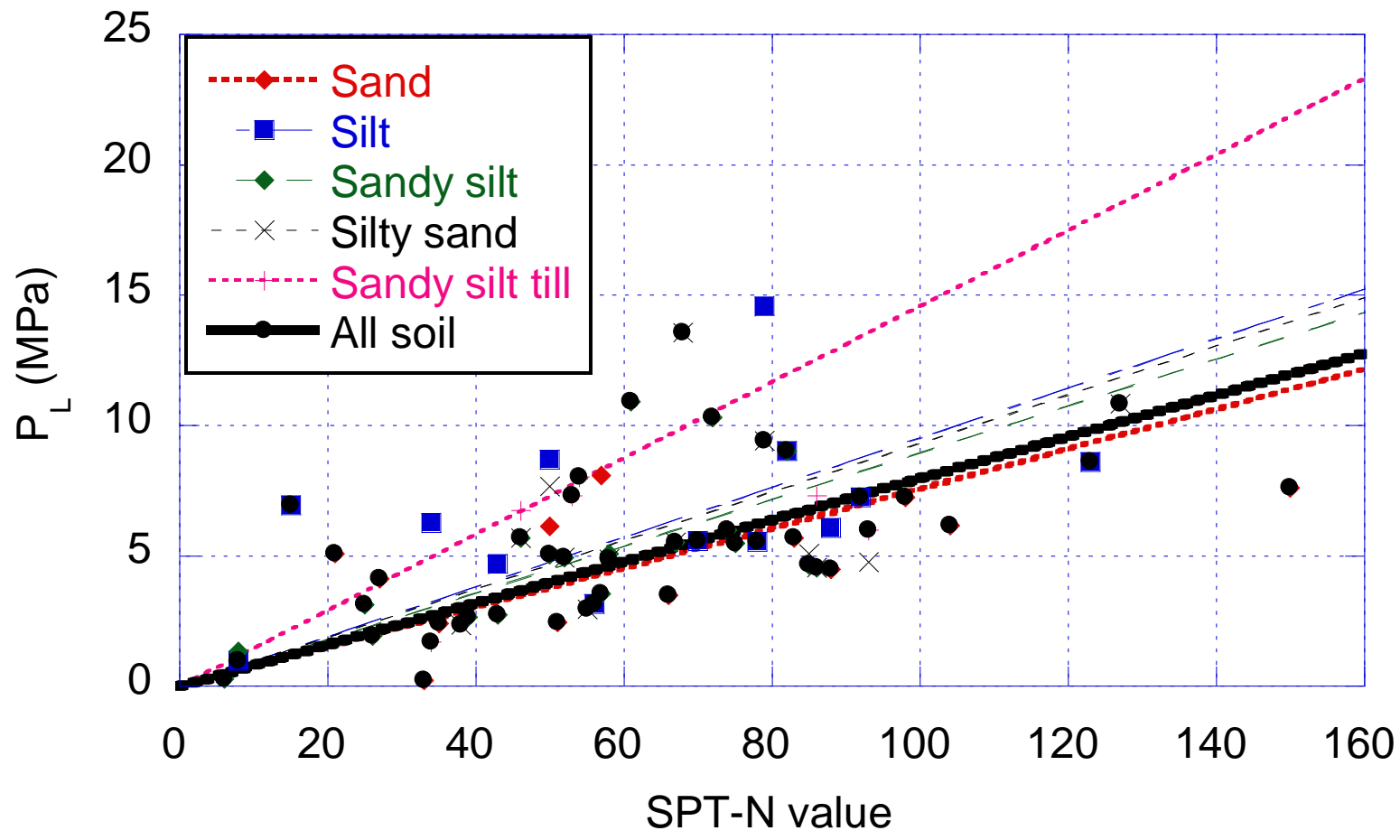

All data

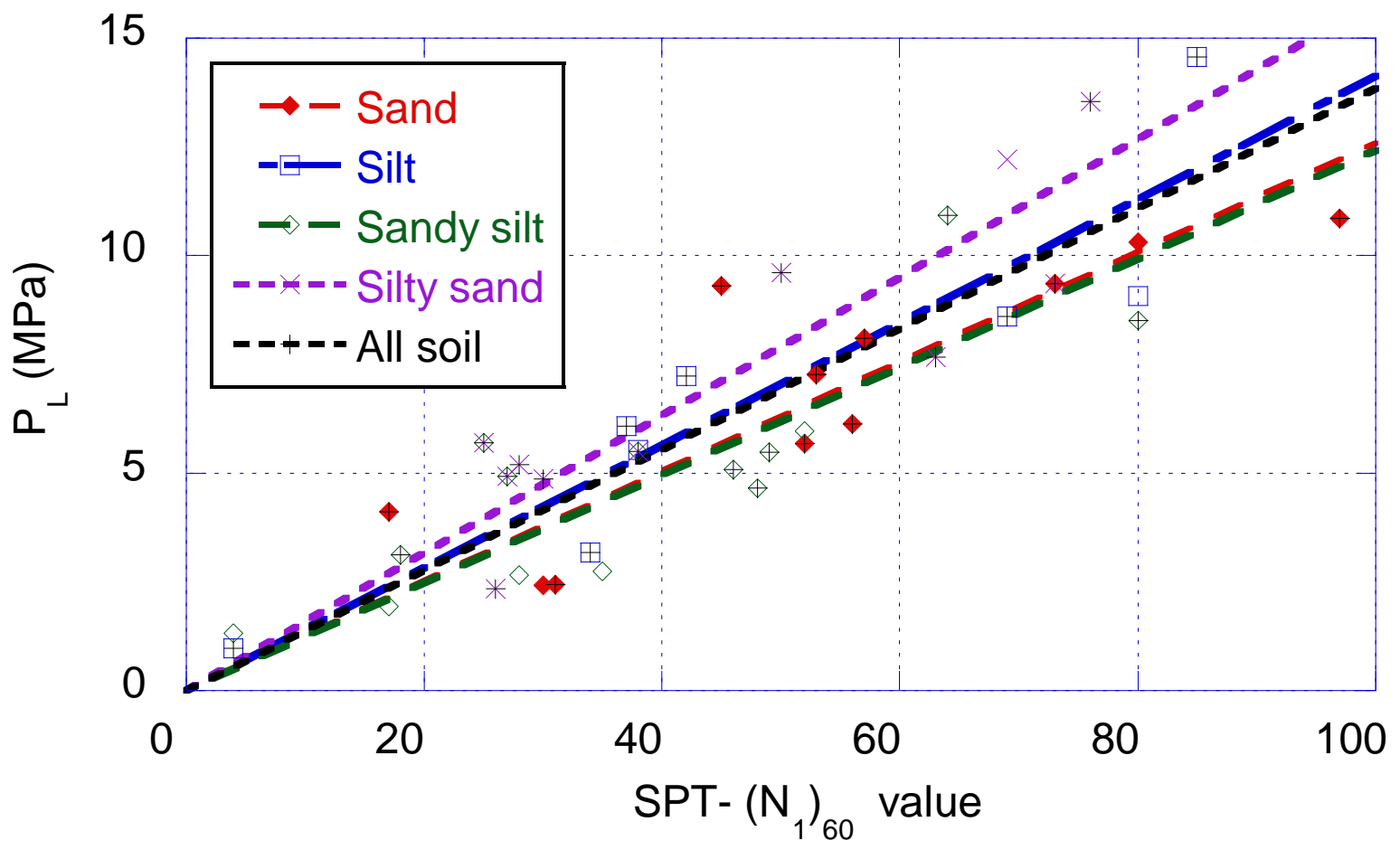

Corrected and filtered data

Figure 3.10 Correlations between SPT-N vs $\mathrm{P}_{\mathrm{L}}$ for cohesionless glacial tills 
Table 3.4 Summary of correlations between SPT-N values with both $\mathrm{E}_{\mathrm{PMT}}$ and $\mathrm{P}_{\mathrm{L}}$ values for different types of soil

\begin{tabular}{|c|c|c|c|c|}
\hline \multirow[t]{2}{*}{ Soil type } & \multicolumn{2}{|c|}{$\begin{array}{l}\text { Correlation equations }\left(\mathrm{E}_{\mathrm{PMT}}\right)(\mathrm{MPa}) \\
\left(\mathrm{R}^{2}\right)\end{array}$} & \multicolumn{2}{|c|}{$\begin{array}{l}\text { Correlation equations }\left(\mathrm{P}_{\mathrm{L}}\right) \quad(\mathrm{MPa}) \\
\left(\mathrm{R}^{2}\right)\end{array}$} \\
\hline & All data & $\begin{array}{l}\text { Corrected \& } \\
\text { Filtered data }\end{array}$ & All data & $\begin{array}{l}\text { Corrected \& } \\
\text { Filtered data }\end{array}$ \\
\hline \multicolumn{5}{|c|}{ Cohesive glacial tills } \\
\hline Silty clay & $0.87 \mathrm{~N}(0.23)$ & $1.70(N)_{60}(0.55)$ & $0.082 \mathrm{~N}(0.27)$ & $0.104(N)_{60}(0.68)$ \\
\hline Silty clay till & $1.49 \mathrm{~N}(0.72)$ & $1.37(N)_{60}(0.91)$ & $0.075 \mathrm{~N}(0.80)$ & $0.092(N)_{60}(0.89)$ \\
\hline Clayey silt till & $1.76 \mathrm{~N}(0.48)$ & $1.61(N)_{60}(0.83)$ & $0.054 \mathrm{~N}(0.19)$ & $0.104(N)_{60}(0.90)$ \\
\hline All soil & $1.65 \mathrm{~N}(0.41)$ & $1.54(N)_{60}(0.83)$ & $0.070 \mathrm{~N}(0.23)$ & $0.103(N)_{60}(0.87)$ \\
\hline \multicolumn{5}{|c|}{ Cohesionless glacial tills } \\
\hline Sand & $1.07 \mathrm{~N}(0.15)$ & $1.79\left(N_{1}\right)_{60}(0.79)$ & $0.076 \mathrm{~N}(0.16)$ & $0.126\left(N_{1}\right)_{60}(0.71)$ \\
\hline Silt & $1.13 \mathrm{~N}(0.20)$ & $1.58\left(N_{1}\right)_{60}(0.45)$ & $0.095 \mathrm{~N}(0.04)$ & $0.141\left(N_{1}\right)_{60}(0.85)$ \\
\hline Sandy silt & $1.18 \mathrm{~N}(0.46)$ & $1.68\left(N_{1}\right)_{60}(0.77)$ & $0.090 \mathrm{~N}(0.46)$ & $0.124\left(N_{1}\right)_{60}(0.67)$ \\
\hline Silty sand & $1.27 \mathrm{~N}(0.07)$ & $1.47\left(N_{1}\right)_{60}(1.0)$ & $0.093 \mathrm{~N}(0.08)$ & $0.158\left(N_{1}\right)_{60}(0.80)$ \\
\hline Sandy silt till & $1.67 \mathrm{~N}(0.37)$ & No correlation & $0.146 \mathrm{~N}(0.32)$ & No correlation \\
\hline All soil & $1.10 \mathrm{~N}(0.26)$ & $1.54\left(N_{1}\right)_{60}(0.58)$ & $0.080 \mathrm{~N}(0.26)$ & $0.139\left(N_{1}\right)_{60}(0.71)$ \\
\hline
\end{tabular}




\subsection{COMPARISONS OF CORRELATIONS BETWEEN SPT- $\left(N_{1}\right)_{60}$ VALUES AND BOTH $E_{P M T}$ AND $P_{L}$ VALUES}

There is a limited information available about the correlation between SPT-N values and both $E_{P M T}$ and $P_{L}$ for sand and clay, and is particularly sparse for glacial tills. This section presents a study on the correlation between SPT- $\left(N_{1}\right)_{60}$ values and both $\mathrm{E}_{\mathrm{PMT}}$ and $\mathrm{P}_{\mathrm{L}}$ for glacial tills in the city of Toronto. In addition, the comparison is performed between this study and the literature for sand and glacial tills. For the sand there are two types of literature models are available. The developed regression line by using corrected and filtered data is compared with available literature models. Further, another comparison of the data is performed for glacial till within the studied data. In this comparison, a linear correlation with intercept is used due to the available linear literature model.

\subsubsection{COMPARISONS OF CORRELATION BETWEEN SPT- $\left(N_{1}\right)_{60}$ VALUES AND E EMT FOR SAND}

The approximate correlation between SPT-N and $\mathrm{E}_{\mathrm{PMT}}$ proposed by Ohya et al. (1982) and Bozbey (2010) are plotted on Figure 3.11(a) with the studied data. In this comparison, a nonlinear power best fit line is plotted for the studied corrected and filtered data due to the available nonlinear literature model. For the preliminary estimation of the $\mathrm{E}_{\mathrm{PMT}}$ for the sand, the $\mathrm{E}_{\mathrm{PMT}}$ can be estimated from the SPT- $\left(N_{1}\right)_{60}$ values using the following relationship.

$\mathrm{E}_{\mathrm{PMT}}(\mathrm{MPa})=4.992\left(N_{1}\right)_{60}{ }^{0.74} \quad \mathrm{R}^{2}=0.81$

The predicted $\mathrm{E}_{\mathrm{PMT}}$ values are calculated by using "Eq. 3.1" and the measured and predicted $\mathrm{E}_{\mathrm{PMT}}$ values are also presented in Figure 3.11(a).

Another comparison of the data is performed with the research conducted by Briaud (1992), as shown in Figure 3.11(b). In this comparison a linear correlation with a zero intercept has been used due to the available linear literature model. For the preliminary estimation of the $\mathrm{E}_{\mathrm{PMT}}$ for the sand, the $\mathrm{E}_{\mathrm{PMT}}$ can be estimated from the SPT- $\left(N_{1}\right)_{60}$ values using the following relationship. 
$\mathrm{E}_{\mathrm{PMT}}(\mathrm{MPa})=1.79\left(N_{1}\right)_{60} \quad \mathrm{R}^{2}=0.79$

The predicted $\mathrm{E}_{\mathrm{PMT}}$ values are calculated by using "Eq. 3.2" and the measured and predicted values are also presented in Figure 3.11(b).

Further, a comparison of the $\mathrm{E}_{\mathrm{PMT}}$ range is performed with the research by Briaud (1992). The $E_{\text {PMT }}$ value for dense sand is greater than 22.5 MPa from Briaud (1992). In this study the E $_{\text {PMT }}$ range is $26-149 \mathrm{MPa}$. It is higher than Briaud (1992)'s value. This is because the studied sand in this project is dense to very dense with cobbles and boulders. In addition to that comparison, the range of SPT- $\left(N_{1}\right)_{60}$ value is performed with the CFEM (2006). The SPT-N value of dense sand is greater than 50 in the CFEM (2006). The mean value of SPT- $\left(N_{1}\right)_{60}$ is 50 in this study. It shows that the studied SPT- $\left(N_{1}\right)_{60}$ value of dense sand is a good agreement with CFEM (2006).

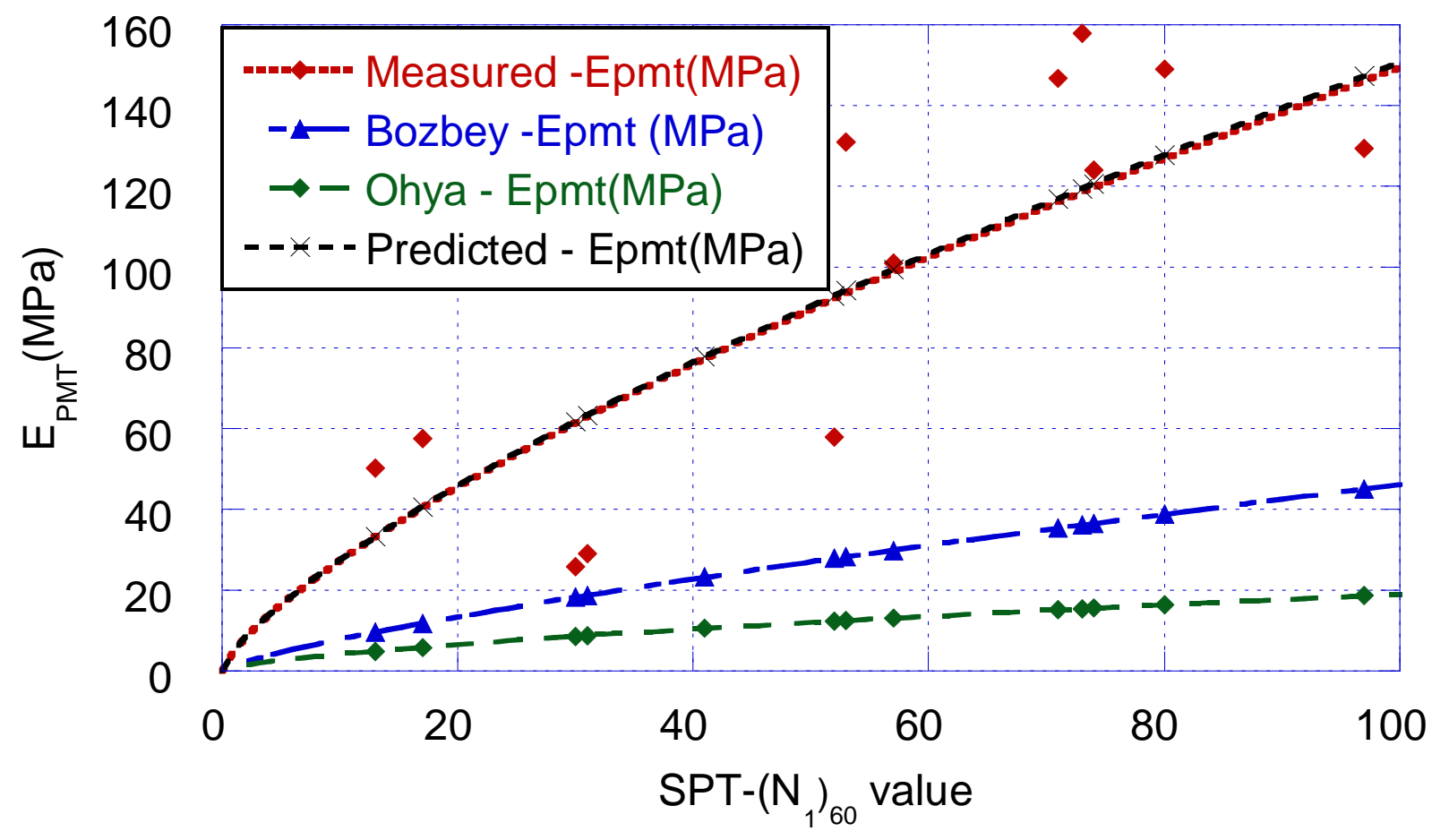

(a) Non-linear relationship 


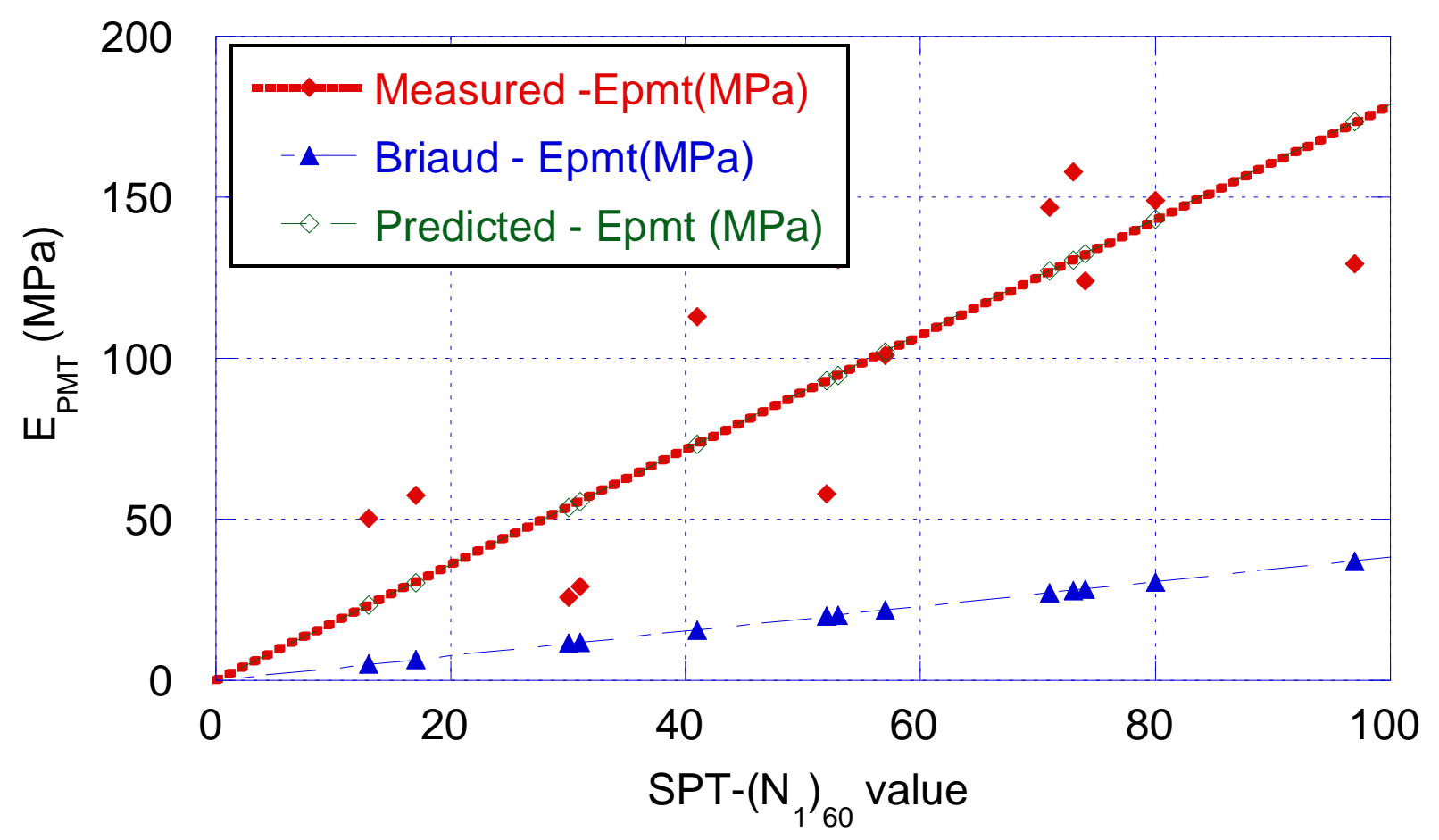

(b) Linear relationship

Figure 3.11 Comparison of correlation between SPT- $\left(N_{1}\right)_{60}$ and $\mathrm{E}_{\mathrm{PMT}}$ for sand

\subsubsection{COMPARISON OF CORRELATION BETWEEN SPT- $\left(N_{1}\right)_{60}$ VALUES AND $P_{L}$ FOR SAND}

An approximate correlation between SPT-N and $\mathrm{P}_{\mathrm{L}}$ proposed by Bozbey (2010) is plotted on Figure 3.12(a) with this investigation. In this comparison, a nonlinear power best fit line is plotted for the studied corrected and filtered data due to the nonlinearity nature of the literature model. For the preliminary estimation of the $\mathrm{P}_{\mathrm{L}}$ for the sand, the $\mathrm{P}_{\mathrm{L}}$ can be estimated from the SPT- $\left(N_{1}\right)_{60}$ values using the following relationship.

$\mathrm{P}_{\mathrm{L}}(\mathrm{MPa})=0.223\left(N_{1}\right)_{60}{ }^{0.86} \quad \mathrm{R}^{2}=0.73$

The predicted $\mathrm{P}_{\mathrm{L}}$ values are calculated by using "Eq. 3.3" and the measured and predicted values are also presented in Figure 3.12(a). 
Another comparison of the corrected and filtered data is performed with the results from Briaud (1992) and is plotted on Figure 3.12(b). In this comparison, a linear correlation with a zero intercept has been used due to the linearity nature of the literature model. For the preliminary estimation of the $\mathrm{P}_{\mathrm{L}}$ for the sand, $\mathrm{P}_{\mathrm{L}}$ can be estimated from the SPT- $\left(N_{1}\right)_{60}$ value using the following relationship.

$\mathrm{P}_{\mathrm{L}}(\mathrm{MPa})=0.126\left(\left(N_{1}\right)_{60} \quad \mathrm{R}^{2}=0.71\right.$

The predicted $\mathrm{P}_{\mathrm{L}}$ values are calculated by using "Eq. 3.4" and the measured and predicted values are also presented in Figure 3.12(b).

Further, a comparison of range of $\mathrm{P}_{\mathrm{L}}$ is performed with Briaud (1992). The $\mathrm{P}_{\mathrm{L}}$ value for dense sand is greater than 2.5 MPa from Briaud (1992). In this study the $\mathrm{P}_{\mathrm{L}}$ range is from $2.42 \mathrm{MPa}-$ 13.32 MPa. It shows that the lower limit of the range is closer to Briaud's (1992) value, but the upper limit of the range is much higher than that reported by Briaud (1992).

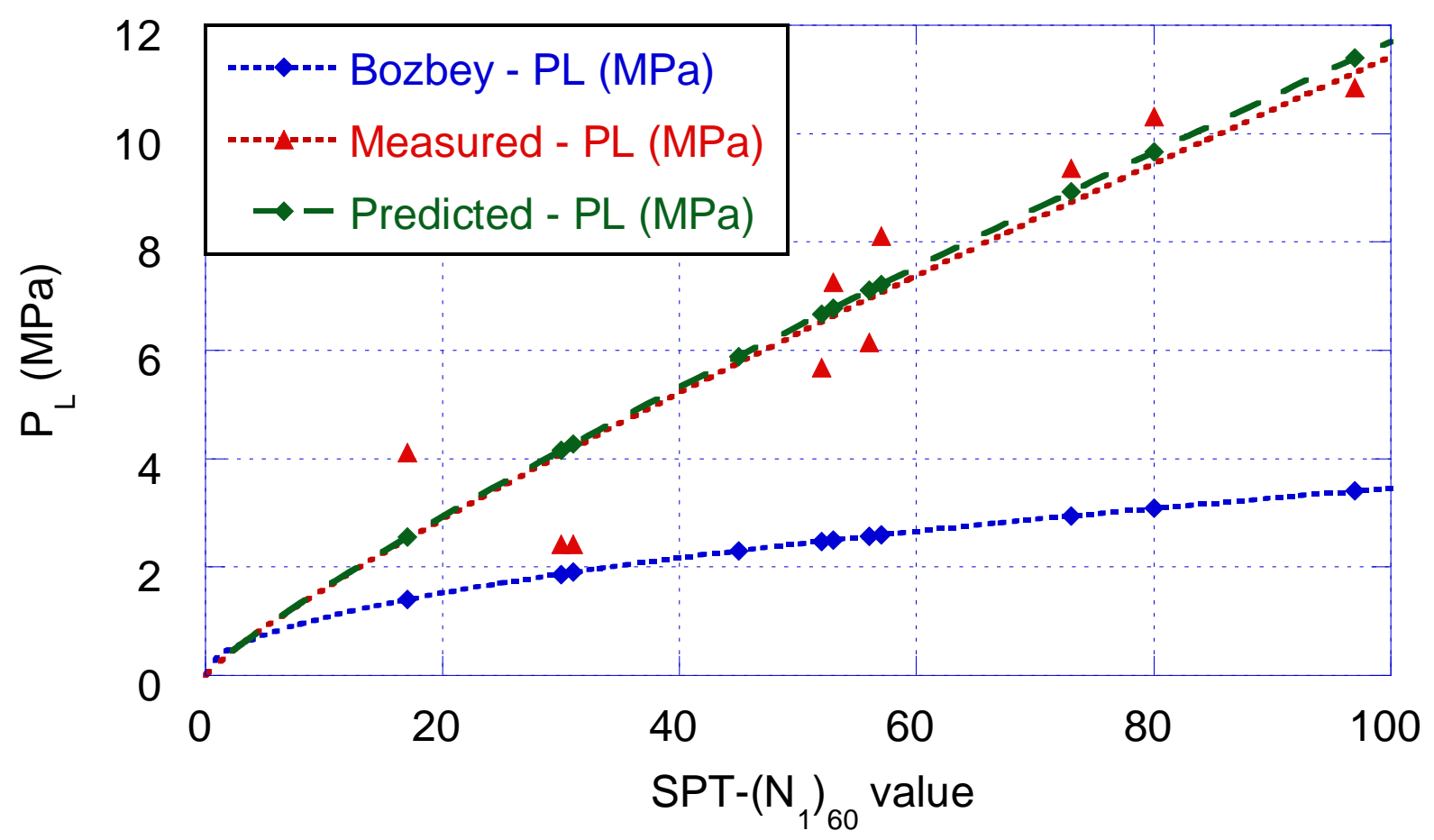

(a) Non-linear power best fit 


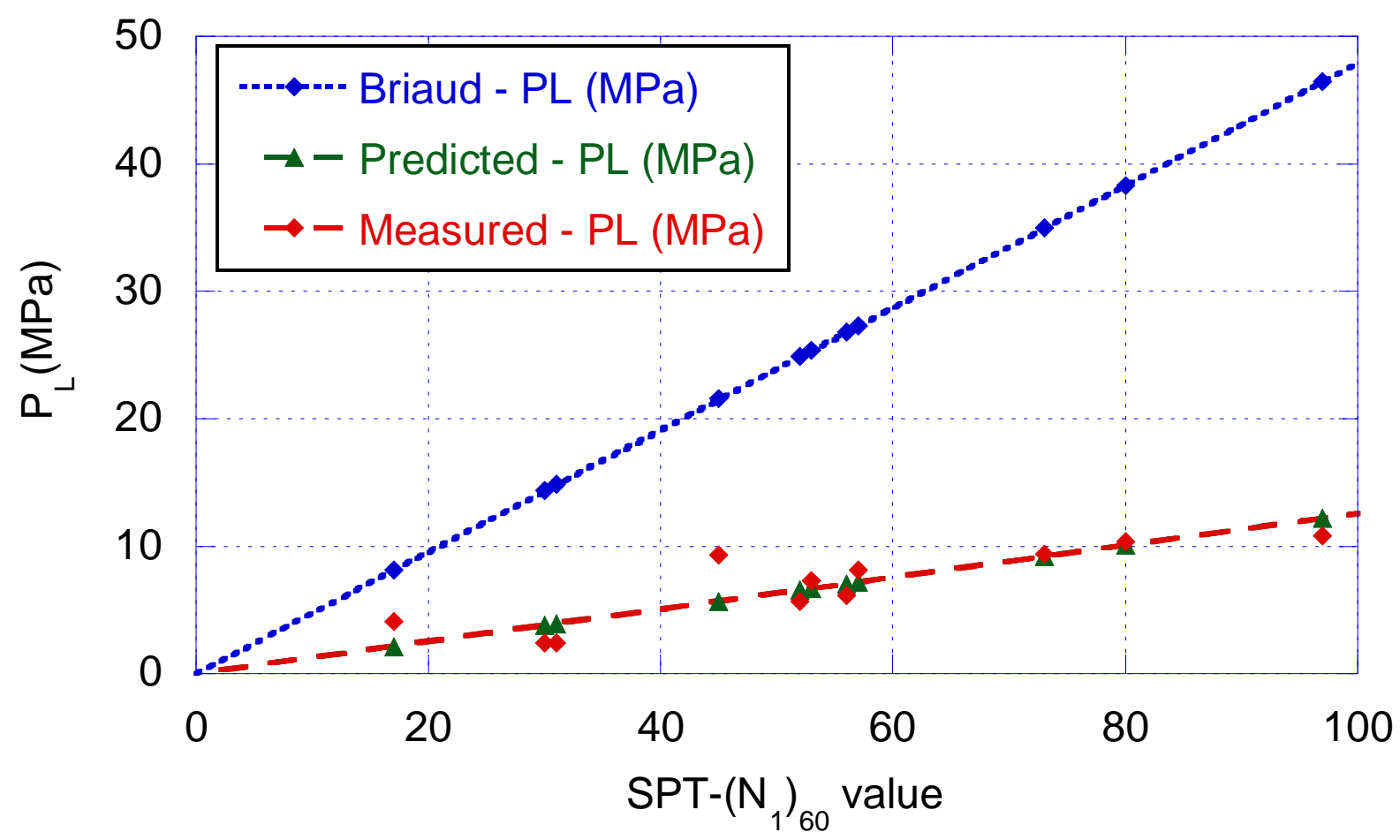

(b) Linear relationship

Figure 3.12 Comparison of correlation between SPT- $\left(N_{1}\right)_{60}$ and $\mathrm{P}_{\mathrm{L}}$ for sand

\subsubsection{COMPARISONS OF CORRELATION BETWEEN SPT- $\left(N_{1}\right)_{60}$ VALUES WITH BOTH E PMT $_{\text {AND P }}$ FOR GLACIAL TILLS}

The comparison of the corrected and filtered data is performed for glacial till with Yagiz (2008) as shown in Figure 3.13. In this comparison, a linear correlation with an intercept has been used due to the linearity nature of the literature model. For the preliminary estimation of the $\mathrm{E}_{\mathrm{PMT}}$ and $\mathrm{P}_{\mathrm{L}}$ for the glacial till, $\mathrm{E}_{\mathrm{PMT}}$ and $\mathrm{P}_{\mathrm{L}}$ can be estimated from the SPT- $\left(N_{1}\right)_{60}$ value using the following relationships.

$\mathrm{E}_{\mathrm{PMT}}(\mathrm{MPa})=1.492\left(N_{1}\right)_{60}+1.635 \quad \mathrm{R}^{2}=0.83$

$\mathrm{P}_{\mathrm{L}}(\mathrm{MPa})=0.094\left(N_{1}\right)_{60}+0.211 \quad \mathrm{R}^{2}=0.84$ 
The predicted $E_{P M T}$ and $P_{L}$ values using "Eq. 3.5" and "Eq. 3.6", and the measured $E_{P M T}$ and $P_{L}$ values, are plotted in Figure 3.13(a) and (b) respectively. The comparison shows that measured $\mathrm{E}_{\mathrm{PMT}}$ and $\mathrm{P}_{\mathrm{L}}$ are higher than the literature value. The reason for this is that the Toronto area glacial tills deposit consists of cobbles and boulders ( $\mathrm{Ng}$ et al. (2011)). The literature model equation shows $\mathrm{N}_{\text {cor.. }}$ The $\mathrm{N}_{\text {cor }}$ means, either the SPT-N is corrected for whole factors which are mentioned in the CFEM (2006) or only some factors. There are still uncertainties in this regard.

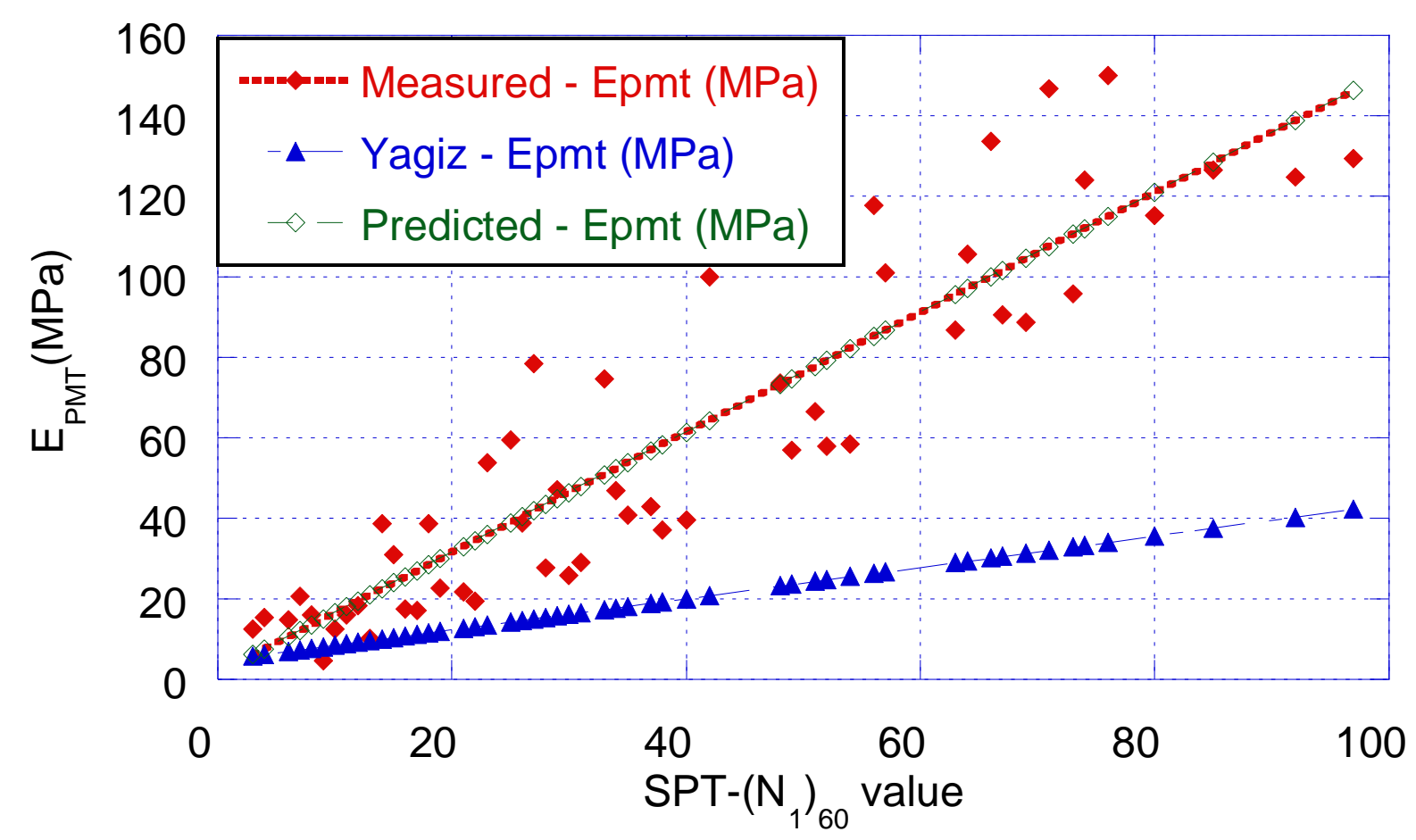

Figure 3.13(a) Comparison of correlation between SPT- $\left(N_{1}\right)_{60} \mathrm{VS}_{\mathrm{EPMT}}$ for linear with intercept relationship for glacial tills 


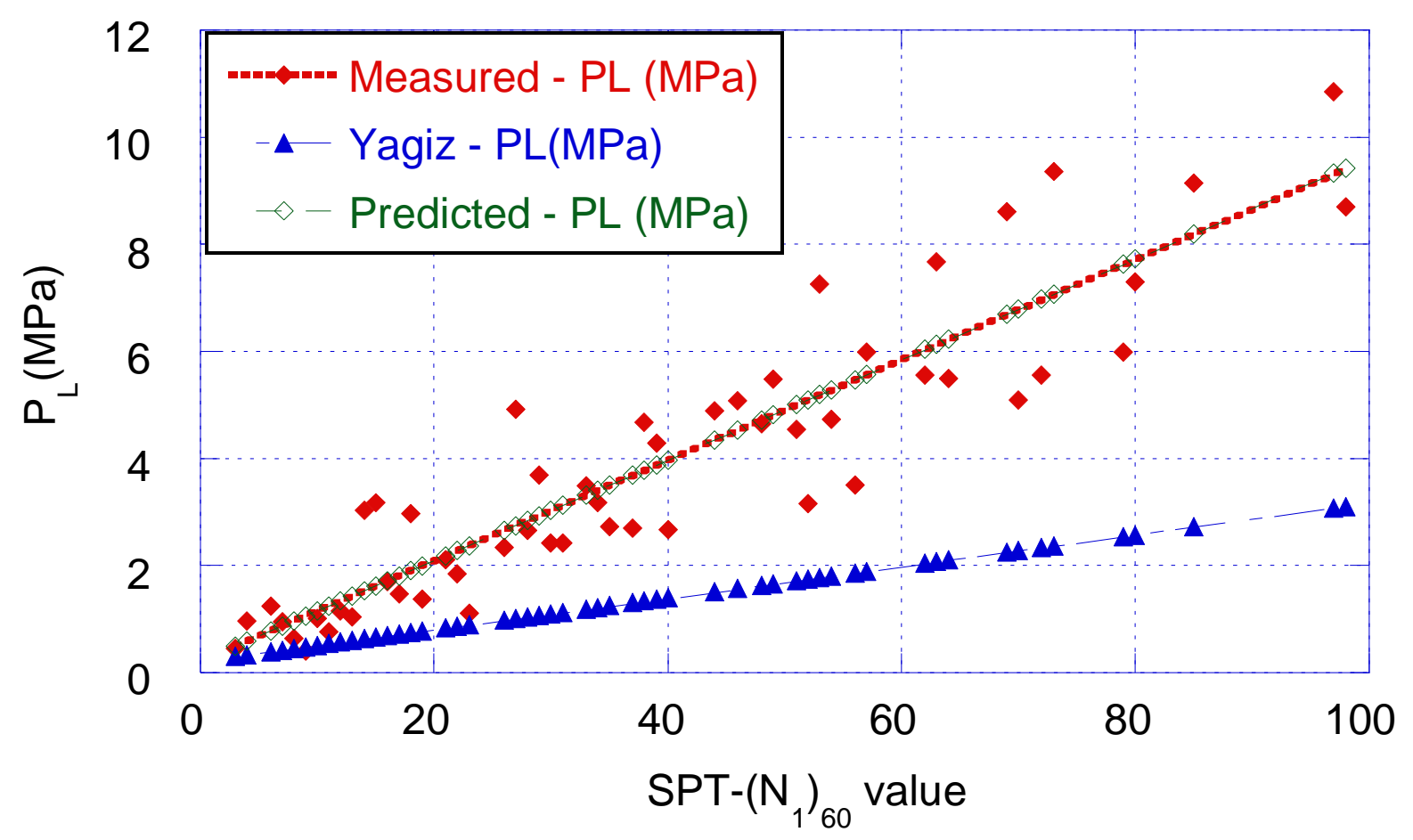

Figure 3.13 (b) Comparison of correlation between SPT- $\left(N_{1}\right)_{60}$ vs $\mathrm{P}_{\mathrm{L}}$ for linear with intercept relationship for glacial tills

\subsubsection{COMPARISONS OF CORRELATION BETWEEN SPT- $\left(N_{1}\right)_{60}$ VALUES AND $E_{P M T}$ $/ P_{L} \quad$ RATIO FOR SAND}

The range of $E_{P M T} / P_{L}$ ratio for sand is between 9 and 20, with an average of 14 and standard deviation of 4 . The $E_{P M T} / P_{L}$ ratio is compared to the studied by Bozbey (2010). The range in Bozbey's study is from 7 to 12. It shows that lower trend value differs with 2 and upper trend value differs with 8 . The studied mean value (14) is closer to the literature upper limit (12). The main reason of the difference is the compactness of the sand. The compactness of sand may vary from very loose, loose, medium, dense to very dense due to the inconsistencies. The CFEM (2006) state that the ration of $E_{P M T} / P_{L}$ for loose silty sand is 5 and sand and gravel is 7 . The $E_{P M T}$ $/ P_{L}$ ratio in this study is higher than the literature value due to the presence of gravel and cobbles in the sand. This was mentioned in the grain size analysis report which was conducted with the selected sample from the proposed ECLRT project. 
Figure 3.14 (a) represents the variation of the pressuremeter modulus with pressure limit. It is clear that the $E_{P M T}$ varies linearly with the pressure limit with a relationship of $E_{P M T}=14 P_{L}\left(R^{2}\right.$ $=0.83$ ). Further Figure 3.14 (b) represents the variation of the $E_{P M T} / P_{L}$ with SPT- $\left(N_{1}\right)_{60}$ values. It shows that the linear relationship with an intercept gives better correlation coefficient $\left(\mathrm{R}^{2}=\right.$ 0.62) compare to other relationships. The correlation equation between $E_{P M T} / P_{L}$ ratio with SPT$\left(N_{1}\right)_{60}$ is given by $E_{P M T} / P_{L}=4.964+0.192\left(N_{1}\right)_{60}$.

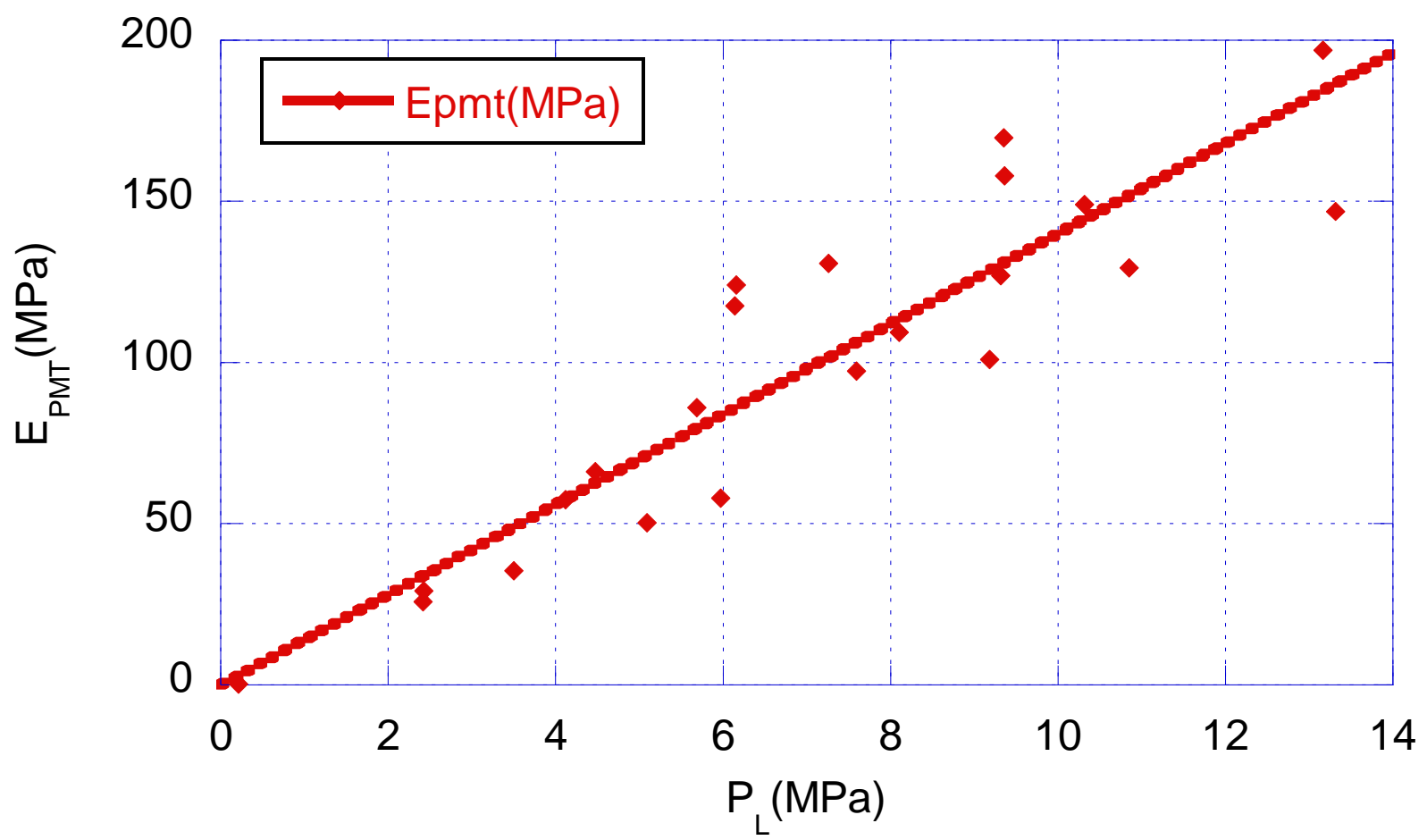

Figure 3.14 (a) Correlation between $\mathrm{E}_{\mathrm{PMT}}$ vs $\mathrm{P}_{\mathrm{L}}$ for sand 


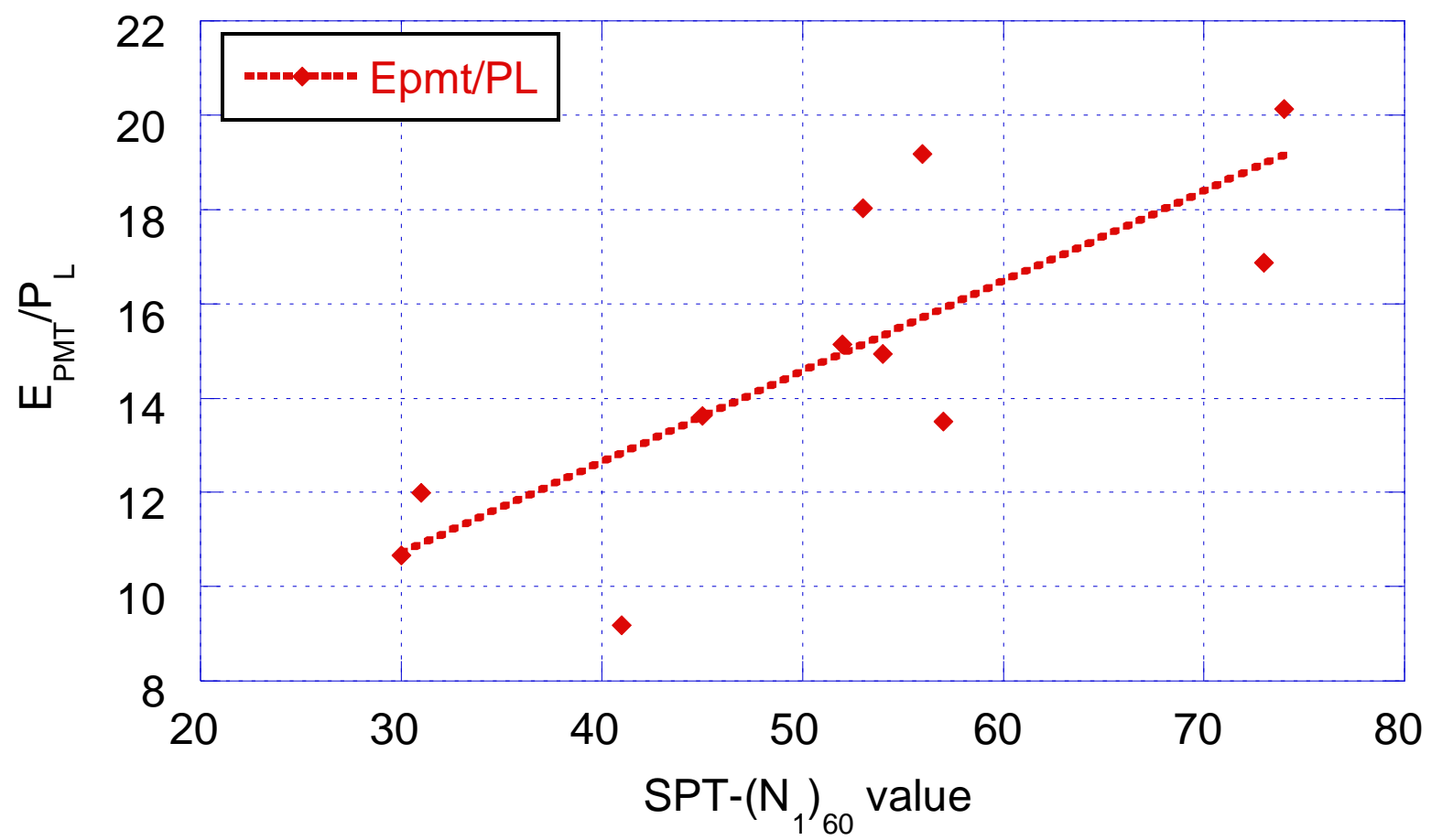

Figure 3.14 (b) Correlation between $E_{P M T} / P_{L}$ vs SPT- $\left(N_{1}\right)_{60}$ for sand

\subsubsection{COMPARISON OF CORRELATION BETWEEN SPT-(N $)_{60}$ VALUES AND $E_{P M T}$ $/ P_{L}$ RATIO FOR GLACIAL TILL}

In this study, the $E_{P M T} / P_{L}$ ratio is performed for glacial till in all stations which are mentioned in section 3.2. The range of $E_{P M T} / P_{L}$ ratio is between 5 and 26, with an average of 14 and standard deviation of 4. The comparison of $E_{P M T} / P_{L}$ ratio is performed with CFEM (2006) which shows differences with the studied range. It is stated in the literature, the many commonly used correlations in the geotechnical practice to estimate the geotechnical parameters from the in-situ tests, contains a certain amount of inaccuracy. The reasons for this result can easily be related to quality of the in-situ and laboratory tests. Since the database of this study is mainly comprised of contracted construction projects, the quality of the site explorations and testing of the soils are questionable parameters for this type of research. In addition, there is also a more important reason that affects the obtained results which is the heterogeneous nature of the soil. 
Figure 3.15 (a) represents the variation of the PMT modulus with pressure limit for glacial till. It is clear that the $\mathrm{E}_{\mathrm{PMT}}$ varies linearly with the pressure limit with a relationship of $\mathrm{E}_{\mathrm{PMT}}=14 \mathrm{P}_{\mathrm{L}}$ $\left(\mathrm{R}^{2}=0.77\right)$. Further, Figure 3.15 (b) represents the variation of $E_{P M T} / P_{L}$ with SPT- $\left(N_{1}\right)_{60}$ values. It shows that the linear relationship with an intercept gives better correlation coefficient $\left(\mathrm{R}^{2}=\right.$ 0.77). The correlation equation between $E_{P M T} / P_{L}$ ratio with $\mathrm{SPT}-\left(N_{1}\right)_{60}$ is given by $E_{P M T} / P_{L}=$ $9.304+0.140\left(N_{1}\right)_{60}$.

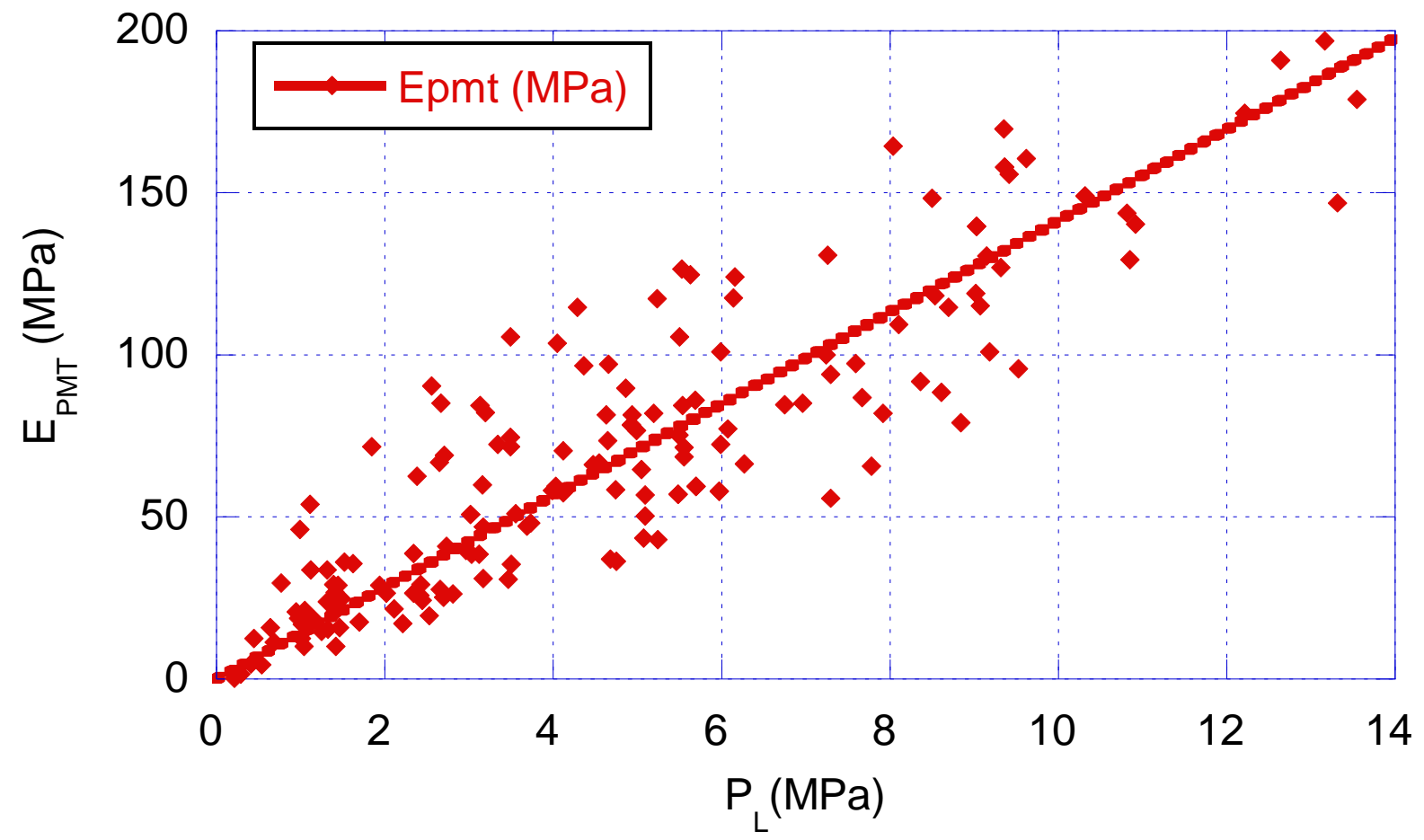

Figure 3.15 (a) Correlation between $\mathrm{E}_{\mathrm{PMT}}$ vs $\mathrm{P}_{\mathrm{L}}$ for glacial till 


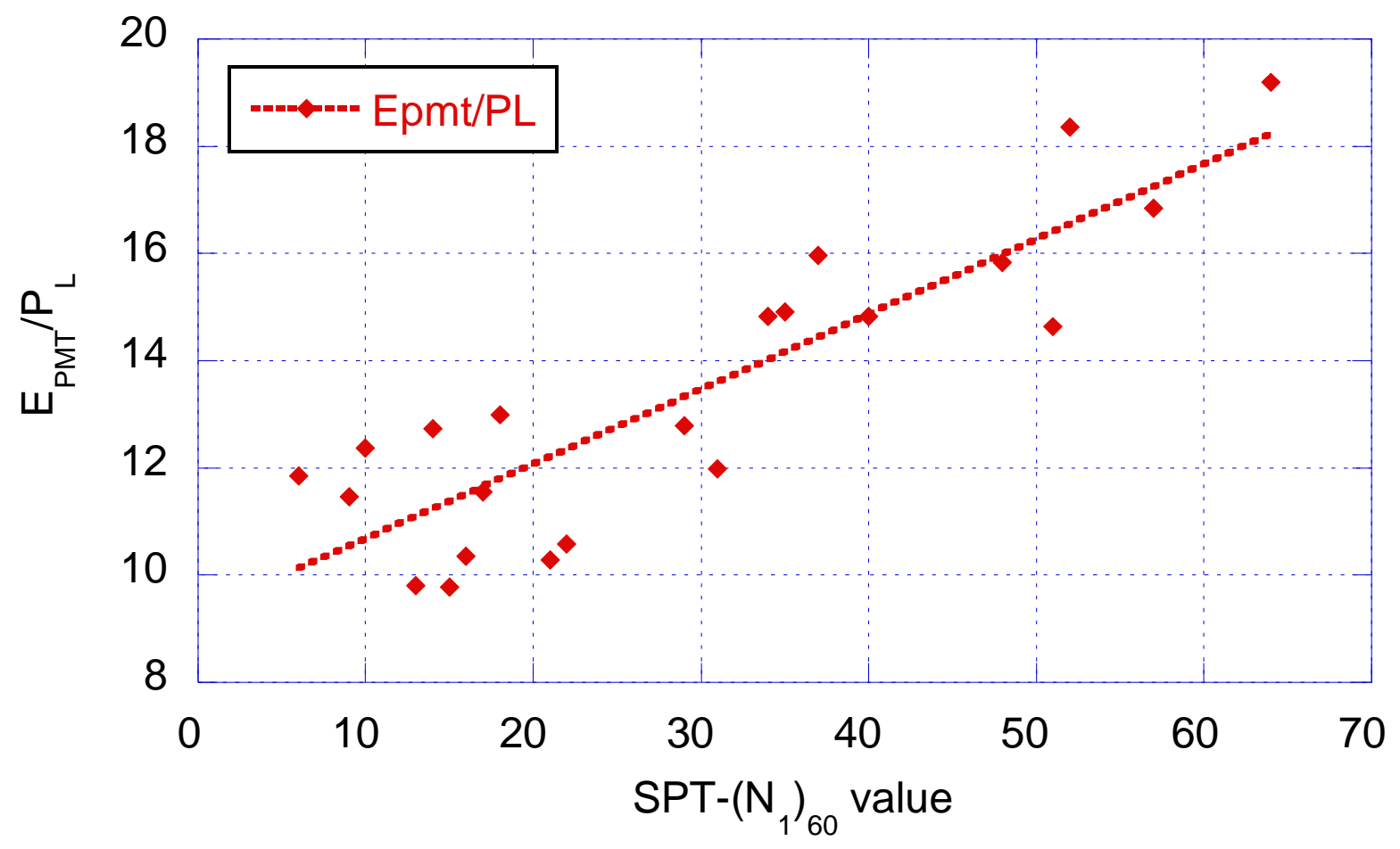

Figure 3.15 (b) Correlation between SPT- $\left(N_{1}\right)_{60}$ vs $E_{P M T} / P_{L}$ for glacial till

\subsection{SUMMARY}

In this chapter, the study is performed based on an intensive site investigation program conducted for the Eglinton Crosstown LRT Project, in the city of Toronto. Data is collected from in-situ tests such as SPT and PMT and analyzed statistically. In this chapter, an attempt is made to develop new relationships between corrected and filtered SPT-N values with both $\mathrm{E}_{\mathrm{PMT}}$ and $\mathrm{P}_{\mathrm{L}}$ for various types of glacial tills. The ranges of SPT-N, $\mathrm{E}_{\mathrm{PMT}}$ and $\mathrm{P}_{\mathrm{L}}$ values are suggested in Table 3.5. The developed new correlation equations are summarized in Table 3.6. The $E_{P M T} / P_{L}$ ratios also are summarized in Table 3.7. In addition to that the comparison is made with available literatures. There are good agreements with literature values in some extents. The accuracy of the evaluated correlations can be increased by more carefully performed and well controlled in-situ testing, borehole sampling and laboratory testing. In this way, some of the uncertainties can be reduced and the reliability of the correlations would be enhanced. 
Table 3.5 Summary of ranges of SPT-N, $\mathrm{E}_{\mathrm{PMT}}$ and $\mathrm{P}_{\mathrm{L}}$ for corrected and filtered data

\begin{tabular}{|c|c|c|c|c|c|c|}
\hline \multicolumn{7}{|c|}{ Cohesive glacial tills } \\
\hline Soil type & \multicolumn{2}{|c|}{ Silty clay } & Silty clay till & \multicolumn{2}{|c|}{ Clayey silt till } & All soil \\
\hline $\mathrm{SPT}-(N)_{60}$ & \multicolumn{2}{|l|}{$6-62$} & $3-31$ & \multicolumn{2}{|c|}{$4-67$} & $3-67$ \\
\hline $\mathrm{E}_{\mathrm{PMT}}(\mathrm{MPa})$ & \multicolumn{2}{|c|}{$11-150$} & $4-36$ & \multicolumn{2}{|c|}{$16-131$} & $4-150$ \\
\hline $\mathrm{P}_{\mathrm{L}}(\mathrm{MPa})$ & \multicolumn{2}{|c|}{$1.25-5.56$} & $0.41-5.63$ & \multicolumn{2}{|c|}{$1.00-6.00$} & $.41-6.00$ \\
\hline \multicolumn{7}{|c|}{ Cohesionless glacial tills } \\
\hline Soil type & \multicolumn{2}{|l|}{ Sand } & Sandy silt & Silty sand & Sandy silt till & All soil \\
\hline SPT- $\left(N_{1}\right)_{60}$ & $13-97$ & $4-98$ & $4-91$ & $25-76$ & $16-80$ & $4-98$ \\
\hline $\mathrm{E}_{\mathrm{PMT}}(\mathrm{MPa})$ & $26-149$ & $19-140$ & $28-78$ & $39-96$ & $18-134$ & 18-149 \\
\hline $\mathrm{P}_{\mathrm{L}}(\mathrm{MPa})$ & $2.42-13.32$ & $3.17-9.08$ & $1.33-9.03$ & $1.42-13.55$ & $6.0-8.04$ & $1.33-13.55$ \\
\hline
\end{tabular}

Table 3.6 Summary of correlation equations for $\mathrm{E}_{\mathrm{PMT}}$ and $\mathrm{P}_{\mathrm{L}}$

Cohesive glacial tills

\begin{tabular}{|c|c|c|c|c|c|c|}
\hline Soil type & Silty clay & \multicolumn{2}{|c|}{ Silty clay till } & \multicolumn{2}{|c|}{ Clayey silt till } & All soil \\
\hline $\mathrm{E}_{\mathrm{PMT}}(\mathrm{MPa})$ & $1.70 \mathrm{~N}(N)_{60}$ & \multicolumn{2}{|c|}{$1.37(N)_{60}$} & \multicolumn{2}{|c|}{$1.61(N)_{60}$} & $1.54(N)_{60}$ \\
\hline $\mathrm{P}_{\mathrm{L}}(\mathrm{MPa})$ & $0.104(N)_{60}$ & \multicolumn{2}{|c|}{$0.092(N)_{60}$} & \multicolumn{2}{|c|}{$0.104(N)_{60}$} & $0.103(N)_{60}$ \\
\hline \multicolumn{7}{|c|}{ Cohesionless glacial tills } \\
\hline Soil type & Sand & Silt & \multicolumn{2}{|c|}{ Sandy silt } & Silty sand & All soil \\
\hline $\mathrm{E}_{\mathrm{PMT}}(\mathrm{MPa})$ & $1.79\left(N_{1}\right)_{60}$ & $1.58\left(N_{1}\right)_{60}$ & \multicolumn{2}{|c|}{$1.68\left(N_{1}\right)_{60}$} & $1.47\left(N_{1}\right)_{60}$ & $1.54\left(N_{1}\right)_{60}$ \\
\hline $\mathrm{P}_{\mathrm{L}}(\mathrm{MPa})$ & $0.126\left(N_{1}\right)_{60}$ & $0.141\left(N_{1}\right)_{60}$ & \multicolumn{2}{|c|}{$0.124\left(N_{1}\right)_{60}$} & $0.158\left(N_{1}\right)_{60}$ & $0.139\left(N_{1}\right)_{60}$ \\
\hline
\end{tabular}

Table 3.7 Summary of $E_{P M T} / P_{L}$ ratio for corrected and filtered data

\begin{tabular}{|c|c|}
\hline Soil type & $E_{P M T} / P_{L}$ Ratio \\
\hline Sand & $9-20$ \\
\hline Glacial till & $5-26$ \\
\hline
\end{tabular}




\section{CHAPTER 4: FINITE ELEMENT SIMULATIONS OF PMTS}

\subsection{INTRODUCTION}

The main aim of this chapter is to back calculate the PMT modulus ( $\mathrm{E}_{\mathrm{PMT}}$ ) by using the finite element method (FEM) software, Plaxis 2D. For this purpose Mohr-Coulomb (M-C) model is used. The modelling methods and procedures of using Plaxis 2D are discussed in Section 4.2. The description of the M-C model is discussed in Section 4.3. The Section 4.4 described the 2D - PMT modeling and verification. In this section the PMT model is verified by existing literature model (Levasseur et al. (2009)). There is a good agreement between both models. In Section 4.5, the sensitivity study is performed to investigate the influence of mesh coarseness and boundary conditions. In Section 4.6, the case study is performed based on extensive PMTs are conducted in the Mount Dennis (MD) Station in the ECLRT project in Toronto. In this section, the PMT modulus $\left(\mathrm{E}_{\mathrm{PMT}}\right)$ is calculated for different types of glacial tills according to the borehole \# MD 101 with assumed values of Young's modulus. Then the PMT modulus ( $\left.\mathrm{E}_{\mathrm{PMT}}\right)$ is correlated with the Young's modulus (E) for various types of glacial tills. The Menard's rheological factor $(\alpha)$ is made for each type of glacial tills. Finally the results are summarized in Section 4.7.

\subsection{FINITE ELEMENT METHOD}

FEM plays a major role in the geotechnical engineering practice because it allows modeling complicated nonlinear soil behavior through constitutive models. It will handle complex problems where analytical solutions are nearly impossible. Nowadays, the FEM has become very popular in the geotechnical engineering design. Even though, before the FEM can be used in design, the accuracy of any proposed solution technique must be proved (Owen and Hinton (1980)). In the FEM, the study object is divided into a number of finite elements, and the interaction between each one of these elements is analyzed for various geometrics with different boundary conditions and interfaces. It can predict the stresses, deformations and pore pressures of a specified soil profile. 


\subsubsection{CONSTITUTIVE BEHAVIOUR}

The constitutive behavior is the stress-strain behavior. The 3D constitutive equations (Eqs. 4.1 4.3) can be used to calculate the stresses in a soil mass with neglecting the inertia effects and all body forces except the self-weight $y$ in $x$ (vertical) direction (Timoshenko and Goodier (1951)). Equilibrium equations (Eqs. 4.1 - 4.3) are in terms of total stresses that must satisfy the boundary conditions. Fig. 4.1 shows the stresses on a typical element. Compressive stresses are considered as positive.

$$
\begin{aligned}
& \frac{\partial \sigma_{X}}{\partial X}+\frac{\partial \tau_{Y X}}{\partial Y}+\frac{\partial \tau_{Z X}}{\partial Z}+\gamma=0 \\
& \frac{\partial \tau_{X Y}}{\partial X}+\frac{\partial \sigma_{Y}}{\partial Y}+\frac{\partial \tau_{Z Y}}{\partial Z}=0 \\
& \frac{\partial \tau_{X Z}}{\partial X}+\frac{\partial \tau_{Y Z}}{\partial Y}+\frac{\partial \sigma_{Z}}{\partial Z}=0
\end{aligned}
$$

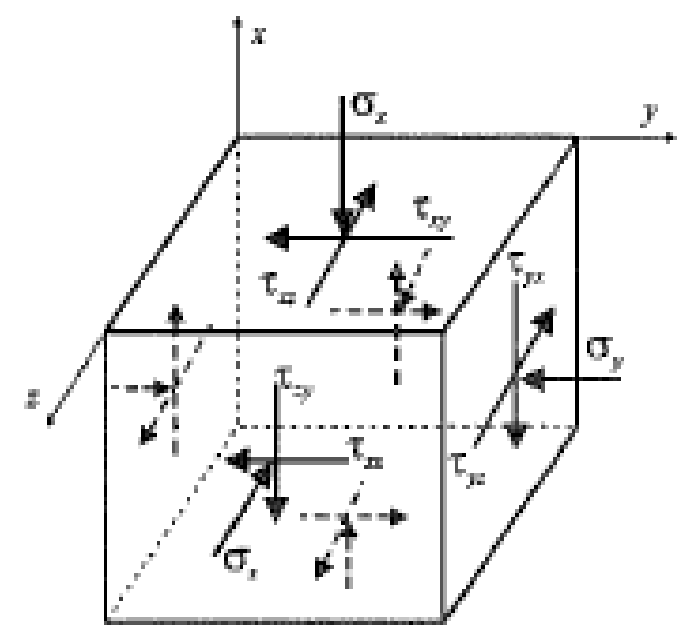

Figure 4.1 Stresses on a typical element

In the equilibrium and compatibility conditions, the constitutive behavior of a soil can be expressed mathematically as Eqs.4.4 or Eqs.4.5.

$$
\Delta \sigma=[D] \Delta \varepsilon
$$




$$
\left\{\begin{array}{l}
\Delta \sigma_{X} \\
\Delta \sigma_{Y} \\
\Delta \sigma_{Z} \\
\Delta \tau_{X Y} \\
\Delta \tau_{X Z} \\
\Delta \tau_{Z Y}
\end{array}\right\}=\left[\begin{array}{llllll}
D_{11} & D_{12} & D_{13} & D_{14} & D_{15} & D_{16} \\
D_{21} & D_{22} & D_{23} & D_{24} & D_{25} & D_{26} \\
D_{31} & D_{32} & D_{33} & D_{34} & D_{35} & D_{36} \\
D_{41} & D_{42} & D_{43} & D_{44} & D_{45} & D_{46} \\
D_{51} & D_{52} & D_{53} & D_{54} & D_{55} & D_{56} \\
D_{61} & D_{62} & D_{63} & D_{64} & D_{65} & D_{66}
\end{array}\right]\left\{\begin{array}{l}
\Delta \varepsilon_{X} \\
\Delta \varepsilon_{Y} \\
\Delta \varepsilon_{Z} \\
\Delta \gamma_{X Y} \\
\Delta \gamma_{X Z} \\
\Delta \gamma_{Z Y}
\end{array}\right\}
$$

For a linear elastic material, the [D] matrix is written as Eqs.4.6.

$$
[D]=\frac{E}{(1+v)(1-2 v)}\left[\begin{array}{ccccccc}
1-v & v & v & 0 & 0 & 0 \\
& 1-v & v & 0 & 0 & 0 \\
& & 1-v & 0 & 0 & 0 \\
& & & \frac{1-2 v}{2} & 0 & 0 \\
& & & & \frac{1-2 v}{2} & 0 \\
\text { Symmetry } & & & & \frac{1-2 v}{2}
\end{array}\right]
$$

Where

$$
\begin{aligned}
& E \text { - Modulus of elasticity } \\
& \text { v- Poisson's ratio }
\end{aligned}
$$

However, the soil behavior is usually non-linear. Therefore, increments of stress and strain can be more realistically related using the constitutive equation as indicated in Eq. 4.4 (Potts and Zdravkovic (2001)). It is also realistic for the $[D]$ matrix to depend on the current and past history. The constitutive behavior can be stated by means of total or effective stresses. If it is needed to specify the constitutive behavior in terms of effective stress, the principle of effective stress can be used to obtain total stresses required for use with equilibrium equations (Eqs.4.7 4.10)

$$
\begin{aligned}
& \sigma=\sigma^{\prime}+\sigma_{f} \\
& \Delta \sigma^{\prime}=\left[D^{\prime}\right] \Delta \varepsilon
\end{aligned}
$$




$$
\Delta \sigma_{f}=\left\lfloor D_{f}\right\rfloor \Delta \varepsilon
$$

Therefore,

$$
\Delta \sigma=\left(\left[D^{\prime}\right]+\left\lfloor D_{f}\right\rfloor\right) \Delta \varepsilon
$$

Where

$\sigma$ - Total stress

$\sigma^{\prime}-$ Effective stress

$\sigma_{\mathrm{f}}$ - Pore fluid pressure

$\mathrm{D}^{\prime}$ - Constitutive relationship relating the change in effective stress to the change in strain $D_{f}$ - Constitutive relationship relating the change in pore fluid pressure to the change in strain

\section{Plain strain condition}

The constitutive relationship Eq 4.5 can be reduced to Eq 4.11 as follows for plain strain conditions.

$$
\left\{\begin{array}{l}
\Delta \sigma_{x} \\
\Delta \sigma_{y} \\
\Delta \sigma_{z} \\
\Delta \tau_{x y} \\
\Delta \tau_{x z} \\
\Delta \tau_{z y}
\end{array}\right\}=\left[\begin{array}{lll}
D_{11} & D_{12} & D_{14} \\
D_{21} & D_{22} & D_{24} \\
D_{31} & D_{32} & D_{34} \\
D_{41} & D_{42} & D_{44} \\
D_{51} & D_{52} & D_{54} \\
D_{61} & D_{62} & D_{64}
\end{array}\right]\left\{\begin{array}{l}
\Delta \varepsilon_{x} \\
\Delta \varepsilon_{y} \\
\Delta \gamma_{x y}
\end{array}\right\}
$$

\section{Axisymmetric condition}

In the case of axisymmetric problems, it is usual to carry out analyses using cylindrical coordinates as shown in Figure 4.2, $\mathrm{r}$ (radial direction), $\mathrm{z}$ (vertical direction) and $\theta$ (circumference direction). Due to the symmetry, there is no displacement in the $\theta$ direction and the displacement in the $\mathrm{r}$ and $\mathrm{z}$ directions are independent of $\theta$ and therefore the strains reduce to Eq 4.12 (Timoshenko and Goodier (1951)). 


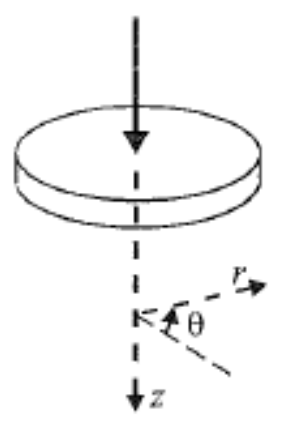

Fig 4.2 Example of axisymmetric co-ordinate axis

$$
\varepsilon_{r}=-\frac{\partial u}{\partial r} ; \varepsilon_{z}=-\frac{\partial v}{\partial z} ; \varepsilon_{0}=-\frac{u}{r} ; \gamma_{r z}=-\frac{\partial v}{\partial r}-\frac{\partial u}{\partial z} ; \gamma_{r 0}=\gamma_{z 0}=0
$$

Where $\mathrm{u}$ and $\mathrm{v}$ are the displacements in the $\mathrm{r}$ and $\mathrm{z}$ direction respectively.

Stresses in the axisymmetric element are shown in Figure 4.3 and the [D] matrix is similar to plain strain situation as shown in the Eq 4.11.

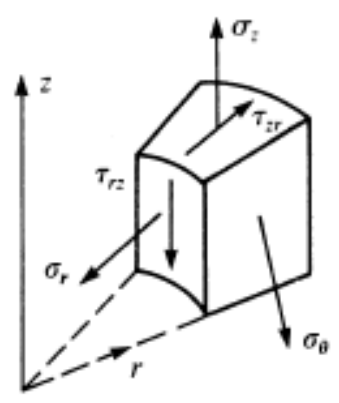

Fig 4.3 Stresses in the axisymmetric element

\subsubsection{STEPS INVOLVED IN THE FEM}

The following steps are involved in the FEM (Potts and Zdravkovic (2001)).

\section{Step 1: Element discretization}

In this process, the geometry of the problem is modelled by an assembly of small regions termed as finite elements, which have nodes defined on the element boundaries, or within the element. 


\section{Step 2: Primary variable approximation}

Primary variables such as displacements, stresses, etc., must be selected. The rules with regard to how these variables have to vary over a finite element are established. Nodal values are used to express the variations. Displacements are usually adopted as a primary variable in geotechnical engineering.

\section{Step 3: Element equations}

The elemental equations (Eq. 4.13) are derived using an appropriate variational principle (e.g., the minimum potential energy).

$$
\left[K_{E}\right]\left\{\Delta d_{E}\right\}=\left\{\Delta R_{E}\right\}
$$

Where

$\left[K_{E}\right]$ - Element stiffness matrix

$\left\{\Delta d_{E}\right\}$ - Vector of incremental element nodal displacements

$\left\{\Delta R_{E}\right\}$-Vector of incremental element nodal forces

\section{Step 4: Global equations}

The element equations are combined to form global equations (Eq. 4.14).

$$
\left[K_{G}\right]\left\{\Delta d_{G}\right\}=\left\{\Delta R_{G}\right\}
$$

Where

$\left[K_{G}\right]$ - Global stiffness matrix

$\left\{\Delta d_{G}\right\}$-Vector of all incremental global nodal displacements

$\left\{\Delta R_{G}\right\}$ - Vector of all incremental global nodal forces 


\section{Step 5: Boundary conditions}

The global equations are modified by formulating boundary conditions. Loadings such as line and point loads, pressures, body forces, etc. affect $\left\{\Delta R_{G}\right\}$, and the displacements affect $\left\{\Delta d_{G}\right\}$.

\section{Step 6: Solve the global equations}

The displacements $\left\{\Delta d_{G}\right\}$ at all the nodes can be obtained by solving the global equations. These nodal displacements are used to evaluate stresses and strains.

\subsection{MOHR-COULOMB MATERIAL MODEL}

In this research, the Mohr-Coulomb (M-C) elastoplastic constitutive model is used as a material model for soils. The basic parameters used in this model with their standard units are listed below.

E : Young's modulus

$\left[k N / m^{2}\right]$

v : Poisson's ratio

c : Cohesion

$\left[k N / m^{2}\right]$

$\varphi \quad$ : Frictionangle

$\psi \quad$ : Dilatancy angle

As shown in Fig. 4.4, the Mohr circles of stress at failure are obtained by plotting the results of the laboratory tests in term of effective stresses. The tangent line to the failure circles from several tests, performed with different initial effective stresses, is called the Coulomb failure criterion (Eqs. $4.15-4.17)$.

$$
\tau_{f}=c^{\prime}+\sigma_{n f}^{\prime} \tan \varphi^{\prime}
$$

Where

$\tau_{f}$-Shear stress on the failure plane 
$\sigma_{n f}^{\prime}$-Normal effective stress on the failure plane

$c^{\prime}$-Cohesion

$\varphi^{\prime}$-Angle of shearing resistance

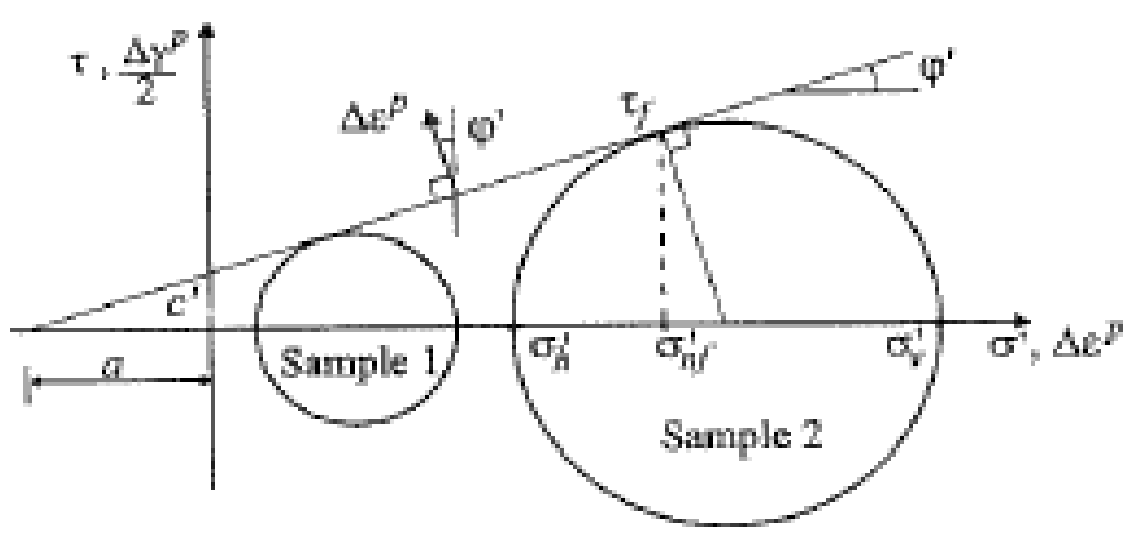

Figure 4.4 Mohr's circles of effective stress (Ports and Zdravkovic (2001))

The M-C failure criterion is defined as:

$$
\begin{aligned}
& \sigma_{1}{ }^{\prime}-\sigma_{3}{ }^{\prime}=2 c^{\prime} \cos \varphi^{\prime}+\left(\sigma_{1}{ }^{\prime}+\sigma_{3}{ }^{\prime}\right) \sin \varphi^{\prime} \\
& \sigma_{1}{ }^{\prime}=\sigma_{v}{ }^{\prime}, \text { and } \sigma_{3}{ }^{\prime}=\sigma_{h}{ }^{\prime}
\end{aligned}
$$

Therefore, the yield function is given below

$$
F\left(\left\{\sigma_{1}^{\prime}\right\},\{k\}\right)=\sigma_{1}^{\prime}-\sigma_{3}^{\prime}-2 c^{\prime} \cos \varphi^{\prime}-\left(\sigma_{1}^{\prime}+\sigma_{3}{ }^{\prime}\right) \sin \varphi^{\prime}
$$

This equation can be more conveniently written in terms of stress invariants $p^{\prime}, J$, and $\theta$ (Eqs. $4.18-4.19)$.

$$
F\left(\left\{\sigma_{1}^{\prime}\right\},\{k\}\right)=J-\left[\left(\frac{c^{\prime}}{\tan \varphi^{\prime}}\right)+p^{\prime}\right] g(\theta)=0
$$




$$
g(\theta)=\frac{\sin \phi^{\prime}}{\cos \theta+\left(\frac{\sin \theta \sin \phi^{\prime}}{\sqrt{3}}\right)}
$$

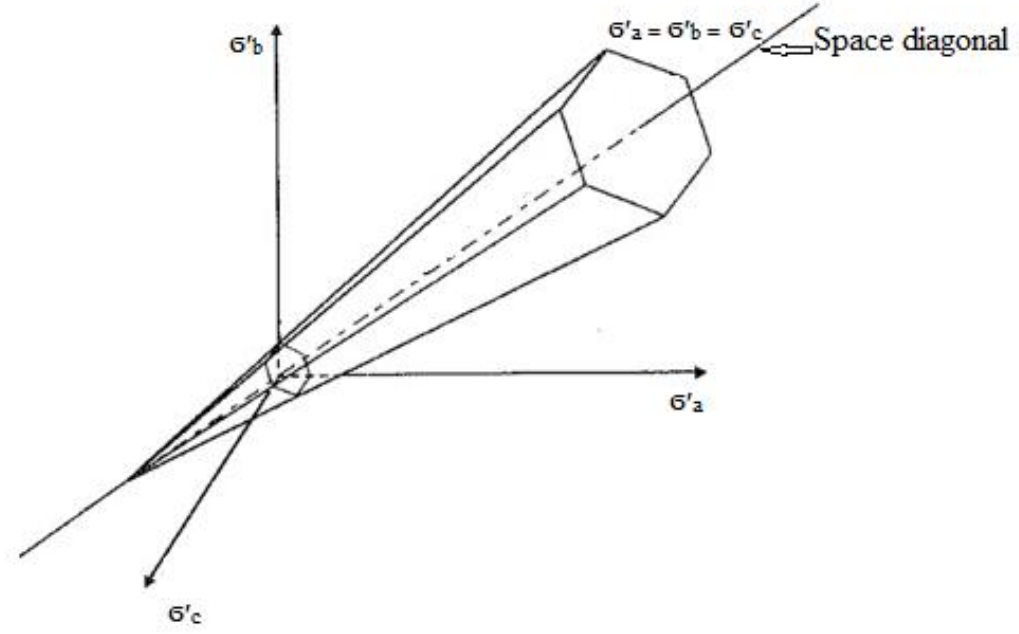

Figure 4.5 Mohr-Coulomb yield surfaces in principal stress space (Ports and Zdravkovic (2001))

As shown in Figure 4.5, an irregular hexagonal cone is plotted by the yield function in principal effective stress space.

\subsection{D PMT MODELLING AND VERIFICATION}

\subsubsection{D PMT MODELLING}

For the 2D PMT modeling, the FEM software, PLAXIS 2D, is used. PLAXIS name was derived from PLasticity AXISymmetry, a computer program developed to solve the cone penetrometer problem by Pieter Vermeer and De borst. According to (Burd (1999)), the initiation of this program was held at Delft University of Technology Netherland by Pieter Vermeer in 1974. Earlier version of PLAXIS was in DOS interface. In 1998, the first PLAXIS 2D for Windows was released. The new versions and modifications were carried out for the analysis of soil behavior for geotechnical engineers. In this study Plaxis 2D version 2012 is used. 


\subsubsection{VERIFICATION OF THE MODEL}

The 2D FEM model is validated by using a published case study on PMT, which was performed by Levasseur et al. (2009) for Hostun sand. The geometry of the model is shown in Figure 4.6. The PMT test depth is $3 \mathrm{~m}$. In this analysis, an axisymmetric FEM is used which is the same as the way used by Levasseur et al. (2009). In this model, the soil is represented by an M-C model whose parameters are shown in Table 4.1. To validate the model same soil parameters are used with same soil model as M-C by using Plaxis $2 \mathrm{D}$ in this verification study. The geometry of the model has shown in Figure 4.7. The deformed mesh diagram and the zoomed view of the diagram are shown in Figure 4.8 and Figure 4.9 respectively. The horizontal displacement diagram and the zoomed view of the diagram are also shown in Figure 4.10 to Figure 4.11 individually. The pressure $(\mathrm{P})$ vs volumetric strain $\left(\frac{\Delta v}{V}\right)$ curve is plotted with the curve from the literature. There is a good agreement between the two curves, as shown in Figure 4.12.

Table 4.1 Parameters used in the M-C model for dense Hostun sand

\begin{tabular}{|c|c|}
\hline Parameter & Levasseur et al. (2009) value \\
\hline Shear modulus $\left(\mathrm{G}_{\text {ref }}\right)(k P a)$ & 22250 \\
\hline Poisson's coefficient $(v)$ & 0.25 \\
\hline Cohesion $(\mathrm{c})(\mathrm{kPa})$ & 0 \\
\hline Friction angle $(\varphi)\left({ }^{0}\right)$ & 35 \\
\hline Dilatancy angle $(\psi)\left({ }^{0}\right)$ & 5 \\
\hline Initial stress field coefficient $\left(\mathrm{K}_{0}\right)$ & 0.4265 \\
\hline
\end{tabular}




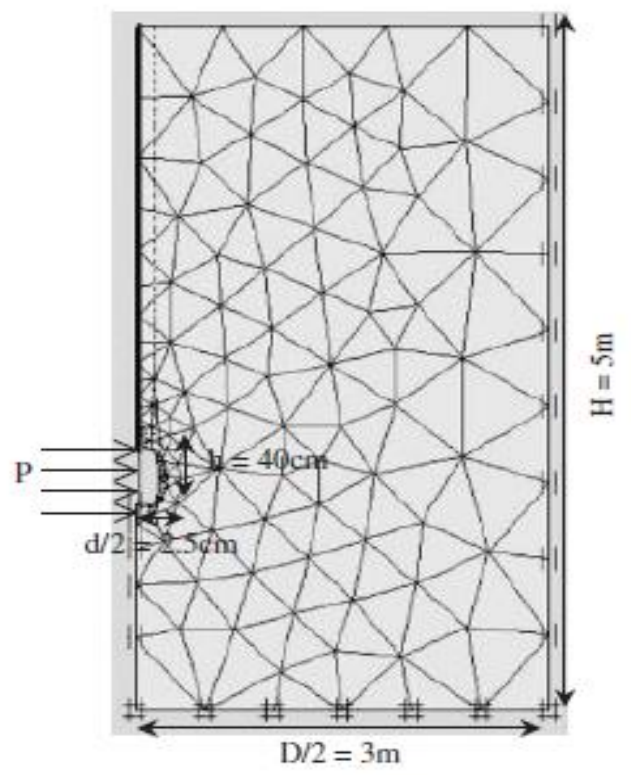

Figure 4.6 2D axisymmetric model and associated mesh (Levasseur et al. (2009))

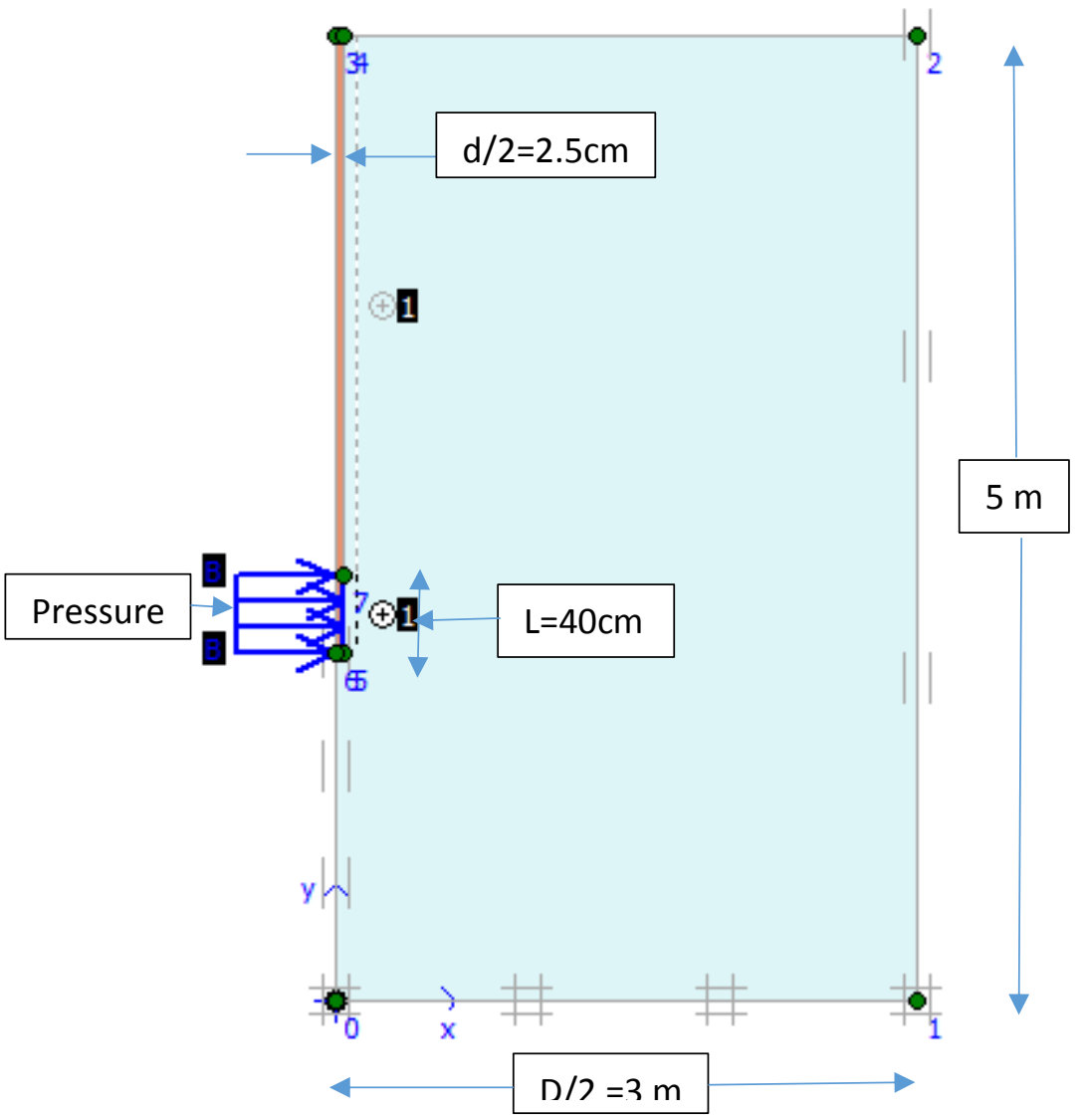

Figure 4.7 Geometry of the PMT model 


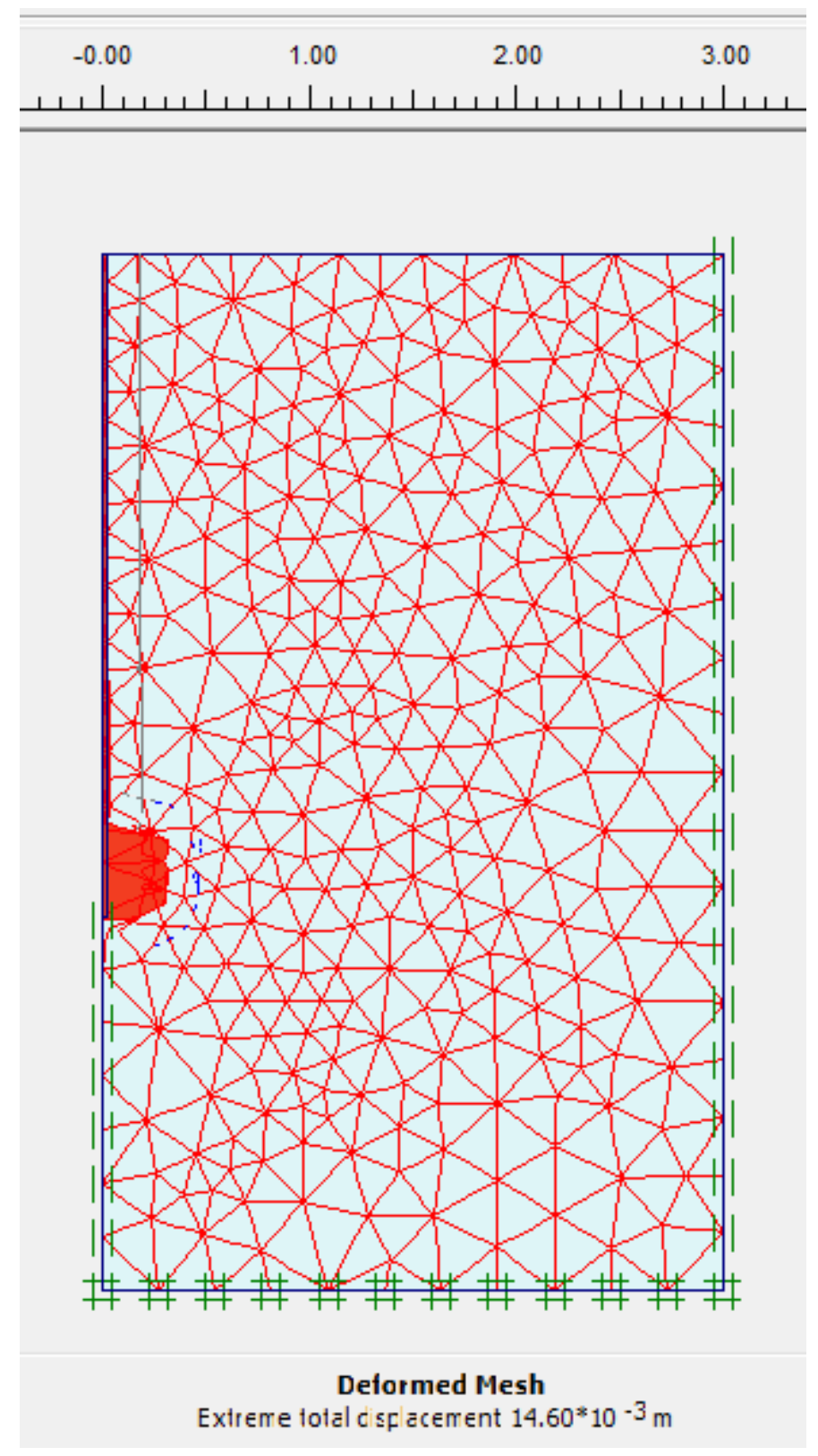

Figure 4.8 Deformed mesh diagram 


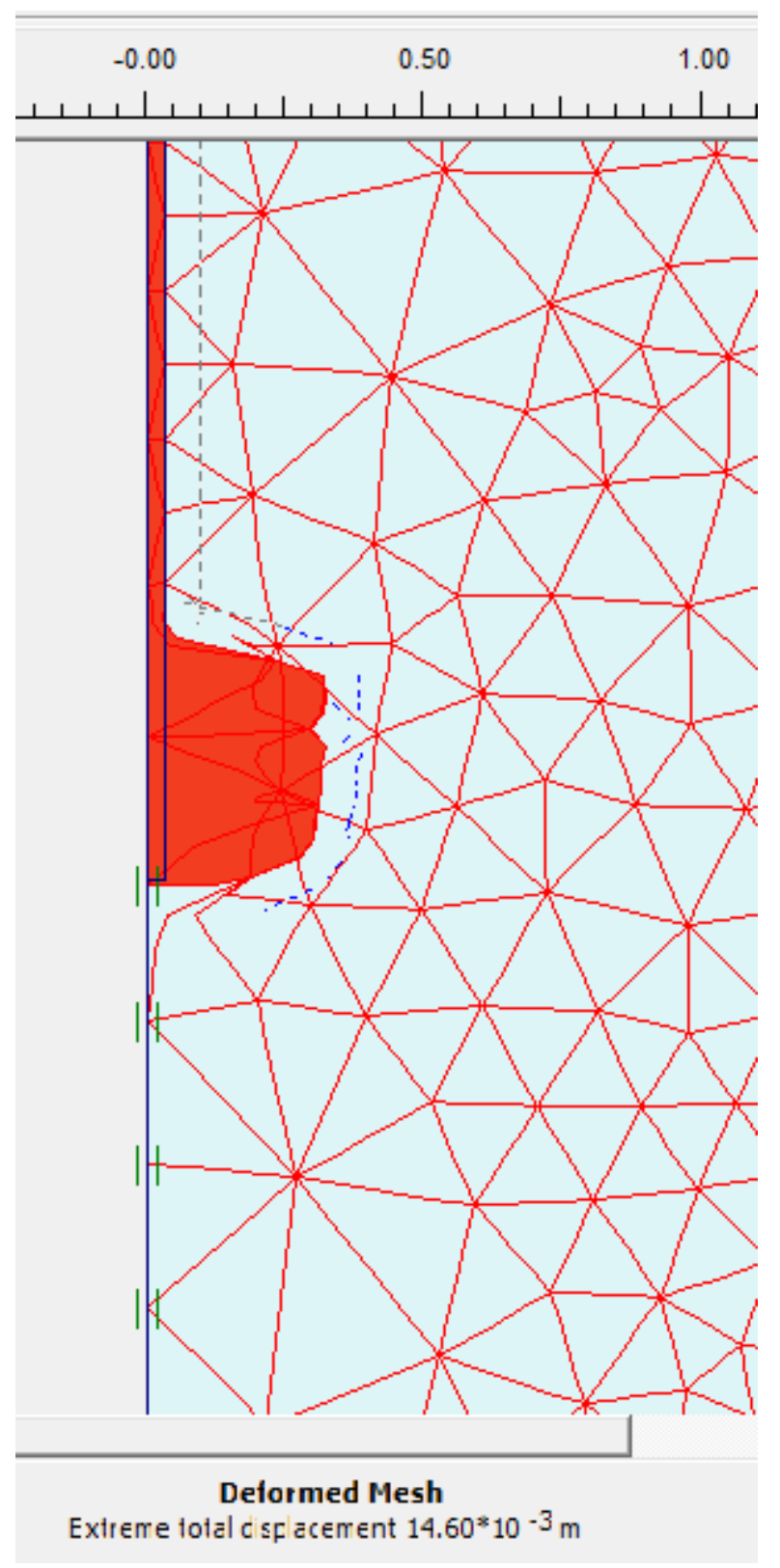

Figure 4.9 Zoomed view of the deformed mesh diagram 


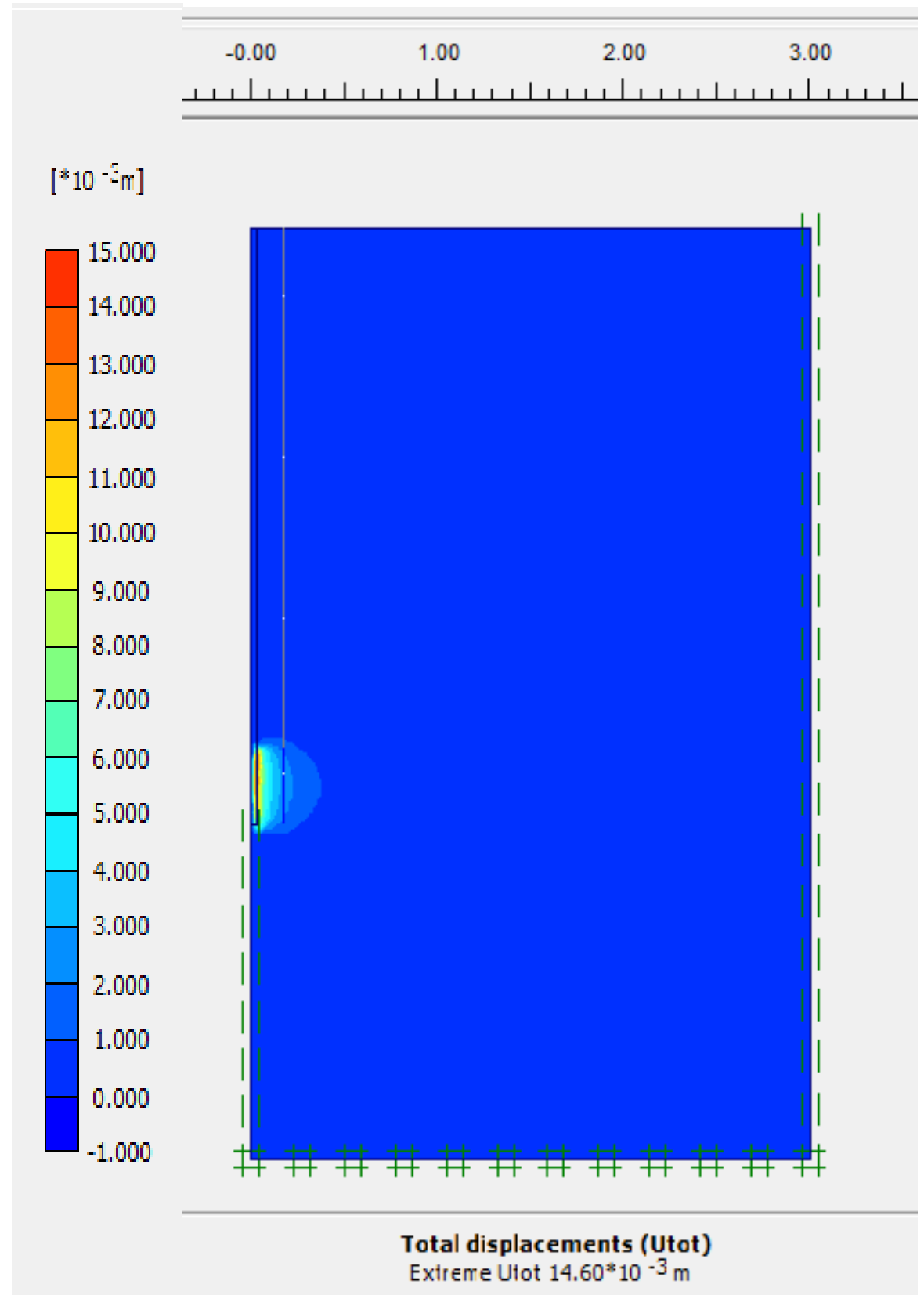

Figure 4.10 Horizontal displacement diagram 


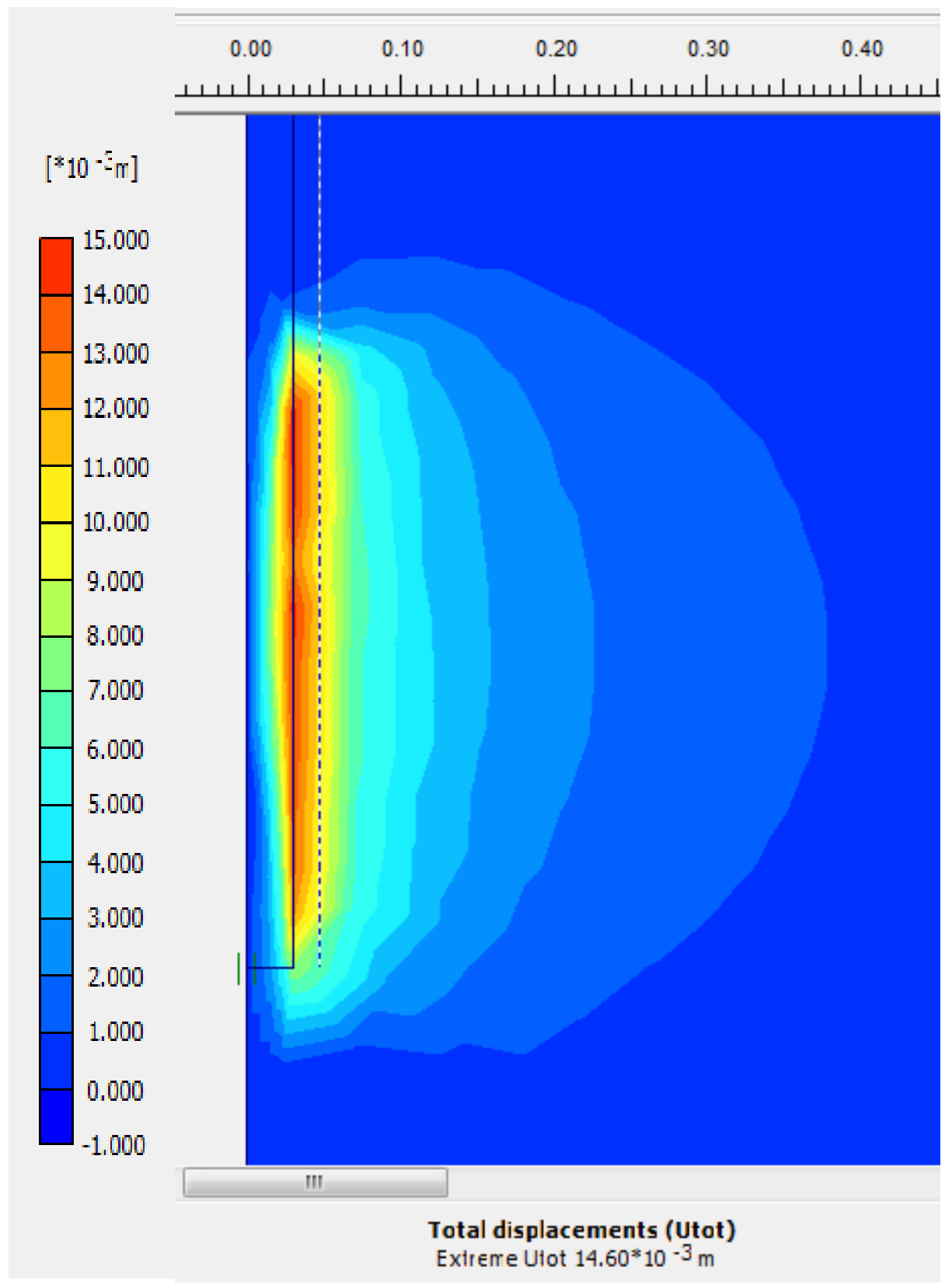

Figure 4.11 Zoomed view of the horizontal displacement diagram 


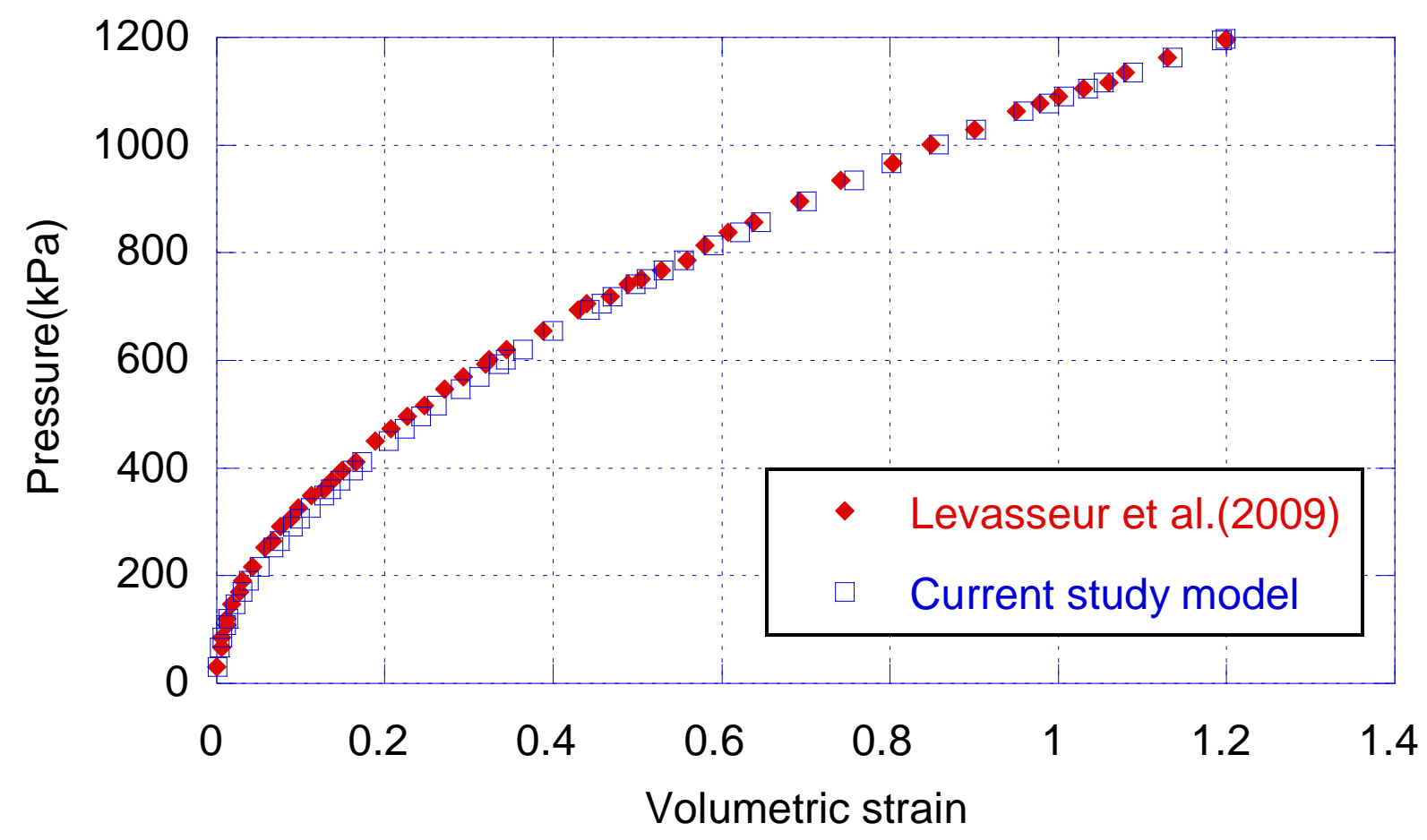

Figure 4.12 Pressure (p) vs volumetric strain $\left(\frac{\Delta v}{V}\right)$ curves for verification of the model

\subsection{SENSITIVITY STUDY}

This study is performed to investigate the influence of mesh coarseness, horizontal and vertical boundary conditions in the PMT model. Each case is elaborated below.

\subsubsection{MESH COARSENESS}

A mesh is a composition of finite elements that can be created in mesh mode in Plaxis 2D. In Plaxis, the mesh coarseness provides a significant influence on the calculation results. The model is implemented with five types of mesh coarseness such as very coarse, coarse, medium, fine and very fine mesh.

In order to evaluate the mesh influence in the Plaxis model, the Levasseur et al. (2009) is used as a bench mark problem to develop the horizontal displacements at the midpoint of the probe for different types of mesh coarseness with some applied pressures which are shown in Table 4.2. 
The difference in the horizontal displacement is about 1.27 times higher when the mesh changes from "very course" into "very fine". It shows that the very fine mesh gives more accurate results compare to other mesh coarseness, but it consumes more time during the simulation process. Due to that, fine mesh coarseness is adopted in this study. Mean time the differences between very fine to fine mesh coarseness is very small, nearly $0.85 \%$ different from very fine to fine.

Table 4.2 Comparison of horizontal displacement related to mesh coarseness

\begin{tabular}{|c|c|c|c|c|c|}
\hline \multirow{2}{*}{$\begin{array}{c}\text { Pressure } \\
(\mathrm{kPa})\end{array}$} & \multicolumn{5}{|c|}{ Horizontal displacement $\times 10^{-3}(\mathrm{~m})$ for mesh coarseness } \\
\cline { 2 - 6 } & Very fine & Fine & Medium & Course & Very course \\
\hline 500 & 3.53 & 3.50 & 3.49 & 3.37 & 2.78 \\
\hline 1000 & 10.98 & 10.90 & 10.85 & 10.83 & 8.78 \\
\hline 1500 & 21.90 & 21.41 & 20.67 & 20.78 & 16.81 \\
\hline 2000 & 37.18 & 35.76 & 33.87 & 33.63 & 26.42 \\
\hline
\end{tabular}

\subsubsection{HORIZONTAL BOUNDARY CONDITIONS}

The influence of horizontal distance from probe is investigated in this study. The right side boundary from the probe is not clearly stated in the literature. In order to evaluate the horizontal distance's influence in the Plaxis model, the Levasseur et al. (2009) is used as a bench mark problem to develop the pressure vs volumetric strain curves for different distances from the center of probe. The developed volumetric strain curves are shown in Figure 4.13 with the Levasseur et al. (2009) curve. The values of the volumetric strains with relation to the horizontal distances are shown in Table 4.3 with the Levasseur et al. (2009) value. Concluded from this study, the horizontal distances have no significant influence on the volumetric strain curves other than the $1 \mathrm{~m}$ distances. 


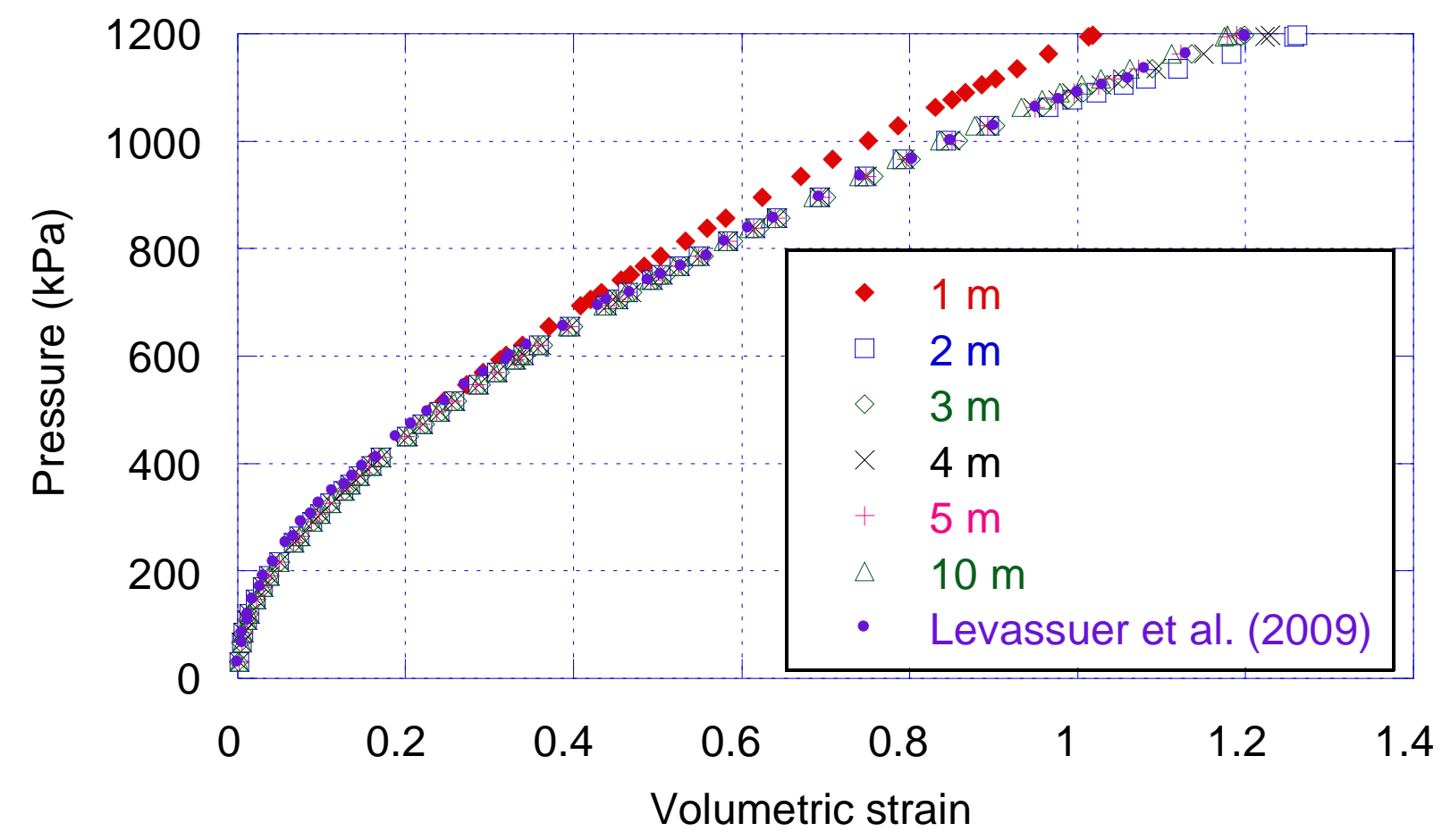

Figure 4.13 Pressure (p) vs volumetric strain $\left(\frac{\Delta v}{V}\right)$ curves for horizontal boundary conditions

Table 4.3 The values of volumetric strain related to horizontal distances

\begin{tabular}{|c|c|}
\hline Horizontal boundary condition $(\mathrm{m})$ & Volumetric strain $\left(\frac{\Delta v}{V}\right)$ \\
\hline 1 & 1.0183 \\
\hline 2 & 1.2620 \\
\hline 3 & 1.1943 \\
\hline 4 & 1.2290 \\
\hline 5 & 1.1894 \\
\hline 10 & 1.1785 \\
\hline Levassuer et al. (2009) & 1.2000 \\
\hline
\end{tabular}

\subsubsection{VERTICAL BOUNDARY CONDITIONS}

The influence of vertical distance below the bottom of the probe is investigated in this study. The vertical distance from bottom of the probe is not clearly stated in the literature. In order to 
evaluate the vertical distance's influence in the Plaxis model, the Levasseur et al. (2009) is used as a bench mark problem to develop the pressure vs volumetric strain curves for different distances from the bottom of the probe. The developed volumetric strain curves are shown in Figure 4.14 with the Levasseur et al. (2009) curve. The values of the volumetric strain with relation to the vertical boundary conditions are shown in Table 4.4 with the Levasseur et al. (2009) value. Concluded from this study, the vertical boundaries have no significant influence on the volumetric strain curves other than the $0 \mathrm{~m}$ distance.

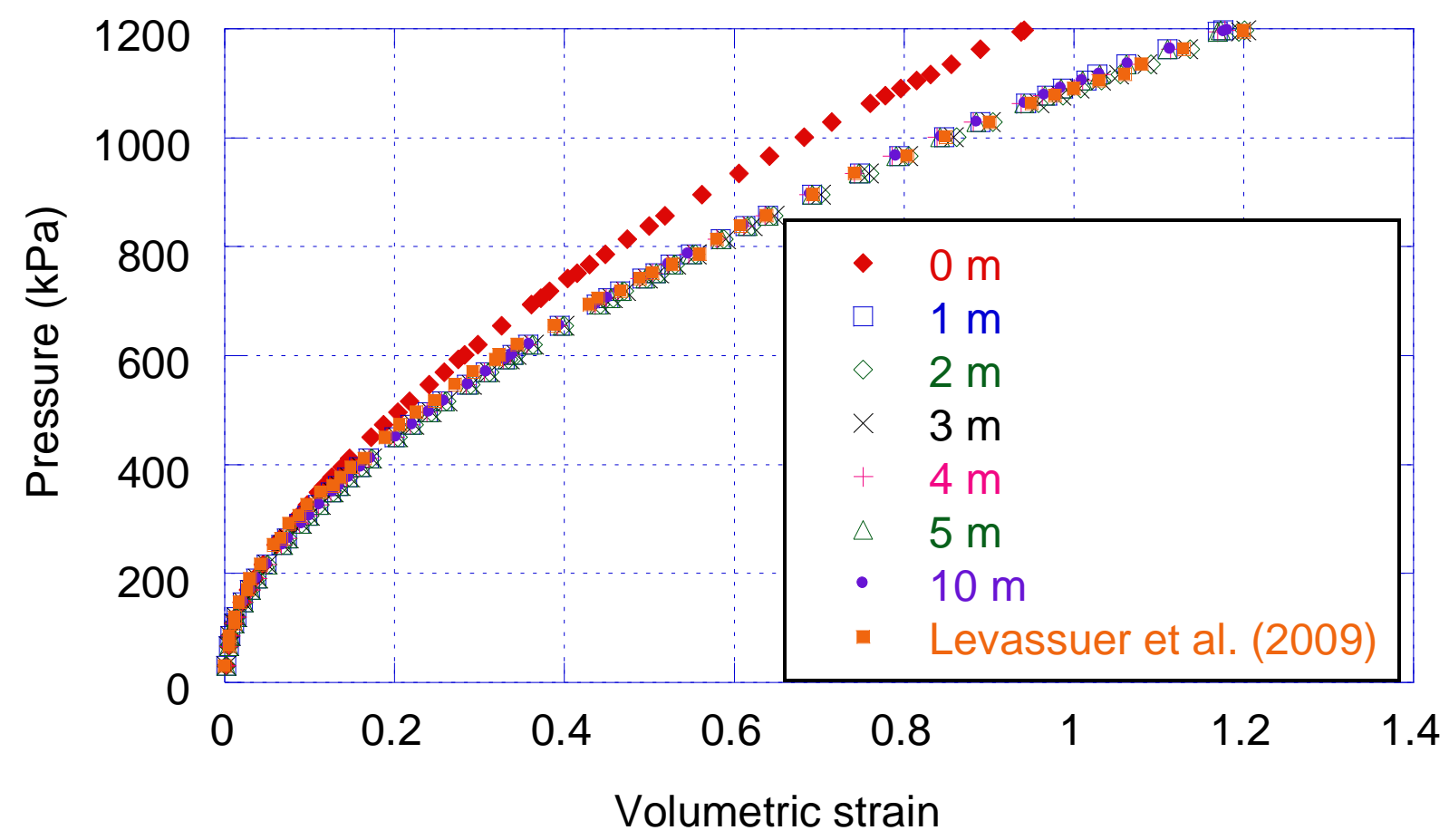

Figure 4.14 Pressure (p) vs volumetric strain $\left(\frac{\Delta v}{V}\right)$ curves for vertical boundary conditions

Table 4.4 The values of volumetric strain related to vertical boundary conditions

\begin{tabular}{|c|c|}
\hline $\begin{array}{c}\text { Vertical distance below the bottom of } \\
\text { the probe }(\mathrm{m})\end{array}$ & Volumetric strain $\left(\frac{\Delta v}{V}\right)$ \\
\hline 0 & 0.9414 \\
\hline 1 & 1.1756 \\
\hline 2 & 1.2013 \\
\hline 3 & 1.2033 \\
\hline
\end{tabular}




\begin{tabular}{|c|c|}
\hline 4 & 1.1776 \\
\hline 5 & 1.1737 \\
\hline 10 & 1.1815 \\
\hline Levassuer et al.(2009) & 1.2000 \\
\hline
\end{tabular}

\subsection{CASE STUDY AT MOUNT DENNIS STATION}

The main goal of this study is to back calculate the Young's modulus (E) of different types of glacial tills from PMT results using FEM. It was made from an extensive research on PMT results conducted in MD station in the ECLRT project in Toronto. It was analyzed from eleven (11) PMT results. The PM tests depth varies from $3.8 \mathrm{~m}$ to $35 \mathrm{~m}$. It was concluded, with TTC geotechnical standard (2014), most of the PMT results were from sand to sandy silt from $3 \mathrm{~m}$ to $21.3 \mathrm{~m}$ and clayey silt till deposited interbedded between silty clay in the depth which varies from $24.5 \mathrm{~m}$ to $35 \mathrm{~m}$. These types of materials are very heterogeneous and mixture of gravel, sand, silt and clay size particle in varying proportions ( $\mathrm{Ng}$ and Xue (2011)). The water table is observed a depth of $4.6 \mathrm{~m}$ below the ground surface. The processes of back calculating the $\mathrm{E}$ for different types of glacial tills are very complex and arduous task. Therefore in this study, back calculating $\mathrm{E}_{\mathrm{PMT}}$ for different types of glacial tills with knowing values of $\mathrm{E}$ with other soil parameters (c, $\varphi, \psi$ and $v$ ) are keeping constant. The $\mathrm{E}_{\mathrm{PMT}}$ values are computed from the quasilinear portion of the pressure vs radial strain curves. The $\mathrm{E}_{\mathrm{PMT}}$ is correlated with $\mathrm{E}$ value for various types of glacial tills. Then the linear correlation equations between $\mathrm{E}_{\mathrm{PMT}}$ and $\mathrm{E}$ are established for different types of glacial tills. The E values are predicted to the field measured $E_{\mathrm{PMT}}$ using the established correlation equations. The predicted $\mathrm{E}$ values are used as an input values in the simulation and again the $\mathrm{E}_{\mathrm{PMT}}$ values are calculated from the quasi-linear portion of the pressure vs radial strain curves. The calculated $\mathrm{E}_{\mathrm{PMT}}$ values have good agreement with field measured $\mathrm{E}_{\mathrm{PMT}}$. The Menard " $\alpha$ ” factors are developed for various types of glacial tills. 


\subsubsection{FINITE ELEMENT ANALYSES}

The FEM model geometry is created according to soil profile in the MD Station borehole number 101C3. The borehole report and PMT results are attached in Appendix 4.1 and 4.2 respectively. The soil profile has many layers which are shown in Figure 4.15. The width(x axis) and depth (y axis) of the soil profiles are pre-defined in the model tab on the project properties window. The limit of the soil contour is defined as the $x_{\min }=0, x_{\max }=40 \mathrm{~m}$ and $y_{\min }=-40 \mathrm{~m}$, $\mathrm{y}_{\max }=0$. The top boundary of the soil layer is at $\mathrm{y}=0$ at grade level and the bottom boundary of the soil layer is $\mathrm{y}=-40 \mathrm{~m}$ at bed rock. Once the soil layers are drawn, the soil properties can be assigned according to values shown in Table 4.5. These parameters are grasped from ECLRT geoengineering factual data reports for different type's glacial tills. (cohesionless glacial tills such as sand and sandy silt, cohesive glacial tills such as silty clay and clayey silt till). In addition, a small amount of cohesion $(\mathrm{c}=0.1 \mathrm{kPa})$ is assigned for sand to prevent soil failure upon unloading, which the soil may experience near the borehole wall during drilling or preboring (Sedran et al. (2013)). A small value of cohesion (c) is adopted to avoid complication while performing the simulation (Plaxis (2012)). 
Table 4.5 Summary of soil parameters used in the FEM analysis

\begin{tabular}{|c|c|c|c|c|c|c|c|c|}
\hline Soil type & Depth & \multicolumn{7}{|c|}{ Plaxis 2D (MCM ) } \\
\cline { 3 - 9 } & $(\mathrm{m})$ & $\begin{array}{c}\gamma_{\text {Unsaturated }} \\
\left(\mathrm{kg} / \mathrm{m}^{3}\right)\end{array}$ & $\begin{array}{c}\gamma_{\text {Saturated }} \\
\left(\mathrm{kg} / \mathrm{m}^{3}\right)\end{array}$ & $\begin{array}{c}\mathrm{c} \\
\left(\mathrm{kN} / \mathrm{m}^{2}\right)\end{array}$ & $\begin{array}{c}\varphi \\
\left({ }^{0}\right)\end{array}$ & $\begin{array}{c}\Psi \\
\left({ }^{0}\right)\end{array}$ & $v$ & $\begin{array}{c}\text { Initial E } \\
\left(\mathrm{kN} / \mathrm{m}^{2}\right)\end{array}$ \\
\hline Fill & 0.41 & 14 & 16 & 15 & 0 & 0 & 0.25 & 10000 \\
\hline Sand & 3.8 & 17 & 21 & 0.1 & 41 & 11 & 0.33 & 25000 \\
\hline Sand & 6.0 & 19 & 22 & 0.1 & 42 & 12 & 0.33 & 25000 \\
\hline Sandy silt & 9.4 & 17 & 20.4 & 10 & 43 & 13 & 0.33 & 25000 \\
\hline Sandy silt & 13.9 & 17 & 20.4 & 10 & 39 & 9 & 0.33 & 25000 \\
\hline Sandy silt & 15.2 & 17 & 20.4 & 10 & 42.5 & 12.5 & 0.33 & 25000 \\
\hline Sandy silt & 18.3 & 17 & 20.4 & 10 & 39 & 9 & 0.33 & 25000 \\
\hline Sand & 21.3 & 19 & 22 & 0.1 & 45 & 15 & 0.33 & 25000 \\
\hline Silty clay & 24.5 & 17 & 20.4 & 100 & 32 & 2 & 0.33 & 20000 \\
\hline Clayey silt till & 27.3 & 17 & 21.8 & 50 & 35 & 5 & 0.33 & 20000 \\
\hline Clayey silt till & 30.4 & 17 & 22.1 & 50 & 35 & 5 & 0.33 & 20000 \\
\hline Silty clay & 35.0 & 17 & 20.4 & 100 & 32 & 2 & 0.33 & 20000 \\
\hline Bentonite & 12 & 14 & 10 & 0 & 0 & 0.10 & 6000 \\
\hline
\end{tabular}

The soil is modelled with the M-C model since its limited number of input parameters and its popularity in the practice. Due to the granular nature of the soils such as sand and sandy silt, all calculations are made in drained condition. For the silty clay and clayey silt till soils, all calculations are made in undrained (A) condition according to Plaxis 2D material model (2012). The analysis is performed as an axisymmetric and the mesh elements are 15 nods triangles. The standard fixity boundary condition is applied for the soil profile. As a result Plaxis will automatically generate full fixity at the base of the geometry and roller boundaries at the vertical sides $\left(\mathrm{U}_{\mathrm{x}}=0 ; \mathrm{U}_{\mathrm{y}}=\right.$ free $)$. The soil is free on the vertical walls of drilling and vertical movement is possible on the two vertical borders of the soil profile (Houari and Abdeldjalil (2015)). The boundary conditions of the MD Station soil profile are shown in Figure 4.15.

The PMT geometry is discretized using a 2D axisymmetric configuration for PMT probe with a length $(460 \mathrm{~mm})$-to-diameter $(76 \mathrm{~mm})$ ratio of 6.05 , typical of the Roctest NX-sized PMT probe. 
The recommended length to diameter ratio is 6 or more (Briaud (1992)). Positive interface is introduced on the probe and vertical surface of the PMT borehole. A "Type B" loading is applied on the probe as shown in Figure 4.15 at the test depth during the simulation stages. This loading is applied radially on a length equal to the length of the probe, in downhole (Husein (2001)). The loading condition is shown in Figure 4.15.

Once the geometry modelling process is complete, calculations are proceeded which consists of the generation of meshes and definition of the construction stages. The defined geometry has to be divided into finite elements in order to perform a FEM calculation. A mesh is a composition of finite elements that can be created in mesh mode in Plaxis 2D. In Plaxis, the mesh coarseness provides a significant influence on the calculation results. The model is implemented with five types of mesh coarseness such as very coarse, coarse, medium, fine and very fine mesh.

At the end of the analysis is performed in the section 4.5.1, the fine mesh density is selected due to its accuracy and speed of calculations. A fine mesh is used for the Plaxis 2D models analysis (Khanal (2013)). In addition to that extra geometry lines are created around the probe to locally generate a finer mesh. A typical FE mesh of MD Station is shown in Figure 4.16.

The PMT is simulated in the following three stages.

(i) Generation of in-situ initial stress condition by imposed by $\mathrm{K}_{0}$ value as shown in Figure 4.17.

(ii) Borehole drilling and filled the borehole with mud(bentonite)

(iii) Applied pressure at the probe borehole interface incrementally.

During the above procedures the probe's volume increases due to the pressure applied to the probe and therefore the soil around it will deform. Then the horizontal displacement is recorded from Plaxis output to calculate the radial strain. The pressure vs radial strain curve is plotted for each Young's modulus (E) in each depth to calculate the PMT modulus ( $\mathrm{E}_{\mathrm{PMT}}$ ). In this calculation a special attention is paid to that the two slopes of the experimental and numerical curves in the elastic phase should be similar. 


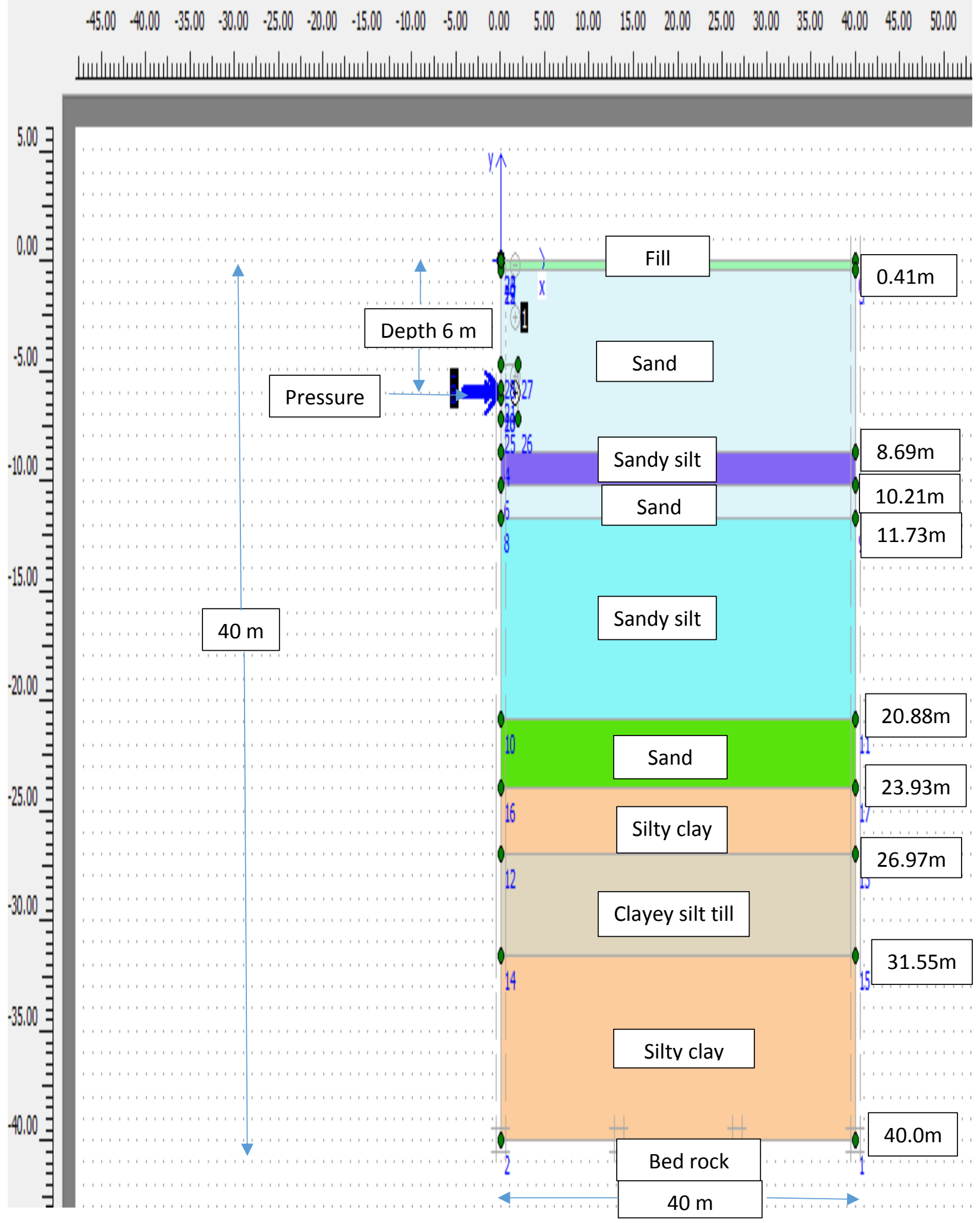

Fihure 4.15 10 Soil profile at Mount Dennis Station according to borehole MD101-PMT and test @ 6.0m depth 


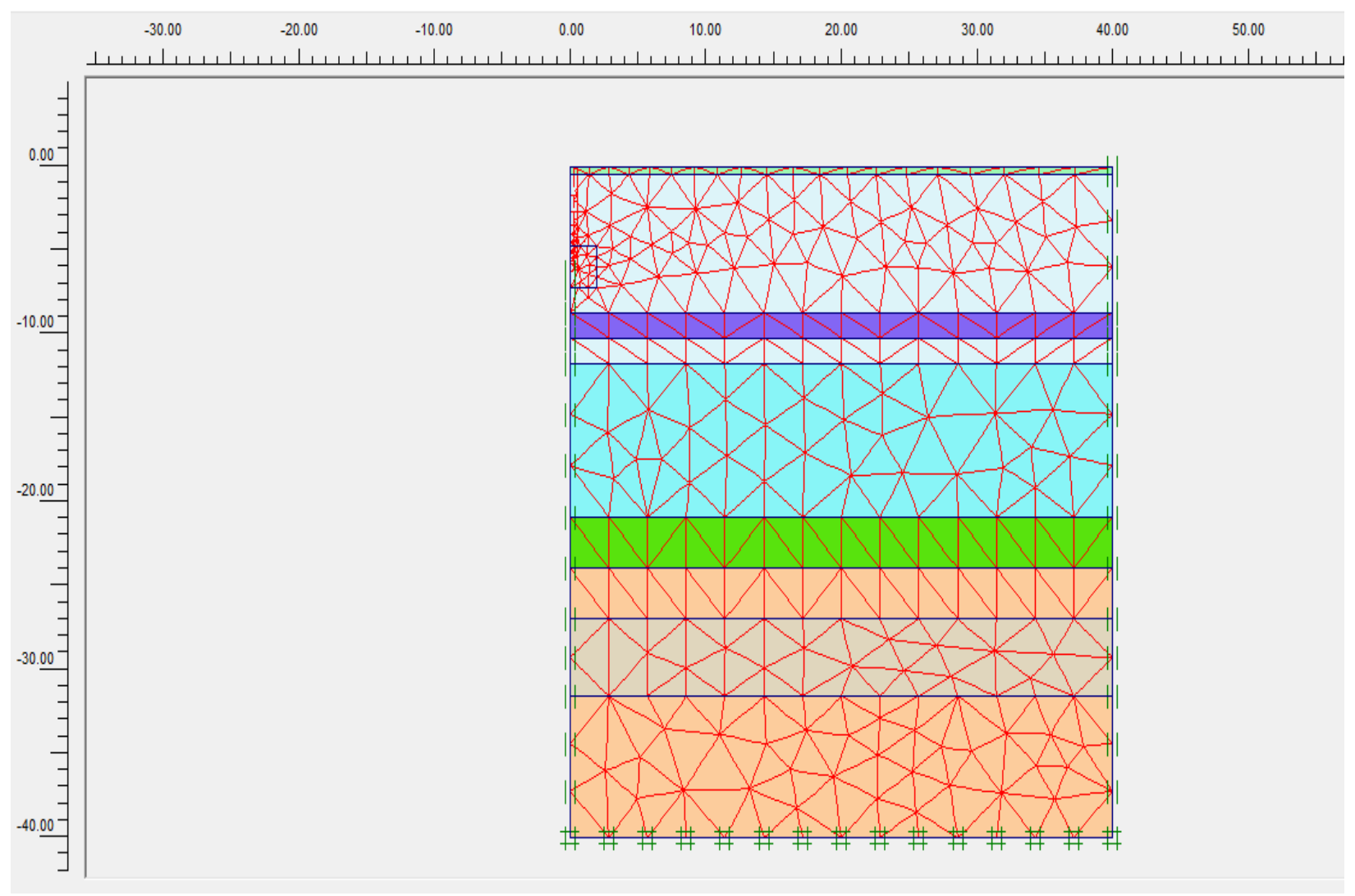

Fihure 4.16 Typical FE mesh for numerical simulation at MD Station

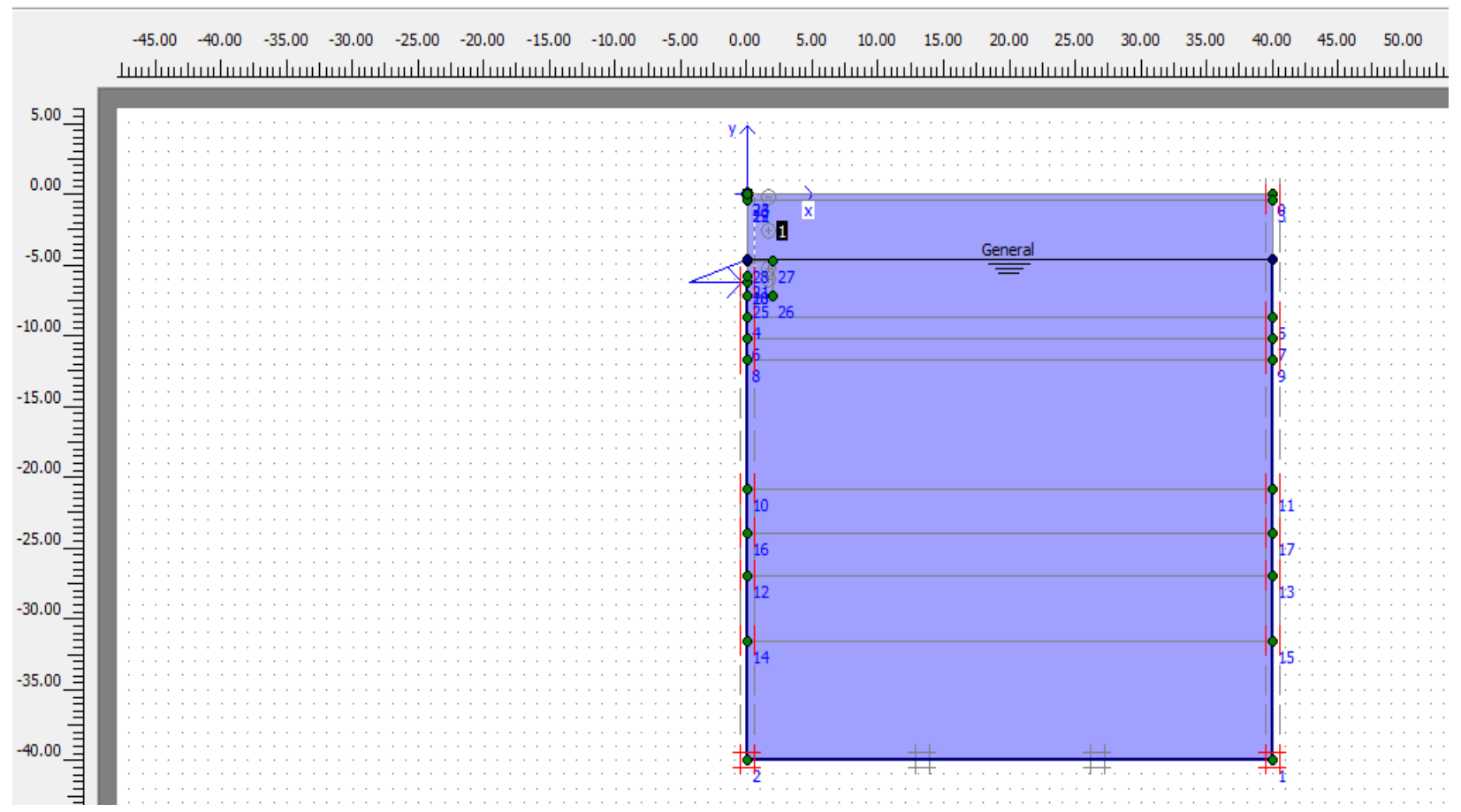

Figure 4.17 Water table diagram for soil profile at MD Station @ test depth 6m after generate the in-situ initial stress condition. 


\subsubsection{D FINITE ELEMENT RESULTS AND ANALYSIS}

The numerical simulation is performed at different depths from $3.8 \mathrm{~m}$ to $35 \mathrm{~m}$ according to MD Station borehole MD101-PMT. A range of simulations are completed for different values of Young's modulus in each depth. The pressures are applied on the probe incrementally during the simulation. The displacements are measured at the mid-point of the probe for each pressure increments. The results can be viewed in the output mode and the most notable results are the deformed mesh, total displacement, lateral (horizontal) displacement and cross section of the lateral displacement $(U x)$.

The typical deformed mesh with the total displacement diagram at $6 \mathrm{~m}$ depth is shown in Figure 4.18. The zoomed view of the deformed mesh diagram is shown in Figure 4.19. The $x$ direction (horizontal) displacement at the mid-point of the probe after FEM analysis is shown in Figure 4.20. The zoomed view of the horizontal displacement at the mid-point of the probe is shown in Figure 4.21. The horizontal displacement shaded diagram and the zoomed view of the shaded diagram are shown in Figure 4.22 and Figure 4.23 respectively. A typical cross section of horizontal displacement diagram is shown in Figure 4.24. The zoomed view of the cross section of horizontal displacement diagram is shown in Figure 4.25. 


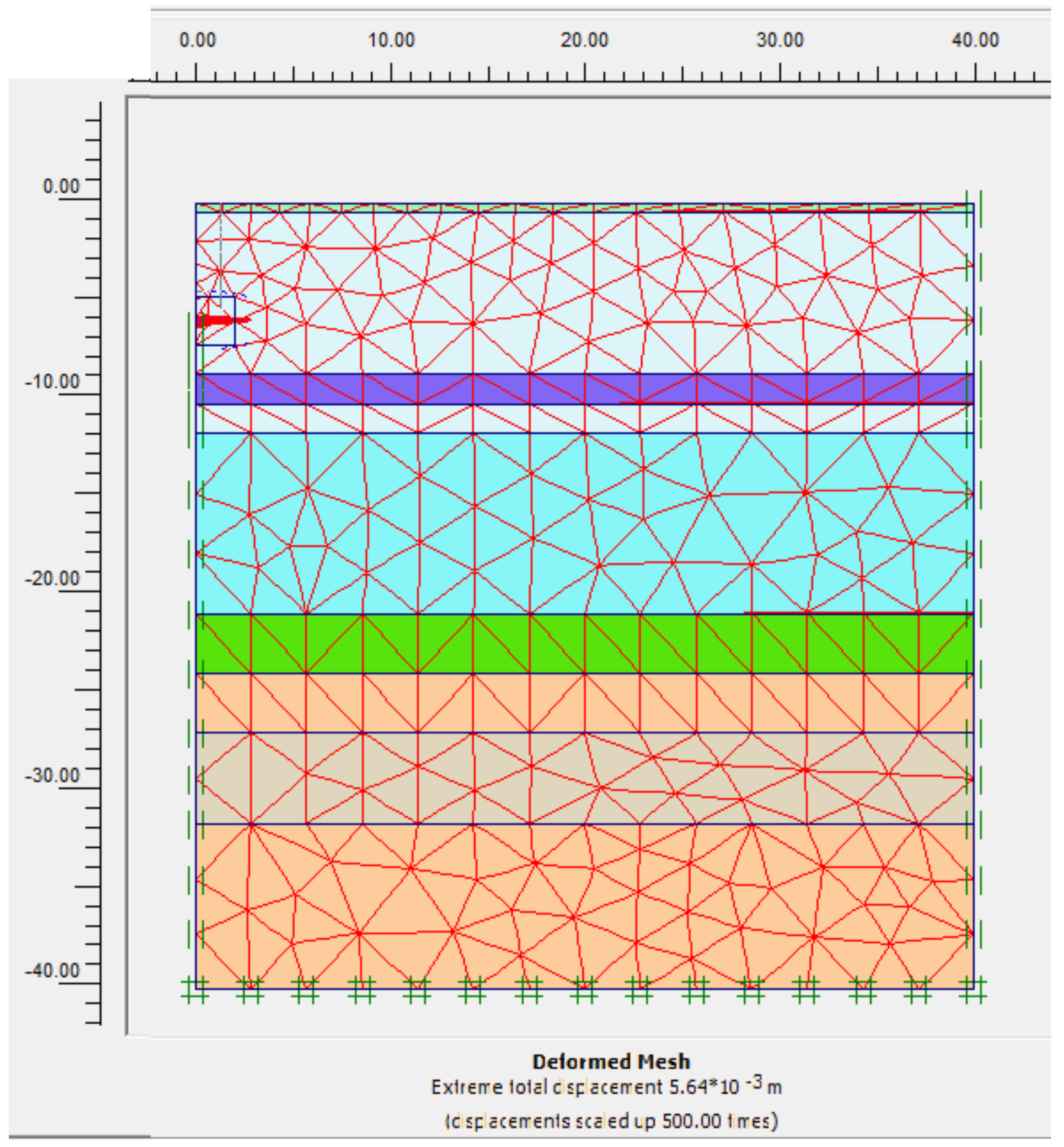

Figure 4.18 Typical deformed meshes @ $6.0 \mathrm{~m}$ depth at MD Station 


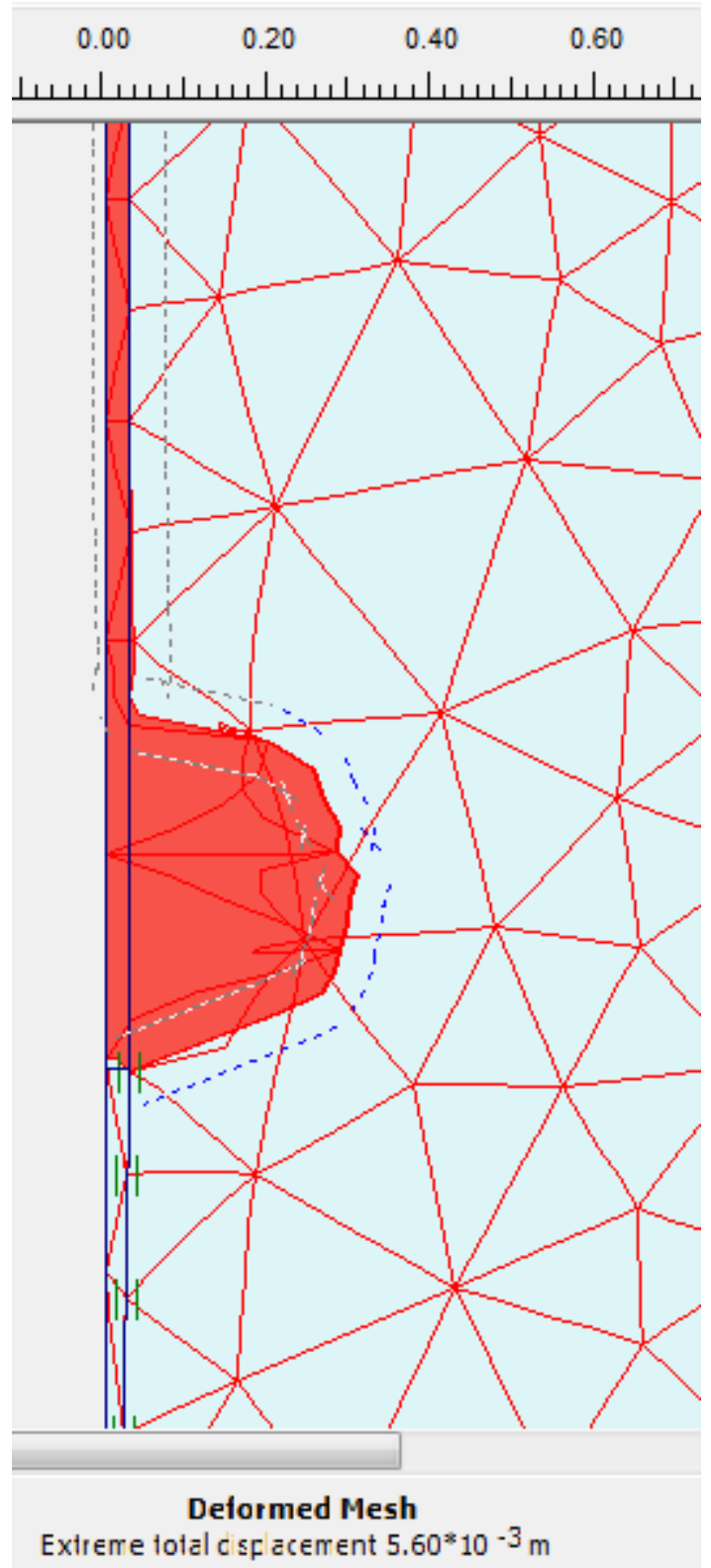

Figure 4.19 Zoomed views of the deformed meshes diagram@6.0 m depth at MD station 


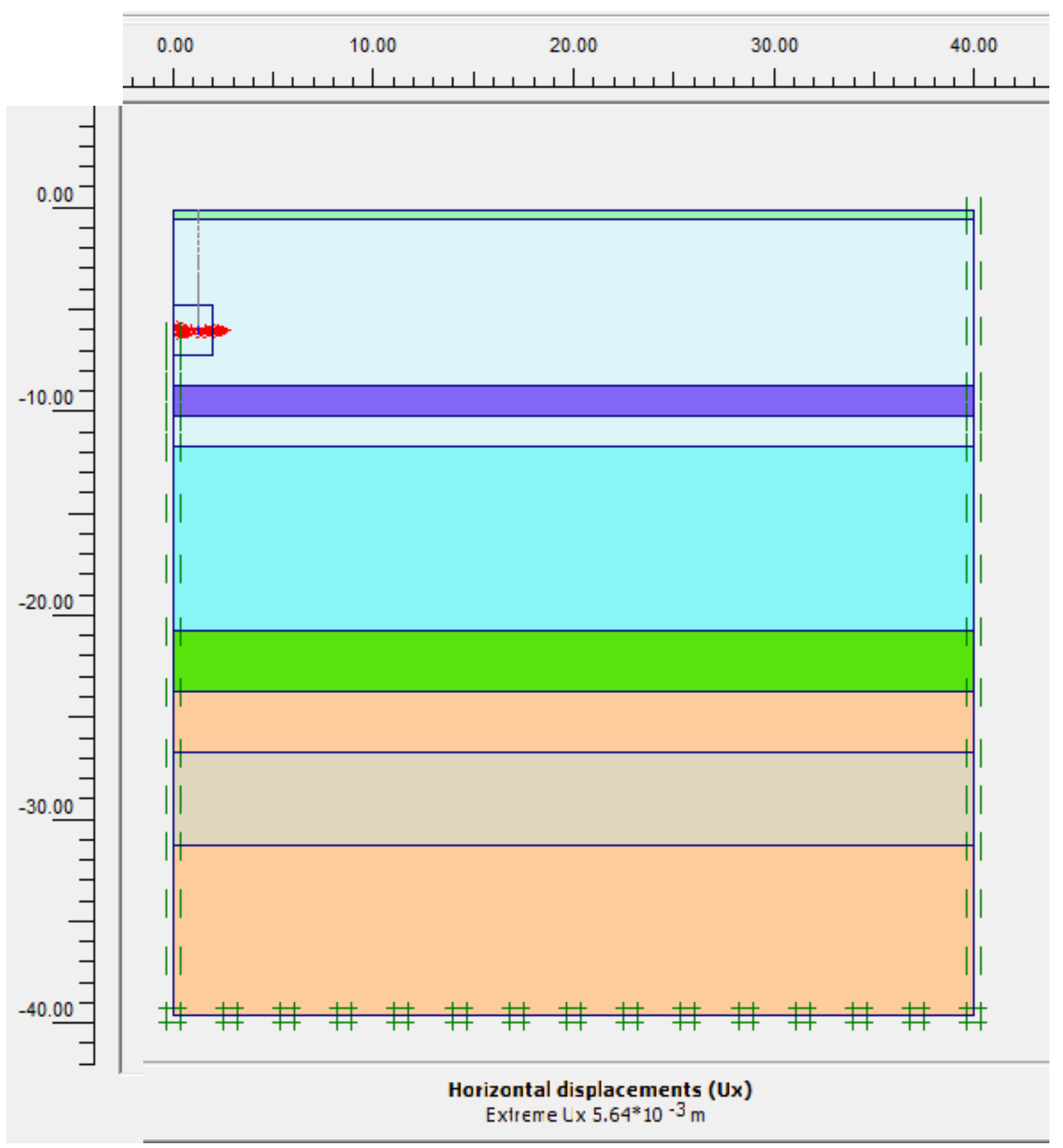

Figure 4.20 Typical horizontal displacement arrow diagram@6.0m depth at MD Station 


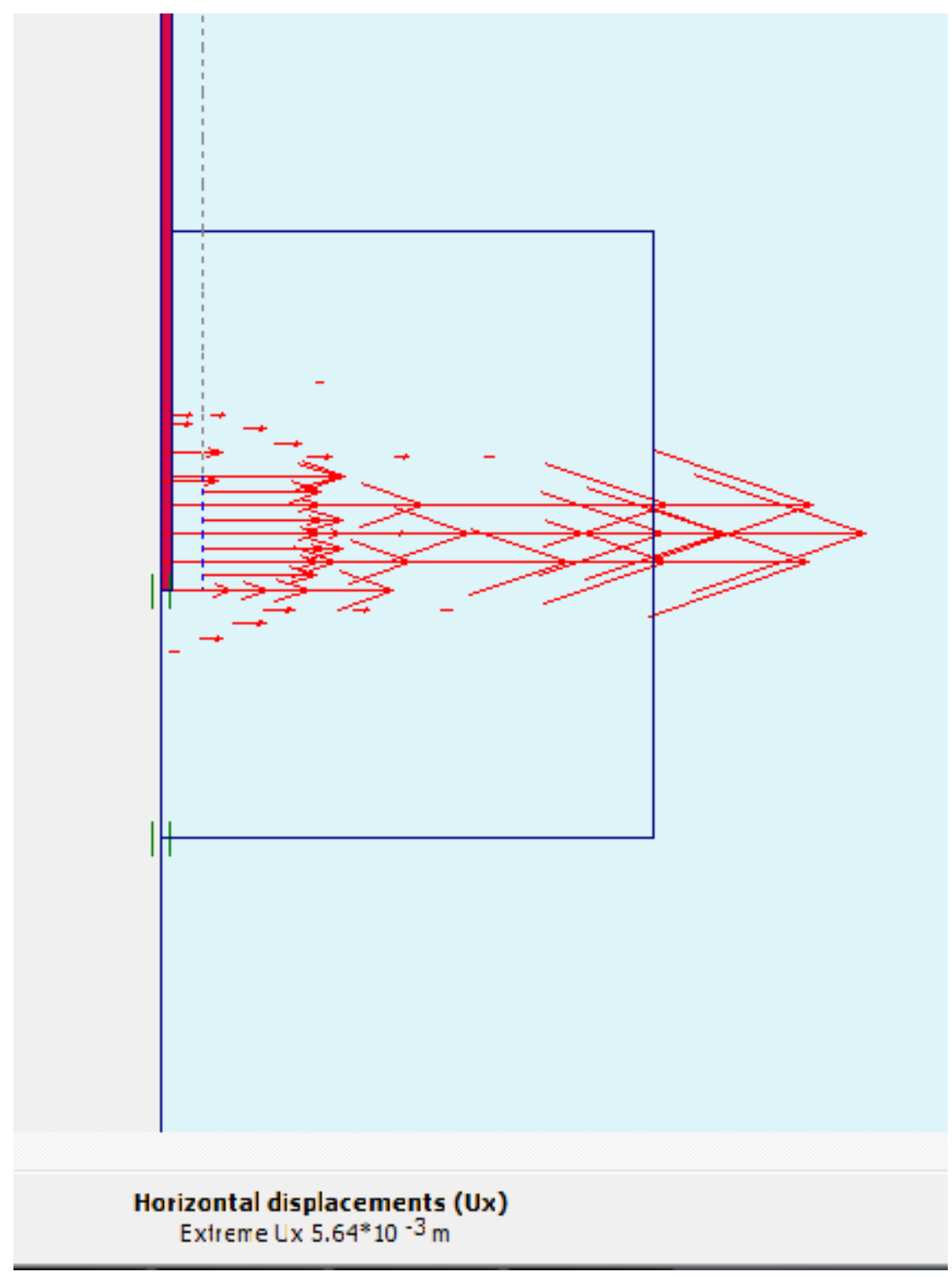

Figure 4.21 Zoomed view of the horizontal displacement arrow diagram @ 6.0m depth at MD Station 


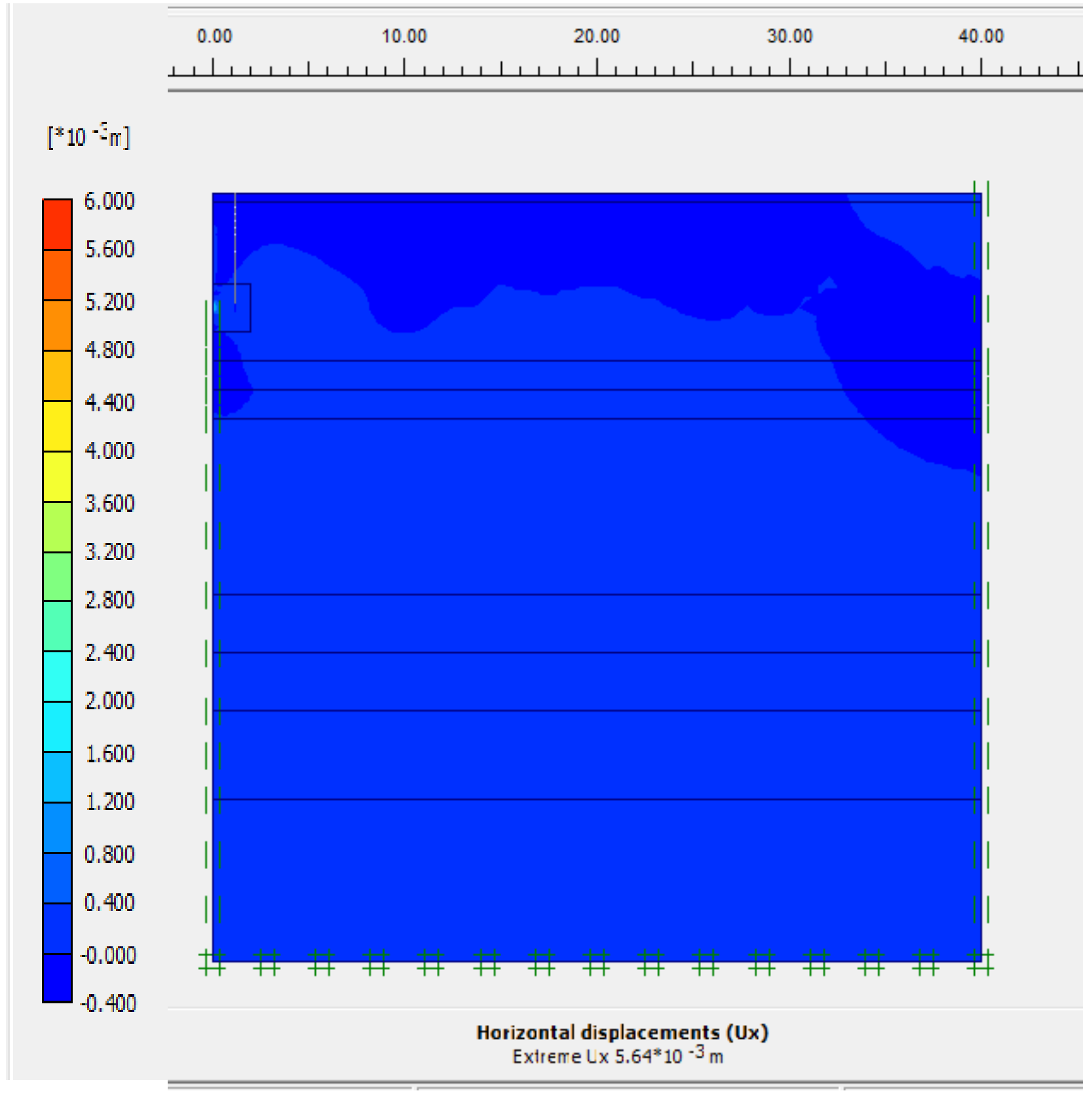

Figure 4.22 Typical horizontal displacement shaded diagram @6.0m depth at MD Station 


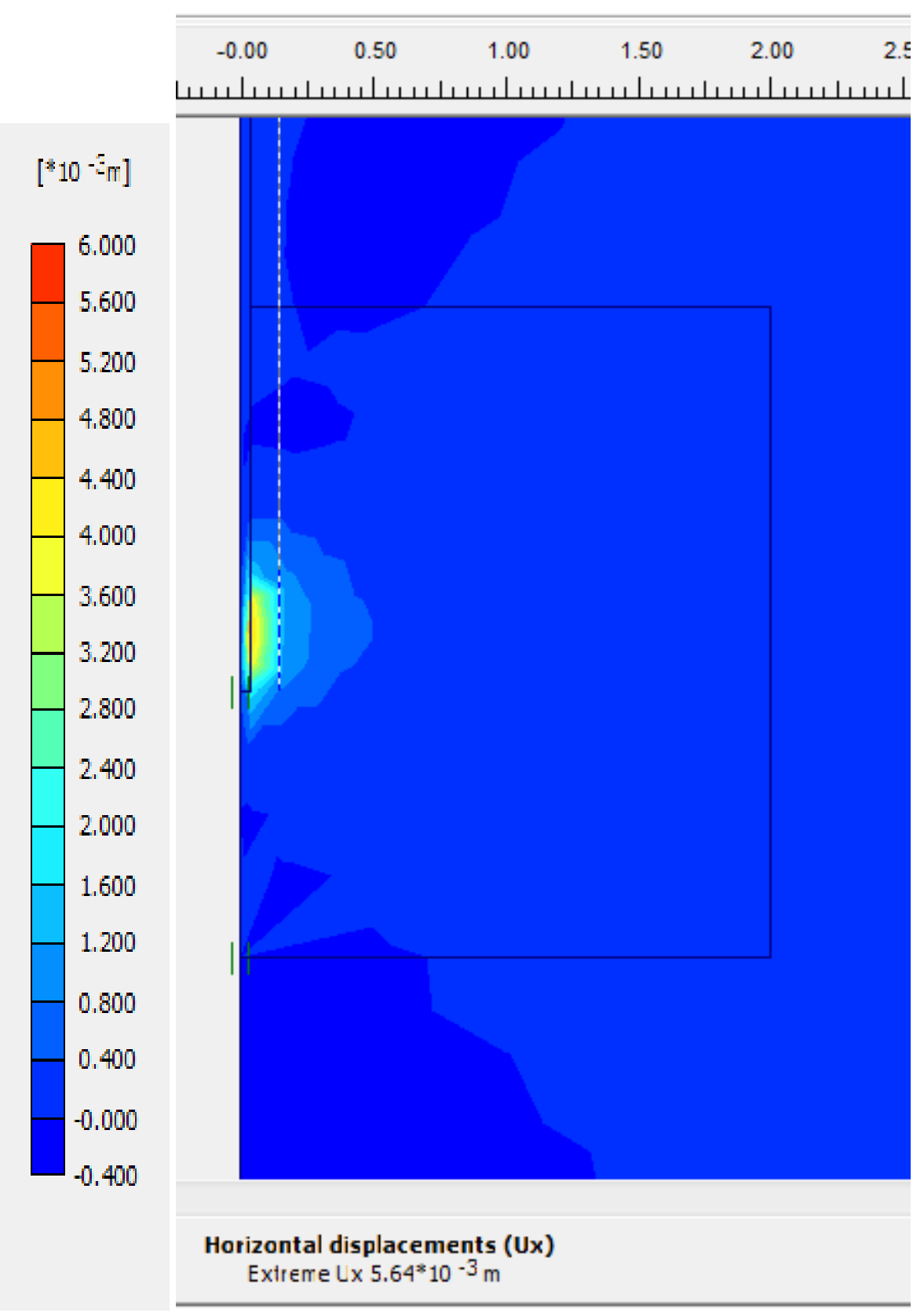

Figure 4.23 Zoomed view of horizontal displacement shaded diagram @ $6.0 \mathrm{~m}$ depth at MD Station 


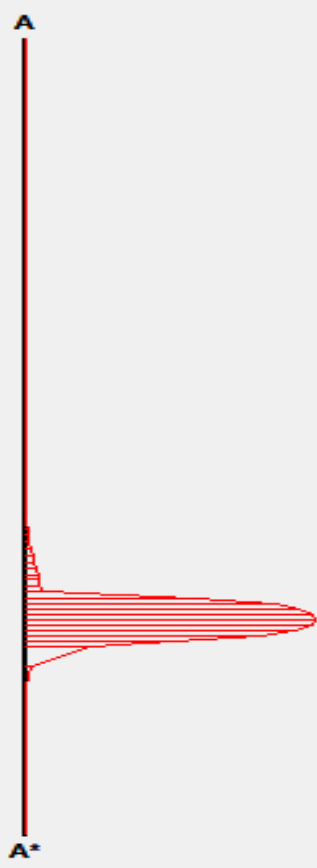

Figure 4.24 Typical horizontal displacement cross section@ 6.0 m depth at MD Station

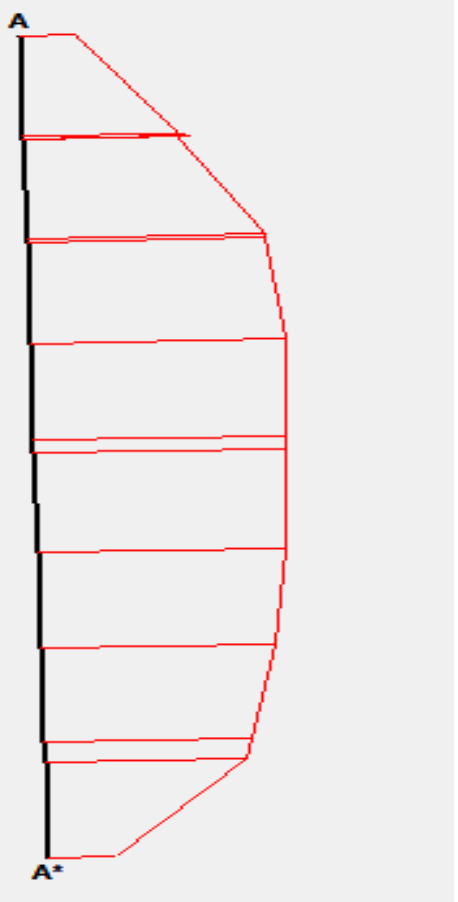

Figure 4.25 Zoomed view of horizontal displacement cross section (along the probe) @6.0 m depth at MD Station 


\subsubsection{COMPARISON OF PRESSURE VS RADIAL STRAIN CURVES FROM PMT AND PLAXIS}

It is instructive to compare the results of PMT with those obtained from our numerical results. Figure 4.26 shows the typical pressure vs radial strain graphs for field PMT measurement and simulated PMT curves at $6.0 \mathrm{~m}$ depth with different values of Young's modulus. It can be seen that the measured PMT curves and the numerical curves obtained using the proposed numerical model are more or less similar for each depth that was investigated. During the simulation, it is seen that the curves obtained from simulations are not best fit with the field curves. There should be a many reasons for that, those are listed below:

(i) The diameter of the probe has an impact on the quality of the test. That is a diameter of drilling bit should be equal to the diameter of the probe.

(ii) Rotation should be slow to minimize enlargement of borehole.

(iii) Mud circulation should be slow to minimize erosion.

(iv) Borehole walls left behind the bit may be disturbed.

(v) The Poisson's ratio was taken as 0.33 for whole soil profile but not at all. For saturated soils Poisson's ratio vary from 0.33 to 0.45 . The Menard PM modulus means Poisson's ratio is 0.33 . In this project whole calculations were performed for Poisson's ratio 0.33 .

(vi) The soil mass was assumed to be continuum, uniform and isotropic.

(vii) Special training is required for drillers to prepare a good PMT borehole as drilling for PMT.

In addition to the reasons above the field curve initially starts horizontally then increased, but numerical simulation curves increased vertically. The reason is that in the field PMT the volume is increased then the pressure was measured, but in the simulation the pressure is applied then the deformation is measured. Due to that, in the initial the field PMT curve is going horizontally until it touches the borehole wall and after it has touched the borehole wall, it will increase. But in the simulation, the pressure vs radial curve is going vertically until it touches the borehole wall and after it has touched the wall, it will increase as well. 
For each simulation, back-calculation is done for the values of $\mathrm{E}_{\mathrm{PMT}}$ by using Equation 2.8 in the section 2.2.2.3, in Chapter 2, for each Young modulus and tabulated in Table 4.6. In this calculation a special attention is paid to that the two slopes of the experimental and numerical curves in the elastic phase should be similar. The portion of the curves that are used for the calculation is shown by an arrow in Figure 4.26. Then the calculated PMT modulus (E $\mathrm{E}_{\mathrm{PMT}}$ ) vs Young modulus (E) graphs that are plotted for various depths are shown in Figure 4.27 for cohesionless glacial tills and Figure 4.28 for cohesive glacial tills respectively. The correlation equations between the modulus above with their coefficients are also tabulated in Table 4.6. The Menard " $\alpha$ " factors are calculated at each depth for different types of glacial tills at MD Station are also shown in Table 4.6. This study shows a very good agreement with Menard " $\alpha$ ” factors.

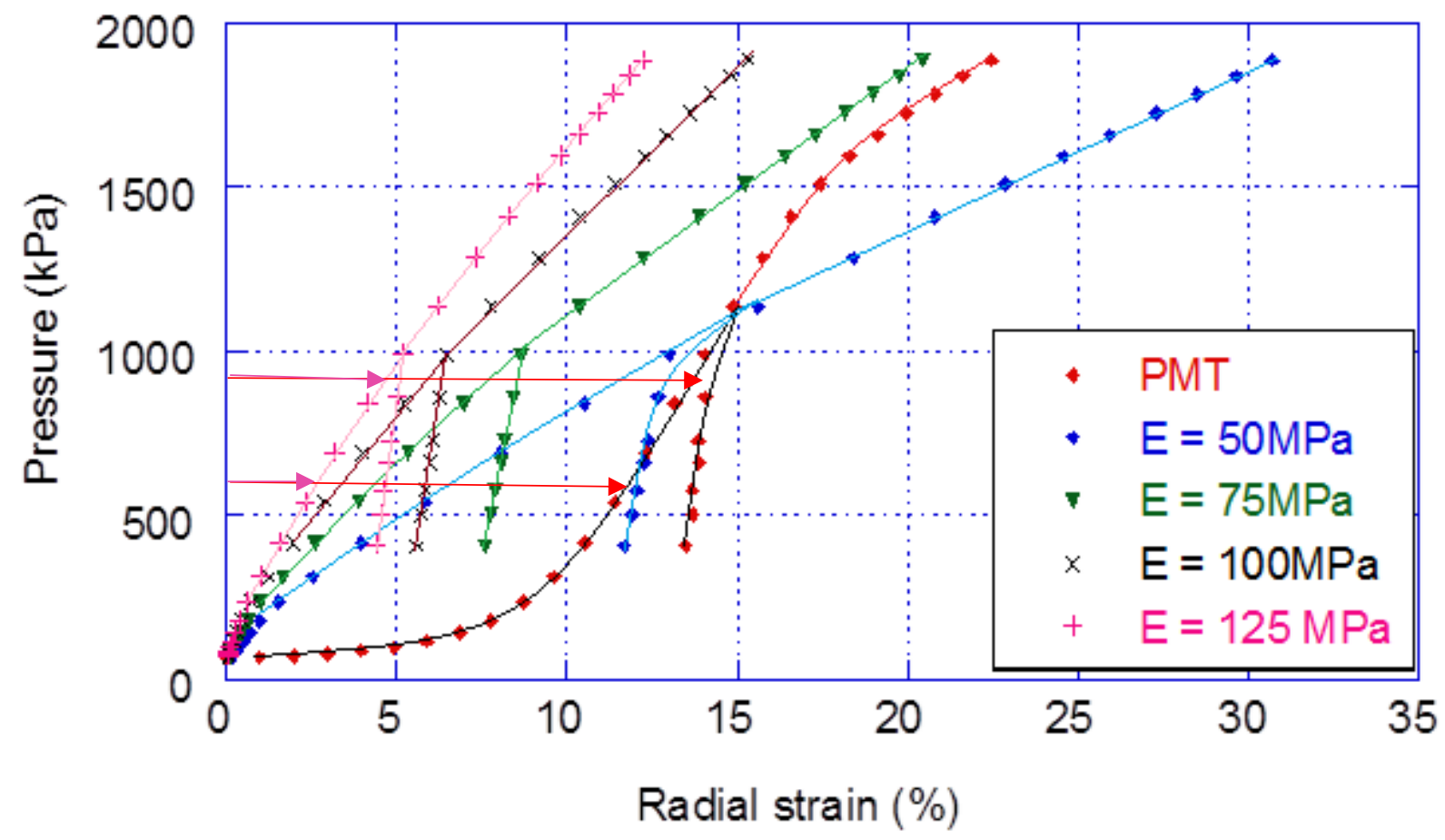

Figure 4.26 Pressure vs radial strain graphs at 6m depth for MD Station 
Table 4.6 Linear correlation equations for glacial tills at MD Station

\begin{tabular}{|c|c|c|c|c|c|c|}
\hline $\begin{array}{l}\text { Depth } \\
\text { (m) }\end{array}$ & Soil type & $\begin{array}{l}\text { Young's } \\
\text { modulus (E) } \\
(\mathrm{MPa})\end{array}$ & $\begin{array}{l}\text { PMT modulus } \\
\left(\mathrm{E}_{\mathrm{PMT}}\right)(\mathrm{Mpa})\end{array}$ & $\begin{array}{l}\text { Correlation } \\
\text { equation }\end{array}$ & $\begin{array}{c}\text { Correlation } \\
\text { coefficient } \\
\left(\mathrm{R}^{2}\right)\end{array}$ & $\alpha=\frac{E_{P M T}}{E}$ \\
\hline \multirow[t]{6}{*}{3.8} & \multirow[t]{6}{*}{ Sand } & 25 & 7.95 & \multirow[t]{6}{*}{$\mathrm{E}_{\mathrm{PMT}}=0.34 \mathrm{E}$} & \multirow[t]{6}{*}{1.0} & 0.32 \\
\hline & & 50 & 18.77 & & & 0.38 \\
\hline & & 75 & 25.91 & & & 0.35 \\
\hline & & 100 & 34.68 & & & 0.35 \\
\hline & & 125 & 43.26 & & & 0.35 \\
\hline & & 150 & 50.24 & & & 0.34 \\
\hline \multirow[t]{6}{*}{6} & \multirow[t]{6}{*}{ Sand } & 25 & 4 & \multirow[t]{6}{*}{$\mathrm{E}_{\mathrm{PMT}}=0.15 \mathrm{E}$} & \multirow[t]{6}{*}{1.0} & 0.16 \\
\hline & & 50 & 8 & & & 0.16 \\
\hline & & 75 & 12 & & & 0.16 \\
\hline & & 100 & 15 & & & 0.15 \\
\hline & & 125 & 19 & & & 0.15 \\
\hline & & 150 & 22 & & & 0.15 \\
\hline \multirow[t]{6}{*}{9.4} & \multirow{6}{*}{$\begin{array}{l}\text { Sandy } \\
\text { silt }\end{array}$} & 25 & 7.4 & \multirow[t]{6}{*}{$\mathrm{E}_{\mathrm{PMT}}=0.28 \mathrm{E}$} & \multirow[t]{6}{*}{1.0} & 0.30 \\
\hline & & 50 & 14.4 & & & 0.29 \\
\hline & & 75 & 21.4 & & & 0.29 \\
\hline & & 100 & 28.4 & & & 0.28 \\
\hline & & 125 & 35.2 & & & 0.28 \\
\hline & & 150 & 42.2 & & & 0.28 \\
\hline \multirow[t]{6}{*}{13.9} & \multirow{6}{*}{$\begin{array}{l}\text { Sandy } \\
\text { silt }\end{array}$} & 25 & 9.44 & \multirow[t]{6}{*}{$\mathrm{E}_{\mathrm{PMT}}=0.35 \mathrm{E}$} & \multirow[t]{6}{*}{1.0} & 0.38 \\
\hline & & 50 & 19.32 & & & 0.39 \\
\hline & & 75 & 29.43 & & & 0.39 \\
\hline & & 100 & 36.18 & & & 0.36 \\
\hline & & 125 & 43.16 & & & 0.35 \\
\hline & & 150 & 50.85 & & & 0.34 \\
\hline \multirow[t]{2}{*}{15.2} & \multirow{2}{*}{$\begin{array}{l}\text { Sandy } \\
\text { silt }\end{array}$} & 25 & 8.22 & \multirow[t]{2}{*}{$\mathrm{E}_{\mathrm{PMT}}=0.31 \mathrm{E}$} & \multirow[t]{2}{*}{1.0} & 0.33 \\
\hline & & 50 & 15.84 & & & 0.32 \\
\hline
\end{tabular}




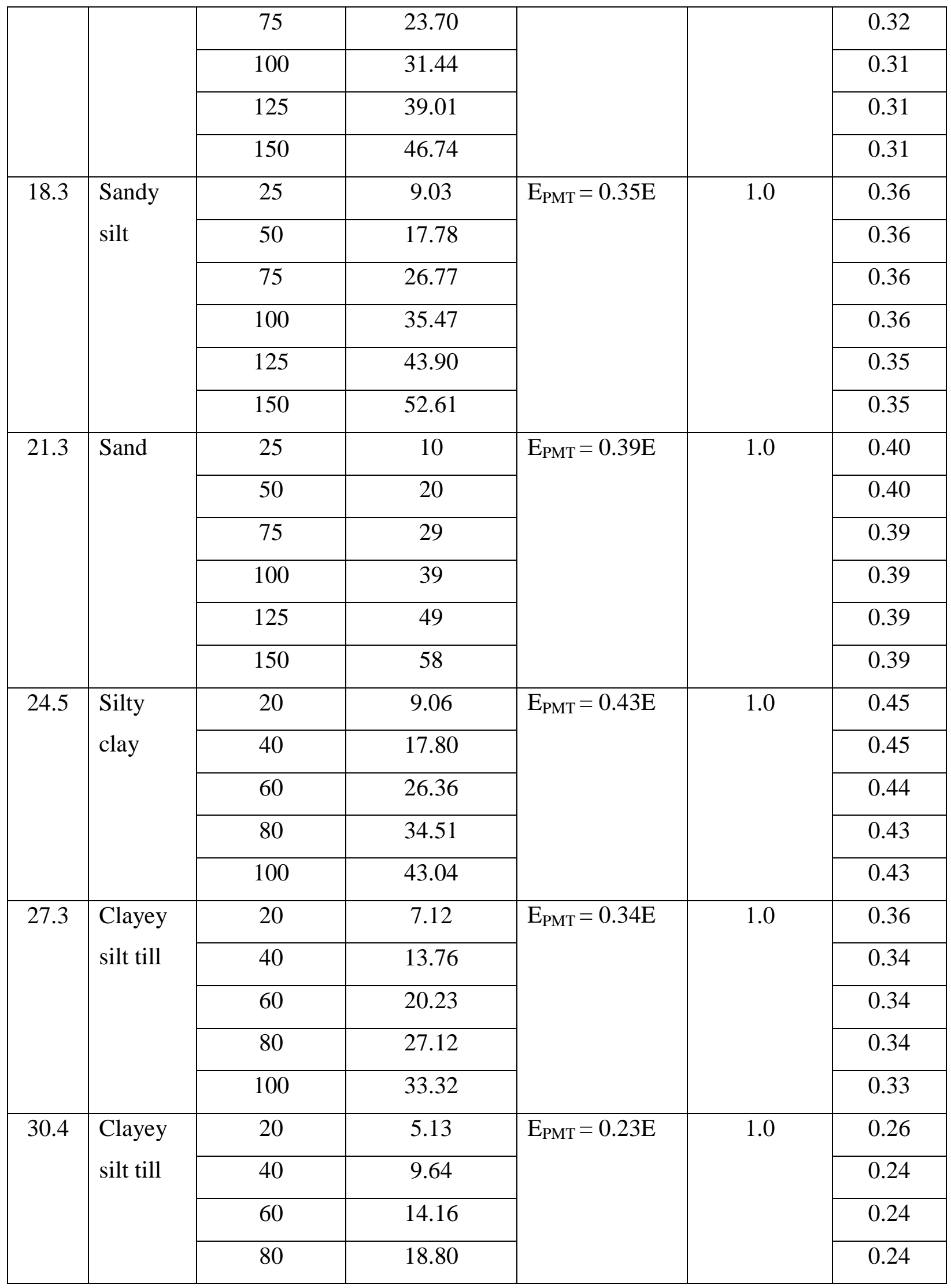




\begin{tabular}{|c|c|c|c|c|c|c|}
\hline & & 100 & 23.10 & & & 0.23 \\
\hline \multirow[t]{5}{*}{35} & \multirow{5}{*}{$\begin{array}{l}\text { Silty } \\
\text { clay }\end{array}$} & 20 & 8.93 & \multirow[t]{5}{*}{$\mathrm{E}_{\mathrm{PMT}}=0.43 \mathrm{E}$} & \multirow[t]{5}{*}{1.0} & 0.45 \\
\hline & & 40 & 17.30 & & & 0.43 \\
\hline & & 60 & 25.76 & & & 0.43 \\
\hline & & 80 & 34.21 & & & 0.43 \\
\hline & & 100 & 42.70 & & & 0.43 \\
\hline
\end{tabular}

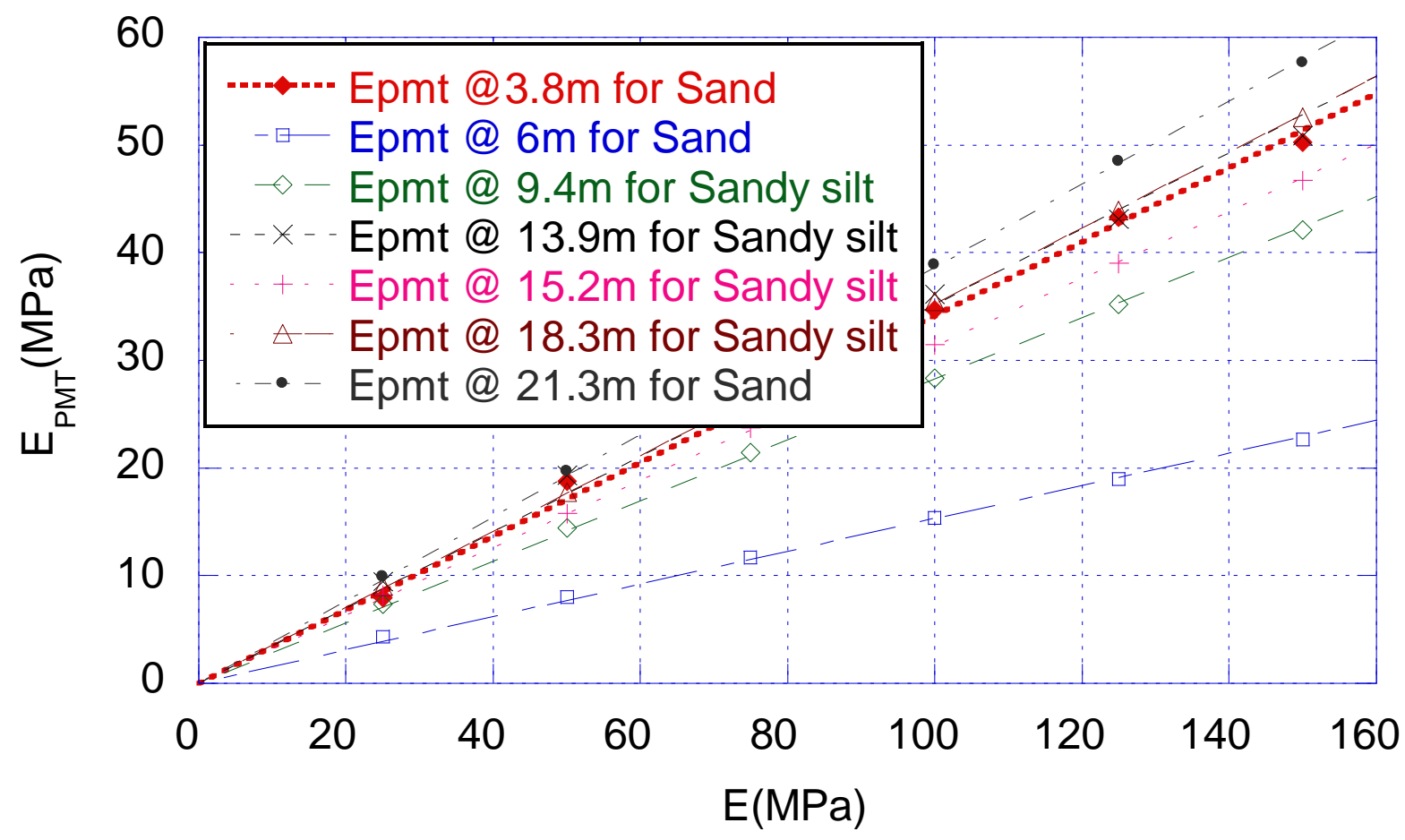

Fig 4.27 Linear relationships for $\mathrm{E}_{\mathrm{PMT}}$ vs E for cohesionless glacial tills at MD Station 


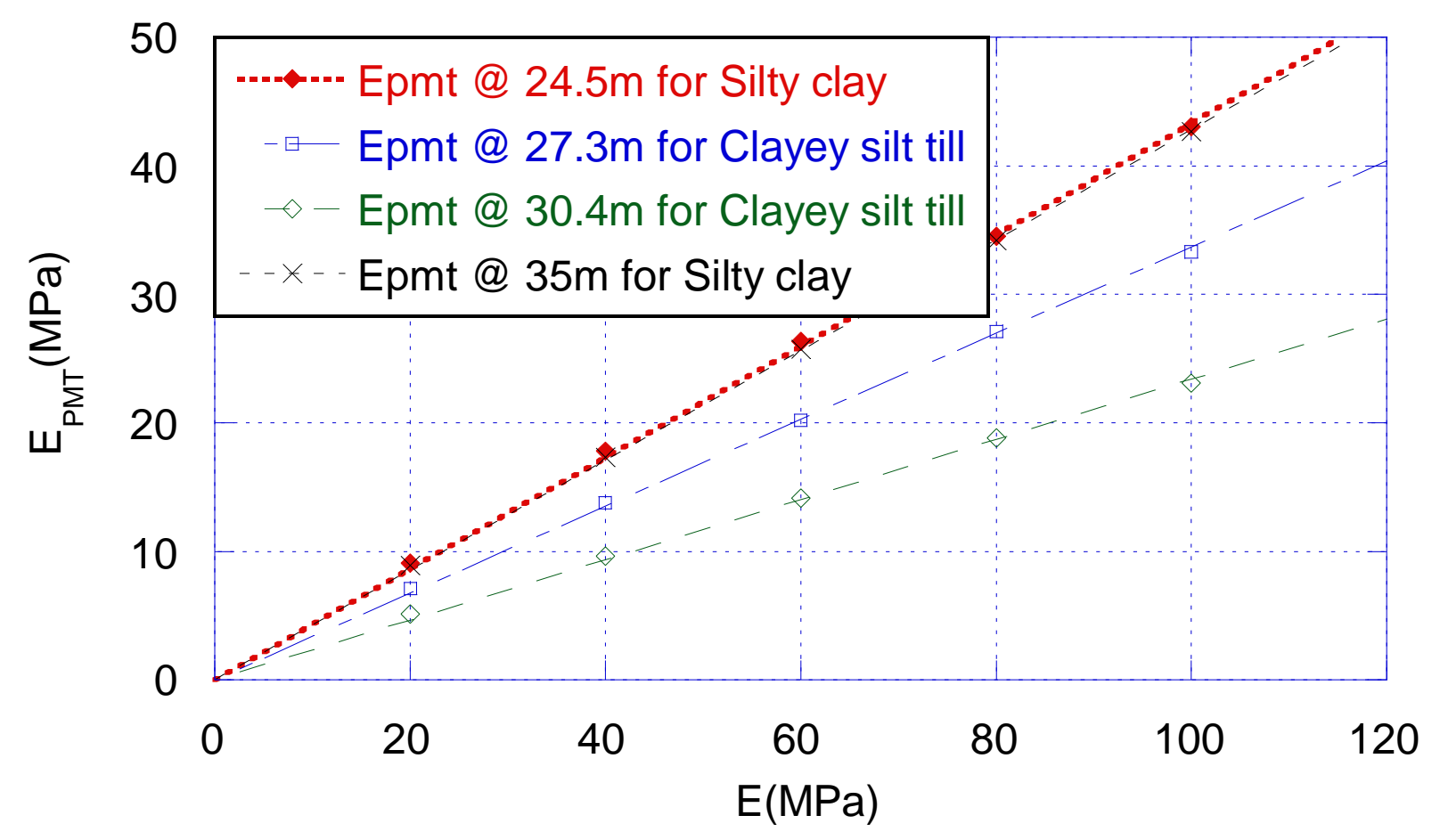

Fig 4.28 Linear relationships for $\mathrm{E}_{\mathrm{PMT}}$ Vs E for cohesive glacial tills at MD Station

In order to compare with Sedran et al. (2013), the linear relationship with intercept correlation equations are developed between PMT and Young modulus. The Sedran et al. (2013) suggested that, if a relation between $E$ and $E_{\text {PMT }}$ exists, it would be similar to $E=a+b E_{\text {PMT }}$. In this study, the same format of the equation is achieved, and is tabulated in Table 4.7.

Table 4.7 Linear with intercept correlation equations for glacial tills at MD Station

\begin{tabular}{|c|c|c|c|}
\hline Depth $(\mathrm{m})$ & Soil type & Correlation equation & $\mathrm{R}^{2}$ \\
\hline 3.8 & Sand & $\mathrm{E}=2.97 \mathrm{E}_{\mathrm{PMT}}-1.99$ & 1.0 \\
\hline 6.0 & Sand & $\mathrm{E}=6.85 \mathrm{E}_{\mathrm{PMT}}-4.96$ & 1.0 \\
\hline 9.4 & Sandy silt & $\mathrm{E}=3.60 \mathrm{E}_{\mathrm{PMT}}-1.83$ & 1.0 \\
\hline 13.9 & Sandy silt & $\mathrm{E}=3.07 \mathrm{E}_{\mathrm{PMT}}-8.79$ & 1.0 \\
\hline 15.2 & Sandy silt & $\mathrm{E}=3.24 \mathrm{E}_{\mathrm{PMT}}-1.63$ & 1.0 \\
\hline 18.3 & Sandy silt & $\mathrm{E}=2.87 \mathrm{E}_{\mathrm{PMT}}-1.24$ & 1.0 \\
\hline 21.3 & Sand & $\mathrm{E}=2.62 \mathrm{E}_{\mathrm{PMT}}-1.29$ & 1.0 \\
\hline 24.5 & Silty clay & $\mathrm{E}=2.36 \mathrm{E}_{\mathrm{PMT}}-1.75$ & 1.0 \\
\hline
\end{tabular}




\begin{tabular}{|c|c|c|c|}
\hline 27.3 & Clayey silt till & $\mathrm{E}=3.04 \mathrm{E}_{\mathrm{PMT}}-1.77$ & 1.0 \\
\hline 30.4 & Clayey silt till & $\mathrm{E}=4.44 \mathrm{E}_{\mathrm{PMT}}-2.82$ & 1.0 \\
\hline 35 & Silty clay & $\mathrm{E}=2.37 \mathrm{E}_{\mathrm{PMT}}-1.07$ & 1.0 \\
\hline
\end{tabular}

\subsubsection{VALIDATE THE RESULTS}

To validate the results the developed correlation equations are used to predict the Young's modulus for the field PMT modulus $\left(\mathrm{E}_{\mathrm{PMT}}\right)$ which is conducted in the MD Station in the ECLRT project. Then these predicted Young's modulus are used as input parameters in the simulation model in the Plaxis 2D. These simulations are carried out at each depth according to MD Station borehole \#101 soil profiles. Then PMT modules ( $\left.\mathrm{E}_{\mathrm{PMT}}\right)$ are calculated by using the Equation 2.8 in the Chapter 2(Section 2.2.2.3) from the linear portion of the pressure vs radial strain curves. The calculated PMT modules $\left(\mathrm{E}_{\mathrm{PMT}}\right)$ are same as the field values. In addition, the $\mathrm{E}$ values are calculated analytically by using Pasturel's formula which is shown in the Chapter 2 (Section 2.3.8). Analytical $\mathrm{E}$ values seem to be similar to the predicted values for cohesionless glacial soil but not the same for cohesive glacial soil. Analytical and predicted $\mathrm{E}$ values are both tabulated in Table 4.8. The predicted $\mathrm{E}$ values for sand vary from 75 to $172 \mathrm{MPa}$. According to Bowles (1996), E value for dense sand is 50 to $81 \mathrm{MPa}$. But $\mathrm{E}$ values vary for loose glacial tills from 10 to $150 \mathrm{MPa}$ and dense glacial tills from 150 to $720 \mathrm{MPa}$. From this study the predicted $\mathrm{E}$ values vary from 53 to $234 \mathrm{MPa}$. The studied values are within the Bowles' (1996) range.

Table 4.8 Summary of predicted and analytical E and calculated $\mathrm{E}_{\mathrm{PMT}}$ at MD Station

\begin{tabular}{|c|c|c|c|c|c|c|}
\hline $\begin{array}{l}\text { Depth } \\
(\mathrm{m})\end{array}$ & Soil type & $\begin{array}{c}\text { Field } \\
\text { PMT E EMT } \\
(\mathrm{MPa})\end{array}$ & $\begin{array}{c}\text { Predicted } \\
\text { E (MPa) }\end{array}$ & $\begin{array}{c}\text { Calculated EPMT } \\
\text { from the FEM } \\
\text { Simulation (MPa) }\end{array}$ & $\begin{array}{c}\text { Analytical E } \\
\text { from Pasturel's } \\
\text { formula (MPa) }\end{array}$ & $\alpha=\frac{E_{P M T}}{E}$ \\
\hline 3.8 & Sand & 0.2 & 0.60 & 0.24 & 1.05 & $0 . .34$ \\
\hline 6.0 & Sand & 25.8 & 172 & 25.90 & 200 & 0.15 \\
\hline 9.4 & Sandy silt & 40.8 & 146 & 41.06 & 144 & 0.28 \\
\hline 13.9 & Sandy silt & 38.6 & 110 & 39.03 & 104 & 0.35 \\
\hline
\end{tabular}




\begin{tabular}{|c|c|c|c|c|c|c|}
\hline 15.2 & Sandy silt & 27.8 & 90 & 28.30 & 52 & 0.31 \\
\hline 18.3 & Sandy silt & 28.9 & 83 & 29.50 & 23 & 0.35 \\
\hline 21.3 & Sand & 29.1 & 75 & 29.20 & 28 & 0.39 \\
\hline 24.5 & Silty clay & 36.2 & 84 & 36.20 & 8 & 0.43 \\
\hline 27.3 & Clayey silt till & 46.2 & 136 & 45.30 & 3 & 0.34 \\
\hline 30.4 & Clayey silt till & 53.9 & 234 & 53.30 & 3 & 0.23 \\
\hline 35.0 & Silty clay & 22.7 & 53 & 22.50 & 5 & 0.43 \\
\hline
\end{tabular}

\subsection{SUMMARY}

In this chapter, the PMT modulus ( $\mathrm{E}_{\mathrm{PMT}}$ ) is back calculated for glacial tills at MD Station in the ECLRT project in Toronto. The PMT is investigated using FEM analysis. The FEM analysis is performed with Mohr-Coulomb models which is linear elastic perfectly plastic constitutive model. This model requires five parameters (E, c, $\varphi, \psi$ and $v$ ). These parameters are used from ECLRT geoengineering factual data reports to simulate the model for each types of soil in the MD Station. The site contains glacial tills which consist of cohesionless glacial till such as sand and sandy silt from $3.8 \mathrm{~m}$ to $21.3 \mathrm{~m}$ and cohesive glacial tills such as silty clay and clayey silt till from $21.3 \mathrm{~m}$ to $35 \mathrm{~m}$.

First the model is created by using Plaxis 2D then validated by using one of the literature model Levasseur et al. (2009). The simulation is done to get the pressure (p) vs volumetric strain $\left(\frac{\Delta v}{V}\right)$ curve which show that curve is well best fit to the literature curve. Further to evaluate the mesh dependency, the same model is used. The fine mesh coarseness gave exactly the same curve which is compared with the literature model Levasseur et al. (2009).

Then the PMTs are analyzed numerically using Plaxis 2D. After the simulations are executed, pressure (p) vs radial strain curves are obtained to calculate the PMT modulus (E different values of Young's modulus in each depth according to MD borehole 101-PMT soil profile. The correlation equations are developed between PMT ( $\left.\mathrm{E}_{\mathrm{PMT}}\right)$ and Young's (E) modulus 
in each depth for different types of glacial tills. Then the Young's modulus (E) is predicted by using the correlation equation for the field PMT modulus ( $\left.\mathrm{E}_{\mathrm{PMT}}\right)$. The predicted $\mathrm{E}$ values for the glacial till vary from 53 to $243 \mathrm{MPa}$. These values are very good agreements with Bowles' (1992) ranges. The Bowles (1992) suggested E values for glacial tills that vary from 10 to 720 $\mathrm{MPa}$.

Then the Menard " $\alpha$ " factors are suggested for different types of glacial tills at MD Station. According to Menard, the " $\alpha$ " factors are between 0 and 1. In this study, these factors are retrieved by the results of the numerical simulations of the PMT. There is a good agreement with the Menard " $\alpha$ " factors. The summary of the $\mathrm{E}_{\mathrm{PMT}}$, E and Menard " $\alpha$ " factors for glacial tills at MD Station are shown in Table 4.9.

Further the linear relationship with intercept correlation equations are developed between PMT and Young modulus. There is a very good agreement with Sedran et al. (2013) due to the similar equation format of $\mathrm{E}=\mathrm{a}+\mathrm{b} \mathrm{E}_{\mathrm{PMT}}$.

Table 4.9 Summary of the E $\mathrm{PMT}_{\text {, }} \mathrm{E}$ and Menard " $\alpha$ " factors for MD Station

\begin{tabular}{|c|c|c|c|c|}
\hline Depth(m) & Soil types & $\begin{array}{c}\text { PMT modulus (EMT) } \\
(\mathrm{MPa})\end{array}$ & $\begin{array}{c}\text { Young's modulus (E) } \\
(\mathrm{MPa})\end{array}$ & $\alpha=\frac{E_{P M T}}{E}$ \\
\hline 3.8 & Sand & 0.20 & 0.60 & 0.34 \\
\hline 6.0 & Sand & 25.8 & 172 & 0.15 \\
\hline 9.4 & Sandy silt & 40.8 & 110 & 0.28 \\
\hline 13.9 & Sandy silt & 38.6 & 90 & 0.35 \\
\hline 15.2 & Sandy silt & 27.8 & 83 & 0.35 \\
\hline 18.3 & Sandy silt & 28.9 & 84 & 0.39 \\
\hline 21.3 & Sand & 29.1 & 136 & 0.43 \\
\hline 24.5 & Silty clay & 36.2 & 234 & 0.34 \\
\hline 27.3 & Clayey silt till & 46.2 & 53 & 0.23 \\
\hline 30.4 & Clayey silt till & 53.9 & & 0.43 \\
\hline 35.0 & Silty clay & 22.7 & & 75 \\
\hline
\end{tabular}




\section{CHAPTER 5: CONCLUSIONS AND RECOMMENDATIONS FOR FUTURE RESEARCH}

\subsection{MAIN CONCLUSIONS}

This study is performed based on a comprehensive geotechnical investigation program for a light rail transit (LRT) project in the City of Toronto. The following main conclusions are made from this investigation.

(1) The field SPT-N values are corrected and the ratio of corrected SPT-N to field measured SPT-N which is $\left(\frac{\left(N_{1}\right)_{60}}{N_{F}}\right)$ is recommended for glacial tills.

(2) The ranges of SPT-N, $E_{P M T}$ and $P_{L}$ with all data and corrected and filtered data format for glacial tills are suggested.

(3) The statistical correlation equations between SPT-N values with PMT parameters such as $\mathrm{PM}$ modulus $\left(\mathrm{E}_{\mathrm{PMT}}\right)$ and pressure limit $\left(\mathrm{P}_{\mathrm{L}}\right)$ with whole data as well as the corrected and filtered data format for glacial tills are developed.

(4) The $\mathrm{E}_{\mathrm{PMT}} / \mathrm{P}_{\mathrm{L}}$ ratios for sand and glacial till are also recommended.

(5) The correlation equations between PM modulus with Young's modulus for glacial tills are also suggested.

(6) The Menard " $\alpha$ " factors for glacial tills are also recommended. 


\subsection{RECOMMENDATIONS FOR FUTURE RESEARCH}

The following recommendations are made for future research:

(1) There are many possible applications to correct the field measured SPT-N. Since there is not any general agreement on these application of correction of field measured SPT-N. In contrast to heavy criticisms about the SPT-N correction, there is strong need and necessity to carry out a suitable research on correction methods which are more suitable for local conditions.

(2) This study also proves once more, the correlation between in-situ test parameters still involves a large amount of uncertainties as presented by many researchers and they should not be preferred unless there is not any other data available. Therefore it is recommended to carry out another study in the glacial tills in these areas in the future in order to provide a good relationship.

(3) The correlation between SPT-N and PMT has been investigated by many researchers in the past. They mentioned that the scatter in the data is considerably large which makes the correlation essentially useless in design. Due to that more theoretical study is needed to develop a sound rationale to filter the data to minimize the scatters.

(4) The future study was recommended to predict the undrained shear strength from net limit pressure of PMT and suggest the $\beta$ factor for glacial tills. Then develop the correlation equations between undrained shear strength and SPT-N for glacial tills.

(5) In the case of FEM simulation of PMT, the FEM provides efficient results. Even though the program needs many input parameters and may be complicated to use. Due to that the research is recommended, in order to develop a best curve fitting methodology to derive the soil strength parameters quickly and more accurately. 
(6) Model the PMT in glacial tills by using other constitutive models such as hardening soil model for sand and soft soil creep model for silty clay. But it is more time consuming to compare the results from different constitutive models. 


\section{REFERENCES}

ASTM D 4719-00 (2000). Standard tests method for pre-bored pressuremeter testing in soils. Annual book of ASTM standards, vol 04.08.

ASTM D 1586-11 (2014). Standard test method for standard penetration test (SPT) and splitbarrel sampling of soils. Annual book of ASTM standards.

Baguelin, F., Jezequel, J. F. and Shields, D.H. (1978). The Pressuremeter and foundation engineering, Trans Tech. Publications, Clausthal, Germany. $617 \mathrm{p}$.

Baker, C.L., Lahti, L.R., and Roumbanis, D.C. (1998). Urban Geology of Toronto and surrounding area. Urban Geology of Canadian Cities. Edited by: P.F. Karrow, 42, 323352.

Bolton, M.D. and Whittle, R. W. (1999). A nonlinear elastic/perfectly plastic analysis for plane strain undrained expansion tests. Geotechnique, 49(1), 133-141.

Boone, S. J., Shirlaw, J.N. et al. (1996). Boulder assessment report for TTC Sheppard Subway, Golder associates report no: S-GIR3-R. Toronto.

Boone, S. J. and Westland, J. (2008). Geotechnical summary report for tunnel boring machine procurement for the Toronto-York Spadina Subway extension (TYSSE), Golder associates report no: 08-111-0039-R01.

Bowles, J.E. (1997). Foundation analysis and design. The McGraw-Hill Co., Inc., Singapore, $5^{\text {th }}$ edition.

Bozbey, I. and Togrol, E. (2010). Correlation of standard penetration test and pressuremeter data. A case study from Istanbul, Turkey. Bull eng geol environ.

Braja, M. Das. (1990). Principles of Foundation Engineering, $5^{\text {th }}$ ed., Cole engineering division.

Briaud, J.L. (1992). The pressuremeter, A. A. Balkema, Rotterdam, Netherlands.

Brinkgreve, R.B.J. and Vermeer, P.A. (1998). Plaxis. Finite element code for soil and rock analysis, Balkema, Rotterdam, The Netherlands.

Burd, H. (1999). The history of PLAXIS. Beyond 2000 in computational geotechnics: 10 years of PLAXIS international; Proceedings of the international symposium beyond 2000 in computational geotechnics, Amsterdam, The Netherlands, 18-20 March 1999, Taylor \& Francis group.

Cambou, B. and Bahar, R. (1993). Utilisation de I'essai pressiometrique pour I' identification de parametres intrinseques du comportement dusol. Revue Franqaise de Geotechnique, 63, $39-50$. 
Campanella, R.G., Berzins, W.E. and Shields, D.H. (1979). A preliminary evaluation of Menard pressuremeter, cone penetrometer and standard penetration test in the lower main land, British Columbia. Soil mechanics series no: 40.

Canadian Geotechnical Society, (2006). Canadian Foundation Engineering Manual. $4^{\text {th }}$ ed., The Canadian Geotechnical Society Co \& Bi Tech, publishers Ltd. Canada.

Cao, L., Peaker, S. and Ahmad, S. (2015). Pressuremeter tests in glacial tills in Toronto, Symposium International ISP7/Pressio.

Clarke, B.G. (1995). Pressuremeter in Geotechnical Design. $1^{\text {st }}$ ed.,Chapman \& Hall, Glasgow.

Eglinton Cross Town (LRT), Geoengineering factual data report.

Fawaz, A., Hagechehade, F. and Farah, E. (2014). A study of the pressuremeter modulus and its comparison to the elastic modulus of soil. Study of civil engineering and architecture (SCEA).

Finn, P.S., Nisbet, R.M. and Hawkins, P.G. (1984). Guidance on pressuremeter, flat dilatometer and cone penetration tests in sand, Geotechnique, vol.34, no:1, pp.81-97.

Gibson, R.E. and Anderson, W.F. (1961). In - situ measurement of soil properties with the pressuremeter. Civil Eng.

Houari, O. and Abdeldjalil, Z. (2015). Numerical modeling of the test on slope pressuremeter. International journal of emerging technology and advanced engineering. vol 5, issue 5.

Jacques, M. (2007). Numerical validation of an elastoplastic formulation of the conventional limit pressure measured with the pressuremeter test in cohesive soil. Journal of Geotechnical and Geoenvironmental Engineering. ASCE. September.

Karrow, P.F. (1967). Pleistocene geology of the Scarborough area. Ontario department of mines, Geological reports 46.

Karrow, P.F. and White, O.L. (1998). Urban geology of Canadian cities, Geological association of Canada, GAC special paper 42.

Kovacs, W.D. and Salomone, L.A. (1982). SPT hammer energy measurements. American Society of Civil Engineers, ASCE, Journal of the Geotechnical Engineering Division, vol.108, GT4, pp.599-620.

Kovacs, W.D., Yokel, F.Y., Salomone, L.A and Holtz, R.D. (1984). Liquefaction potential and the international SPT; Proceeding of the $8^{\text {th }}$ world conference on earthquake engineering, San Francisco, CA.

Kulhawy and Mayne (1990). Manual on estimating soil properties for foundation design, Electric power research institute, Palo Alto, CA 
Levasseur, S., Malecot, Y., Boulon, M. and Flavigny, E. (2009). Statistical inverse analysis based on genetic algorithm and principal component analysis. Application to excavation problems and pessuremeter tests. International journal for numerical and analytical methods in geomechanics. 34: 471-491.

Levasseur, S., Malecot, Y., Boulon, M. and Flavigny, E. (2008). Statistical inverse analysis based on genetic algorithm and principal component analysis. Methods and developments using synthetic data. International journal for numerical and analytical methods in geomechanics. 33: 1485-1511.

Manzari, M., Drevininkas, A., Olshansky, D. and Galaa, A. (2014). Behavioral modelling of Toronto glacial soils and implementation in numerical modeling. 67th Canadian Geotechnical Conference, Geo Regina.

Menard, L. (1965). Regle pour le Calcul de la Force Portante et du Tassement des Foundation en Fonction des Resultats Pressiometriques, Proceedings $6^{\text {th }}$ ICSMFE, Montreal, vol., pp. 295- 299.

Michel, G., Armando, A. and Antonio, G.C. (2008) Using a nonlinear constitutive law to compare Menard PMT and PLT E-moduli.

Monnet, J. (2007). Numerical validation of an elastoplastic formulation of the conventional limit pressure measured with the pressuremeter test in cohesive soil. Journal of geotechnical and geoenvironmental engineering. September.

Monnet, J. (2012). Elasto-plastic analysis of the pressuremeter test in granular soil part 2. Numerical study. European journal of environmental and civil engineering. vol 16, no.6 $715-729$.

Nahra, R. and Frank, R. (1986). Contributions numeriques et analytiques a I' etude de la consolidation autour du pressiometre. Research Rep. LPC No: 137, Laboratoire Central des Ponts et Chaussees, Paris.

Ng, R., Xue, T., Wheeler, C. and Campo, D. (2011). The Eglinton cross town light rail transit.14 ${ }^{\text {th }}$ Pan-Am conference on Soil Mechanics and Geotechnical Engineering. $64^{\text {th }}$ Canadian Geotechnical conference.

Ohya, H., Kazama, E. and Negishi, Y. (1982). Reverse osmotic concentration of aqueous ethylalcohol solutions. Analysis of data obtained with composite membranes (PEC), Kagaku Kogaku Ronbunshu, 8 (2): 144-149.

Owen, D.R.J. and Hinton, E. (1980). Finite elements in plasticity. Theory and practice. Pinerridge press limited, Swansea, U.K.

Phoon, K.K. and Kulhawy, F.H. (1999). Evaluation of geotechnical variability. Canadian geotech J 36:625-639.

Plaxis 2D. (2012). Material Model Manual. 
Plaxis 2D. (2012). Reference Manual.

Plaxis 2D. (2012). Tutorial Manual.

Potts, D. M. and Zdravkovic, L. (2001). Finite Element Analysis in Geotechnical Engineering. Thomas Telford, London.

Prapaharan, S., Chameau, J. L. and Holtz, R.D.(1989). Effect of strain rate on undrained strength derived from presssuremeter tests. Geotechnique, 39(4), 615-624.

Raquel, R. (2008). Characterization of Material Behavior by the pressuremeter test.

Robertson, P. K., Campanella, R. C. and Wightman, A.(1983). SPT-CPT correlations, American society of civil engineers, ASCE, Journal of the geotechnical engineering division, vol.109, GT11, pp. 1449-1459.

Schanz, T., Vermeer, P.A. and Bonnier, P.G. (2000). The hardening soil model. Formulation and verification. Beyond 2000 in computational geotechnics.10 years of Plaxis@ Balkema, Rotterdam, ISBN $905809040 \mathrm{X}$.

Schmertmann, J.H. and Palacios, A. (1979), Energy dynamics of SPT, American society of civil engineers, ASCE, Journal of the geotechnical engineering division, vol. 105, GT8, pp. 909-926.

Sedran, G., Failmezger, R.A. and Drevininkas, A. (2013). Relationship between Menard $\mathrm{E}_{\mathrm{M}}$ and Young's E moduli for cohesionless soils. Proceeding of the $18^{\text {th }}$ International conference on soil mechanics and geotechnical engineering, Paris 2013.

Seed, H.B., Tokimatsu, K., Harder, L.F. and Chung, R.M. (1984). Influence of SPT procedures in soil liquefaction resistance evaluations. Report no: UCB/EERC-84/15, Berkeley. Reprinted in journal of geotechnical engineering, ASCE, vol. 111, no.12, pp 1425-1445.

Sharp, D.R. (1980). Quaternary geology of Toronto and surrounding area. Ontario geological survey, Geological series preliminary map, p 2204.

Sharpe, D.R., Barnett, P. J. et al. (1999). Regional Geological Mapping of Oak Ridges Moraine Greater Toronto Area - Southern Ontario, in current research 1999- E, Geological Survey of Canada, pp 123-136.

Silvestri, V. (2003). Assessment of self - boring pressuremeter tests in sensitive clay. Can. Geotech. J., 40, 362-387.

Silvestri, V. (2004). Disturbance effects in pressuremeter tests in clay. Can. Geotech. J., 41, 738759.

Sivrikaya, O., Togrol, E., (2007), Turkiye de SPT N Degeri ile Dnce Daneli Zeminlerin Drenajsiz Kayma Mukavemeti A rasindaki Dliskiler, Technical magazine of chamber of civil engineers, pp 4229 - 4246, paper no: 279. 
Skempton, A.W. (1986). Standard penetration test, procedures and effects in sands of overburden, relative density, particle size, aging and over- consolidation. Geotechnique, vol.36, no. 3, pp. 425-447.

Terzaghi, K. and Peck, R.B. (1967). Soil mechanics in enginering practice, second edition, John Wiley and Sons, New York, 729p.

Thorburn, S. (1986). Field testing: standard penetration test, engineering geology special publication, no: 2, Geological society.

Timoshenko, S and Goodier, J.N. (1951). Theory of elasticity. McGraw Hill, New York.

Toronto transit commission geotechnical standards. (2014). version 8

Yagiz, S., Akyol, E. and Sen, G. (2008). Relationship between the standard penetration test and the pressuremeter test on sandy silty clays. A case study from Denizli. Bulletin of engineering geology and the environment, 67(3), 405-410. 


\section{APPENDICES}


APPENDIX 3.1

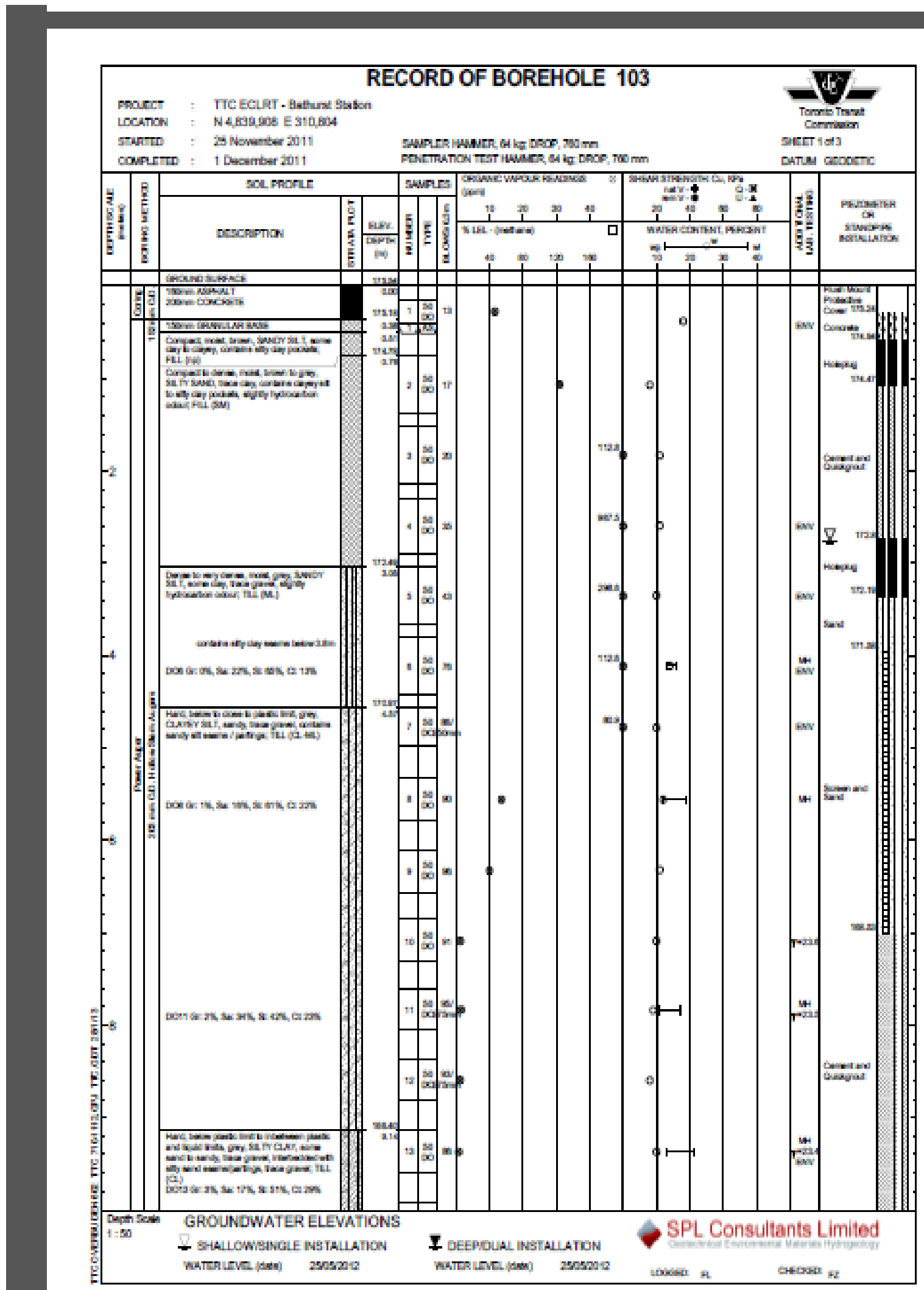




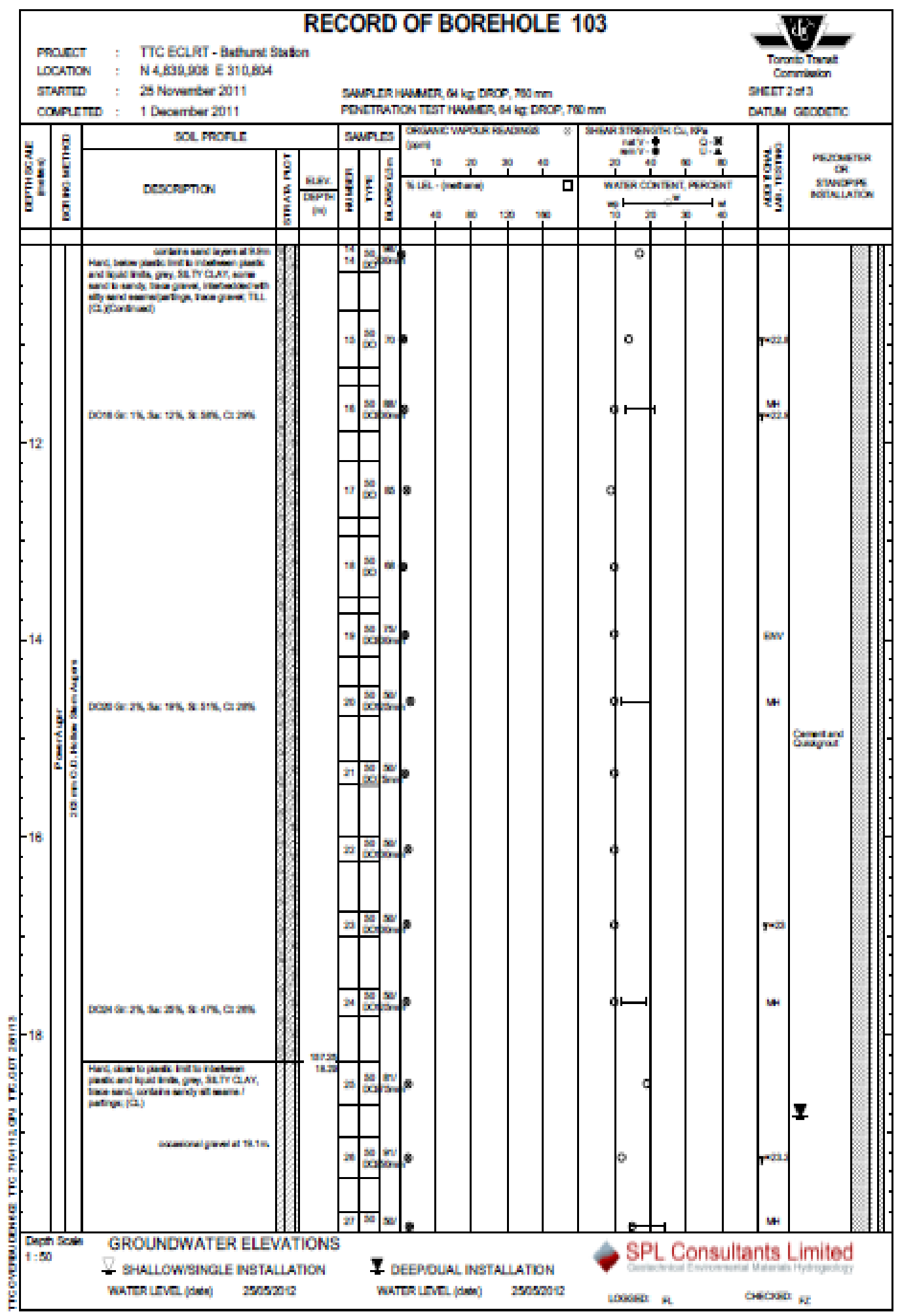




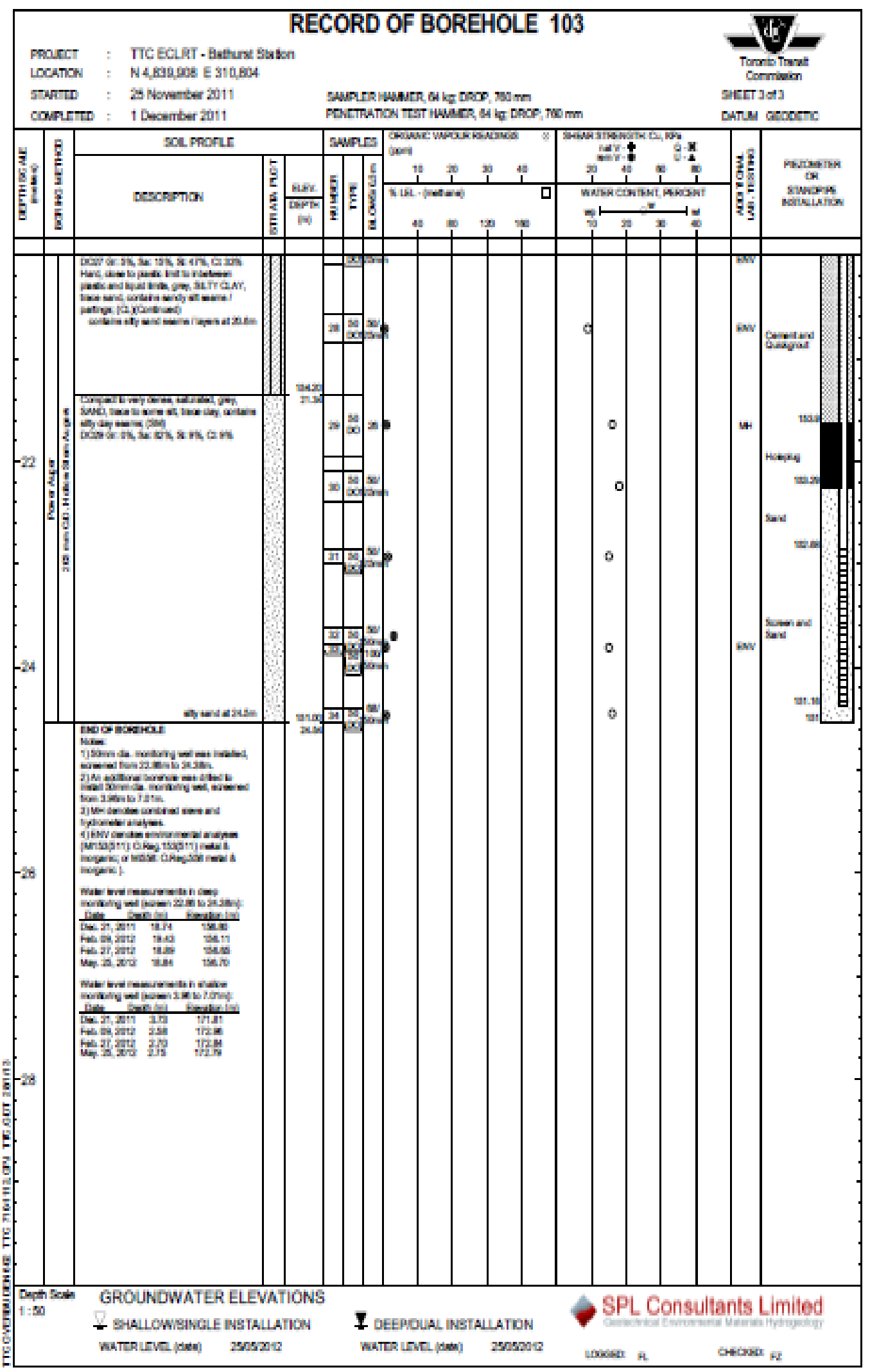




\section{APPENDIX 3.2}

\section{SPT-N CORRECTION}

Sample calculation for SPT-N correction for Bathurst Station:

First correction is performed according to Cao et al. (2015) for field measured SPT-N for penetration depth.

$N_{F}=\frac{305 N}{\Delta s}$

Where $\quad N_{F}$ - Corrected SPT-N value

$\mathrm{N}$ - Field recorded SPT-N value

$\Delta \mathrm{s}$ - Measured penetration depth in $\mathrm{mm}$

Table A3.1 Summary of $\mathrm{N}_{\mathrm{C}}$ calculation

\begin{tabular}{|c|c|c|c|c|}
\hline Depth $(\mathrm{m})$ & Soil types & $\begin{array}{c}\text { Field measured } \\
\text { SPT-N value }\end{array}$ & $\begin{array}{c}\text { Penetration depth } \\
(\Delta \mathrm{S}) \mathrm{in} \mathrm{mm}\end{array}$ & $\mathrm{N}_{\mathrm{F}}=\frac{305 \mathrm{~N}}{\Delta s}$ \\
\hline 3.7 & Sandy silt & 43 & 305 & $=\frac{305 \times 43}{305}=43$ \\
\hline 7.1 & Silty clay till & 91 & 305 & $=\frac{305 \times 91}{305}=91$ \\
\hline 10.5 & Silty clay till & 98 & 200 & $=\frac{305 \times 98}{200}=150$ \\
\hline 13.6 & Clayey silt till & 68 & 305 & $=\frac{305 \times 68}{305}=68$ \\
\hline 16.4 & Clayey silt till & 50 & 100 & $=\frac{305 \times 50}{100}=153$ \\
\hline 19.8 & Silty clay & 50 & 125 & $=\frac{305 \times 50}{125}=122$ \\
\hline 22.8 & Sand & 50 & 125 & $=\frac{305 \times 50}{122}=122$ \\
\hline 25.6 & Silty sand & 68 & 150 & $=\frac{305 \times 68}{150}=138$ \\
\hline
\end{tabular}


Second correction is performed according to the CFEM (2006).

$$
\begin{aligned}
& \left(N_{1}\right)_{60}=\mathrm{C}_{\mathrm{E}} \mathrm{C}_{\mathrm{N}} \mathrm{C}_{\mathrm{R}} \mathrm{C}_{\mathrm{B}} \mathrm{C}_{\mathrm{S}} N_{F} \\
& \left(N_{1}\right)_{60}=\mathrm{C}_{\mathrm{N}} N_{60} \\
& N_{60}=\mathrm{C}_{\mathrm{E}} N_{F} \\
& \mathrm{C}_{\mathrm{N}}=\left(\frac{P}{\sigma^{1}}\right)^{0.5} \\
& \mathrm{C}_{\mathrm{E}}=\frac{E R_{R}}{60}
\end{aligned}
$$

Where $\mathrm{C}_{\mathrm{E}}$ - Hammer energy correction factor

$E R_{R}-$ Rod energy ratio

$\mathrm{C}_{\mathrm{N}}$ - Overburden pressure correction factor

P - Atmospheric pressure

$\sigma^{\prime}$ - Effective overburden pressure

$\mathrm{C}_{\mathrm{R}}$ - Rod length correction factor

$\mathrm{C}_{\mathrm{B}}$ - Borehole diameter correction factor

$\mathrm{C}_{\mathrm{S}}$ - Sampler correction factor

$\mathrm{N}_{\mathrm{F}}$ - Corrected SPT-N value for penetration depth

$\mathrm{N}_{60}$ - SPT-N value corrected to $60 \%$ of theoretical free fall hammer energy

$\left(N_{1}\right)_{60}$ - SPT-N value correctd for both vertical effective stress and input energy

Calculation procedure for overburden pressure correction factor $\left(\mathrm{C}_{\mathrm{N}}\right)$ :

Water table is located at $2.8 \mathrm{~m}$ below the grade level in this borehole. Density of water $\left(\gamma_{\mathrm{w}}\right)$ is $9.81 \mathrm{kN} / \mathrm{m}^{3}$ and Atmospheric pressure (P) $100 \mathrm{Kpa}$. Dry density of sandy silt is $17 \mathrm{kN} / \mathrm{m}^{3}$ 
Table A3.2 Summary of $\mathrm{C}_{\mathrm{N}}$ calculations

\begin{tabular}{|c|c|l|c|}
\hline Depth $(\mathrm{m})$ & $\gamma\left(\mathrm{kN} / \mathrm{m}^{3}\right)$ & \multicolumn{1}{|c|}{$\sigma^{\prime}(\mathrm{kPa})$} & $\mathrm{C}_{\mathrm{N}=}\left(\frac{P}{\sigma^{\prime}}\right)^{0.5}$ \\
\hline 3.7 & 21 & $2.8^{*} 17+(3.7-2.8)^{*}(21-9.81)=57.671$ & 1.316804 \\
\hline 7.1 & 23.6 & $57.671+(7.1-3.7)(23.6-9.81)=104.557$ & 0.977965 \\
\hline 10.5 & 22.8 & $104.557+(10.5-7.1)(22.8-9.81)=148.723$ & 0.819994 \\
\hline 13.6 & 22.9 & $148.723+(13.6-10.5)(22.9-9.81)=189.302$ & 0.726813 \\
\hline 16.4 & 23 & $189.302+(16.4-13.6)(23-9.81)=226.234$ & 0.664846 \\
\hline 19.8 & 23.2 & $226.234+(19.8-16.4)(23.2-9.81)=271.76$ & 0.606607 \\
\hline 22.8 & 23.2 & $271.76+(22.8-19.8)(23.2-9.81)=311.93$ & 0.566202 \\
\hline 25.6 & 23.2 & $311.93+(25.6-22.8)(23.2-9.81)=349.422$ & 0.534964 \\
\hline
\end{tabular}

Table A3.3 Summary of correction factors and $\left(N_{1}\right)_{60}$ calculations

\begin{tabular}{|c|c|c|c|c|c|c|c|}
\hline Depth(m) & $\mathrm{C}_{\mathrm{E}}$ & $\mathrm{C}_{\mathrm{N}}$ & $\mathrm{C}_{\mathrm{R}}$ & $\mathrm{C}_{\mathrm{B}}$ & $\mathrm{C}_{\mathrm{S}}$ & $\mathrm{N}_{\mathrm{F}}$ & $\left(N_{1}\right)_{60}$ \\
\hline 3.7 & 1 & 1.316804 & 0.7 & 1 & 1 & 43 & 39.63581 \\
\hline 7.1 & 1 & 0.977965 & 0.95 & 1 & 1 & 91 & 84.5451 \\
\hline 10.5 & 1 & 0.819994 & 1 & 1 & 1 & 150 & 122.5482 \\
\hline 13.6 & 1 & 0.726813 & 1 & 1 & 1 & 68 & 49.42325 \\
\hline 16.4 & 1 & 0.664846 & 1 & 1 & 1 & 153 & 101.3890 \\
\hline 19.8 & 1 & 0.606607 & 1 & 1 & 1 & 122 & 74.00602 \\
\hline 22.8 & 1 & 0.566202 & 1 & 1 & 1 & 122 & 69.07665 \\
\hline 25.6 & 1 & 0.534964 & 1 & 1 & 1 & 138 & 73.96774 \\
\hline
\end{tabular}

Table A3.4 Summary of the corrected SPT-N values and ratios of $\frac{\left(N_{1}\right)_{60}}{N_{F}}$ for Bathurst Station

\begin{tabular}{|c|c|c|c|c|c|}
\hline Depth $(\mathrm{m})$ & Soil types & $\begin{array}{c}\text { Field measured } \\
\text { SPT-N }\end{array}$ & $\mathrm{N}_{\mathrm{F}}$ & $\left(N_{1}\right)_{60}$ & Ratio $\frac{\left(N_{1}\right)_{60}}{N_{F}}$ \\
\hline 3.7 & Sandy silt & 43 & 43 & 40 & 0.9 \\
\hline 7.1 & Silty clay till & 91 & 91 & 85 & 0.9 \\
\hline
\end{tabular}




\begin{tabular}{|c|c|c|c|c|c|}
\hline 10.5 & Silty clay till & 98 & 150 & 123 & 0.8 \\
\hline 13.6 & Clayey silt till & 68 & 68 & 49 & 0.7 \\
\hline 16.4 & Clayey silt till & 50 & 153 & 101 & 0.7 \\
\hline 19.8 & Silty clay & 50 & 122 & 74 & 0.6 \\
\hline 22.8 & Sand & 50 & 122 & 69 & 0.6 \\
\hline 25.6 & Silty sand & 68 & 138 & 74 & 0.5 \\
\hline
\end{tabular}

(1) Allen Station

Table A3.5 Summary of the corrected SPT-N values and ratios of $\frac{\left(N_{1}\right)_{60}}{N_{F}}$ for Allen Station from Borehole AL12-PMT

\begin{tabular}{|c|c|c|c|c|c|}
\hline Depth $(\mathrm{m})$ & Soil types & $\begin{array}{c}\text { Field measured } \\
\text { SPT-N }\end{array}$ & $\mathrm{N}_{\mathrm{F}}$ & $\left(N_{1}\right)_{60}$ & Ratio $\frac{\left(N_{1}\right)_{60}}{N_{F}}$ \\
\hline 4.95 & Clayey silt till & 33 & 33 & 26 & 0.8 \\
\hline 7.62 & Clayey silt till & 51 & 51 & 37 & 0.7 \\
\hline 10.87 & Silty clay & 58 & 58 & 37 & 0.6 \\
\hline 13.92 & Silty clay & $89 / 250 \mathrm{~mm}$ & 109 & 62 & 0.6 \\
\hline 16.97 & Silty clay & $50 / 75 \mathrm{~mm}$ & 203 & 110 & 0.5 \\
\hline 20.02 & Sand & $83 / 250 \mathrm{~mm}$ & 101 & 52 & 0.5 \\
\hline 23.06 & Sand & $57 / 150 \mathrm{~mm}$ & 116 & 57 & 0.5 \\
\hline 26.01 & Silty sand & $51 / 150 \mathrm{~mm}$ & 104 & 48 & 0.5 \\
\hline 30.68 & Sand & $50 / 150 \mathrm{~mm}$ & 102 & 45 & 0.4 \\
\hline
\end{tabular}

Table A3.6 Summary of the corrected SPT-N values and ratios of $\frac{\left(N_{1}\right)_{60}}{N_{F}}$ for Allen Station from Borehole AL20-PMT

\begin{tabular}{|l|l|l|l|l|l|}
\hline Depth $(\mathrm{m})$ & Soil types & Field measured & $\mathrm{N}_{\mathrm{F}}$ & $\left(N_{1}\right)_{60}$ & Ratio $\frac{\left(N_{1}\right)_{60}}{N_{F}}$ \\
\hline
\end{tabular}




\begin{tabular}{|c|c|c|c|c|c|}
\hline & & SPT-N & & & \\
\hline 4.72 & Clayey silt till & 152 & 152 & 123 & 0.8 \\
\hline 7.77 & Silty clay till & 41 & 41 & 29 & 0.7 \\
\hline 10.82 & Silty clay & 49 & 49 & 31 & 0.6 \\
\hline 13.36 & Clayey silt till & $55 / 150 \mathrm{~mm}$ & 112 & 67 & 0.6 \\
\hline 14.63 & Clayey silt till & $72 / 150 \mathrm{~mm}$ & 146 & 85 & 0.6 \\
\hline 17.09 & Sand & $88 / 10 \mathrm{~mm}$ & 2684 & 1476 & 0.6 \\
\hline 19.71 & Sand & $104 / 225 \mathrm{~mm}$ & 141 & 74 & 0.5 \\
\hline 22.81 & Sand & $150 / 150 \mathrm{~mm}$ & 305 & 152 & 0.5 \\
\hline 25.98 & Sand & $50 / 75 \mathrm{~mm}$ & 203 & 97 & 0.5 \\
\hline 30.02 & Silty clay & 84 & 84 & 38 & 0.5 \\
\hline
\end{tabular}

(2) Avenue Station

Table A3.7 Summary of the corrected SPT-N values and ratios of $\frac{\left(N_{1}\right)_{60}}{N_{F}}$ for Avenue Station from Borehole MD101-PMT (i.e AV101A)

\begin{tabular}{|c|c|c|c|c|c|}
\hline Depth (m) & Soil types & $\begin{array}{c}\text { Field measured } \\
\text { SPT-N }\end{array}$ & $\mathrm{N}_{\mathrm{F}}$ & $\left(N_{1}\right)_{60}$ & Ratio $\frac{\left(N_{1}\right)_{60}}{N_{F}}$ \\
\hline 5.33 & Silty clay till & 37 & 37 & 31 & 0.8 \\
\hline 8.31 & Silty clay till & 38 & 38 & 28 & 0.7 \\
\hline 13.11 & Silt & 56 & 56 & 34 & 0.6 \\
\hline 14.76 & Silty clay & 38 & 38 & 22 & 0.6 \\
\hline 17.6 & Sandy silt & $50 / 100 \mathrm{~mm}$ & 153 & 80 & 0.5 \\
\hline 20.6 & Sand/Silty sand & $50 / 100 \mathrm{~mm}$ & 153 & 73 & 0.5 \\
\hline 23.93 & Sand & $50 / 130 \mathrm{~mm}$ & 117 & 54 & 0.5 \\
\hline 26.9 & Sand & $50 / 280 \mathrm{~mm}$ & 55 & 24 & 0.4 \\
\hline 30.02 & Silty sand & $50 / 130 \mathrm{~mm}$ & 117 & 50 & 0.4 \\
\hline 32.72 & Silty sand & $50 / 100 \mathrm{~mm}$ & 153 & 63 & 0.4 \\
\hline 34.82 & Sandy silt/Silt & 82 & 82 & 33 & 0.4 \\
\hline
\end{tabular}




\begin{tabular}{|c|c|c|c|c|c|}
\hline 37.44 & Silty clay & 47 & 47 & 19 & 0.4 \\
\hline 40.31 & Clayey silt till & $50 / 150 \mathrm{~mm}$ & 102 & 39 & 0.4 \\
\hline 43.23 & Clayey silt till & $50 / 100 \mathrm{~mm}$ & 153 & 57 & 0.4 \\
\hline 47.93 & Silty clay & $91 / 230 \mathrm{~mm}$ & 121 & 44 & 0.4 \\
\hline
\end{tabular}

(3) Bathurst Station

Table A3.8 Summary of the corrected SPT-N values and ratios of $\frac{\left(N_{1}\right)_{60}}{N_{F}}$ for Bathurst Station Borehole 103-PMT

\begin{tabular}{|c|c|c|c|c|c|}
\hline Depth (m) & Soil types & $\begin{array}{c}\text { Field measured } \\
\text { SPT-N }\end{array}$ & $\mathrm{N}_{\mathrm{F}}$ & $\left(N_{1}\right)_{60}$ & Ratio $\frac{\left(N_{1}\right)_{60}}{N_{F}}$ \\
\hline 3.7 & Sandy silt & 43 & 43 & 47 & 1.1 \\
\hline 7.1 & Silty clay till & 91 & 91 & 92 & 1.0 \\
\hline 10.5 & Silty clay till & $98 / 200 \mathrm{~mm}$ & 149 & 130 & 0.9 \\
\hline 13.6 & Clayey silt till & 68 & 68 & 52 & 0.8 \\
\hline 16.4 & Clayey silt till & $50 / 100 \mathrm{~mm}$ & 153 & 105 & 0.7 \\
\hline 19.8 & Silty clay & $50 / 125 \mathrm{~mm}$ & 122 & 76 & 0.6 \\
\hline 22.8 & Sand & $50 / 125 \mathrm{~mm}$ & 122 & 71 & 0.6 \\
\hline 25.6 & Silty sand & $68 / 150 \mathrm{~mm}$ & 138 & 76 & 0.6 \\
\hline
\end{tabular}

(4) Bayview Station

Table A3.9 Summary of the corrected SPT-N values and ratios of $\frac{\left(N_{1}\right)_{60}}{N_{F}}$ for Bayview Station Borehole BV100-PMT (i.e BV100B)

\begin{tabular}{|l|l|c|c|c|c|}
\hline Depth (m) & Soil types & $\begin{array}{c}\text { Field measured } \\
\text { SPT-N }\end{array}$ & $\mathrm{N}_{\mathrm{F}}$ & $\left(N_{1}\right)_{60}$ & Ratio $\frac{\left(N_{1}\right)_{60}}{N_{F}}$ \\
\hline
\end{tabular}




\begin{tabular}{|c|c|c|c|c|c|}
\hline 7.16 & Sandy silt & 57 & 57 & 58 & 1.0 \\
\hline 10.36 & Silt & 43 & 43 & 38 & 0.9 \\
\hline 13.31 & Sandy silt & 58 & 58 & 46 & 0.8 \\
\hline 16.36 & Sand/Sandy silt & 74 & 74 & 52 & 0.7 \\
\hline 19.33 & Sandy silt/Silty clay & 75 & 75 & 49 & 0.7 \\
\hline 22.86 & Silty clay & 36 & 36 & 22 & 0.6 \\
\hline 25.78 & Clayey silt till & 58 & 58 & 33 & 0.6 \\
\hline 28.58 & Clayey silt till & 85 & 85 & 46 & 0.5 \\
\hline 31.8 & Silt & $70 / 150 \mathrm{~mm}$ & 142 & 72 & 0.5 \\
\hline 34.7 & Silt & 78 & 78 & 38 & 0.5 \\
\hline
\end{tabular}

(5) Bermondsey Station

Table A3.10 Summary of the corrected SPT-N values and ratios of $\frac{\left(N_{1}\right)_{60}}{N_{F}}$ for Bermondsey Station Borehole BE05-PMT

\begin{tabular}{|c|c|c|c|c|c|}
\hline Depth $(\mathrm{m})$ & Soil types & $\begin{array}{c}\text { Field measured } \\
\text { SPT-N }\end{array}$ & $\mathrm{N}_{\mathrm{F}}$ & $\left(N_{1}\right)_{60}$ & Ratio $\frac{\left(N_{1}\right)_{60}}{N_{F}}$ \\
\hline 3.2 & Silty clay till & 20 & 20 & 17 & 0.9 \\
\hline 5.97 & Silty clay till & 13 & 13 & 10 & 0.8 \\
\hline 9.3 & Silty clay till & 15 & 15 & 10 & 0.7 \\
\hline 11.89 & Silty clay till & 10 & 10 & 6 & 0.6 \\
\hline 15.6 & Silty clay till & 08 & 08 & 4 & 0.5 \\
\hline 18.62 & Silty clay till & 12 & 12 & 6 & 0.5 \\
\hline 21.59 & Silty clay till & 13 & 13 & 6 & 0.5 \\
\hline 24.41 & Clayey silt till & 15 & 15 & 7 & 0.5 \\
\hline 27.69 & Silty clay till & 26 & 26 & 12 & 0.5 \\
\hline 30.68 & Silty clay & 14 & 14 & 6 & 0.4 \\
\hline
\end{tabular}

(6) Blackcreek Station 
Table A3.11 Summary of the corrected SPT-N values and ratios of $\frac{\left(N_{1}\right)_{60}}{N_{F}}$ for Blckcreek Station Borehole BH7 - PMT

\begin{tabular}{|c|c|c|c|c|c|}
\hline Depth (m) & Soil types & $\begin{array}{c}\text { Field measured } \\
\text { SPT-N }\end{array}$ & $\mathrm{N}_{\mathrm{F}}$ & $\left(N_{1}\right)_{60}$ & Ratio $\frac{\left(N_{1}\right)_{60}}{N_{F}}$ \\
\hline 6.05 & Gravelly sand & 7 & 7 & 9 & 1.3 \\
\hline 8.69 & Silty clay & 14 & 14 & 15 & 1.0 \\
\hline 11.84 & Silty clay & 9 & 9 & 8 & 0.9 \\
\hline 15.09 & Silty clay till & 14 & 14 & 11 & 0.8 \\
\hline 18.06 & Silty clay & 8 & 8 & 6 & 0.8 \\
\hline 20.85 & Clayey silt till & 6 & 6 & 4 & 0.7 \\
\hline 24.03 & Clayey silt till & 20 & 20 & 12 & 0.6 \\
\hline 27.53 & Clayey silt till & 13 & 13 & 7 & 0.5 \\
\hline 30.53 & Silt & 8 & 8 & 4 & 0.5 \\
\hline 33.60 & Sandy silt & 8 & 8 & 4 & 0.5 \\
\hline 36.17 & Sandy silt till & 34 & 34 & 16 & 0.5 \\
\hline
\end{tabular}

(7) Birchmount Station

Table A3.12 Summary of the corrected SPT-N values and ratios of $\frac{\left(N_{1}\right)_{60}}{N_{F}}$ for Birchmount Station Borehole BM01 - PMT

\begin{tabular}{|c|c|c|c|c|c|}
\hline Depth (m) & Soil types & $\begin{array}{c}\text { Field measured } \\
\text { SPT-N }\end{array}$ & $N_{F}$ & $\left(N_{1}\right)_{60}$ & Ratio $\frac{\left(N_{1}\right)_{60}}{N_{F}}$ \\
\hline 3.78 & Sandy silt till & 46 & 46 & 38 & 0.8 \\
\hline 6.55 & Sandy silt till & $86 / 275 \mathrm{~mm}$ & 95 & 79 & 0.8 \\
\hline 8.99 & Sandy silt till & $53 / 150 \mathrm{~mm}$ & 108 & 80 & 0.7 \\
\hline 11.94 & Clayey silt till & $50 / 100 \mathrm{~mm}$ & 153 & 106 & 0.7 \\
\hline 15.06 & Sandy silt till & $51 / 150 \mathrm{~mm}$ & 104 & 66 & 0.6 \\
\hline 18.14 & Sandy silt till & $54 / 150 \mathrm{~mm}$ & 110 & 64 & 0.6 \\
\hline
\end{tabular}




\begin{tabular}{|c|c|c|c|c|c|}
\hline 21.34 & Sandy silt/Sand & $72 / 150 \mathrm{~mm}$ & 146 & 80 & 0.6 \\
\hline 24.41 & Sandy silt & $61 / 150 \mathrm{~mm}$ & 124 & 64 & 0.5 \\
\hline 27.69 & Silt & $50 / 75 \mathrm{~mm}$ & 203 & 98 & 0.5 \\
\hline
\end{tabular}

(8) Caledonia Station

Table A3.13 Summary of the corrected SPT-N values and ratios of $\frac{\left(N_{1}\right)_{60}}{N_{F}}$ for Caledonia Station Borehole CA203 - PMT

\begin{tabular}{|c|c|c|c|c|c|}
\hline Depth (m) & Soil types & $\begin{array}{l}\text { Field measured } \\
\qquad \text { SPT-N }\end{array}$ & $\mathrm{N}_{\mathrm{F}}$ & $\left(N_{1}\right)_{60}$ & Ratio $\frac{\left(N_{1}\right)_{60}}{N_{F}}$ \\
\hline 3.91 & Sand and gravel fill & 18 & 18 & 15 & 0.8 \\
\hline 6.76 & Clayey silt fill & 4 & 4 & 3 & 0.8 \\
\hline 9.37 & Silty clay fill & 10 & 10 & 7 & 0.7 \\
\hline 12.14 & Silty sand & 38 & 38 & 26 & 0.7 \\
\hline 15.34 & Sand & 27 & 27 & 17 & 0.6 \\
\hline 18.44 & \multirow{4}{*}{$\begin{array}{l}\text { Silty sand, silt to sandy } \\
\text { silt }\end{array}$} & 86 & 86 & 51 & 0.6 \\
\hline 21.59 & & 67 & 67 & 38 & 0.6 \\
\hline 24.64 & & 46 & 46 & 25 & 0.5 \\
\hline 27.71 & & 52 & 52 & 27 & 0.5 \\
\hline 30.68 & \multirow[t]{4}{*}{ Silty clay } & 31 & 31 & 15 & 0.5 \\
\hline 33.68 & & 25 & 25 & 12 & 0.5 \\
\hline 36.75 & & 20 & 20 & 9 & 0.5 \\
\hline 39.88 & & 40 & 40 & 18 & 0.5 \\
\hline
\end{tabular}

Table A3.14 Summary of the corrected SPT-N values and ratios of $\frac{\left(N_{1}\right)_{60}}{N_{F}}$ for Caledonia Station Borehole CA205A - PMT 


\begin{tabular}{|c|c|c|c|c|c|}
\hline Depth (m) & Soil types & $\begin{array}{c}\text { Field measured } \\
\text { SPT-N }\end{array}$ & $\mathrm{N}_{\mathrm{F}}$ & $\left(N_{1}\right)_{60}$ & Ratio $\frac{\left(N_{1}\right)_{60}}{N_{F}}$ \\
\hline 4.01 & Silty clay fill & 03 & 3 & 3 & 1.0 \\
\hline 5.74 & Silty clay fill & 06 & 6 & 5 & 0.8 \\
\hline 8.92 & Silty clay fill & 09 & 9 & 7 & 0.8 \\
\hline 11.79 & Silty sand & 55 & 55 & 40 & 0.7 \\
\hline 14.86 & Silty sand & $85 / 250 \mathrm{~mm}$ & 104 & 70 & 0.7 \\
\hline 19.30 & Sandy silt & $50 / 100 \mathrm{~mm}$ & 153 & 91 & 0.6 \\
\hline 21.82 & Sandy silt & 85 & 85 & 48 & 0.6 \\
\hline 24.77 & Silty sand & 52 & 52 & 28 & 0.5 \\
\hline 27.89 & Silty sand & 58 & 58 & 30 & 0.5 \\
\hline 30.89 & Silty clay & 38 & 38 & 19 & 0.5 \\
\hline 33.68 & Silty clay & 17 & 17 & 8 & 0.5 \\
\hline 36.81 & Silty clay & 16 & 16 & 7 & 0.4 \\
\hline
\end{tabular}

(9) Don Mills Station

Table A3.15 Summary of the corrected SPT-N values and ratios of $\frac{\left(N_{1}\right)_{60}}{N_{F}}$ for Don Mills Station Borehole DM06 - PMT

\begin{tabular}{|c|c|c|c|c|c|}
\hline Depth $(\mathrm{m})$ & Soil types & $\begin{array}{c}\text { Field measured } \\
\text { SPT-N }\end{array}$ & $\mathrm{N}_{\mathrm{F}}$ & $\left(N_{1}\right)_{60}$ & Ratio $\frac{\left(N_{1}\right)_{60}}{N_{F}}$ \\
\hline 4.22 & Silty clay till & $50 / 100 \mathrm{~mm}$ & 153 & 174 & 1.1 \\
\hline 7.92 & Silty clay & 42 & 42 & 40 & 1.0 \\
\hline 9.42 & Silty clay & 35 & 35 & 31 & 0.9 \\
\hline 11.91 & Sand & 66 & 66 & 56 & 0.9 \\
\hline 14.99 & Sand & 54 & 54 & 41 & 0.8 \\
\hline 17.58 & Silty clay & 27 & 27 & 19 & 0.7 \\
\hline 21.01 & Silty clay & 32 & 32 & 21 & 0.7 \\
\hline 24.44 & Silty clay & 28 & 28 & 17 & 0.6 \\
\hline
\end{tabular}




\begin{tabular}{|l|l|l|l|l|l|}
\hline 27.58 & Silty clay & 30 & 30 & 17 & 0.6 \\
\hline 30.18 & Silty clay & 28 & 28 & 16 & 0.6 \\
\hline
\end{tabular}

(10) Kennedy Station

Table A3.16 Summary of the corrected SPT-N values and ratios of $\frac{\left(N_{1}\right)_{60}}{N_{F}}$ for Kennedy Station Borehole BH7 - PMT

\begin{tabular}{|c|c|c|c|c|c|}
\hline Depth (m) & Soil types & $\begin{array}{c}\text { Field measured } \\
\text { SPT-N }\end{array}$ & $\mathrm{N}_{\mathrm{F}}$ & $\left(N_{1}\right)_{60}$ & Ratio $\frac{\left(N_{1}\right)_{60}}{N_{F}}$ \\
\hline 4.11 & Sandy silt till & Disturbed & - & - & - \\
\hline 6.65 & Sandy silt till & $93 / 275 \mathrm{~mm}$ & 103 & 79 & 0.8 \\
\hline 9.80 & Silty sand till & 46 & 46 & 29 & 0.6 \\
\hline 12.07 & Silty sand & $127 / 200 \mathrm{~mm}$ & 194 & 116 & 0.6 \\
\hline 15.52 & Clayey silt & $115 / 250 \mathrm{~mm}$ & 140 & 78 & 0.6 \\
\hline 19.2 & Silt & $123 / 200 \mathrm{~mm}$ & 188 & 98 & 0.5 \\
\hline 21.39 & Silty clay & 59 & 59 & 30 & 0.5 \\
\hline 24.79 & Silty sand & 79 & 79 & 38 & 0.5 \\
\hline 27.74 & Sand & $50 / 125 \mathrm{~mm}$ & 122 & 57 & 0.5 \\
\hline 30.89 & Silty sand & $50 / 100 \mathrm{~mm}$ & 153 & 69 & 0.5 \\
\hline
\end{tabular}

(11) Lesile Station

Table A3.17 Summary of the corrected SPT-N values and ratios of $\frac{\left(N_{1}\right)_{60}}{N_{F}}$ for Lesile Station Borehole LE02 - PMT 


\begin{tabular}{|c|c|c|c|c|c|}
\hline Depth (m) & Soil types & $\begin{array}{c}\text { Field measured } \\
\text { SPT-N }\end{array}$ & $\mathrm{N}_{\mathrm{F}}$ & $\left(N_{1}\right)_{60}$ & Ratio $\frac{\left(N_{1}\right)_{60}}{N_{F}}$ \\
\hline 3.51 & Silty clay (Fill) & 9 & 9 & 8 & 0.9 \\
\hline 6.40 & Silty clay (Fill) & 8 & 8 & 7 & 0.9 \\
\hline 12.9 & Silty clay & 25 & 25 & 16 & 0.6 \\
\hline 15.7 & Silty clay & 24 & 24 & 14 & 0.6 \\
\hline 18.75 & Silty clay & 35 & 35 & 18 & 0.5 \\
\hline 21.79 & Silty clay & 43 & 43 & 21 & 0.5 \\
\hline 24.84 & Silty sand & $93 / 250 \mathrm{~mm}$ & 114 & 54 & 0.5 \\
\hline 27.89 & Sand & $50 / 125 \mathrm{~mm}$ & 122 & 56 & 0.5 \\
\hline 30.94 & Sand & $98 / 250 \mathrm{~mm}$ & 120 & 53 & 0.4 \\
\hline
\end{tabular}

(12) Mount Dennis Station

Table A3.18 Summary of the corrected SPT-N values and ratios of $\frac{\left(N_{1}\right)_{60}}{N_{F}}$ for Mount Dennis Station Borehole MD101 - PMT (i.e MD 101C1)

\begin{tabular}{|c|c|c|c|c|c|}
\hline Depth $(\mathrm{m})$ & Soil types & $\begin{array}{c}\text { Field measured } \\
\text { SPT-N }\end{array}$ & $\mathrm{N}_{\mathrm{F}}$ & $\left(N_{1}\right)_{60}$ & Ratio $\frac{\left(N_{1}\right)_{60}}{N_{F}}$ \\
\hline 3.8 & Sand & 33 & 33 & 27 & 0.8 \\
\hline 6.0 & Sand & 35 & 35 & 30 & 0.9 \\
\hline 9.4 & Sand silt & 43 & 43 & 35 & 0.8 \\
\hline 13.9 & Sand silt & 25 & 25 & 18 & 0.7 \\
\hline 15.2 & Sand silt & 39 & 39 & 28 & 0.7 \\
\hline 18.3 & Sand silt & 26 & 26 & 17 & 0.7 \\
\hline 21.3 & Sand & 12 & 51 & 31 & 0.6 \\
\hline 24.5 & Silty clay & 29 & 29 & 16 & 0.6 \\
\hline 27.3 & Clayey silt till & 45 & 45 & 23 & 0.5 \\
\hline 30.4 & Clayey silt till & 38 & 38 & 19 & 0.5 \\
\hline 35 & Silty clay & & & & 0.6 \\
\hline
\end{tabular}


(13) Victoria Station

Table A3.19 Summary of the corrected SPT-N values and ratios of $\frac{\left(N_{1}\right)_{60}}{N_{F}}$ for Victoria Station Borehole VP01 - PMT

\begin{tabular}{|c|c|c|c|c|c|}
\hline Depth (m) & Soil types & $\begin{array}{c}\text { Field measured } \\
\text { SPT-N }\end{array}$ & $\mathrm{N}_{\mathrm{F}}$ & $\left(N_{1}\right)_{60}$ & Ratio $\frac{\left(N_{1}\right)_{60}}{N_{F}}$ \\
\hline 4.37 & Silty clay till & 37 & 37 & 31 & 0.8 \\
\hline 6.83 & Clayey silt till & 14 & 14 & 11 & 0.8 \\
\hline 9.83 & Clayey silt till & 24 & 24 & 15 & 0.6 \\
\hline 13.61 & Sand & 21 & 21 & 13 & 0.6 \\
\hline 16.18 & Silt & 123 & 123 & 69 & 0.6 \\
\hline 19.46 & Silt & $79 / 150 \mathrm{~mm}$ & 161 & 85 & 0.5 \\
\hline 22.25 & Silt & 70 & 70 & 35 & 0.5 \\
\hline 25.86 & Silt & 15 & 15 & 7 & 0.5 \\
\hline 28.88 & Silt & 92 & 92 & 42 & 0.5 \\
\hline 31.06 & Silt & 34 & 34 & 15 & 0.4 \\
\hline 35 & Silt & 88 & 88 & 37 & 0.4 \\
\hline
\end{tabular}

(14) Warden Station

Table A3.20 Summary of the corrected SPT-N values and ratios of $\frac{\left(N_{1}\right)_{60}}{N_{F}}$ for Warden Station Borehole WA04 - PMT

\begin{tabular}{|c|c|c|c|c|c|}
\hline Depth (m) & Soil types & $\begin{array}{c}\text { Field measured } \\
\text { SPT-N }\end{array}$ & $\mathrm{N}_{\mathrm{F}}$ & $\left(N_{1}\right)_{60}$ & Ratio $\frac{\left(N_{1}\right)_{60}}{N_{F}}$ \\
\hline 3.63 & Silty clay till & 29 & 29 & 22 & 0.8 \\
\hline 5.82 & Silty clay till & 17 & 17 & 13 & 0.8 \\
\hline 8.97 & Gravelly sand & 23 & 23 & 17 & 0.7 \\
\hline
\end{tabular}




\begin{tabular}{|c|c|c|c|c|c|}
\hline 11.71 & Silty clay till & $53 / 150 \mathrm{~mm}$ & 108 & 74 & 0.7 \\
\hline 15.67 & Sandy silt till & $50 / 75 \mathrm{~mm}$ & 203 & 126 & 0.6 \\
\hline 18.44 & Silty sand & $86 / 250 \mathrm{~mm}$ & 105 & 61 & 0.6 \\
\hline 21.01 & Sandy silt & $50 / 100 \mathrm{~mm}$ & 153 & 85 & 0.6 \\
\hline 24.08 & Silt & $50 / 100 \mathrm{~mm}$ & 153 & 80 & 0.5 \\
\hline 27.03 & Silty sand & $50 / 75 \mathrm{~mm}$ & 203 & 102 & 0.5 \\
\hline 30.3 & Silty sand & $50 / 125 \mathrm{~mm}$ & 122 & 58 & 0.5 \\
\hline
\end{tabular}

(15) West Portal Station

Table A3.21 Summary of the corrected SPT-N values and ratios of $\frac{\left(N_{1}\right)_{60}}{N_{F}}$ for West Portal Station Borehole C3 - PMT

\begin{tabular}{|c|c|c|c|c|c|}
\hline Depth (m) & Soil types & $\begin{array}{c}\text { Field measured } \\
\text { SPT-N }\end{array}$ & $\mathrm{N}_{\mathrm{F}}$ & $\left(N_{1}\right)_{60}$ & Ratio $\frac{\left(N_{1}\right)_{60}}{N_{F}}$ \\
\hline 1.7 & Sand to silty sand fill & 28 & 28 & 32 & 1.1 \\
\hline 3.84 & Sand to silty sand fill & 32 & 32 & 24 & 0.8 \\
\hline 9.19 & Sandy silt & 06 & 06 & 4 & 0.7 \\
\hline 13.77 & Silty clay till & 15 & 15 & 9 & 0.6 \\
\hline 15.42 & Silty clay till & 05 & 05 & 3 & 0.6 \\
\hline
\end{tabular}

(16) Wynford Station

Table A3.22 Summary of the corrected SPT-N values and ratios of $\frac{\left(N_{1}\right)_{60}}{N_{F}}$ for Wynford Station Borehole WY03 - PMT 


\begin{tabular}{|c|c|c|c|c|c|}
\hline Depth $(\mathrm{m})$ & Soil types & $\begin{array}{c}\text { Field measured } \\
\text { SPT-N }\end{array}$ & $\mathrm{N}_{\mathrm{F}}$ & $\left(N_{1}\right)_{60}$ & Ratio $\frac{\left(N_{1}\right)_{60}}{N_{F}}$ \\
\hline 3.68 & Silty clay till & 28 & 28 & 21 & 0.8 \\
\hline 5.84 & Silty clay till & 23 & 23 & 17 & 0.7 \\
\hline 8.79 & Silty clay & 10 & 10 & 7 & 0.7 \\
\hline 12.14 & Clayey silt till & 32 & 32 & 19 & 0.6 \\
\hline 14.71 & Silty clay & $83 / 275 \mathrm{~mm}$ & 92 & 52 & 0.6 \\
\hline 18.14 & Silty clay till & $50 / 125 \mathrm{~mm}$ & 122 & 64 & 0.5 \\
\hline 20.88 & Silty clay till & $50 / 250 \mathrm{~mm}$ & 61 & 31 & 0.5 \\
\hline 24.38 & Silty sand & $50 / 100 \mathrm{~mm}$ & 153 & 73 & 0.5 \\
\hline 27.64 & Silty sand & $50 / 100 \mathrm{~mm}$ & 153 & 70 & 0.5 \\
\hline 30.2 & Inferred sandy soil & $50 / 100 \mathrm{~mm}$ & 153 & 67 & 0.4 \\
\hline
\end{tabular}


APPENDIX 4.1

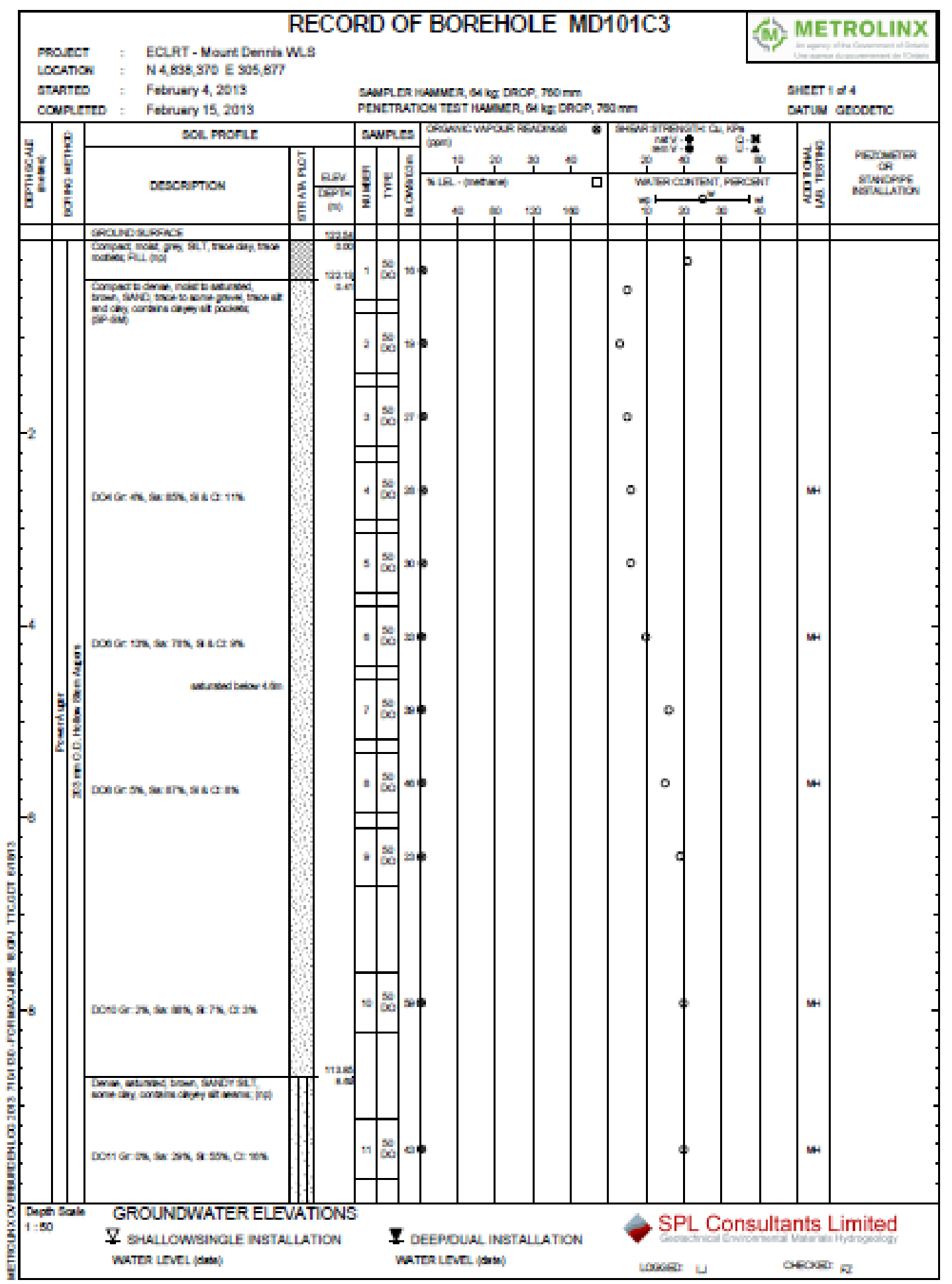




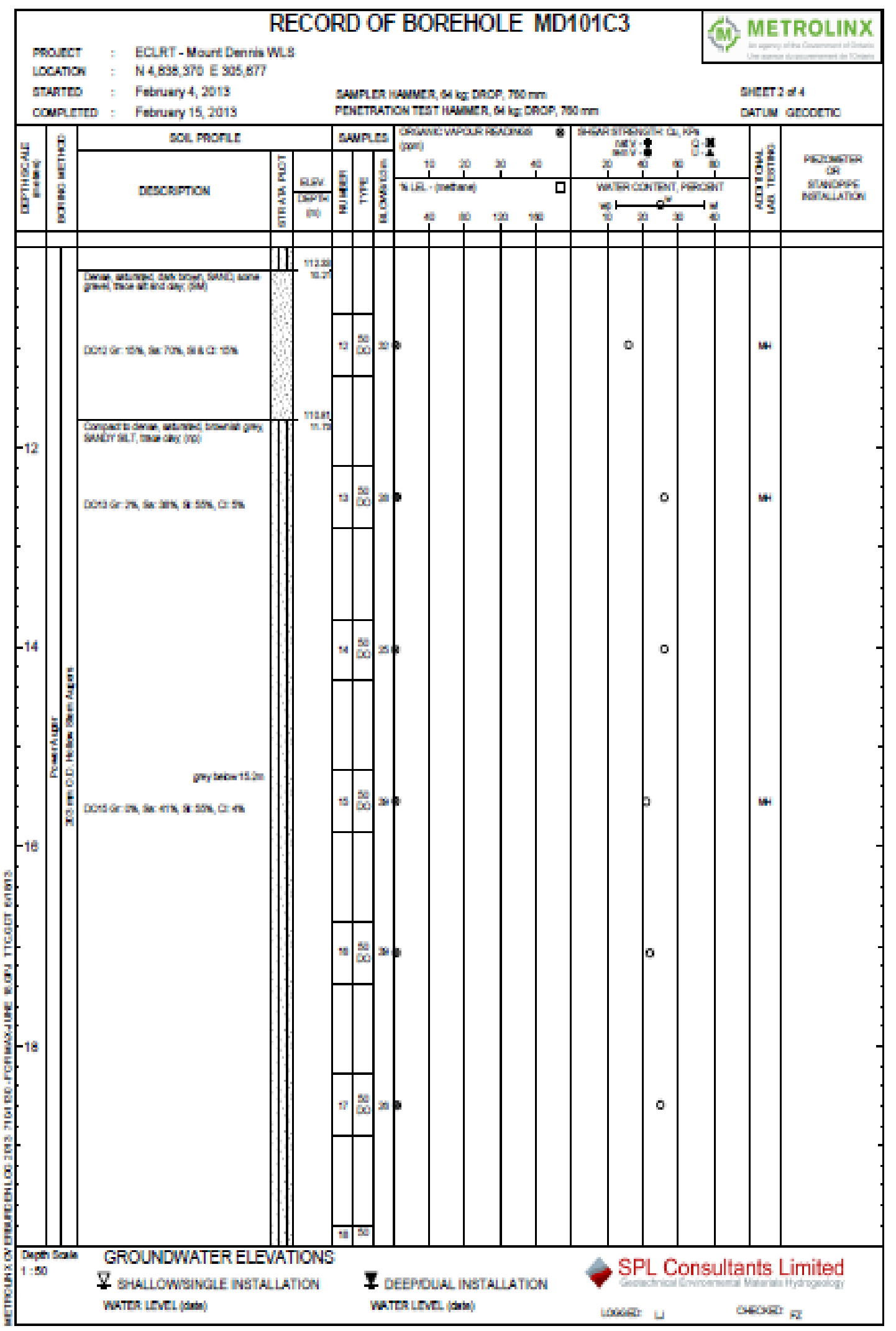




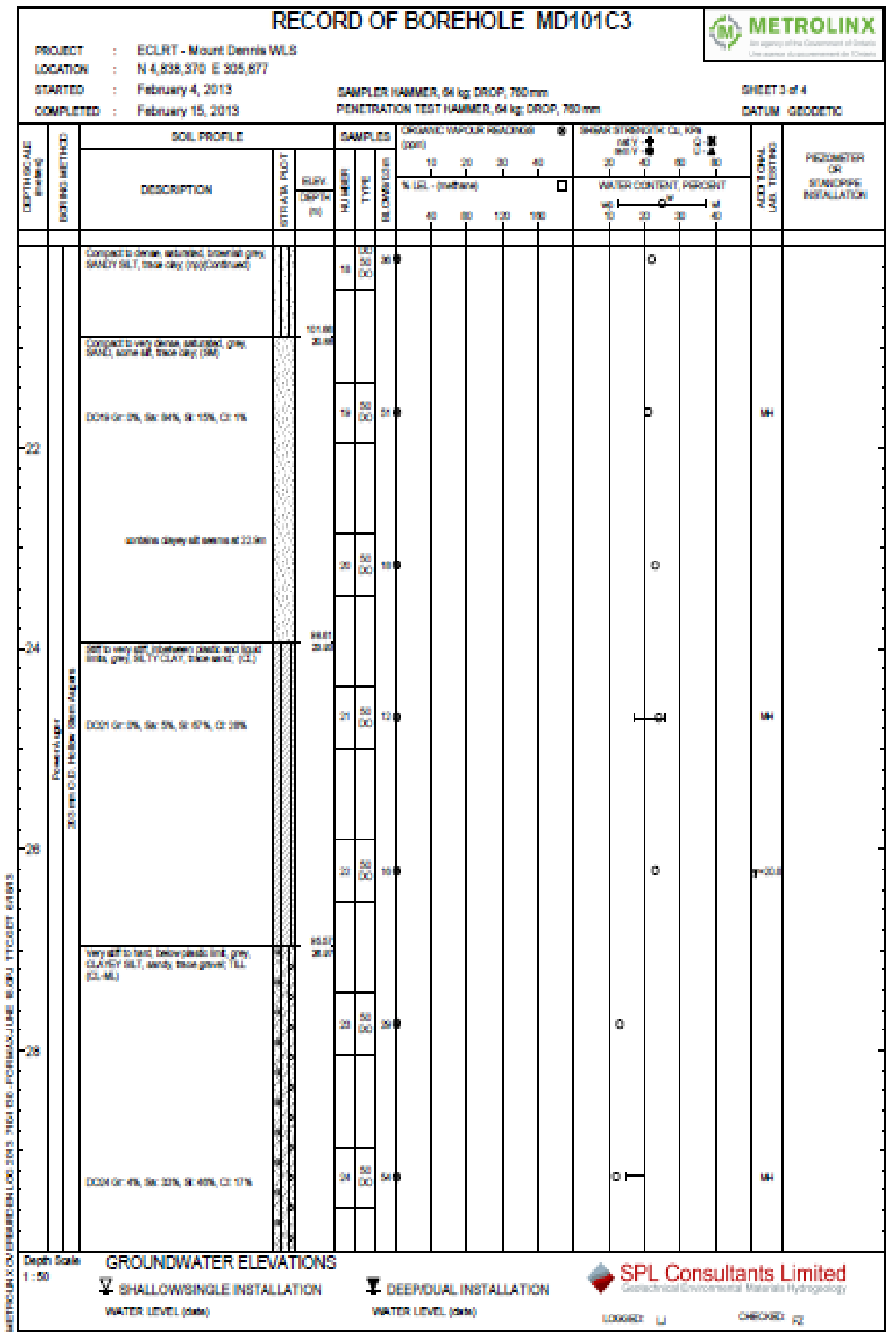




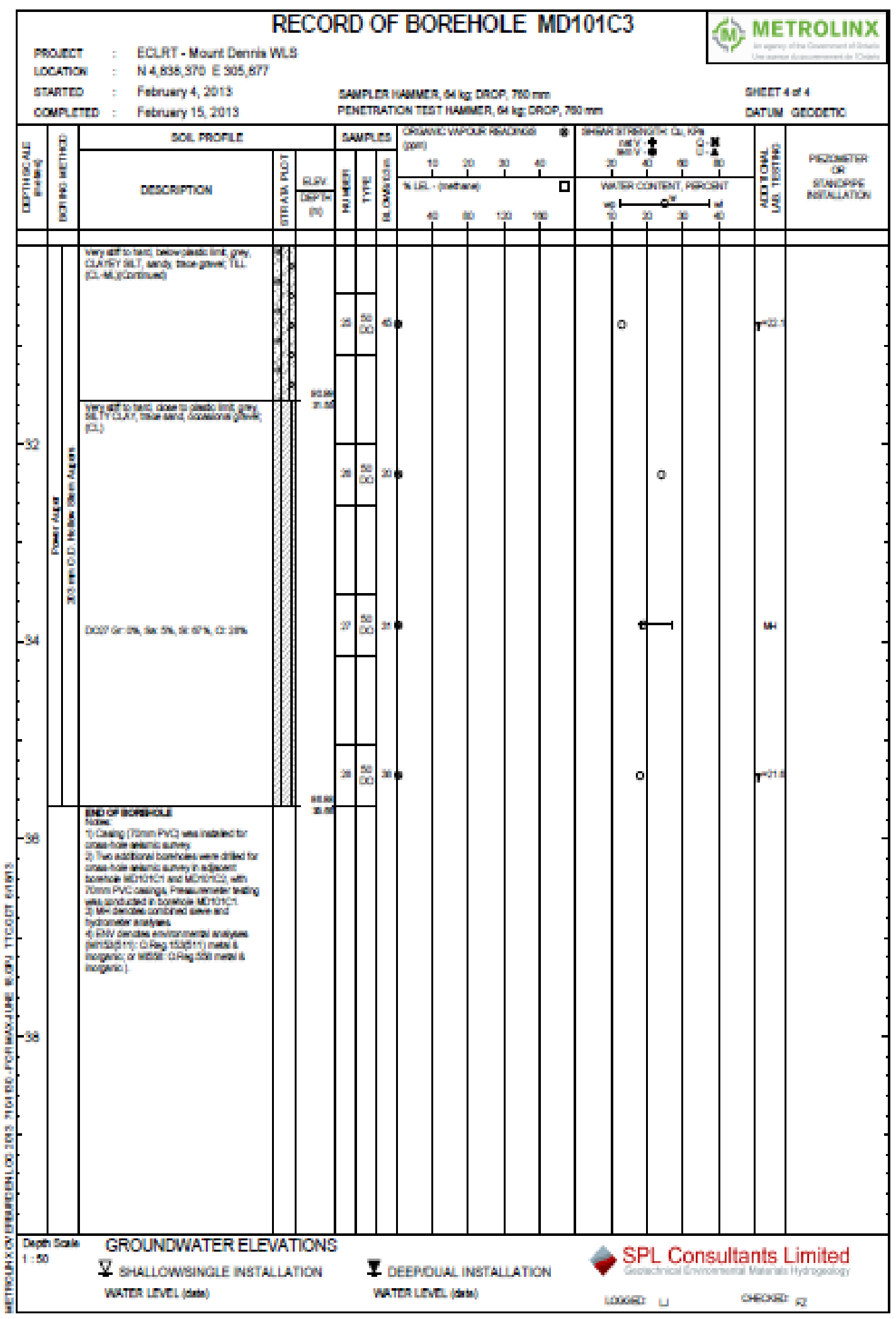




\section{APPENDIX 4.2}

Table D1: Summary of Pressuremeter Test Results from Borehole MD101-PMT (i.e. MD101C1)

\begin{tabular}{|c|c|c|c|c|c|c|c|c|}
\hline $\begin{array}{l}\text { Test } \\
\text { No. }\end{array}$ & $\begin{array}{l}\text { Test } \\
\text { Depth } \\
\text { (m) }\end{array}$ & $\begin{array}{l}\text { Test } \\
\text { Elev. } \\
\text { (m) }\end{array}$ & Soil Type* & $\begin{array}{c}\mathrm{E}_{\mathrm{PMT}} \\
(\mathrm{MPa})\end{array}$ & $\begin{array}{l}\mathbf{E}_{\text {Unlosd 1 }} \\
\text { (MPa) }\end{array}$ & $\begin{array}{l}\mathbf{E}_{\text {Reload 1 }} \\
\text { (MPa) }\end{array}$ & $\begin{array}{c}\mathrm{Py} \\
(\mathrm{kPa})\end{array}$ & $\mathrm{p}_{\mathrm{L}}{ }_{\mathrm{L}}(\mathrm{kPa})$ \\
\hline 1 & 3.8 & 118.7 & Sand & 0.2 & 0.6 & 0.6 & 84 & 214 \\
\hline 2 & 6.0 & 116.5 & Sand & 25.8 & 160.4 & 9.1 & 989 & 2421 \\
\hline 3 & 9.4 & 113.1 & Sandy silt & 40.8 & 159.1 & 67.0 & 582 & 2735 \\
\hline 4 & 13.9 & 108.6 & Sandy silt & 38.6 & 209.7 & 100.4 & 700 & 3126 \\
\hline 5 & 15.2 & 107.3 & Sandy silt & 27.8 & 151.5 & 68.5 & 596 & 2657 \\
\hline 6 & 18.3 & 104.2 & Sandy silt & 28.9 & 139.6 & 58.2 & 533 & 1940 \\
\hline 7 & 21.3 & 101.2 & Sand & 29.1 & 125.2 & 63.6 & 638 & 2428 \\
\hline 8 & 24.5 & 98.0 & Silty clay & 36.2 & 116.0 & 45.0 & 676 & 1520 \\
\hline 9 & 27.3 & 95.2 & Clayey silt till & 46.2 & 140.0 & 65.5 & 789 & 994 \\
\hline 10 & 30.4 & 92.1 & Clayey silt till & 53.9 & 148.5 & 83.4 & 1063 & 1110 \\
\hline 11 & 35.0 & 87.5 & Silty clay & 22.7 & 145.2 & 97.9 & 786 & 1373 \\
\hline
\end{tabular}

Notes: * Soil type is based on the information in adjacent Borehole MD101C3. 